\title{
Eliseo Collazos Fog Water Farm-Park and Gardens Methods
}

\author{
Research Fellow: \\ Leann Andrews, PhD, RLA \\ Affiliate Assistant Professor, University of Washington \\ Project Manager, Traction \\ Research Assistant: \\ Rebecca Bachman \\ MLA and Global Health Cert. 2020 \\ University of Washington \\ Firm Liaison: \\ Coco Alarcón, MLA, Arq. \\ PhD Candidate, Implementation Science, University of Washington \\ Project Manager, Traction
}

This investigation was conducted as part of the Landscape Architecture Foundation's 2020 Case Study Investigation (CSI) program. CSI matches faculty-student research teams with design practitioners to document the benefits of exemplary high-performing landscape projects. Teams develop methods to quantify environmental, social, and economic benefits and produce Case Study Briefs for LAF's Landscape Performance Series.

To cite:

Andrews, Leann, and Rebecca Bachman. "Eliseo Collazos Fog Water Farm-Park and Gardens Methods." Landscape Performance Series, Landscape Architecture Foundation, 2020.

https://doi.org/10.31353/cs1631

The full case study can be found at: https://landscapeperformance.org/case-study-briefs/eliseocollazos 


\section{Acknowledgements}

Thank you to Ben Spencer at Traction for help with budget information, Jess Smith at Traction for water calculations, and Coco Alarcón at Traction for materials cost calculations.

\section{Table of Contents}

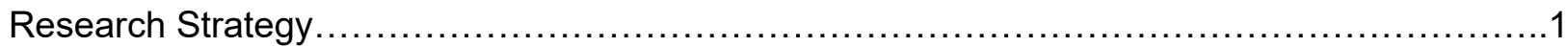

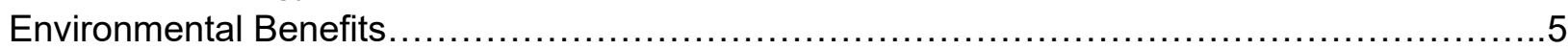

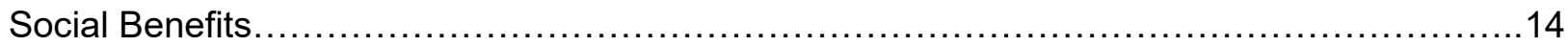

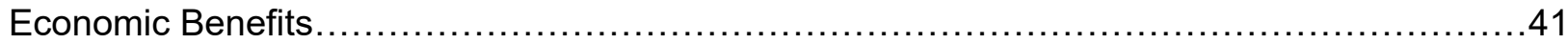

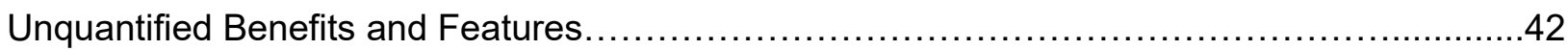

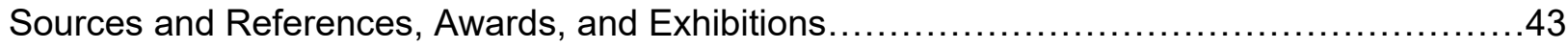

\section{Appendices 1-3: Research Instruments}

Appendix 1: Participatory Impact Assessment (PIA) Post Project Evaluation Questionnaire ....46 Appendix 2: Mental Health and Quality of Life Questionnaire with WHO Scoring Instructions...57

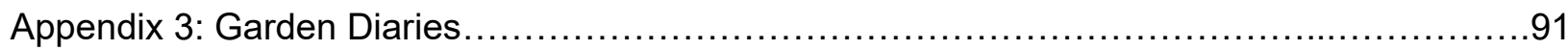

\section{Appendices 4-6: Construction and Maintenance Manuals}

Appendix 4: Household Gardens Maintenance Manual......................................94

Appendix 5: Fog Collectors Maintenance Manual.......................................115

Appendix 6: Fog System and Farm Park Maintenance Manual.............................129

\section{Appendices 7-8: Project Images}

Appendix 7: Project Overview in Images

\section{Research Strategy}

Research on landscape performance was embedded in the project from the very start and is also integral to Traction's firm methodology. The Fog Water Farm-Park and Gardens project used a variety of complementary research methods before, after, and throughout project implementation phases. These methods were triangulated in this study in order to best understand project impacts. For example, to understand the impact the project had on food insecurity, the team compiled data from a) field counts of productive plants over time, b) Garden Diaries that documented produce harvested, and c) a question on the Participatory Impact Assessment (PIA) asking about how the project impacted food insecurity in their family. The infrastructure at Eliseo Collazos was implemented in the following phases: 
Phase 1 (2013): 29 home gardens

Phase 2 (2015): 31 additional home gardens and 4 fog collectors

Phase 3 (2016): Farm-park, cisterns, and 2 fog collectors

Phase 4 (2017): Pocket park

See Figure 1 (pg. 4) for a complete timeline of the research and design activities including implementation. The complementary research methods used as part of the project include:

1) PIA Survey-Participatory Impact Assessments (PIAs) were critical to the participatory aspect of the project. Residents defined their own indicators of project success in the very beginning of the design process, which were then revisited in the form of quantitative post-project implementation PIA surveys to evaluate the extent to which the project met community-identified goals. A baseline PIA was conducted one month before the project and the post-project PIA was conducted 6 months after construction. PIAs were conducted verbally and on paper at community meetings, and one adult representative from each family in the community was invited to participate. Emphasis on data collected via PIAs throughout this case study highlights the importance of centering community members and their identified priorities and needs at every stage of the Fog Water Farm-Park and Gardens project. The PIA process also helped to shape the other research instruments used in the project, described below. See Appendix 1 for a copy of the PIA survey.

2) Health assessment-A team of nurses and public health researchers verbally implemented a quantitative quality of life survey that utilized several validated scales (WHO Quality of Life-Brief Version, Perceived Stress Scale, Life-Threatening Experiences Scale, Parent/Partner Empathy Scale) to understand mental and social health two weeks before the project began, and again six months and one year after the construction of the first phase of the project. This health survey was conducted alongside anthropometric (physical) measures conducted by nurses including blood pressure, weight, height, arm/waist/hip circumference, and glucose. Both the health survey and anthropometric measures were conducted house-by-house on one adult per family and open to all 82 families who lived in Eliseo Collazos in 2013. The survey and anthropometric measures captured 44 adults, 29 of which participated in Phase I of the project, the first phase of household gardens. The team piloted the survey with residents who did not ultimately participate in the survey to test for cultural appropriateness and comprehension and adjusted the instrument language accordingly. The team also held qualitative focus group discussions to understand the context of the health survey responses and anthropometric measures and the relationships between design interventions and health. See Appendix 2 for a copy of the survey with WHO scoring instructions. See Korn et al, 2018 for a detailed methods.

3) Garden Diaries-Garden Diaries were another method employed to document the use, productivity, and burden of the home gardens on individual households. The Garden 
Diaries were a highly pictorial questionnaire given to each family who participated in Phase I of the household gardens project to fill out each week after construction over a total of 14 weeks from September to December. Of the 29 households that participated in Phase I of the household gardens project, 26 participated in Garden Diaries. See Appendix 3 for a copy of the Garden Diaries.

4) Plant Counts-Quantitative plant counts (plant species and quantities) were conducted over time by members of the research team trained to identify local plants in both the community farm-park and home gardens. Plant counts measure garden changes, community investment (plants that the project contributed vs. plants the residents planted themselves), and signs of project stewardship. For the 29 Phase I household gardens $(n=29)$, plant counts were conducted at participating houses 2 weeks before project implementation, immediately after implementation, 6 months later, 1 year later, and 3.5 years later. For the Phase II household gardens $(n=31)$, plant counts were conducted at participating houses 2 weeks before project implementation, immediately after implementation and 1.5 years later. For Phase III, which consisted of the community farm-park and fog collectors, plant counts were conducted at the terraced farm park immediately after implementation and 6 months later.

5) Fog collector performance-The team took several environmental field measures over the course of the project. Systematic quantitative methods were used on-site and in a controlled laboratory to evaluate weather conditions and efficiency of different materials, elevations, and positions of the fog collectors over the course of the foggy season. See Feld et al, 2016 for detailed methods.

6) Photo documentation-The team conducted systematic qualitative photo documentation of the home gardens to capture the appearance and changes of the home gardens and houses over time. The documentation includes photographs at each of the houses that participated in the household gardens. Photos were taken at houses who participated in Phase I of the household gardens $(n=29)$ at 2 weeks before project implementation, immediately after construction, after 6 months, after 1.5 years, and after 3.5 years. Photos were taken at houses that participated in Phase II of the household gardens $(n=31) 2$ weeks before project implementation, immediately after construction, and after 1.5 years. See Appendix 8 for an example of images showing the evolution of a Phase I household garden over the span of 7 years. 


\section{PIA SURVEY}

Quantitative participatory impac ssessment (PIA) by community

\section{HEALTH ASSESSMENT}

2. Quantitative mental + socia

measures by nurses

3. GARDEN DIARIES

3. Quantitative household illustrated

survey by community

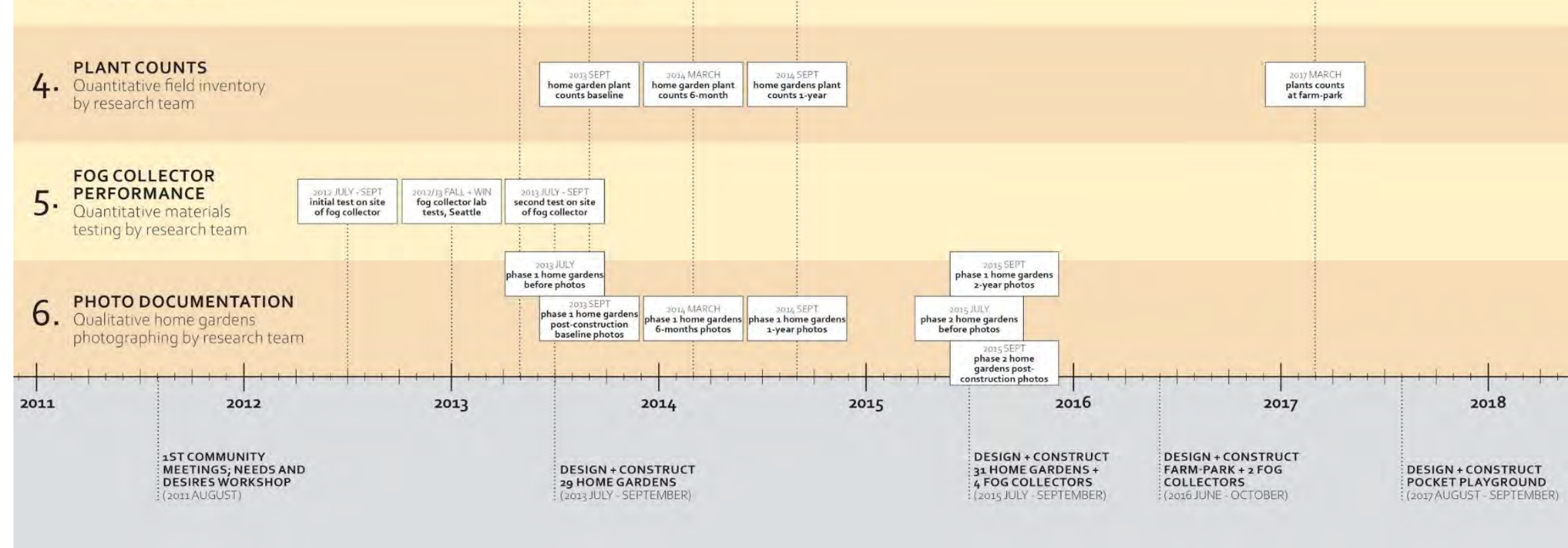

Figure 1: Timeline of project research and design activities 


\section{Environmental Benefits}

- Collects 90,000 liters (23,789 gallons) of water per month during the foggy season, fulfilling $100 \%$ of home garden irrigation needs while improving satisfaction with access to water among $74 \%$ of 23 surveyed household representatives. This saves the community as a whole from 2,424 soles ( $\$ 680$ USD) to 13,200 soles $(\$ 3,700$ USD) per month depending on the season.

Background: Eliseo Collazos is located in a coastal desert ecosystem called the lomas (term for the rolling hills at the base of the Andes Mountains) or "fog oases," an area that receives less than $10 \mathrm{~mm}$ of rainfall annually. Urbanization and illegal mining and agriculture practices have degraded the ecosystem, resulting in a lack of the delicate fog-fed greenery for which the pristine lomas is known. The region experiences dense fog spanning winter months, roughly May through December. This fog results from the convergence of the Peru (Humboldt) Current and the Pacific anticyclone, which produces the low layer of stratus clouds that blankets the Lima metropolitan area for six to nine months out of the year (Feld et al, 2016). Fog is particularly dense where clouds meet the hills surrounding Lima, providing the opportunity for simple yet innovative place-based technology to harvest and redirect moisture toward irrigation for nourishing, ecologically restorative green space (Heileman et al, 2009).

In community workshops, residents of Eliseo Collazos identified water insecurity and access to green space as top priorities, by first identifying individual needs and then voting and negotiating top priorities as a community during the workshop. In 2012, when these priorities were established through community meetings, the community had recently collectively paid the municipality to get a small-diameter water pipe to run up to two community taps from the municipality below.

70 out of the 82 households in Eliseo Collazos were contributing 10 soles per month per house to a community fund for this municipal water. Of the 700 soles collected each month, about 450 soles went toward paying for the water and about 250 soles went toward other water- and sanitation-related expenses such as a garden hose used to get water from taps to 200-liter and 500 -liter containers at people's homes and to pay the person who distributes water using this hose. Households that did not opt into this system for any number of reasons, such as the hose not reaching their house, working or staying in the city for long periods of time rendering their water usage at home too low to justify the cost, or an inability to afford the community system, would obtain water elsewhere.

The municipal water only flowed for a few hours each day and could fill only about 10 households' water containers each day. Because this municipal water system was insufficient to meet the household and drinking water needs of all of the households in Eliseo Collazos, households had designated water days and hours and had to supplement with other water the rest of the time. The piped-in municipal water was affordable at approximately 1.4 soles per 200 
liters (\$0.38 USD per 50 gallons), but options for supplementing it were very expensive, as exemplified by the private water trucks that charged about 20 soles per 200 liters (roughly $\$ 6$ USD per 52 gallons). For context, the typical daily family income was 40 to 100 soles (roughly $\$ 11$ to $\$ 28$ USD), and income was collected day-by-day and not regularly (through the informal economy). These issues of access to water led people to reuse water (for example, water used in cooking would be reused for laundry), to limit their hygiene practices, and to drink cheaper liquids like soda for hydration.

The primary design priority of the community was to add green space, and access to water rose to the top of priorities not only to meet household needs but also because of the desire to green the community. The fog water system was designed to collect water to fulfill the latter purpose, but the team intentionally overestimated in calculations in anticipation of a future need to help fulfill the former, especially for families that live out of reach of the pipe-and-hose system. Furthermore, the water system of self-constructed pipes, flexible rubber hose, and individual storage containers presents risk of contamination from the hose being carried around through unsanitary conditions, self-constructed open-piped systems, and water sitting stagnant in unsealed containers for up to a week, as well as the risk of hosting habitat for mosquito proliferation in open containers. The fog-water system is a closed system from sedimentation tank to taps, thus reducing risk of exposure to contamination and water-borne and mosquitoborne infectious diseases in Eliseo Collazos. The increased access to domestic water also promotes hygiene, and community members started washing produce and hands more often.

The fog water system has made Eliseo Collazos more resilient on a number of occasions in which informal communities were deprioritized in extreme regional and global events. In March of 2017, when extreme flooding and mudslides shut down Lima's entire water supply for two weeks, the cisterns still had water from being filled in the previous fog season, and Eliseo Collazos was able to use this water for all domestic needs not requiring potable water. Despite the eventual disconnection of the cisterns from the fog collection system due to mafias and recent settling in the area (along with changing community needs as discussed in the Lessons Learned section), the community was still able to use the cisterns, filling them up to store municipal water at a minimal cost to supply their domestic and greenspace needs. At the beginning of the COVID-19 pandemic in April-May of 2020, which halted supply of food and private water to informal communities at large due to strict shelter-in-place mandates, the cisterns held water that was sufficient to meet household water needs while irrigating an emergency food supply through their productive home gardens.

The water needs of the community increased with the implementation of green spaces, which is an outcome not connected to more waste of water but to better hygiene, less dehydration, and better nutrition. Community meetings and field measures of existing plants by the research team indicate that people very likely would have worked hard to build green spaces and provide water to them regardless of whether an alternative water source had been established through the Fog Water Farm-Park and Gardens project and despite the significant economic burden on their families to obtain or purchase water for irrigation. The fog water storage system has changed the way the community uses water as well as the amount of water available, freeing up more of 
the community's already extremely limited funds for other essentials. Even without the system being connected to the fog collectors, the cisterns provide safer storage for more water than before and have eliminated the proliferation of Aedes aegypti mosquitoes (the vectors for dengue fever, yellow fever, and Zika) in Eliseo Collazos.

Methods: Methods for evaluating water harvesting: 1) fog collection performance field measures and 2) design calculations (method 5 in Methods Overview) and 3) a question included in the post-project PIA (method 1 in Methods Overview):

\section{1) Field measures}

The team conducted lab and field trials of different types of textiles at different elevations and orientations, as well as fog collector configurations to determine which combination of factors was capable of consolidating fog into water at the highest volume over time. Of three elevations tested $(360 \mathrm{~m} / 1,181 \mathrm{ft}, 425 \mathrm{~m} / 1,394 \mathrm{ft}$, and $500 \mathrm{~m} / 1,640 \mathrm{ft})$, volumes collected were highest at $500 \mathrm{~m}$. Of three fabrics tested, Enkamat 7010 fabric was found to be most effective. Through four field tests, the team found the minimum, maximum, and average rates at which Enkamat 7010 fabric condensed fog to water during the foggy season. These values were foundational in calculating all other aspects of the fog water collection system. For more information on the fog collection technology methods and results used in this project, refer to Feld et al, 2016.

\section{2) Fog water collection system design calculations}

The team calculated values for water needs, fog collection yields, and water storage needs to inform the planning and design of the fog collection system. The team worked backwards from a goal of collecting and storing enough water through the foggy season to meet the water needs of a planting area of 200 square meters $(2,152.78 \mathrm{sf}$ ) through the dry (non-foggy) season, in addition to harvesting enough fog water to sustain those areas through the foggy season. The calculations done during this design phase showed that six 5,000-liter cisterns would store the target amount of water. In implementation, however, an additional cistern was installed in the storage system to support potential future needs or changing climatic conditions, bringing the total number of cisterns in the existing fog water collection system to seven. The foggy season and dry (non-foggy) seasons were assumed to span seven months and five months, respectively, to adjust for variation and transition months characterized by lighter fog flanking the six- to nine-month foggy season.

Reflecting the official system of measurement in Peru, the metric system is used in fog water collection system calculations. Quantities that are included as findings in this case study are converted to imperial units at the end of the calculation.

\section{3) Post-project PIA Q3}

The assessment of satisfaction with access to water is derived from a question on a PIA questionnaire conducted roughly six months after the fog water collection system began irrigating green spaces in Eliseo Collazos: "The fog collection and park made access to water..." Responses were on a scale of 1 to 5 , where $1=$ much worse and $5=$ much better. Responses were counted and total participants reporting positive responses (5s and $4 \mathrm{~s}$ ) were added to find 
total participants reporting improvement. 23 out of 23 surveyed household representatives answered the question. Percentages were calculated based on an $n$ value of 23 , representing $28 \%$ of households in Eliseo Collazos when the project started.

Methods for cost savings:

Cost saving estimates were informed by field measures by the research team (method 5 in Methods Overview), photo documentation (method 6 in Methods Overview), and conversations with community residents.

The post-project minimum water needs of the community include drinking and domestic water and the water required to irrigate green spaces. Amounting to approximately $132,000 \mathrm{~L} / \mathrm{month}$ $(34,870.71 \mathrm{gal} / \mathrm{week})$, the estimated cost of meeting these water needs varies depending on the source of water: public piped water, private trucked water, or fog water. Before the Fog Water Farm-Park and Gardens project was implemented, households relied on a combination of public piped water and private trucked water. Using the costs of these water sources, the cost per liter for each was calculated and applied to new water needs which have grown due to growth in the community from 82 households to 90 households as well as through the implementation of green spaces. Because the community would not have been able to implement green spaces without augmented access to water, cost savings are calculated for water needs with and without green spaces.

Calculations:

Water harvesting calculations

Water needs (given information)

- Area of plantings $=200 \mathrm{~m}^{2}=2,152.78 \mathrm{ft}^{2}$

- Plant density $=4$ plants $/ \mathrm{m}^{2}$

- Plant water needs = average of $7.5 \mathrm{~L} / \mathrm{month} /$ plant

Fog collection yields (given information)

- Area of one fog net: $11 \mathrm{~m} * 4 \mathrm{~m}$ triangle $=\left(11^{*} 4\right) / 2=22 \mathrm{~m}^{2}$

- Enkamat 7010 average fog catchment rate (Feld et al, 2016): minimum $1,280 \mathrm{~mL} / \mathrm{m}^{2} / \mathrm{hr}$; maximum $1,895 \mathrm{~mL} / \mathrm{m}^{2} / \mathrm{hr}$; average $=(1,280+1,895) / 2=1,587.5 \mathrm{~mL} / \mathrm{m}^{2} / \mathrm{hr}$

Water storage needs calculations

1. $200 \mathrm{~m}^{2 *} 4$ plants $/ \mathrm{m}^{2}=800$ plants

2. Amount of water needed for planted areas monthly: 800 plants * $7.5 \mathrm{~L} / \mathrm{plant} / \mathrm{month}=$ $6,000 \mathrm{~L} / \mathrm{month}=1,585.032 \mathrm{gal} / \mathrm{month}$, rounded to $1,585 \mathrm{gal} / \mathrm{month}$

3. Amount of water needed for planted areas annually: $6,000 \mathrm{~L} / \mathrm{month} * 12$ months $=$ 72,000 L/year

4. Amount of water needed to collect during the fog season to provide enough for the nonfog season: 5 months of dry season * $6,000 \mathrm{~L} /$ month $=30,000 \mathrm{~L}$

5. Number of $5,000 \mathrm{~L}$ tanks needed to hold $30,000 \mathrm{~L}: 30,000 \mathrm{~L} / 5,000 \mathrm{~L}=6$ tanks

6. Amount of extra water storage: $\left(7\right.$ tanks $\left.{ }^{*} 5,000 \mathrm{~L}\right)=35,000 \mathrm{~L}-30,000 \mathrm{~L}=5,000 \mathrm{~L}$ 
Water collection calculations

1. Area of 6 fog nets: $6^{*} 22 \mathrm{~m}^{2}=132 \mathrm{~m}^{2}=1420.84 \mathrm{ft}^{2}$

2. Hourly maximum fog water quantity harvested from all 6 fog collectors: $250,140 \mathrm{~mL} / \mathrm{hr}=$ $250.14 \mathrm{~L} / \mathrm{hr}$

3. Daily maximum fog water quantity harvested (assume 12 hours/day of fog): $250.14 \mathrm{~L} / \mathrm{hr}$ * 12 hours $=3,001.68 \mathrm{~L} /$ day $=792.95996612 \mathrm{gal} / \mathrm{day}$, rounded to $793 \mathrm{gal} / \mathrm{day}$ )

4. Monthly maximum fog water quantity harvested (assume 30 days $/ \mathrm{mo}$ ): $3,001.68 \mathrm{~L} /$ day * 30 days $=90,050.4 \mathrm{~L} / \mathrm{month}=23,788.798984 \mathrm{gal} / \mathrm{month}$, rounded to $23,789 \mathrm{gal} / \mathrm{month}$

5. Seasonal maximum fog water quantity harvested (assume 7-month fog season): 90,050.4 L/month * 7 months $=630,352.8 \mathrm{~L} /$ year

6. Amount of water stored at beginning of non-foggy season: $35,000 \mathrm{~L}$

7. Amount of water available for 5-month non-foggy season spread over period: $35,000 \mathrm{~L}$ total storage capacity, assuming at capacity thru end of foggy season / 5 months $=7,000$ L/month available during dry season

8. Proportion of water need being met during dry season: $7,000 \mathrm{~L} / \mathrm{month}$ available during dry season / 6,000 L/month needed for all planted areas $=116.67 \%$ of water need being met during dry season

\begin{tabular}{|l|c|c|c|c|c|c|c|c|c|c|c|c|}
\hline & \multicolumn{3}{|c|}{ SUMMER / NON-FOGGY SEASON } & \multicolumn{7}{c|}{ WINTER / FOGGY SEASON } \\
\hline & $\mathrm{D}$ & $\mathrm{J}$ & $\mathrm{F}$ & $\mathrm{M}$ & $\mathrm{A}$ & $\mathrm{M}$ & $\mathrm{J}$ & $\mathrm{J}$ & $\mathrm{A}$ & $\mathrm{S}$ & $\mathrm{O}$ & $\mathrm{N}$ \\
\hline & & & & & & & & & & & & \\
$\begin{array}{l}\text { Demand } \\
\text { throughout } \\
\text { month (L) }\end{array}$ & 6,000 & 6,000 & 6,000 & 6,000 & 6,000 & 6,000 & 6,000 & 6,000 & 6,000 & 6,000 & 6,000 & 6,000 \\
\hline $\begin{array}{l}\text { Amount stored at } \\
\text { beginning of } \\
\text { month (L) }\end{array}$ & 35,000 & 29,000 & 23,000 & 17,000 & 11,000 & 5,000 & 35,000 & 35,000 & 35,000 & 35,000 & 35,000 & 35,000 \\
\hline $\begin{array}{l}\text { Amount of } \\
\text { overflow during } \\
\text { that month (L) }\end{array}$ & & & & & & & & & & & & \\
\hline
\end{tabular}

Figure 2: Estimated water distribution throughout the year to guide design, Traction

\section{PIA calculations}

Post-project PIA Q3: "The fog collection and park made access to water..." $(n=23)$

6 people responded " 5 " (much better); $(6 / 23) * 100=26 \%$

11 people responded " 4 " (somewhat better); $(11 / 23)^{*} 100=48 \%$

6 people responded " 3 " (no change); $(6 / 23) * 100=26 \%$

0 people responded " 2 " (somewhat worse) or " 1 " (much worse)

Total positive responses for improved access ( 5 s and $4 \mathrm{~s}$ ): $6+11=17 ; 26 \%+48 \%=74 \%$

Cost savings calculations

Total minimum monthly water needs:

Monthly minimum household water needs: 
Given: According to community presidents, families made do with one 200-L or one 500$L$ container for one week of household water needs*; approximately half of families used 200-L containers and half used $500-\mathrm{L}$ containers.

Average water consumption per household $=(200+500) / 2=350 \mathrm{~L}$ per week $350 \mathrm{~L} * 90$ households $=31,500 \mathrm{~L}$ weekly water needs

$31,500 \mathrm{~L} * 4=126,000 \mathrm{~L}$ monthly household water needs for entire community

*This is an extremely low estimate for household water needs, as households practiced considerable water rationing before the project.

Monthly minimum greenspace water needs:

Given (see above): $200 \mathrm{~m}^{2}$ of green space has an average density of 4 plants $/ \mathrm{m}^{2}$. The water needs of each plant are approximately $7.5 \mathrm{~L}$ of water per month per plant. $200 \mathrm{~m}^{2} * 4$ plants $/ \mathrm{m}^{2}=800$ plants

Amount of water needed for planted areas monthly: 800 plants * $7.5 \mathrm{~L} /$ plant $/$ month $=$ $6,000 \mathrm{~L} / \mathrm{month}$

Total minimum monthly water needs: $126,000 \mathrm{~L}$ (households) $+6,000 \mathrm{~L}$ (green spaces) $=132,000 \mathrm{~L} / \mathrm{month}(34,870.71 \mathrm{gal} / \mathrm{week})$

Cost of public piped water:

Given: According to community presidents, before the project, the 70 families in the community paid 450 soles per month for public piped water, which filled each family's storage container about once per week. About half of families had 200-L containers and about half had $500-\mathrm{L}$ containers.

35 households * $200 \mathrm{~L}=7,000 \mathrm{~L}$

35 households * $500 \mathrm{~L}=17,500 \mathrm{~L}$

$7,000 \mathrm{~L}+17,500 \mathrm{~L}=24,500 \mathrm{~L}$

450 soles $/ 24,000 \mathrm{~L}=0.018367$ sol per $\mathrm{L}$ cost of public water

Cost of private trucked water:

Given: According to community presidents, it costs 20 soles to fill a $200 \mathrm{~L}$ water container with private trucked water.

20 soles $/ 200 \mathrm{~L}=.1$ sol per $\mathrm{L}$ cost of private water

Difference between public piped water and fog water (where fog water $=\$ 0.00$ per $\mathrm{L}$ )

- For minimum household needs: $126,000 \mathrm{~L} * 0.018367 \mathrm{sol}=\$ 2,314 \mathrm{soles} / \mathrm{mo}$ (approximately \$640 USD)

- For minimum household and greenspace needs: $132,000 \mathrm{~L}$ * $0.018367 \mathrm{sol}=\mathbf{2 , 4 2 4}$ soles/mo (approximately \$680 USD)

Difference between private trucked water and fog water (where fog water $=\$ 0.00$ per $\mathrm{L}$ ):

- For minimum household needs: $126,000 \mathrm{~L} * 0.10 \mathrm{sol}=\$ 12,600.00 \mathrm{soles} / \mathrm{mo}$ (approximately $\$ 3,535$ USD)

- For minimum household and greenspace needs: $132,000 \mathrm{~L}$ * $0.10 \mathrm{sol}=$ 


\section{3,200 soles/mo (approximately $\$ 3,700$ USD)}

Because source and usage varies monthly, this benefit is presented as a range.

\section{Sources:}

Environmental field measurements by research team (Feld et al, 2016)

Design calculations (unpublished, provided by Traction)

Average amount of water needed for plants provided by nursery that provided the plants

Surveyed household representatives' responses to PIA Q3

Household representatives' responses to Garden Diaries question

Heileman, S., Guevara, R., Chavez, F., Bertrand, A., and Soldi, H. (2009). "XVII-56 Humboldt

Current: LME \#13." NOAA, Silver Spring, MD.

Feld, S. I., Spencer, B. R., \& Bolton, S. M. (2016). Improved Fog Collection Using Turf

Reinforcement Mats. Journal of Sustainable Water in the Built Environment, 2(3).

doi:10.1061/JSWBAY.0000811

Limitations: Calculations are based on results from a relatively short field study (7 weeks) in the middle of the foggy season, and fog season length changes from an EI Niño year to a La Niña year, thus real rates of fog collection may differ from those projected in calculations. Climate change also poses limitations to the system, as the fog water collection period is projected to become less predictable, shorter, and dryer over time.

The fog water storage system lacks a comprehensive system for tracking water rationing, so it is unlikely that water is used at a consistent rate from month-to-month through the dry (non-foggy) season. Two taps provide access to stored water and may be used by community members for household needs; according to calculations, more than enough excess water exists during the foggy season, but this alternate usage may drain stores in the dry season as residents begin to reduce the reported rationing of their domestic water use-a risk mitigated by the seventh cistern's provision of $5,000 \mathrm{~L}$ more than the minimum required by planted areas.

Minimum monthly water needs are likely much higher than these data show, as community members were seen to be rationing water drastically before the project was implemented. Further, households likely filled their $200 \mathrm{~L}$ or $500 \mathrm{~L}$ containers and then had the water truck supplement when that amount ran out in a week's span. No data existed to draw these calculations, so values are likely much lower than reality, highlighting the need for water security that the project addressed.

Not all plants have the same water requirements, so the $7.5 \mathrm{~L} /$ month requirement assumed in calculations may not reflect real water needs of green spaces in Eliseo Collazos, though 7.5 $\mathrm{L} /$ month is a conservative estimate of water needs based upon asking residents how much they water their plants in the Garden Diaries pilot and referencing that information with the professional opinion of average water needs for fully grown plants by the owner of the nursery 
from whom the plants were purchased. Gardens have been expanded by residents beyond the project, increasing water requirements.

- Contributes to species diversity in an ecologically degraded region. Simpson diversity index values increased over the life of the project from a value of .86 at the first planting to .95 at 3.5 years after planting, even with the occurrence of a water crisis and significant dieback. The pre-project value is estimated to be near 0 .

Background: Informal urban communities often inhabit landscapes that are undesirable to more affluent urban dwellers who have access to conditions that are more conducive to human health including through access to resources, limited risk of disaster, public investment in infrastructure, and access to green space. Plant coverage is of particular importance in the hills surrounding Lima, as it offers critical solutions to erosion, landslides, and soil degradation in the ecologically degraded Lomas ecosystem. Increased air particulates from the exposed sandy and windy conditions exacerbate respiratory diseases such as tuberculosis, which is found in Lima's informal communities.

The lomas ecosystem is incredibly delicate with a thin layer of soil and seeds fed by fog water. With urbanization, mining, and deforestation disturbance in this area, the community started out with almost no plants or plant biodiversity. The team noted there weren't even weeds growing in 2011 during the first visit to the community. This lack of habitat also contributed to a significant lack of non-plant diversity, with little presence of avian, insect, and other species. In addition, Eliseo Collazos had no public green space, which is why the residents identified access to greenspace as a top priority in the participatory workshops.

Method: Methods include 1) plant counts by project team (method 4 in Methods Overview) and 2) and 3) analysis of plant counts using the Simpson and Shannon-Wiener diversity indices:

1) The project team recorded the number of plants in the community farm-park and both rounds of household gardens using field measures, providing general information on home garden plant communities over time as well as foundational data for diversity indices.

2) and 3) Diversity indices used data from field measures to identify plants that existed in the 29 gardens constructed in the first round of home gardens at three different points in time. Plants include those provided to community members as part of the project as well as plants procured and planted by community members outside of the project. Each index examines the diversity of pre-existing plants in Eliseo Collazos (baseline), as well as plant diversity at 6 months and 3.5 years after the gardens were installed. The 29 gardens analyzed represent $48 \%$ of the total home gardens installed over the course of the project and $30 \%$ of households in Eliseo Collazos when the project started.

The Simpson diversity index measures species diversity on a scale of 0 to 1 where $0=$ zero 
diversity and 1 = infinite diversity. The Shannon-Weiner diversity index measures species diversity using scores that indicate levels of diversity as follows: a score of less than $1.5=$ low diversity; a score between 1.5 and 2.5 = medium diversity; a score higher than $2.5=$ high diversity.

\section{Calculations:}

1) Lists of the number of plants purchased and planted as part of the project:

Plants planted in community farm-park: 1,384

Plants planted in first round of home gardens: 388

Plants planted in second round of home gardens: approximately 372

Plants added to first round of home gardens in July 2015: 125

Total plants planted in home gardens: $388+372+125=885$

Total plants provided as part of project: $1,384+885=2,269$

2) and 3) Baseline had 95 total specimens and 19 different species

6 months had 495 total specimens and 78 different species

3.5 years had 377 total specimens and 48 different species

Simpson diversity index:

Diversity went up from .86 at baseline to .97 at 6 months.

Even at 3.5 years during the water crisis and significant dieback, diversity remained at .95

Shannon-Wiener diversity index:

Diversity went up from 2.345 (medium diversity) at baseline to 3.897 (extremely high diversity) at 6 months.

At 3.5 years, during the water crisis and significant die back, diversity remained extremely high at 3.368 .

Sources: Plant lists at time of installation and subsequent plant counts by project team

Limitations: Species diversity indices are more commonly used in ecology, not for home gardens. However, in an area that previously had no vegetation, indices are a useful way to convey species diversity.

The field team was only able to track the plants in the gardens over a span of 3.5 years, and so these amounts do not accurately reflect the current situation. In addition, when the team first connected with the community in 2011 there were almost no plants in the entire community, however the team did not anticipate the importance of this observation and did not do a baseline plant count at that time. The baseline was conducted 2 years later when residents had started to express their desire for greenspace by planting trees and succulents at their houses. The design team also did not anticipate such an immediate impact the greenspace would have on animal/insect species counts for various pollinators, avian species, insects, arachnids, reptiles and others, and did not measure these factors. An analysis of animal/insect diversity and habitat change would have been beneficial in understanding habitat for this project. 
The field team only conducted plant counts at those houses who participated in the household gardens projects, however the team noted that households in the community who did not participate in the project also began growing their own gardens upon seeing their neighbor's gardens.

The plant counts conducted 3.5 years after the first round of gardens were installed happened to occur at a very hot period in the non-foggy season during a Lima-wide water crisis that cut the water supply throughout the city for two weeks. During this time, Eliseo Collazos had an emergency water supply in harvested fog water, upon which they relied for non-consumptive household needs. The green spaces that the fog water system was designed to sustain likely suffered some neglect while the water was diverted to other needs and so the plant counts at 3.5 years likely were lower than right before the water crisis began.

\section{Social Benefits}

- Increases time spent outdoors for $81 \%$ of 21 surveyed household representatives. $79 \%$ of 19 surveyed household representatives reported that their children spend more time outdoors because of the project.

Background: Spending time outdoors and especially in green spaces is linked to myriad health benefits, including physical activity, mental health and well-being, and access to ventilated air. This is of particular interest for people living in Lima's crowded informal housing, which sees high rates of tuberculosis and other respiratory diseases. Community members identified having places to recreate outdoors as a top priority in needs and priorities workshops.

Method: Methods include 1) and 2) two questions included in the PIA surveys (method 1 in Methods Overview):

1) "The projects have influenced the time YOU spend outside..." and 2) "The projects have influenced the time YOUR CHILDREN spend outside..." Responses were on a scale of 1 to 5 , where $1=$ much less time outside and $5=$ much more time outside. Responses were counted and total positive responses ( $5 \mathrm{~s}$ and $4 \mathrm{~s}$ ) were added to find total participants reporting improvement. 21 out of $23(91.3 \%)$ and 19 out of 23 (82.6) surveyed household representatives answered the questions, respectively. Percentages were calculated based on $n$ values of 21 and 19 , representing $26 \%$ and $23 \%$ of the households in Eliseo Collazos when the project started, respectively. (The n-value for children is likely lower because not all households have children.)

\section{Calculations:}

1) Post-project PIA Q5: "The projects have influenced the time you spend outside..." ( $n=21)$ 
4 people responded " 5 " (much more) ; $(4 / 21) * 100=19 \%$

13 people responded " 4 " (somewhat more) ; $(13 / 21) * 100=62 \%$

1 person responded " 3 " (no change) ; $(1 / 21)^{*} 100=5 \%$

2 people responded "2" (somewhat less) ; $(2 / 21)^{*} 100=10 \%$

1 person responded " 1 " (much less) ; $(1 / 21) * 100=5 \%$

Total positive responses ( $5 \mathrm{~s}$ and $4 \mathrm{~s}$ ): $4+13=17 ; 19 \%+62 \%=81 \%$

2) Post-project PIA PIA Q5: "The projects have influenced the time your children spend outside..." (n=19)

6 people responded " 5 " (much more) ; $(6 / 19) * 100=32 \%$

9 people responded " 4 " (somewhat more) ; $(9 / 19) * 100=47 \%$

3 person responded " 3 " (no change) ; $(3 / 19) * 100=16 \%$

0 people responded " 2 " (somewhat less) ; $(0 / 19) * 100=0 \%$

1 person responded " 1 " (much less) ; $(1 / 19) * 100=5 \%$

Total positive responses (5s and $4 \mathrm{~s}$ ): $6+9=15 ; 32 \%+47 \%=79 \%$

Sources: Surveyed household representatives' responses to PIA Q5

Limitations: Because the questions were answered only by one representative per household, data captures the behavior of a small portion of the overall community; the household head may spend much more or much less time outdoors than other members of their household.

- Fosters personal agency and stewardship, with 28 of the 29 households that participated in the first phase of household gardens adding new plants to their gardens of their own volition. These plants added by residents made up $45 \%$ of the 495 plants in the household gardens six months after construction.

Background: Due to public disinvestment and low income of community members, the community of Eliseo Collazos was devoid of shared or private green spaces before the project. Adding green spaces to the community was among community members' top priorities for change. The initial plants in the Phase 1 community gardens were purchased for community members. In the immediate wake of construction of different green spaces, community members began to invest time, energy, and personal resources in the gardens' maintenance and growth, demonstrating personal agency and stewardship of the project that is elemental in sustaining community-based landscape interventions. Indicators such as personally installed plants, sculpture, art, and garden expansion show an emotional investment in the project and increase the likelihood that the project will continue to provide benefits long after the project team has left.

Methods: Methods include 1) plant counts by the project team (see method 4 in Methods Overview) and 2) Garden Diaries (method 3 in Methods Overview):

1) The project team recorded quantities and what types of plants were planted in each of the 29 
gardens planted in the first round of home gardens. Plant species were counted at the time of installation with follow up at 6 months and 3.5 years to monitor plant changes over time. At the 6-month follow-up, the project team distinguished in their counts which plants that were provided to community members as part of the home gardens project as well as additional plants that participating households had personally added to their gardens.

\begin{tabular}{|c|l|c|}
\hline \multicolumn{3}{|l|}{ home gardens self-investment $(\mathrm{n}=29)$} \\
\hline \multirow{4}{*}{ baseline } & existing plants pre-project & 95 \\
\cline { 2 - 3 } & plants provided at installation & 388 \\
\cline { 2 - 3 } & $\begin{array}{l}\text { total plants immediately post- } \\
\text { installation (95+388) }\end{array}$ & 483 \\
\hline \multirow{5}{*}{6 months } & $\begin{array}{l}\text { Project provided plants } \\
\text { counted at 6 months }\end{array}$ & 274 \\
\cline { 2 - 3 } & $\begin{array}{l}\text { plants provided by community } \\
\text { (self-investment) at 6 months }\end{array}$ & 221 \\
\cline { 2 - 3 } & $\begin{array}{l}\text { total plants at 6 months } \\
(274+221)\end{array}$ & 495 \\
\cline { 2 - 3 } & $\begin{array}{l}\text { percent self-investment } \\
(221 / 495)\end{array}$ & $44.65 \%$ \\
\hline
\end{tabular}

Figure 4: Self investment of plants in Phase I household gardens

Of the 495 total plants counted in the 29 gardens constructed in Phase I of the household gardens six months after implementation, 221 were provided by the community, representing $44.65 \%$ of plants. Households personally added a maximum of 21 and an average of 7.6 plants to their gardens. This personal investment demonstrates satisfaction with the project and an eagerness among community members to invest in their home gardens despite living in severe poverty, and suggests sustainability and stewardship within the community of Eliseo Collazos for years to come. The latter point is further reinforced by plant counts conducted 3.5 years after installation of the Phase I household gardens, with 377 plants still remaining despite a regional water crisis during the peak of the dry season. In addition, 57 of the 60 (95\% of) total household gardens were still present 3.5 years after Phase I and 1.5 years after Phase II.

2) Of the 29 households who participated in Phase I of the household gardens, 26 households kept Garden Diaries, capturing garden activity in $89.7 \%$ of gardens from this first phase. Two findings presented in this benefit come from one prompt: participating households were prompted to record how many plants they planted each week. Findings include 1) The number of households that recorded one or more planting over the 14-week period were counted to find the number of households that reported adding to their gardens; and 2) All numbers recorded were added to find the total number of plants planted in the households that added to their gardens. In the 14-week span after home gardens were installed, 22 out of 26 participating 
households reported planting more than 50 species in 102 instances of adding new plants to their gardens.

\section{Sources:}

Plant counts by project team

Garden Diaries responses by residents

Limitations: The plant counts describe activities in the 29 gardens built during Phase I of the household gardens, thus conclusions reflect slightly less than half of the total 60 home gardens constructed in both phases combined. Subsequent plant counts for Phase II household gardens did not distinguish between plants provided by the project versus self-invested.

- Improves interpersonal relationships, with $86 \%$ of 21 surveyed community members reporting that relationships and collaboration with their neighbors were improved by the project, while $65 \%$ of 23 reported that they spent more time with neighbors than before the project. This is supported by statistically significant positive change in social capital measured in a health assessment of participants.

Background: Low-resource communities like Eliseo Collazos, which receive extremely little public support and whose residents live in poverty, rely on social resources within the community. When access to the services and support that monetary wealth can provide are limited, these social resources are critical for individual and community resilience. Gardens have been shown to facilitate and strengthen inter-community social cohesion. A 2015 study found that people living in communities that foster green spaces feel safe, accepted, valued, and a sense of belonging and contributing to a greater purpose; these gardens promote social learning while facilitating social connection and participation through the creation of flexible environments that support diverse individuals (Goldstein et al.).

The Fog Water Farm-Park and Gardens research team suspected that the projects, and specifically the processes of designing and implementing household gardens, would impact community cohesion and social health. Community relationships are an indicator of social cohesion and resilience potential in low-income communities. For these reasons, the research team felt that it was important to include questions about interpersonal relationships within the community in post-project PIAs and to triangulate these measures with a validated survey with social health measures.

Community bonding was a common theme discussed in open-ended questions in the postproject PIA. One person said that what they liked about the fog collection system and park was the opportunity for community members to help one another throughout the process. Another participant said that they liked sharing time with family and friends, while yet another cited welcome distraction for themselves and entertainment for their children.

Method: Methods include 1) and 2) two questions included in PIA surveys (method 1 in Methods 
Overview) and 3) health assessment by nurses (method 2 in Methods Overview):

1) "The projects have influenced your relationships with your neighbors in Eliseo Collazos...?" and 2) "The projects have influenced time spent with your neighbors...?" Responses were on a scale of 1 to 5 , where 1 is much worse/less and 5 is much improved/more. Responses were counted and total positive responses ( $4 \mathrm{~s}$ and $5 \mathrm{~s}$ ) were added to find total participants reporting improvement or more time spent with neighbors. 21 and $23(91 \%)$ and 23 out of $23(100 \%)$ surveyed household representatives answered the questions. Percentages were determined using $n$ values of 21 and 23 , representing $26 \%$ and $28 \%$ of households in Eliseo Collazos when the project started, respectively.

3) The health assessment by nurses included the Social Capital Scale, a World Health Organization (WHO) validated instrument to understand the social effects of environmental change at the community scale. A paired t-test was utilized to show changes in mean scores in the 7 subcategories of the SCS (Trust/Safety, Participation, Diversity, Neighborhood, Value of Life, Family/Friends, and Social Agency) from the baseline to 12 months after garden construction. The analysis showed statistically significant improvement $(p<0.01)$ in social capital from the baseline to 12 months after garden construction.

\section{Calculations:}

1) Post-project PIA Q5: "The projects have influenced your relationships with your neighbors in Eliseo Collazos...?" $(n=21)$

7 people responded " 5 " (have much improved) ; $(4 / 21)^{*} 100=33 \%$

11 people responded " 4 " (have improved); $(7 / 21) * 100=52 \%$

3 people responded " 3 " (are the same); $(11 / 21) * 100=14 \%$

0 people responded " 2 " (have worsened) or " 3 " (have much worsened)

Total positive responses (4s and $5 s): 7+11=18 ;(18 / 21)^{\star} 100=86 \%$

2) Post-project PIA Q5: "The projects have influenced the time spent with your neighbors...?" $(n=23)$

2 people responded " 5 " (much more time than before) ; $(2 / 23)^{*} 100=9 \%$

13 people responded " 4 " (more time than before) : $(13 / 23)^{\star} 100=57 \%$

5 people responded " 3 " (same as before); $(5 / 23) * 100=22 \%$

2 people responded " 2 " (less time than before) ; $(2 / 23) * 100=9 \%$

1 person responded " 3 " (much less time than before) ; $(1 / 23)^{*} 100=4 \%$

Total positive responses (4s and $5 s$ ): $2+13=15 ;(15 / 23)^{*} 100=65 \%$

3) Full methods and calculations published in Korn et al. 2018. Summarized Social Capital Scale (SCS) Score:

Baseline ( $\mathrm{n}=29)$ : mean score 72.5 (SD 10.0)

12 Months $(\mathrm{n}=26)$ : mean score 83.6 (SD 10.1)

Increase in mean $=83.6-72.5=11.1(13.28 \%$ increase in social capital $)$

Paired t-test $(n=26): p<0.01$ 


\section{Sources:}

Surveyed household representatives' responses to PIA Q5

Health assessment by nurses (Korn et al. 2018)

Goldstein, J., Jacoby, E., del Aguila, R., \& Lopez, A. (2005). Poverty is a predictor of noncommunicable disease among adults in Peruvian cities. Prev Med, 41(3-4), 800-806. doi:10.1016/j.ypmed.2005.06.001

Limitations: Capture for the PIA is low compared to the population of the community. While about a fourth of households were represented in the PIA, only one adult from each household completed the PIA, and at an estimated population in the community of about 350 , responses only represent $8 \%$ of the residents, leaving out children and adults who are not the heads of households in the social capital measures. Similarly, while all 29 households who participated in Phase I of the household gardens were represented in the health assessment, these data only represents one adult per household.

\section{- Promotes physical activity, with $67 \%$ of 21 surveyed household representatives reporting spending more time exercising or playing sports than before the project.}

Background: The community previously lacked shared space for playing sports or playing games, and identified space for recreation as a top priority in community workshops. The Fog Water Farm-Park includes a recreational court most often used for culturally beloved soccer and volleyball games. Evidence has shown strong associations between low socioeconomic status and higher burdens of non-communicable diseases like cardiovascular disease and type 2 diabetes in Peru (Goldstein et al.). Increased consumption of fruits and vegetables and reduced $\mathrm{BMI}$ are effective methods of reducing the disproportionate prevalence of these chronic conditions in Lima's informal communities (Korn et al.).

Method: Methods include 1) a question included in a post-project PIA survey (method 1 in Methods Overview) and 2) the health assessment by nurses (method 2 in Methods Overview):

1) "The projects have influenced the time you spend exercising or playing sports..." Responses were on a scale of 1 to 5 , where $1=$ much less and $5=$ much more. Responses were counted and total positive responses ( $4 \mathrm{~s}$ and $5 \mathrm{~s}$ ) were added to find total participants reporting improvement. 21 out of 23 (91.3\% of) surveyed household representatives answered the question. Percentages were calculated based on an $n$ value of 21 , representing $26 \%$ of households in Eliseo Collazos when the project started. Anecdotal observation indicates that the playfield is used daily, helping parents to keep their children busy and healthy.

2) The health assessment by nurses included an analysis of anthropometric (physical) health metrics including body mass index (BMI), waist circumference (WC), and fasting blood glucose (FBC). A paired t-test was utilized to show changes in mean scores from the baseline to 6 months and the baseline to 12 months post-garden construction. 
There were no statistically significant changes over the course of the one year study. However, a comparison of the physical metrics of Eliseo Collazos community members to those measured in a previous study of physical health in the larger Alto Zapallal area suggested lower rates of type 2 diabetes, lower rates of high blood pressure, and a lower proportion of the population that is overweight or obese. The research team speculated that these differences may be attributable to the fact the Eliseo Collazos had been settled relatively recently and to the exercise that community members reported getting from regularly climbing the sandy hills in the neighborhood that buses and cars could not navigate. For further discussion, see Korn et al., 2018.

\section{Calculations:}

1) Post-project PIA Q5: "The projects have influenced the time spent exercising and playing sports..." (n=21)

2 people responded " 5 " (much more) ; $(2 / 21) * 100=10 \%$

12 people responded " 4 " (somewhat more) ; $(12 / 21) * 100=57 \%$

6 people responded " 3 " (no change) ; $(6 / 21) * 100=29 \%$

0 people responded " 2 " (somewhat less) ; $(0 / 21) * 100=0 \%$

1 person responded " 1 " (much less) ; $(1 / 21) * 100=5 \%$

Total positive responses ( $5 \mathrm{~s}$ and $4 \mathrm{~s}$ ): $2+12=15 ; 10 \%+57 \%=67 \%$

2) Results of the health assessment's physical measures are shown in the table.

Table 2. The physical health metrics at enrollment and at six and twelve months.

\begin{tabular}{|c|c|c|c|c|c|c|c|c|}
\hline \multirow[t]{2}{*}{ Variable } & \multicolumn{2}{|c|}{$\begin{array}{c}\text { Baseline } \\
N=29 \\
\end{array}$} & \multicolumn{3}{|c|}{$\begin{array}{c}\text { 6-Months } \\
N=28\end{array}$} & \multicolumn{3}{|c|}{$\begin{array}{c}\text { 12-Months } \\
N=26\end{array}$} \\
\hline & Mean & $\mathrm{SD}$ & Mean & $\mathrm{SD}$ & $p$ & Mean & SD & $p$ \\
\hline BMI & 24.3 & 5.1 & 24.1 & 5.2 & 0.12 & 24.5 & 5.5 & 0.95 \\
\hline $\mathrm{WC}^{*}(\mathrm{~cm})$ & 89.4 & 13.4 & 87.2 & 8.5 & 0.40 & 92.8 & 13.2 & 0.18 \\
\hline $\mathrm{FBG}^{+}(\mathrm{mg} / \mathrm{dL})$ & 89.9 & 8.9 & 94.0 & 7.2 & $0.04 * *$ & 91.1 & 8.5 & 0.59 \\
\hline Systolic & 115.2 & 11.4 & 115.5 & 9.0 & 0.75 & 114.6 & 15.9 & 0.66 \\
\hline Diastolic & 72.3 & 10.1 & 73.0 & 10.0 & 0.77 & 73.8 & 9.4 & 0.69 \\
\hline
\end{tabular}

Legend: * Waist Circumference; $†$ Fasting blood glucose; ${ }^{* *} p<0.05$; bold means significant differences at 6 but not 12 months.

[Table: Physical health metrics at enrollment and at six and 12 months, from Korn et al, 2018]

Sources: Surveyed household representatives' responses to PIA Q5

Goldstein, J., Jacoby, E., del Aguila, R., \& Lopez, A. (2005). Poverty is a predictor of noncommunicable disease among adults in Peruvian cities. Prev Med, 41(3-4), 800-806.

doi:10.1016/j.ypmed.2005.06.001

Korn, A., Bolton, S. M., Spencer, B., Alarcon, J. A., Andrews, L., \& Voss, J. G. (2018). Physical and Mental Health Impacts of Household Gardens in an Urban Slum in Lima, Peru. International Journal of Environmental Research and Public Health, 15(8), 1751. doi:10.3390/ijerph15081751 
Limitation: The PIA question was directed at household representatives and thus does not capture changes in time spent exercising or playing sports for each individual in the community.

Limitations of the study of physical measures by nurses include a short study period, as anthropometric changes often take longer than one year to change. Furthermore, the research team suggested that in order to assess the effects of home gardens on community members a future study might collect data on nutrition.

- Contributes to improved mental health and well-being for community members, with a statistically significant increase in psychological health based on a health assessment of 29 community members. Additionally, 95\% of 20 surveyed household representatives reported that their home gardens improved their mental health, well-being, and happiness.

Background: Low income informal communities like Eliseo Collazos face disproportionate risk of sub-optimal mental health and well-being stemming from the stresses of socioeconomic inequality, lack of formalized public health infrastructure, and prevalence of urban stressors like noise and air pollution, urban heat island effect, and fear of crime. The restorative functions of green space in relieving stress are likely to play a role in urban dwellers' affinity for green space (Korn et al.). Community members in Eliseo Collazos suggested this affinity in community meetings and workshops where green space was made a principal priority.

Furthermore, research has demonstrated associations between individual mental health outcomes and perceived quality and quantity of green space (1), suggesting that the community participatory processes behind built environment interventions are as important as physical outcomes themselves in building momentum toward optimal mental health and well-being. For these reasons, the project team found it important to include instruments in PIAs (which reflect community priorities as well as definitions of success) and the health assessment by nurses to measure community-scale effects of the built environment interventions on mental health and well-being.

Among common themes mentioned in an open-ended questions in the post-project PIA that asked what changes in the community influenced mental health, happiness, and well-being were: looking at gardens and green spaces, harvesting medicinal and edible plants, the health benefits of gardens, working on gardens, shade, and healthier air.

Method: Methods include 1) an instrument in the health assessment by nurses (method 2 in Methods Overview) and 2) and 3) two questions included in PIA surveys (method 1 in Methods Overview):

1) The health assessment by nurses included the Psychological domain, a subscale from the World Health Organization Quality of Life Brief Version (WHOQOL-BREF) scale, which measures the psychological health effects of environmental change at the community scale. A 
paired t-test was utilized to show changes in mean scores in the Psychological domain from the baseline to 12 months post-garden construction. The analysis showed statistically significant improvement $(p=0.02)$ in psychological health from the baseline to 12 months after garden construction. (See the next benefit for discussion of the WHOQOL-BREF.)

2) "How do you feel about your mental health, happiness, and well-being?" was asked in PIA surveys both pre- and post-project implementation. Responses were on a scale of 1 to 6 , where $1=$ very happy and $6=$ very unhappy. Responses were averaged both pre-project and postproject. The post-project average was subtracted from the pre-project average to find change. A difference ranging from 0 to .9 was considered minor improvement; a change of 1 or higher was considered a significant improvement. 18 and 16 household representatives participated in the pre- and post-project PIAs, respectively, representing $22 \%$ and $20 \%$ of households in Eliseo Collazos when the project started. These questions showed only a minor improvement and are therefore not reported in the main benefit.

3) "The project of home gardens made your mental health, well-being, and happiness..." Responses were on a scale of 1 to 5 , where $1=$ much worse and $5=$ much better. Responses were counted and total participants reporting positive responses ( $4 \mathrm{~s}$ and $5 \mathrm{~s}$ ) were added to find total participants reporting improvement. 20 out of $21(95.2 \%)$ surveyed household representatives answered the question. Percentages were calculated based on an $n$ value of 20 , representing $33 \%$ of the 60 total households that built home gardens.

\section{Calculations:}

Full methods and calculations for 1) can be found in Korn et al. 2018.

1) Summarized Psychological domain score:

Baseline ( $\mathrm{n}=29)$ : mean score 14.3 (SD 2.3)

12 Months ( $n=26)$ : mean score 15.5 (SD 2.4)

Increase in mean $=15.5-14.3=1.2(7.7 \%$ increase in psychological well-being $)$

Paired t-test $(n=26): p<0.05$

2) Pre- and post-project PIA Q2: "How do you feel about your mental health, happiness, and well-being?"

Pre-project PIA ( $n=18)$

10 people responded "1" (very happy)

4 people responded " 2 "

4 people responded " 3 "

0 people responded " 4 "

0 people responded " 5 "

0 people responded "6" (very unhappy)

$\left(\left[10^{*} 1\right]+\left[4^{*} 2\right]+\left[4^{*} 3\right]\right) / 18=30 / 18=1.67$ average

Post-project PIA ( $n=16)$ 
11 people responded " 1 " (very happy)

3 people responded " 2 "

0 people responded " 3 "

2 people responded " 4 "

0 people responded " 5 "

0 people responded " 6 " (very unhappy)

$\left(\left[11^{*} 1\right]+\left[3^{*} 2\right]+\left[2^{*} 4\right]\right) / 16=25 / 16=1.56$ average

$1.67-1.56=0.11 ;$ minor improvement

3) Post-project PIA Q4: "The project of home gardens made your mental health, well-being, and happiness..." $(\mathrm{n}=20)$

8 people responded " 5 " (much improved) ; $(8 / 20)^{\star} 100=40 \%$

11 people responded " 4 " (somewhat improved) ; $(11 / 20)^{*} 100=55 \%$

1 person responded " 3 " (no change) ; $(1 / 20)^{*} 100=5 \%$

0 people responded " 2 " or " 1 "

Total positive responses (5s and 4s): $8+11=19 ;(19 / 20)^{*} 100=95 \%$

\section{Sources:}

Surveyed household representatives' responses to health assessment Surveyed household representatives' responses to PIA Q2 and Q4

Korn, A., Bolton, S. M., Spencer, B., Alarcon, J. A., Andrews, L., \& Voss, J. G. (2018). Physical and Mental Health Impacts of Household Gardens in an Urban Slum in Lima, Peru. International Journal of Environmental Research and Public Health, 15(8), 1751. doi:10.3390/ijerph15081751

Limitations: Capture for the PIA is low compared to the population of the whole community. While about a fourth of households were represented in the PIA, only one adult from each household completed the PIA, leaving out adults who are not the heads of households in the mental health and well-being measures (children are not applicable in this scale). Similarly, while all 29 households who participated in Phase I of the household gardens were represented in the health assessment, these data only represent one adult per household.

Findings of both the PIA and health assessment show variation in mental health and well-being outcomes, including improvements of mental well-being varying from slight increases to significant increases. This suggests that mental health and well-being factors for this severely disadvantaged community is impacted by a variety of life factors difficult to isolate from the gardens landscape intervention. For example mafia presence and nearby settlements had begun to increase over the course of the health assessment which may reflect an increase in perceived stress, yet these were newer developments so that violence was not yet experienced and the gardens may be keeping resident's preoccupied and more staying at home which could be why life threatening experiences were found to have decreased (Korn et al.). Similarly, in the PIA the residents' general state of mental well-being increased only slightly; however, residents overwhelmingly reported that the household gardens contributed to an increase in their mental 
well-being. Without a paired qualitative follow-up it is difficult to understand the nuances of the context and is therefore a limitation of the study.

- Improves quality of life according to $100 \%$ of 19 surveyed household representatives. A health assessment of 29 community members showed a statistically significant increase in all quality of life domains including physical health (14.2\% improvement), psychological health (7.7\%), social relationships (11.9\%), and environment (9.2\%) in the course of one year.

Background: In low-income and informal communities, the harsh environmental conditions and lack of services and wealth contributes to lower quality of life than wealthier urbanites. Based on existing literature, the research team suspected that the projects would impact quality of life among residents. For these reasons, the research team determined quality of life to be an important component of PIAs and the health assessment.

Method: Methods include 1) and 2) two questions included in PIA surveys (method 1 in Methods Overview) and 3) health assessment by nurses (method 2 in Methods Overview):

1) "How do you feel about quality of life in your community?" This general question was asked both pre- and post-project implementation. Responses were on a scale of 1 to 6 , where $1=$ very happy and 6 = very unhappy. Responses were averaged both pre-project and post-project. The post-project average was subtracted from the pre-project average to find change. A difference ranging from 0 to .9 was considered minor improvement; a change of 1 or higher was considered significant improvement. 18 and 16 household representatives participated in the pre- and post-project PIAs, respectively, representing $22 \%$ and $20 \%$ of households in Eliseo Collazos when the project started.

2) "The project of home gardens made your quality of life..." Responses were on a scale of 1 to 5 , where $1=$ much worse and $5=$ much better. Responses were counted, and total positive responses (4s and 5s) were added to find total participants reporting improvement. 19 out of 21 $(90.5 \%)$ surveyed household representatives answered the question. Percentages were calculated based on an $n$ value of 19 , representing $32 \%$ of the 60 total households that built home gardens.

3) The health assessment by nurses included several validated quality of life instruments including the World Health Organization Quality of Life Brief Version (WHOQOL-BREF), which measures broad domains of physical health, psychological health, social relationships, and environment. A paired t-test was utilized to show changes in mean scores in WHOQOL-BREF domains from the baseline to 6 months and the baseline to 12 months post-garden construction. The analysis showed statistically significant increases from the baseline to 12 months after garden construction in all domains of quality of life, including: Physical: $p<0.01$; Psychological: $p<0.05$; Social: $p=0.02$; and Environmental: $p=0.02$ 


\section{Calculations:}

1) Pre- and post-project PIA Q2: "How do you feel about quality of life in your community?"

Pre-project PIA $(\mathrm{n}=18)$

10 people responded " 1 " (very happy)

1 person responded " 2 "

4 people responded " 3 "

2 people responded " 4 "

0 people responded " 5 "

1 person responded " 6 " (very unhappy)

$\left(\left[10^{\star} 1\right]+\left[1^{*} 2\right]+\left[4^{\star} 3\right]+\left[2^{*} 4\right]+\left[1^{*} 6\right]\right) / 18=38 / 18=2.11$ average

Post-project PIA ( $\mathrm{n}=16)$

6 people responded "1" (very happy)

7 people responded " 2 "

1 person responded " 3 "

1 person responded " 4 "

1 person responded " 5 "

0 people responded " 6 " (very unhappy)

$\left(\left[6^{*} 1\right]+\left[7^{*} 2\right]+\left[1^{*} 3\right]+\left[1^{*} 4\right]+\left[1^{*} 5\right]\right) / 16=32 / 16=2$ average

$2.11-2=0.11$; minor improvement. This was therefore not reported in the primary benefit.

2) Post-project PIA Q4: "The project of home gardens made your quality of life..." ( $n=19)$

12 people responded " 5 " (much better than before) ; $(12 / 19)^{*} 100=63 \%$

7 people responded " 4 " (better than before ; $(7 / 19) * 100=37 \%$

0 people responded " 3 ," (the same) "2," (worse than before) or " 1 " (much worse than before)

Total positive responses (5s and $4 \mathrm{~s}): 12+7=19 ;(19 / 19)^{*} 100=100 \%$

3) Full methods and calculations published in Korn et al. 2018.

Summarized Quality of Life, Physical domain score:

Baseline $(n=29)$ : mean score 13.3 (SD 2.0)

12 Months $(n=26)$ : mean score 15.5 (SD 2.4$)$

Increase in mean $=15.5-13.3=2.2(14.2 \%$ increase in physical well-being $)$

Paired t-test $(n=26): p<0.01$

Summarized Quality of Life, Psychological domain score:

Baseline ( $\mathrm{n}=29)$ : mean score 14.3 (SD 2.3)

12 Months $(n=26)$ : mean score 15.5 (SD 2.4)

Increase in mean $=15.5-14.3=1.2(7.7 \%$ increase in psychological well-being $)$

Paired t-test $(n=26): p<0.05$

Summarized Quality of Life, Social domain score: 
Baseline ( $n=29)$ : mean score 13.3 (SD 3.0)

12 Months ( $\mathrm{n}=26)$ : mean score 15.1 (SD 3.0)

Increase in mean $=15.1-13.3=1.8(11.9 \%$ increase in social well-being)

Paired t-test $(n=26): p=0.02$

Summarized Quality of Life, Environmental domain score:

Baseline ( $n=29)$ : mean score 11.8 (SD 1.5)

12 Months $(n=26)$ : mean score 13.0 (SD 1.7)

Increase in mean $=13.0-11.8=1.2(9.2 \%$ increase in environmental well-being $)$

Paired t-test $(n=26): p=0.02$

\section{Sources:}

Surveyed household representatives' responses to PIA Q4 and Q2

Health assessment by nurses (see Korn et al, 2018)

Limitations: Capture for the PIA is low compared to the population of the whole community. While about a fourth of households were represented in the PIA, only one adult from each household completed the PIA, leaving out adults who are not the heads of households in the quality of life measures (children are not applicable for this scale). Similarly, while all 29 households who participated in Phase I of the household gardens were represented in the health assessment, these data only represent one adult per household.

- Improves community perceptions of the environment, with $6 \%$ of surveyed household representatives being happy with the environment in their community pre-project improving to $69 \%$ post-project. Additionally, $90 \%$ of 20 surveyed household representatives believed that their home gardens made the environment in their community better.

Background: The lomas ecosystem that is home to the community of Eliseo Collazos and surrounding urban communities is ecologically degraded. Where the delicate greenery characteristic of the unique fog-fed lomas ecosystem once served as habitat for diverse nonhuman species, a dearth of green space hosts informal urbanization that is largely devoid of public investment, including a complete lack of the kinds of environments that promote human and ecological health in formal urban spaces. Participants in a PIA pilot contributed to a community definition of "environment" (translated from the Spanish medio ambiente) as the presence of plants and animals. Informal observations as well as documentation of existing plants at houses by the research team suggest that very little to no plant and non-human animal life in Eliseo Collazos existed prior to the landscape intervention.

Method: Methods include 1) and 2) two questions included in PIA surveys (see method 1 in Methods Overview):

1) "How do you feel about the environment in your community?" This general question was 
asked both pre- and post-project implementation. Responses were on a scale of 1 to 6 , where 1 $=$ very happy and $6=$ very unhappy. Responses were averaged both pre-project and postproject. The post-project average was subtracted from the pre-project average to find change. A difference ranging from 0 to .9 was considered minor improvement; a change of 1 or higher was considered significant improvement. 18 and 16 household representatives participated in the pre- and post-project PIAs, respectively, representing $22 \%$ and $20 \%$ of households in Eliseo Collazos when the project started.

2) "The project of home gardens made the environment in your community..." Responses were on a scale of 1 to 5 , where $1=$ much worse and $5=$ much better. Responses were counted and total participants reporting positive responses ( $5 \mathrm{~s}$ and $4 \mathrm{~s}$ ) were added to find total participants reporting improvement. 20 out of 21 (95.2\% of) surveyed household representatives answered the question. Percentages were calculated based on an $n$ value of 20 , representing $33 \%$ of the 60 total households that built home gardens.

\section{Calculations:}

1) Pre- and post-project PIA Q2: "How do you feel about the environment in your community?"

Pre-project PIA ( $n=18)$

0 people responded " 1 " (very happy)

1 person responded " 2 "

3 people responded " 3 "

5 people responded " 4 "

8 people responded " 5 "

1 person responded " 6 " (very unhappy)

$\left(\left[1^{*} 2\right]+\left[3^{*} 3\right]+\left[5^{*} 4\right]+\left[8^{*} 5\right]+\left[1^{*} 6\right]\right) / 18=77 / 18=4.28$ average

Positive scores ( 1 s and $2 \mathrm{~s}$ ): $0+1=6 \%$ happy or very happy

Post-project PIA ( $n=16)$

7 people responded "1" (very happy)

4 people responded " 2 "

1 person responded " 3 "

3 people responded " 4 "

1 person responded " 5 "

0 people responded "6" (very unhappy)

$\left(\left[7^{*} 1\right]+\left[4^{*} 2\right]+\left[1^{*} 3\right]+\left[3^{*} 4\right]+\left[1^{*} 5\right]\right) / 16=35 / 16=2.19$ average

Positive scores ( 1 s and 2 s): $7+4=69 \%$ happy or very happy

\section{$4.28-2.19=2.09 ;$ significant improvement}

2) Post-project PIA Q4: "The project of home gardens made the environment in your community..." (n=20)

8 people responded " 5 " (much improved) ; $(8 / 20) * 100=40 \%$

10 people responded " 4 " (somewhat improved) ; $(10 / 20) \star 100=50 \%$ 
2 people responded "3" (no change) ; $(2 / 20)^{*} 100=10 \%$

Total positive responses ( 5 s and $4 \mathrm{~s}$ ): $8+10=18 ; 40 \%+50 \%=90 \%$

Sources: Surveyed household representatives' responses to PIA Q2 + Q4

Limitations: Though household representatives that participated in the questionnaire pilot contributed to the definition of "environment" as the presence of plants and animals, perceptions of environment--types and quantities of plant and animal species--may differ from person to person. This definition of environment does not explicitly include environmental function or ecosystem services which are concepts beyond what most community members can comprehend (average second grade education level).

- Helps to combat declining perceptions of security in the community, with $96 \%$ of 21 surveyed household representatives reporting that security in the community either did not change or improved, despite an overall increase in crime in the region. The project also catalyzed significant increases in feelings of trust and safety and decreases in life-threatening experiences associated with home garden construction as indicated in a health assessment.

Background: Based on informal conversations with community members, the research team learned that the area around Eliseo Collazos has seen an increase in gang activity and in parent concern for their teenagers' involvement. This is part of the motivation behind community members who identified space for active recreation in community workshops as a priority--the implementation of the sports field that hosts soccer and volleyball and a secure playground for young children are in part responses to this concern. A question about security was added to a PIA to gauge participants' perceptions of change in security after the project was completed.

Security was defined as a feeling of personal safety and a lack of perceived crime, and this definition was reiterated at the time of PIA administration. That 48 percent of surveyed household representatives reported that security did not significantly change in the community does not only reflect a lack of improvement but notably also reflects a lack of worsening. At the time of the PIA, the area surrounding Eliseo Collazos had seen increases in crime with the recent surge in mafia presence and gun activity; the fact that participating household representatives did not report worsening is a noteworthy improvement from their baseline concern.

Method: Methods include 1) a question included in a PIA survey (see method 1 in Methods Overview) and 2) and 3) two scales included in the health assessment by nurses (see method 2 in Methods Overview):

1) "The projects have influenced security in your community..." Responses were on a scale of 1 to 5 , where 1 is much worse and 5 is much better. Responses were counted and total participants reporting positive responses ( $4 \mathrm{~s}$ and $5 \mathrm{~s}$ ) were added to find total participants 
reporting improvement. 23 out of 23 (100\% of) surveyed household representatives answered the question. Percentages were determined using an $n$ value of 23 , representing $28 \%$ of households in Eliseo Collazos when the project started.

2) The health assessment by nurses included the Life-Threatening Experiences, 12-Item (LTE12) scale, a World Health Organization (WHO) validated instrument to understand the effects of environmental change on life threatening experiences at the community scale. A paired t-test was utilized to show changes in mean scores on the LTE-12 from the baseline to 12 months post-garden construction. The analysis showed significant decrease $(p<0.02)$ in lifethreatening experiences from the baseline to 12 months after garden construction.

3) Also included in the health assessment by nurses was the Trust/Safety subscale of the Social Capital Scale (SCS), which measures the effects of environmental change on trust and safety at the community scale. A paired t-test was utilized to show changes in mean scores in the Trust/Safety subscale from the baseline to 12 months post-garden construction. The analysis showed significant improvement $(p=0.01)$ in community trust and safety from the baseline to 12 months after garden construction. (See Social Cohesion benefit for discussion of the SCS as a whole.)

\section{Calculations:}

1) Post-project PIA Q5: "The projects have influenced security in your community..." $(n=23)$ 4 people responded " 5 " (much improved) ; $(4 / 23) * 100=17 \%$

7 people responded " 4 " ; $(7 / 23)^{*} 100=30 \%$

11 people responded " 3 " ; $(11 / 23) * 100=48 \%$

0 people responded " 2 " ; $(0 / 23)^{*} 100=0 \%$

1 person responded " 1 " (much degraded) ; $(1 / 23)^{*} 100=4 \%$

Total positive responses (4s and $5 \mathrm{~s}): 4+7=11 ;(11 / 23) * 100=48 \%$

Full methods and calculations for 1) and 2) published in Korn et al. 2018.

2) Summarized Life- Threatening Experiences (LTE) score:

Baseline ( $n=29)$ : mean score 2.0 (SD 1.7)

12 Months $(\mathrm{n}=26)$ : mean score 1.5 (SD 1.5)

Decrease in mean $=2.0-1.5=0.5(25 \%$ decrease in life threatening experiences $)$

Paired t-test $(n=26): p=0.02$

3) Summarized Trust/Safety domain score:

Baseline ( $n=29)$ : mean score 18.9 (SD 3.0)

12 Months $(n=26)$ : mean score 20.3 (SD 2.8)

Increase in mean $=20.3-18.9=1.4(6.9 \%$ increase in trust $/$ safety $)$

Paired t-test $(n=26): p=0.01$

Sources:

Surveyed household representatives' responses to PIA Q5 
Household representatives' responses to health assessment by nurses (see Korn et al, 2018)

Limitations: One limitation of the PIA and health assessments referenced in this benefit is the low $n$ value, which includes only adult household representatives and excludes the perspective of the teenagers that parents initially worried the local crime would affect. Teenagers in informal communities are prone to joining gangs and mafias as a source of income, community and stimulation and because of a lack of opportunity in life after school.

- Contributes to improved food security with $75 \%$ of 20 surveyed household representatives reporting that their home gardens improved their access to food. This provides the community with up to $\$ 250$ worth of fresh fruits, vegetables, and herbs per month.

Background: Food insecurity can be defined as having insufficient quantity or quality of food, reduced food intake, and/or feelings of shame, uncertainty or anxiety over food. Food insecurity can be linked to poor nutrition, development and growth especially among children, and is often associated with low educational attainment and the perpetuation of poverty (1). In Eliseo Collazos, $88 \%$ of households experienced at least some level of food insecurity, and $35 \%$ of families can be characterized as being severely food insecure (2). For these reasons, community members identified food security as a priority in community workshops. Living well below the poverty line and almost two hours from the city's central fresh food markets, it is extremely difficult for people living in Eliseo Collazos to maintain healthy diets. It is particularly difficult to include fruits, vegetables, and herbs in diets. Less healthy foods and beverages are often more affordable for people living in extreme poverty, which contributes to malnutrition that compounds other health issues to which people living in informal communities experience disproportionate risk. The coastal desert ecosystem where the community is situated receives less than $10 \mathrm{~mm}$ of rainfall each year, and public water supply is insufficient and unreliable even for drinking and household needs, limiting the possibility of community members cultivating fruits, vegetables and herbs closer to home before the project began.

The construction of household gardens not only provides an extremely affordable source of food, but it also raises the quality and diversity of the food that is accessible to community members. Productivity of household gardens is also an indicator of the success of the project in addressing water insecurity and the value of collected water, as demand for the fog water harvesting system largely stems from community demand for productive green space. The project added at least 81 types of edible plants, an 8 -fold increase in the number of edible plants in six months.

Method: Methods used to analyze food security include 1) and 2) 2 questions included in a PIA survey (see method 1 in Methods Overview), 3) a question included in the Garden Diaries (see method 3 in Methods Overview), and 4) plant counts conducted by the project team (see method 4 in Methods Overview): 
1) "The project of home gardens made your access to food..." Responses were one a scale of 1 to 5 , where $1=$ much worse and $5=$ much better. Responses were counted and total participants reporting positive responses ( $4 \mathrm{~s}$ and $5 \mathrm{~s}$ ) were added to find total participants reporting improvement. 20 out of 21 (95\% of) surveyed household representatives answered the question. Percentages were calculated based on an $n$ value of 20 .

2) "What is the main use (purpose) of the plants in your garden?" Possible responses included "food," "medicine," "decoration," "selling," and "other uses." Participating household representatives filled out this post-project PIA 3.5 years after the Phase I of household gardens was constructed and 1.5 years after Phase II, providing insight into the complex benefits of the gardens.

3) "What did you do with your harvest?" Beginning immediately after the construction of Phase I household gardens was complete, the illustrated Garden Diaries provided space each week for participating households to record whether they had harvested from their gardens and if so, what they did with their harvests; among choices, "ate," "sold," "traded," and "gifted." 26 out of the 29 households (90\%) that built Phase I household gardens. t participated in Garden Diaries, representing $43 \%$ of the total 60 households that built gardens overall (Phase I and Phase II) and $29 \%$ of households in Eliseo Collazos when the project finished.

4) Plant counts. The project team recorded what types of plants were planted in each of the 29 gardens planted in Phase I of the household gardens. Plant species were counted at the time of installation with follow up at 6 months and 3.5 years to monitor changes in plants over time. For this benefit, ornamental trees, flowers, and shrubs were excluded from the data set, and the number of different edible fruit tree species, edible fruiting vine species, herbs and vegetable species were counted at four different points in time: pre-garden construction, immediately after home gardens were planted, 6 months post-construction, and 3.5 years post-construction. Plants provided by the project team and plants added by community members were counted separately.

\section{Calculations:}

1) Post-project PIA Q4: "The project of home gardens made your access to food..." $(n=20)$ 4 people responded " 5 " (much improved) ; $(4 / 20) * 100=20 \%$

11 people responded " 4 " ; $(11 / 20)^{*} 100=55 \%$

5 people responded " 3 " ; $(5 / 20)^{*} 100=25 \%$

0 people responded " 2 " or " 1 "

Total positive responses (5s and $4 s): 4+11=15 ;(15 / 20)^{*} 100=75 \%$

2) Post-project PIA Q5: "What is the main use (purpose) of the plants in your garden?" $(n=19)$

10 participants checked "food" ; $(10 / 19) * 100=53 \%$

12 participants checked "medicine" ; $(12 / 19) * 100=63 \%$

14 participants checked "decoration" ; $(14 / 19) * 100=74 \%$

5 participants checked "selling" ; $(5 / 19) * 100=26 \%$

6 participants checked "other uses" ; $(6 / 19) * 100=32 \%$ 
3) Garden Diaries: "What did you do with your harvest?" (n=145 from 26 participating households)

97 participants checked "ate" ; $(97 / 145) * 100=67 \%$

11 participants checked "sold" ; (11/145)*100 $=8 \%$

8 participants checked "traded" ; $(8 / 145) * 100=6 \%$

20 participants checked "gifted" ; $(20 / 145) * 100=20 \%$

4) Plant counts: Types of edible plants in Phase I household gardens $(n=29)$ :

\begin{tabular}{|l|c|c|c|c|c|}
\hline \multicolumn{7}{|c|}{ edible plants by type and source over time $(\mathrm{n}=29)$} \\
\hline & fruit trees & fruit vines & vegetables & herbs & total \\
\hline Total different species & 11 & 2 & 21 & 15 & 81 \\
\hline $\begin{array}{l}\text { Pre-project edible } \\
\text { plants (9/2013) }\end{array}$ & 1 & 2 & 1 & 26 & 30 \\
\hline $\begin{array}{l}\text { Post-planting edible } \\
\text { plants (9/2013) }\end{array}$ & 27 & 9 & 69 & 102 & 207 \\
\hline $\begin{array}{l}\text { 6-months post-planting } \\
\text { edible plants (3/2014) }\end{array}$ & 32 & 4 & 120 & 88 & 244 \\
\hline $\begin{array}{l}\text { 3.5 years post-planting } \\
\text { edible plants (3/2017) }\end{array}$ & 56 & 9 & 33 & 89 & 187 \\
\hline
\end{tabular}

81 different species of edible plants were planted in Phase I of household gardens in the Fog Water Farm-Park \& Gardens project, including 11 types of fruit tree, 2 types of fruiting vine, 21 types of vegetables, and 15 types of herbs. Only 30 edible plants ( 1 fruit trees, 2 fruit vines, 1 vegetable and 26 herbs) existed at the 29 homes that participated in Phase I of household gardens before the project began. Immediately after the home gardens were constructed, the 29 gardens had 207 edible plants, including 27 fruit trees, 9 fruit vines, 69 vegetables, and 102 herbs representing 7 times more edible plant specimens than pre-project. These numbers grew over the following 6 months to a total of 244 edible plants after 6 months including 32 fruit trees, 4 fruit vines, 120 vegetables, and 88 herbs representing 8 times as many edible plant specimens as pre-project. After 3.5 years, the number of edible plant specimens reduced by $23 \%$ from counts at 6 months, representing 6 times more plants than pre-project. See limitations below for theories regarding this drastic drop in edible plant counts at 3.5 years. 


\begin{tabular}{|l|c|c|c|}
\hline \multicolumn{4}{|c|}{ Edible plant totals over time } \\
\hline & Total edible plants & $\begin{array}{c}\text { Change factor from } \\
\text { pre-project }\end{array}$ & $\begin{array}{c}\text { Change factor } \\
\text { from last count }\end{array}$ \\
\hline Pre-project & 30 & & 7 \\
\hline Post-project & 207 & 7 & 1 \\
\hline 6 months & 244 & 8 & 0.8 \\
\hline 3.5 years & 187 & 6 & \\
\hline
\end{tabular}

Cost estimate method: Garden Diaries (see method 3 in Methods Overview):

For a 14-week period, 16 out of 29 households that participated in Phase I of household gardens participated in illustrated Garden Diaries. Prompts relevant to this benefit include: "Did you harvest anything from your garden this week? If yes, what? If yes, how much?"

All responses were compiled into a table that lists all products, the number of times each of that product was harvested, and the number of specimens harvested in all of those harvests. Firm liaison and Lima native Coco Alarcón provided typical units and estimated local price per unit in USD for each garden product recorded in Garden Diaries. The value of each product was calculated as the number of units harvested multiplied by the estimated price per unit. The total approximate value of garden products for the 14-week period is equal to each of those products added together, a value of $\$ 252.30$ USD. See the table below for values and calculations.

\begin{tabular}{|c|c|c|c|c|c|}
\hline Item & Unit & $\begin{array}{c}\text { No. of } \\
\text { recorded } \\
\text { harvests }\end{array}$ & $\begin{array}{c}\text { Amount / } \\
\text { no. of } \\
\text { units } \\
\text { harveste } \\
\text { d }\end{array}$ & $\begin{array}{l}\text { Estimated } \\
\text { price per unit } \\
\text { (USD) }\end{array}$ & $\begin{array}{c}\text { Total value } \\
\text { (amount } \\
\text { harvested * } \\
\text { estimated } \\
\text { price per } \\
\text { unit) }\end{array}$ \\
\hline Hierbas/herbs & Bunch & 21 & 21 & $\$ 0.50$ & $\$ 10.50$ \\
\hline Culantro/cilantro & Bunch & 5 & 5 & $\$ 0.50$ & $\$ 2.50$ \\
\hline Cedrón/lemon verbena & Bunch & 4 & 4 & $\$ 0.50$ & $\$ 2.00$ \\
\hline Tes/teas & Bunch & 1 & 1 & $\$ 0.50$ & $\$ 0.50$ \\
\hline Rabinito/radish & Kilo & 6 & 10 & $\$ 3.00$ & $\$ 30.00$ \\
\hline Lechuga/lettuce & Head & 8 & 20 & $\$ 1.50$ & $\$ 30.00$ \\
\hline Papas/potato & $\begin{array}{l}15, \\
\text { Quart }\end{array}$ & 4 & 18 & $\$ 1.50$ & $\$ 27.00$ \\
\hline Cebolla Chinese/green onion & Bunch & 2 & 2 & $\$ 0.80$ & $\$ 1.60$ \\
\hline Cebolla/onion & Kilo & 2 & 4 & $\$ 1.20$ & $\$ 4.80$ \\
\hline
\end{tabular}




\begin{tabular}{|l|l|c|c|c|c|}
\hline Zanahoria/carrot & Unit & 7 & 205 & $\$ 0.30$ & $\$ 61.50$ \\
\hline Perejil/parsley & Bunch & 3 & 3 & $\$ 0.80$ & $\$ 2.40$ \\
\hline Tomate/tomato & Kilo & 5 & 6 & $\$ 2.00$ & $\$ 12.00$ \\
\hline Poro/leek & Kilo & 1 & 1 & $\$ 1.00$ & $\$ 1.00$ \\
\hline Chala/corn & Unit & 2 & 2 & $\$ 1.00$ & $\$ 2.00$ \\
\hline Arveja/pea & Quart & 6 & 7 & $\$ 4.00$ & $\$ 28.00$ \\
\hline Huacatay/Tagetes minuta-black mint & Bunch & 1 & 1 & $\$ 0.60$ & $\$ 0.60$ \\
\hline Papaya & Unit & 1 & 1 & $\$ 2.00$ & $\$ 2.00$ \\
\hline Espinaca/spinach & Bunch & 2 & 2 & $\$ 1.40$ & $\$ 2.80$ \\
\hline Beterraga/beet & Kilo & 2 & 2 & $\$ 1.50$ & $\$ 3.00$ \\
\hline Toronjil/lemon balm & Bunch & 4 & 4 & $\$ 0.60$ & $\$ 2.40$ \\
\hline Manzanilla/chamomile & Branch & 3 & 3 & $\$ 1.00$ & $\$ 3.00$ \\
\hline Mora/type of leafy green & n/a & 1 & 1 & $\mathrm{n} / \mathrm{a}$ & $\mathrm{n} / \mathrm{a}$ \\
\hline Anís/anis & Kilo & 1 & 1 & $\$ 3.00$ & $\$ 3.00$ \\
\hline Habas/fava beans & Kilo & 2 & 2 & $\$ 2.00$ & $\$ 4.00$ \\
\hline Flores/flowers & Unit & 8 & 9 & $\$ 1.00$ & $\$ 9.00$ \\
\hline Caihua/Cyclanthera pedata-squash & Unit & 1 & 1 & $\$ 1.00$ & $\$ 1.00$ \\
\hline Rosas/rose & Unit & 1 & 3 & $\$ 1.50$ & $\$ 4.50$ \\
\hline Palta/avocado & Unit & 1 & 1 & $\$ 1.20$ & $\$ 1.20$ \\
\hline unspecified & n/a & 3 & 3 & $\mathrm{n} / \mathrm{a}$ & $\mathrm{n} / \mathrm{a}$ \\
\hline Total (n=26 gardens x 14 weeks) & & & & & $\$ 252.30$ \\
\hline
\end{tabular}

Estimated value of produce harvested in 26 home gardens over 14 weeks

Sources:

Surveyed household representatives' responses to PIA Q4

Garden Diaries by residents

Plant counts by project team

(1) Coates, Jennifer, Anne Swindale and Paula Bilinsky. 2007. Household Food Insecurity Access Scale (HFIAS) for Measurement of Household Food Access: Indicator Guide (v. 3).

Washington, D.C.: FHI 360/FANTA.

(2) Isquith-Dicker, L., \& Shell-Duncan, Bettina. (2016). Food security and social capital in an urban informal settlement in Lima, Peru. Seattle]: University of Washington. 
Limitations: Garden Diaries were conducted for four months after initial construction including the tail end of the foggy season. This presents several limitations. First, many vegetables (beets, lettuce, carrots, radishes) were grown from seeds and may not have reached maturity in time to harvest in the time period captured in the Garden Diaries. Similarly, freshly planted fruit trees or vines would not have had time to mature enough to produce fruits. To gain a more complete picture of the food yields being produced in household gardens, Garden Diaries would require regular follow-ups, as well as follow-up to the information provided in the maintenance manual about seed saving or other re-seeding of annual plants. See Appendix 4: Gardens Maintenance Manual for more details. (The plant counts by project team in-part makes up for this limitation.)

Second, the Garden Diaries only capture a continuous 14-week window during which plant growth is heavily influenced by the foggy season, and should not be generalized over a year. Third, the Garden Diaries likely show much lower yields than reality, as several households skipped several weeks of entries, especially toward the end of the 14-week period. Lastly, while the capture of Garden Diaries is high for the first round of gardens, including 26 out of the 29 households that participated in round 1, the Garden Diaries do not represent the 31 households that participated in Round 2 of household garden construction.

Limitations associated with plant counts by project team include similar point-in-time limitations to garden diaries with regards to annual edible plant species whose life spans may be shorter than six months; for example, if a head of lettuce was harvested within 5 months of home garden construction, that plant would not be included in the 6-month plant count; the six-month plant counts both reflect unwanted plant death and plants with shorter life spans. A major limitation of the 3.5 year plant count is the Lima-wide water crisis of March 2017. The project team just happened to have this window to conduct these field measurements, which were likely far lower than even one month before, since the entire city of Lima had water shut off for a two week period due to extreme flooding. While Eliseo Collazos was better prepared for this crisis than other communities through water stored from the fog water harvesting system, water was allocated to immediate household needs during this time. Furthermore, April is the end of the dry season in Lima, posing a harsh environment to plants from whom water was diverted during the water crisis.

\section{- Improves community beauty, with $100 \%$ of 20 surveyed household representatives reporting that their home gardens contribute to improved aesthetic quality.}

Background: The Fog Water Farm-Park \& Gardens project differs from many client-initiated projects in which aesthetic improvement tends to be among top priorities in that its features are in direct response to needs and priorities established by community members. Despite principal aims to address a host of other priorities (access to green space, water, and other public healthpromoting features), the project was not without its improvements to aesthetic beauty. Improved beauty and an appreciation for the beauty that new green spaces created were among common themes in participant responses to open-ended questions in post-project PIA questionnaires. 
Method: Methods include 1) and 2) two questions included in PIA surveys (see method 1 in Methods Overview):

1) "How do you feel about how your community looks (aesthetics)?" This general question was asked both pre- and post-project implementation. Responses were on a scale of 1 to 6 , where 1 = very happy and 6 = very unhappy. Responses were averaged both pre-project and postproject. The post-project average was subtracted from the pre-project average to find change. A difference ranging from 0 to .9 was considered minor improvement; a change of 1 or higher was considered significant improvement. 18 and 16 household representatives participated in the pre- and post-project PIAs, respectively, representing $22 \%$ and $20 \%$ of households in Eliseo Collazos when the project started.

2) "The project of home gardens made the community look (aesthetics)..." Responses were on a scale of 1 to 5 , where $1=$ much worse and $5=$ much better. Responses were counted and total positive responses ( $4 \mathrm{~s}$ and $5 \mathrm{~s}$ ) were added to find total participants reporting improvement. 20 out of 21 (95\% of) surveyed household representatives answered the question. Percentages were calculated based on an $n$ value of 20 , representing $33 \%$ of the 60 total households that built home gardens.

\section{Calculations:}

1) Pre- and post-project PIA Q2: "How do you feel about how your community looks (aesthetics)?"

Pre-project PIA ( $\mathrm{n}=18)$

11 people responded "1" (very happy)

1 person responded " 2 "

5 people responded " 3 "

1 person responded " 4 "

0 people responded " 5 "

0 people responded "6" (very unhappy)

$\left(\left[11^{*} 1\right]+\left[1^{*} 2\right]+\left[5^{*} 3\right]+\left[1^{*} 4\right]\right) / 18=32 / 18=1.78$ average

Post-project PIA ( $n=16)$

9 people responded " 1 " (very happy)

2 people responded " 2 "

2 people responded " 3 "

3 people responded " 4 "

0 people responded " 5 "

0 people responded " 6 " (very unhappy)

$\left(\left[9^{\star} 1\right]+\left[2^{\star} 2\right]+\left[2^{\star} 3\right]+\left[3^{*} 4\right]\right) / 16=31 / 16=1.94$ average

$1.78-1.94=-0.16 ;$ minor worsen 
2) Post-project PIA Q4: "The project of home gardens made the community look (aesthetics)..." $(n=20)$

11 people responded " 5 " (much improved) ; $(4 / 20) * 100=55 \%$

9 people responded " 4 " ; $(11 / 20)^{*} 100=45 \%$

0 people responded " 3 ," "2," or " 1 "

Total positive responses (5s and $4 \mathrm{~s}): 11+9=20 ;(20 / 20)^{*} 100=100 \%$

Sources: Surveyed household representatives' responses to PIA Q2 and Q4

Limitations: The pre- and post-project PIA Q2 question described in methods showed a minor worsening of how participating household representatives felt about the aesthetics of the community, despite $100 \%$ of participating household representatives reporting that the home gardens improved community aesthetics. This may speak to higher aspirations for community beauty that community members could have developed over the course of project implementation, or to an expectation for aesthetic change that was not quite met. Limitations of the study is understanding the context of their responses; a complementary qualitative analysis could have helped address this limitation.

- Enhances community satisfaction with access to green spaces, with $29 \%$ of surveyed household representatives being happy with their access to green spaces pre-project improving to $91 \%$ post-project. Additionally, $78 \%$ of 23 surveyed household representatives agreed that the fog collection system and community farm-park improved their access to green spaces.

Background: Community members identified access to greenspace as a top priority in participatory workshops, which they define as both planted green areas and recreational green spaces such as the sports field and play areas. In the pre-project PIA, the average level of happiness among 23 participating household representatives was 3.33 on a scale of 1 to 6 , where 1 = very happy and 6 - very unhappy. The number improved to 1.52--happy--in postproject PIAs conducted after all project phases had been completed.

Method: Methods include 1) and 2) two questions included in PIA surveys (see method 1 in Methods Overview):

1) "How do you feel about your access to parks and gardens (green spaces)?" This general question was asked both pre-and post-project implementation. Responses were on a scale of 1 to 6 , where $1=$ very happy and $6=$ very unhappy. Responses were averaged both pre-project and post-project. The post-project average was subtracted from the pre-project average to find change. A difference ranging from 0 to .9 was considered minor improvement; a change of 1 or higher was considered significant improvement. 24 and 22 household representatives participated in the pre- and post-project PIAs, respectively, representing $29 \%$ and $27 \%$ of households in Eliseo Collazos when the project started. 
2) "The fog collection and park made access to green spaces..." Responses were on a scale of 1 to 5 , where $1=$ much worse and $5=$ much better." Responses were counted and total positive responses ( $4 \mathrm{~s}$ and $5 \mathrm{~s}$ ) were added to find total participants reporting improvement. 23 out of 23 ( $100 \%$ of) surveyed household representatives answered the question. Percentages were calculated based on an $n$ value of 23 , representing $28 \%$ of the households in Eliseo Collazos when the project started.

\section{Calculations:}

1) Pre- and post-project PIA Q1: "How do you feel about your access to parks and gardens (greenspaces)?"

Pre-project PIA $(n=24)$

6 people responded " 1 " (very happy)

1 person responded " 2 "

7 people responded " 3 "

2 people responded " 4 "

5 people responded " 5 "

3 people responded " 6 " (very unhappy)

$\left(\left[6^{*} 1\right]+\left[1^{*} 2\right]+\left[7^{*} 3\right]+\left[2^{*} 4\right]+\left[5^{*} 5\right]+\left[3^{*} 6\right]\right) / 24=80 / 24=3.33$ average

Total positive responses ( 1 s and $2 \mathrm{~s}$ ): $6+1=7 ; 29 \%$ happy or very happy

Post-project PIA ( $\mathrm{n}=22)$

13 people responded " 1 " (very happy)

7 people responded " 2 "

2 people responded " 3 "

0 people responded " 4 "

0 people responded " 5 "

0 people responded " 6 " (very unhappy)

$\left(\left[13^{*} 1\right]+\left[7^{*} 2\right]+\left[2^{*} 3\right]\right) / 22=33 / 22=1.5$ average

Total positive responses ( $1 \mathrm{~s}$ and $2 \mathrm{~s}$ ): $13+7=22 ; 91 \%$ happy or very happy

$3.33-1.5=1.83 ;$ significant improvement

$29 \%$ (pre-project) to $91 \%$ (post-project) happy or very happy

2) Post-project PIA Q3- "The fog collection and park made access to green spaces..." $(n=23)$

7 people responded " 5 " (much better) ; $(7 / 23)^{*} 100=30 \%$

11 people responded " 4 " (somewhat better) ; $(11 / 23)^{*} 100=48 \%$

5 people responded "3" (no change) $;(5 / 23)^{\star} 100=22 \%$

0 people responded " 2 "(somewhat worse) or " 1 " (much worse)

Total positive responses $(5 \mathrm{~s}$ and $4 \mathrm{~s}): 7+11=18 ; 30 \%+48 \%=78 \%$

Sources: Surveyed household representatives' responses to PIA Q3 and Q1

Limitations: The PIA questionnaires from which these responses come were specifically focused 
on the fog harvesting and community farm-park features of the project, while excluding home gardens that provided additional public-private access to green space for individual families.

- Increased green space per capita in the community of Eliseo Collazos from 0 to approximately 1.776 sq meters (19.12 sf), bringing the marginalized community about halfway to Lima's average of 3.9 sq meter per capita and nearly one sixth of the way toward achieving the WHO-recommended 9 to 12 sq meters (41.98 sf) per capita.

Background: Access to green space is extremely limited in informal communities, posing disproportionate risk of physical and mental health and well-being for people and their families (1). Access to green space is an increasingly important indicator of human and ecological health for urban communities, and green space per capita is an important tool for understanding this access and setting goals toward improving conditions for urban dwellers. A 2018 report of urban indicators in Peru published statistics for green space per capita for Peru's 26 largest cities. According to the report, Lima, Peru has the highest amount of green space per capita out of all Peruvian cities with $3.9 \mathrm{~m}^{2}$ per capita, yet still only about one third of the World Health Organization (WHO) recommended 9-12 $\mathrm{m}^{2}$ per capita (1). In addition this green space is not equitably distributed in Lima, and poor and informal communities include almost none of this green space.

In community workshops, Eliseo Collazos community members agreed on access to green space as a top priority. Understanding this priority in the context of scaled green space per capita stats highlights the importance of grounding efforts toward healthy landscape in international standards of and grounds the Farm-Park and Gardens Project in a larger discussion of green space as an indicator of urban community health. Among common themes that participants mentioned in post-project PIA questionnaires were the benefits that new green spaces provided, including shade and higher-quality air.

\section{Methods:}

Methods include 1) use of photo documentation (see method 6 in Methods Overview) as well as construction plans and home gardens materials lists:

Community members defined green spaces as outdoor green or recreation spaces designed for either public or public-private use (because household gardens were installed in the front of houses, the continuous line of gardens along the street created a public-private greenspace). Areas of home gardens were estimated through photos and known linear meters of border fences. Area of the sports field was given, and was multiplied by three to estimate the total usable area including the sports field, terraced farm-park, seating areas, stairway, and cisterns, based on aerial imagery. Calculated areas were compared to statistics presented in Peru's First National Report on Urban Indicators from 2018 (1). 
Calculations:

Area of home gardens:

60 gardens * $2 \mathrm{~m} 2=120 \mathrm{~m}^{2}$

Area of farm-park:

$10 \mathrm{~m} \times 18.5 \mathrm{~m}$ sports field $=185 \mathrm{~m}^{2}$

$185 \mathrm{~m} 2 \times 3=555 \mathrm{~m}^{2}$

Total green space:

$120 \mathrm{~m}^{2}$ home gardens $+555 \mathrm{~m}^{2}$ farm-park $=675 \mathrm{~m}^{2}$

Green space per capita in Eliseo Collazos:

$675 \mathrm{~m} 2$ / approx. 380 community members $=1.776 \mathrm{~m}^{2}\left(19.12 \mathrm{ft}^{2}\right)$ per capita

Compare to Lima average $3.9 \mathrm{~m}^{2}$ per capita:

$3.9 \mathrm{~m}^{2} / 1.776 \mathrm{~m}^{2}=2.19$

Lima average is 2.19 times higher, thus green space per capita in Eliseo Collazos is nearly halfway to Lima average.

Compare to WHO-recommended $9-123.9 \mathrm{~m}^{2}$ per capita:

$([9+12] / 2)=10.5 \mathrm{~m}^{2}$ (average for WHO's recommended range) $/ 1.776 \mathrm{~m}^{2}=5.9$

The WHO recommended green space per capita is nearly 6 times higher, thus green space per capita in Eliseo Collazos is 1/6th of the way toward achieving the WHO's recommendation for green space per capita.

\section{Sources:}

1. Frumkin H., Bratman G.N., Breslow S.J., Cochran B., Kahn P.H.Jr., Lawler J.J., Levin P.S., Tandon P.S., Varanasi U., Wolf K.L., et al. Nature contact and human health: A Research Agenda. Environ. Health Perspect. 2017;125:075001. doi: 10.1289/EHP1663.

2. Zucchetti, A., \& Freundt, D. (2018). Ciudades del Perú: Primer Reporte Nacional de Indicadores Urbanos 2018. Retrieved from Perú:

\section{Limitations:}

Exact square meters of home gardens are difficult to calculate, as some residents spread their garden materials out around their homes. For example, a bench may be on one side of the house, a planter and path on another, and a planting bed on yet another. Estimates based on fenced or walled planted areas only. Green space is measured differently in different places globally. Residential gardens are typically not included in conventional urban green space totals as they were here. The choice to include the household gardens was based on the fact that all but one garden was placed in the front of the house, contributing to continuous greening along the public street, enjoyed by all in the community. 


\section{Economic Benefits}

- Supports increased financial stability, with $45 \%$ of 44 surveyed household representatives reporting improvement in their financial situation due to the project.

Background: Along with the approximately $30 \%$ (roughly 3 million people) living in informal settlements in Lima, people living in Eliseo Collazos live in poverty, and the informal community is neglected by public funding. Among 44 participants in a study that aimed to measure the effects of household gardens on a variety of health and well-being measures, 13 study participants reported an income from 0 to 374 soles (extreme poverty), 22 reported income in the range 375 to 749 soles, and 8 reported income in the range $750-1,500$ soles (1). According to INEI, the minimum monthly living wage in Peru is defined as $\$ 415$ USD per month, which is just under 1,500 soles, and those with an income of $\$ 85$ USD, approximately 300 soles per month, are living in extreme poverty (2).

Method: Methods include a question included in a PIA survey (see method 1 in Methods Overview):

"The projects have influenced your financial situation..." Responses were on a scale of 1 to 5 , where $1=$ much worse and $5=$ much better. Responses were counted and total participants reporting positive responses ( $5 \mathrm{~s}$ and $4 \mathrm{~s}$ ) were added to find total participants reporting improvement. 22 out of 23 (96\% of) surveyed household representatives answered the question. Percentages were calculated based on an $n$ value of 22 , representing $27 \%$ of households in Eliseo Collazos when the project started.

\section{Calculations:}

Post-project PIA Q5: "The projects have influenced your financial situation..." $(\mathrm{n}=22)$

3 people responded " 5 " (enhanced) ; $(5 / 22)^{*} 100=14 \%$

7 people responded " 4 " (somewhat enhanced) ; $(7 / 22) * 100=32 \%$

12 people responded "3" (no change); $(12 / 22) * 100=55 \%$

0 people responded "2"(somewhat worse) or " 1 " (much worse)

Total positive responses ( 5 s and $4 s): 3+7=10 ; 14 \%+32 \%=45 \%$

Sources: Surveyed household representatives' responses to PIA Q5

1. Korn et al. 2018

2. Instituto Nacional de Estadística e Informática (INEI) 2012, Peru. Retrieved from https://www.inei.gob.pe/media/MenuRecursivo/publicaciones digitales/Est/Lib1106/inde $\underline{x . h t m l}$

Limitations: Question wording in the PIA does not capture the nuanced reasons why or how 
financial situations may have been affected. Improvements may be from reduced need to buy food and medicinal plants, augmenting the benefit of improved nutrition through access to more nutritious ingredients that were previously unaffordable. Answers could also reflect feelings of overall higher quality of life or increased satisfaction with homes and community spaces. A follow-up question asking how the financial situation was affected (or not affected) could offer further insight.

\section{Unquantified Benefits}

Anecdotal successes illustrate the far-reaching benefits of the project:

- Children appear to have benefited significantly from growing up participating in and watching their parents participate in the Fog Water Farm-Park and Gardens Project. For example, one child won first place in their school's science fair for a fog and gardens technology project.

- Adults benefitted from skills-building opportunities including construction workshops, masonry observations, and gardening demonstrations and construction participation that will likely guide them through maintenance of their homes, gardens, and community for years to come, while also potentially providing employable job skills.

- Residents of Eliseo Collazos who participated in a short documentary reported that gardens were providing the community with cleaner air.

\section{Features - Additional Information}

- Saved an estimated \$50 USD, about 175 soles, on construction materials as well as transportation costs and fossil fuel emissions by harvesting $\mathbf{2 5}$ sq meters of stone material for home gardens from site and surrounding area.

Background: The cost of materials is a major barrier to construction of gardens and beautification of the community, which lives far below the poverty line; families do not have disposable income even for relatively cheap materials such as landscape stone.

Method: Estimated volume of rock used in community gardens and multiplied by an estimated price of stone landscaping material.

Calculations: About $.5 \mathrm{sq}$ meters of stone used in each household garden ${ }^{*} 50$ gardens $=25 \mathrm{sq}$ meters.

25 sq meters stone ${ }^{*} \sim \$ 2$ USD $=\sim \$ 50$ in cost savings. 
Sources: Project materials lists; Coco Alarcón for price estimates

Limitations: Does not include estimated transport cost, as location purchased and transport method used vary greatly.

\section{Sources and References, Awards, Exhibitions}

Physical and Mental Health Impacts of Household Gardens in an Urban Slum in Lima, Peru

Link to article on the web

Korn, A., Bolton, S. M., Spencer, B., Alarcon, J. A., Andrews, L., \& Voss, J. G. (2018). Physical and Mental Health Impacts of Household Gardens in an Urban Slum in Lima, Peru. International Journal of Environmental Research and Public Health, 15(8), 1751. doi:10.3390/ijerph15081751

\section{Improved Fog Collection Using Turn Reinforcement Mats}

Link to article on the web

Feld, S. I., Spencer, B. R., \& Bolton, S. M. (2016). Improved Fog Collection Using Turf Reinforcement Mats. Journal of Sustainable Water in the Built Environment, 2(3). doi:10.1061/JSWBAY.0000811

"The Informal Urban Communities Initiative: Lomas de Zapallal, Lima, Peru" from Now Urbanism Link to book on web

Spencer, B., Bolton, S., \& Alarcón, J. (2015). The Informal Urban Communities Initiative: Lomas de Zapallal, Lima, Peru. In Jeffrey Hou, Benjamin Spencer, Thaisa Way, \& K. Yocom (Eds.), Now Urbanism: The Future City is Here (pp. 206-223). New York, NY: Routledge.

Whole-Systems Public Interest Design Education - Chapter 1

"Whole-Systems Public Interest Design Education: Department of Landscape Architecture, University of Washington." In Bryan Bell and Lisa Albendroth (Eds.). Public Interest Design Education Guidebook: Curricula, Strategies, and SEED Academic Case Studies. Book to be published by Routledge.

Innovations in Landscape Architecture - Chapter 17 Emergent Convergent Spencer, Ben and Susan Bolton. 2016. "Emergent Convergent: Technology and the Informal Urban Communities Initiative". In Daniel Ortega and Jonathan Anderson (Eds.). Innovations in Landscape Architecture. Routledge, UK. pp. 205-222.

Community-driven Design in the Slums of Lima, Peru - International Journal of Service Learning in Engineering

Spencer, Ben, Susan Bolton and Jorge Alarcon. 2014. "The Informal Urban Communities Initiative, Community-driven design in the Slums of Lima, Peru." International Journal of Service Learning in Engineering, $\quad$ 9(1): 92-107.

\section{Design as Preventive Medicine}

Andrews, Leann and Ben Spencer. 2014. "Design as Preventive Medicine." In Evert, J., Drain, P., and Hall, T. (Eds.). Developing Global Health Programming: A Guidebook for Medical 
and Professional Schools, Second

Press. P. 274-277.
Edition. Schools. Global Health Education Collaboration

\section{Awards:}

National American Society of Landscape Architects (ASLA) Student Honor Award in Community Service. For Gardens, Greenspace and Health in Lomas de Zapallal. 2014. Featured in Landscape Architecture Magazine, October 2014, Vol 104. No 10. 84.

Public Interest Design Global Project Winner. Ecole Spécial d'Architecture, Paris, Design Corps and the SEED Network. International, 6 awards annually. Receiving the highest number of jury votes of any project submitted, according to competition organizers. For Comunidad Ecologica Saludable including the Gardens Green Space and Health and SQWater: Fog Collection projects. 2014.

Social Economic and Environmental Design (SEED) Award. Parsons New School of Design, Design Corps, the SEED Network. International, 6 awards annually. Receiving the highest number of jury votes of any project submitted, according to competition organizers. For Communicad Ecologica Saludable including the Gardens Green Space and Health and SQWater: Fog Collection projects. 2014.

2nd Place, ACSE Sustainable Development Award. American Society of Civil Engineers and Engineers Without Borders USA. National, annually. For SQWater: Fog Collection. 2013.

Finalist, EPA P3 Competition. United States Environmental Protection Agency. National, annually. For SQWater: Fog Collection. 2013.

\section{Conferences and exhibits (incomplete list):}

University of Washington BE Boundless, for Washington, for the World Campaign. The Informal Urban Communities Initiative. IUCI selected as the University of Washington's featured project for one month in 2017 to headline the University of Washington BE Boundless Capital Campaign.

"Informal Urban Communities Initiative: Taking Design Activism to Scale, Slowly". To be presented at the 2017 Council of Educators in Landscape Architecture Conference: Bridging. Beijing, China, May 26-29, 2017.

“Fog Water Farms” Museum of London. City Now/City Future Season/Exhibition. May 2017- April 2018.

"Agua Gratis - Area Verdes Comunidades Saludablesa" Expo Agua Perú. Centro de Exposiciones "EI Vivero" del Jockey Club. Lima, Peru. October 19-21, 2016. 


\section{Appendices}

\section{Research Instruments}

Appendix 1: Participatory Impact Assessment (PIA) Post Project Evaluation Questionnaire Appendix 2: Mental Health and Quality of Life Questionnaire with WHO Scoring Instructions Appendix 3: Garden Diaries

\section{Construction and Maintenance Manuals}

Appendix 4: Household Gardens Maintenance Manual

Appendix 5: Fog Collectors Maintenance Manual

Appendix 6: Fog System and Farm Park Maintenance Manual

\section{Project Images}

Appendix 7: Project Overview

Appendix 8: Example of Household Garden Evolution 2013-2020 


\section{Research Instruments}

Appendix 1: Participatory Impact Assessment (PIA) Post Project Evaluation Questionnaire 
$\square$ Hombre

$\square$ Mujer

Edad:

¿Participó en la construcción? $\square$ Sí $\square$ No

Marque con una $X$ en la carita que refleja mejor su estado de ánimo y responda las preguntas que corresponda

1A. ¿Cómo se siente acerca de su situación con el agua?
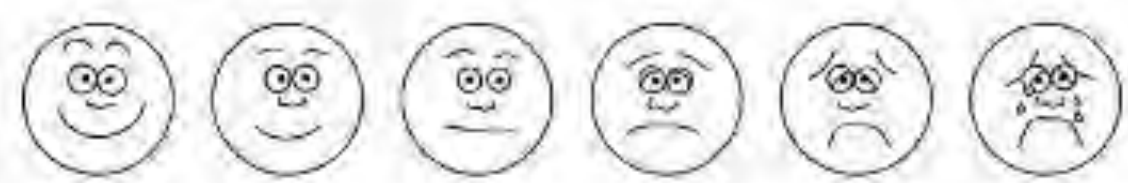

1B. En el último año y medio, ¿Qué cambios en la comunidad han influenciado en su situación con el agua?

2A. ¿Cómo se siente acerca de su acceso de parques y jardines?
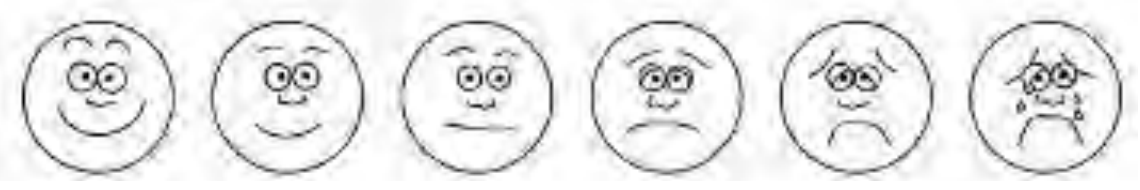

2B. En el último año y medio, ¿Qué cambios en la comunidad han influenciado en su acceso a parques y jardines 
3A. ¿Cómo se siente acerca del mantenimiento y distribución del agua en su comunidad?
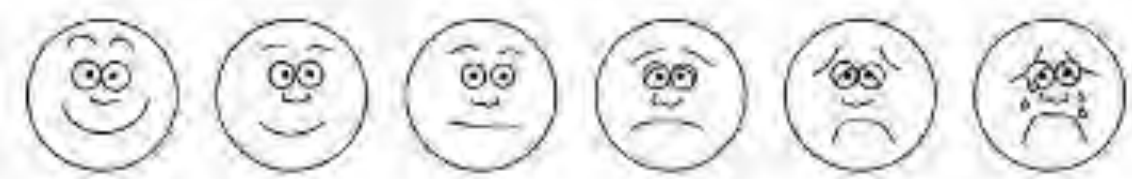

3B. En el último año y medio, ¿Qué cambios en la comunidad han influenciado en el mantenimiento y distribución del agua en su comunidad?

4A. ¿Cómo se siente acerca de la situación de mosquitos es la comunidad?
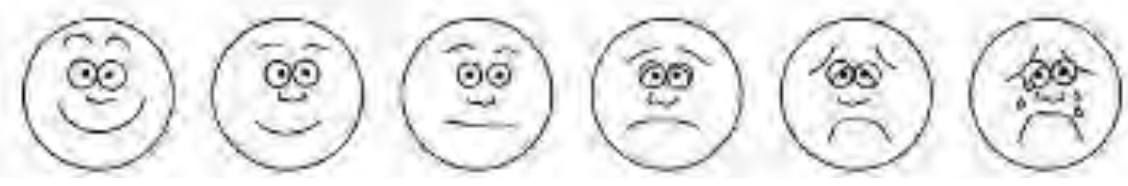

4B. En el último año y medio, ¿Qué cambios en la comunidad han influenciado en la situación de mosquitos en la comunidad?

5A. ¿Cómo se siente acerca de su gasto de dinero en agua?
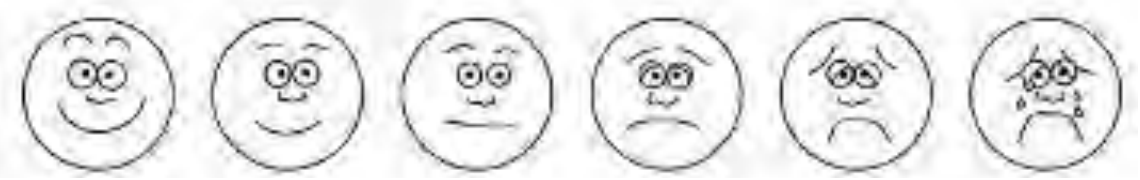

6B. En el último año y medio, ¿Qué cambios en la comunidad han influenciado en su gasto de dinero en agua? 
$\square$ Hombre

$\square$ Mujer Edad:

¿Participó en la construcción? $\square$ Sí $\square$ No

Marque con una $X$ en la carita que refleja mejor su estado de ánimo y responda las preguntas que corresponda

1A. ¿Cómo se siente acerca de su salud mental, felicidad y bienestar?
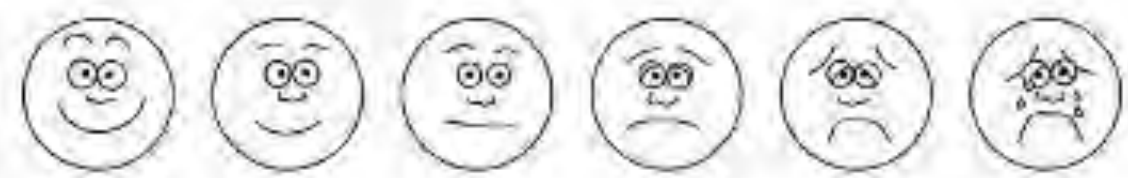

1B. En el último año y medio, ¿Qué cambios en la comunidad han influenciado en su salud mental, felicidad y bienestar?

2A. ¿Cómo se siente acerca de su acceso a alimentos y comida?
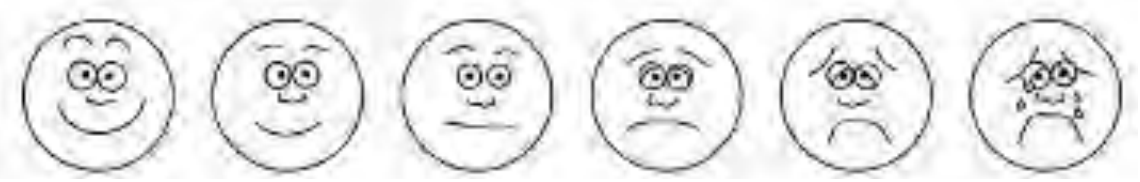

2B. En el último año y medio, ¿Qué cambios en la comunidad han influenciado el acceso a alimentos y comida? 
3A. ¿Cómo se siente acerca del medio ambiente en su comunidad?

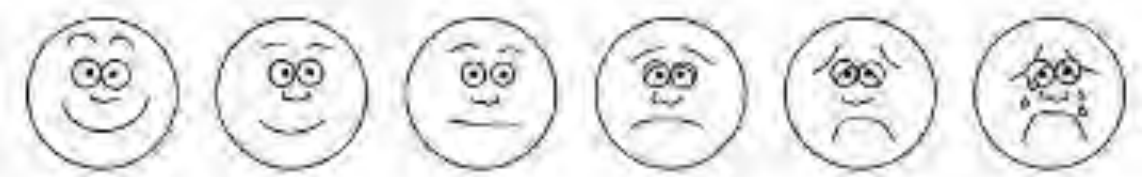

3B. En el último año y medio, ¿Qué cambios en la comunidad han influenciado en el medio ambiente de su comunidad?

4A. ¿Cómo se siente acerca de cómo se ve su comunidad?

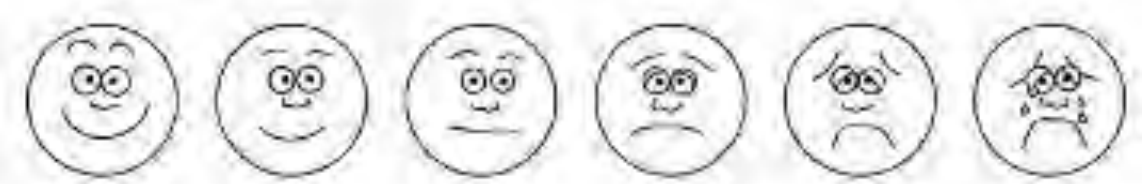

4B. En el último año y medio, ¿Qué cambios en la comunidad han influenciado en cómo se ve su comunidad?

5A. ¿Cómo se siente acerca la calidad de vida en su comunidad?

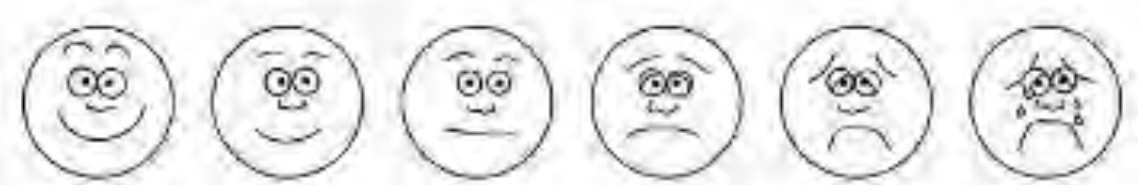

5B. En el último año y medio, ¿Qué cambios en la comunidad han influenciado la calidad de vida en la comunidad? 
\begin{tabular}{l|l|l}
$\begin{array}{l}\square \text { Hombre } \\
\square \text { Mujer }\end{array}$ & Edad:___ ¿Participó en la construcción? $\square$ Sí $\square$ No
\end{tabular}

Marque con una $X$ en el dibujo que refleja mejor su opinión y responda las preguntas que corresponda

1 Los atrapanieblas y el parque han hecho que el acceso al agua sea ...

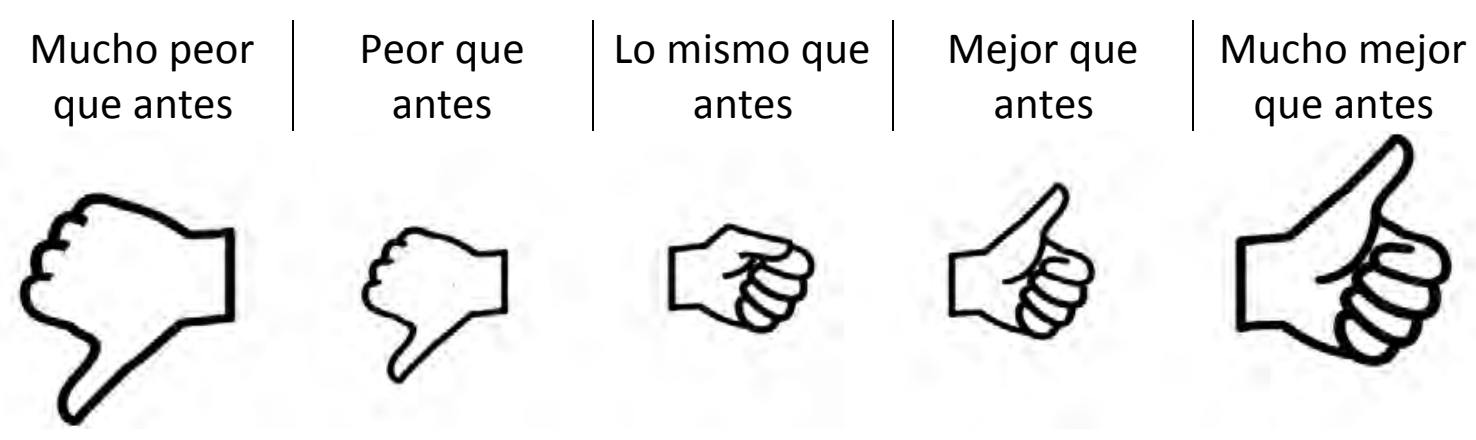

2 Los atrapanieblas y el parque han hecho que el acceso al agua a áreas verdes sea ...

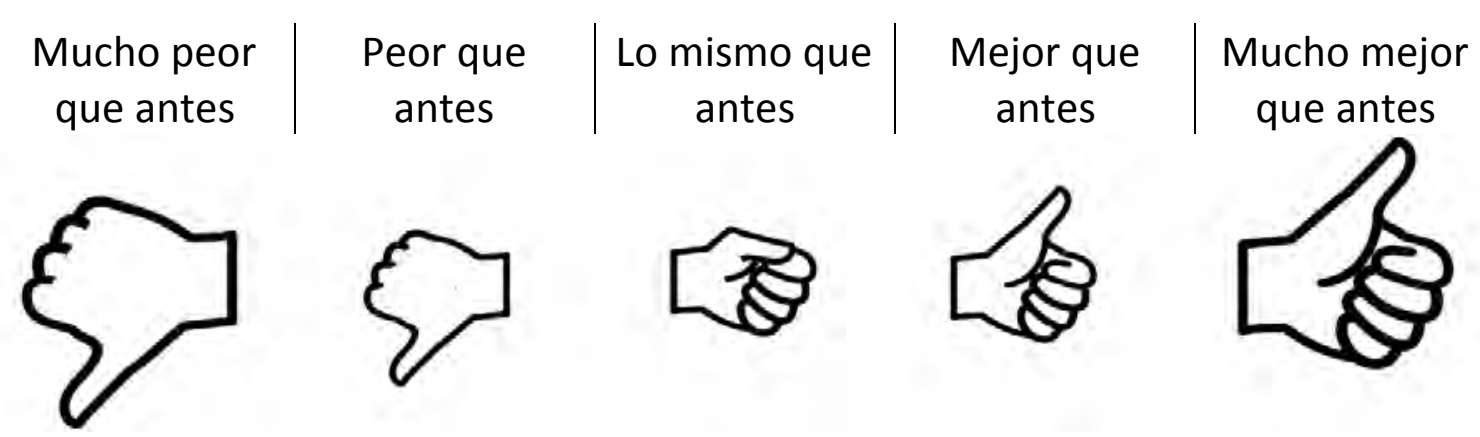

3 Los atrapanieblas y el parque han hecho que el mantenimiento y distribución de agua sea

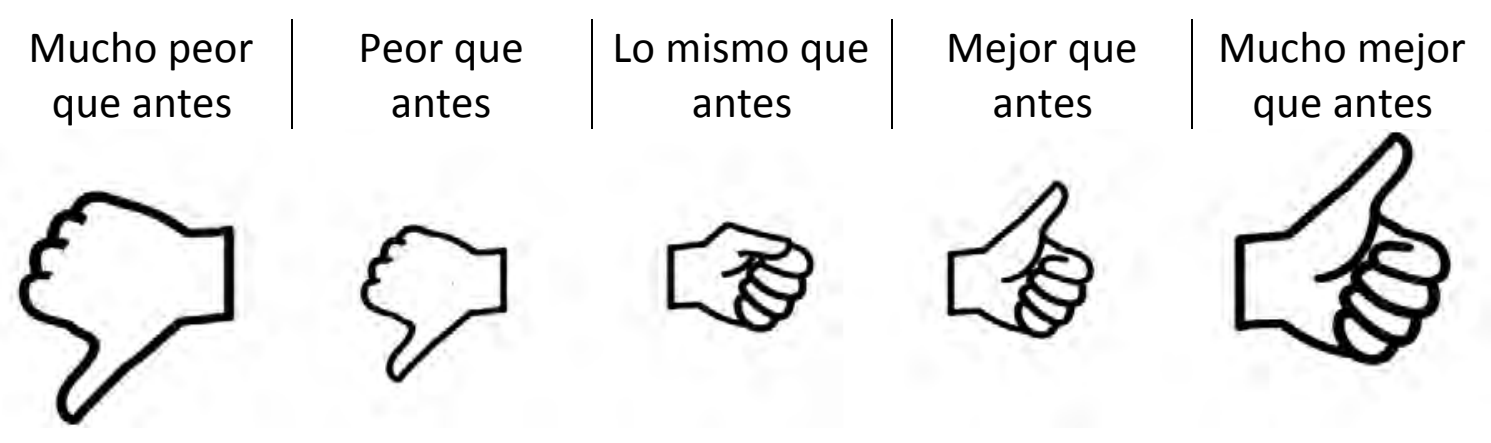


4 Los atrapanieblas y el parque han hecho que el problema de mosquitos sea ...

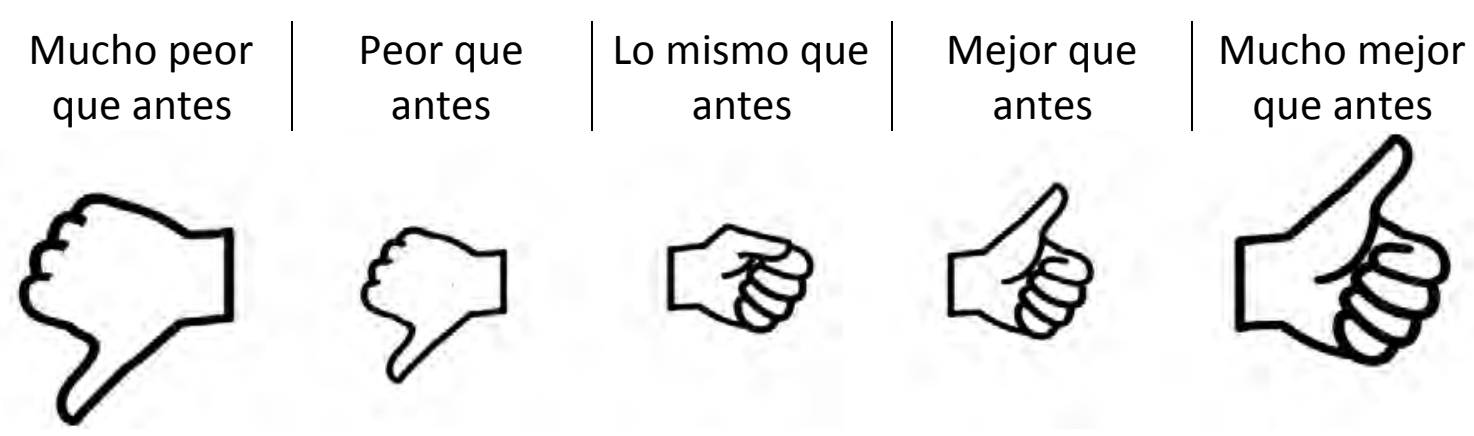

5 Los atrapanieblas y el parque han hecho que el costo del agua sea ...

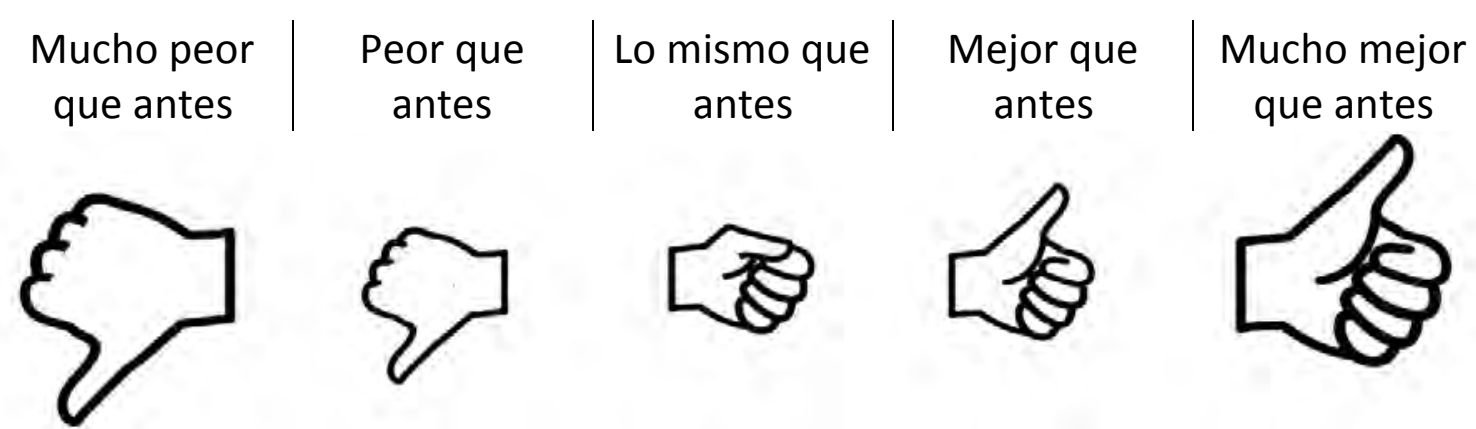

6 ¿Qué es lo que más te desagrada (lo que menos te gusta) de los atrapanieblas y el parque?

7 ¿Qué es lo que más te agrada (lo que más te gusta) de los atrapanieblas y el parque?

8 ¿Hay algo que quieras comentarnos o compartir sobre los atrapanieblas y el parque? 
\begin{tabular}{l|l|l}
$\square$ Hombre \\
$\square$ Mujer
\end{tabular} \mid Edad:__Participó en la construcción? $\square$ Sí $\square$ No

Marque con una $X$ en el dibujo que refleja mejor su opinión y responda las preguntas que corresponda

1 El proyecto de jardín en casa hizo que tu salud mental, bienestar y felicidad sea ...

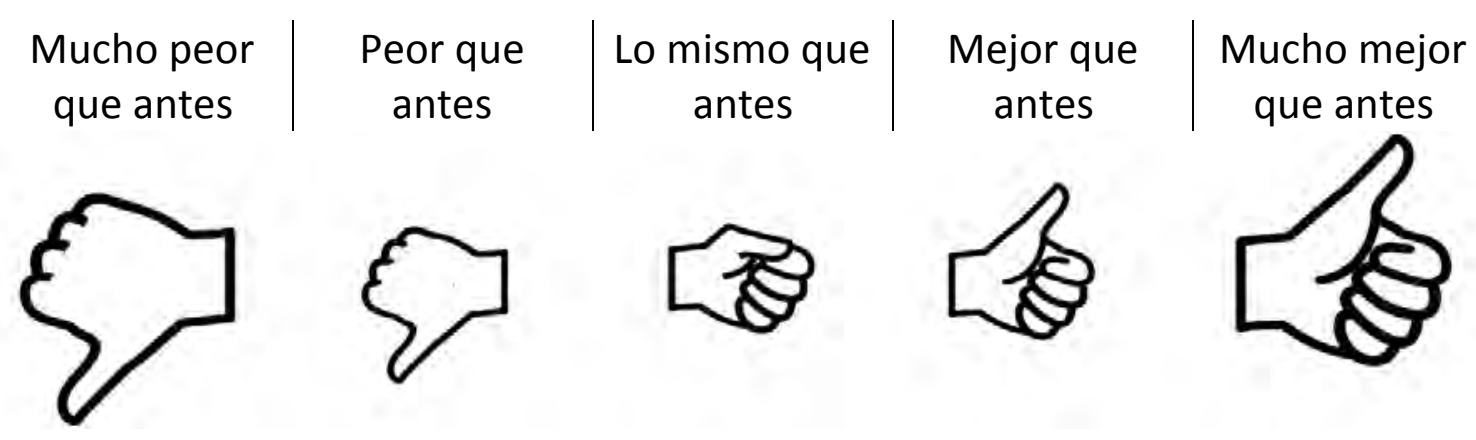

2 El proyecto de jardín en casa hizo que el acceso a los alimentos, comida...

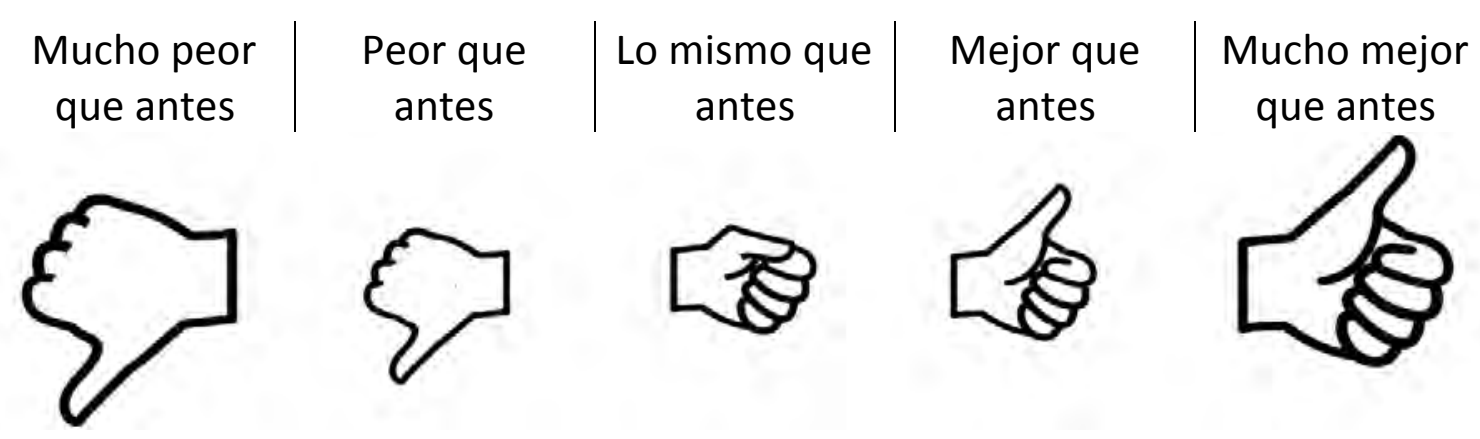

3 El proyecto de jardín en casa hizo que el medio ambiente en tu comunidad sea...

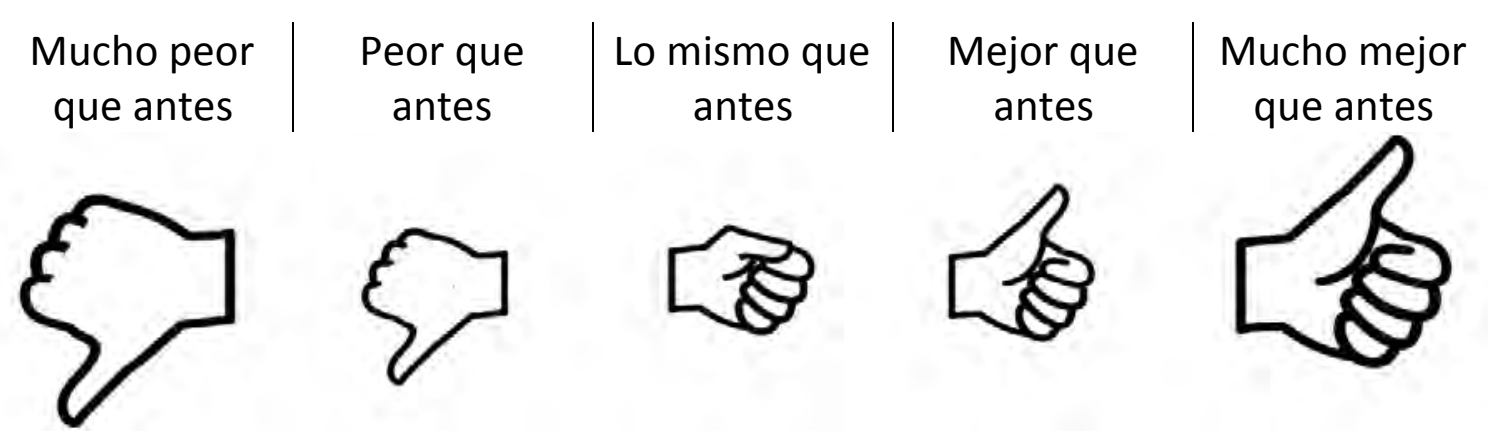


4 El proyecto de jardín en casa hizo que como tu comunidad se vea...

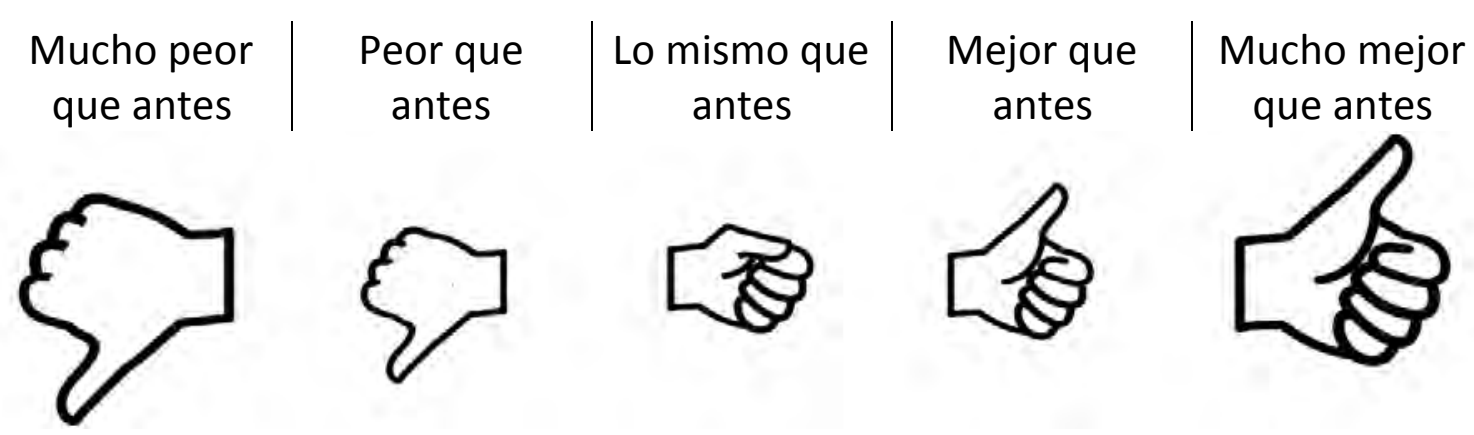

5 El proyecto de jardín en casa hizo que como tu calidad de vida sea...

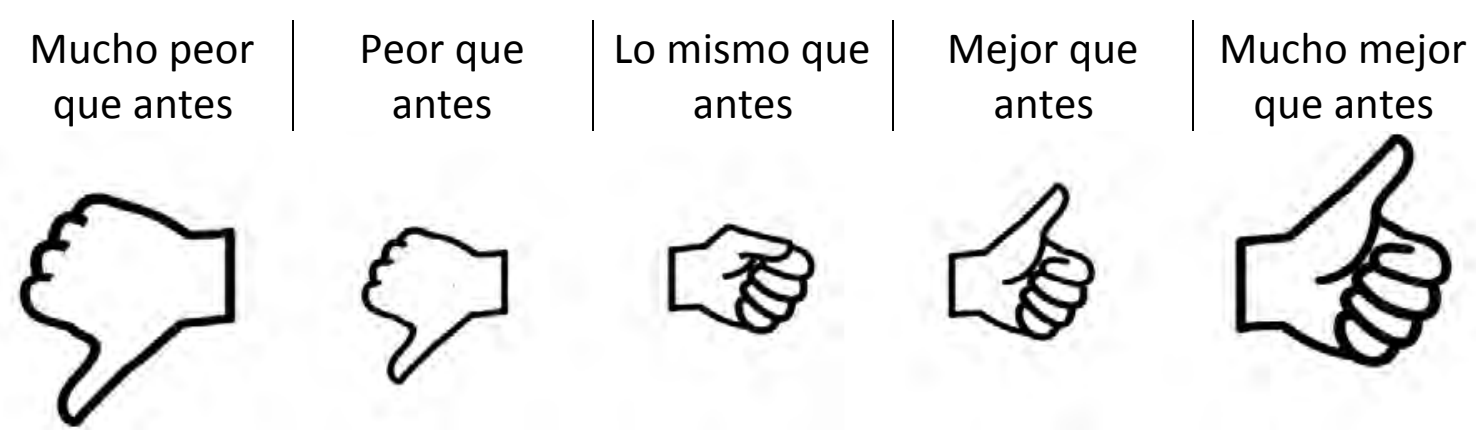

6 ¿Qué es lo que más te desagrada (lo que menos te gusta) de los jardines en casa?

7 ¿Qué es lo que más te agrada (lo que más te gusta) de los jardines en casa?

8 ¿Hay algo que quieras comentarnos o compartir sobre los jardines en casa? 


\begin{tabular}{|c|c|c|}
\hline $0-5$ & Preguntas adicionales \\
Evaluación (PIA) post-intervención & \\
\hline
\end{tabular}

\begin{tabular}{l|l|l}
$\square$ Hombre \\
$\square$ Mujer
\end{tabular} \mid Edad:___ ¿ ¿ ¿ $\quad$ ¿articipó en la construcción? $\square$ Sí $\square$ No

Marque con una X la respuesta que refleja mejor su opinión y responda las preguntas que corresponda

1 ¿Los proyectos han influenciado el tiempo que TU pasas afuera?

\begin{tabular}{|l|l|l|l|l|}
\hline $\begin{array}{l}\square \text { Paso mucho } \\
\text { menos tiempo } \\
\text { afuera que } \\
\text { antes }\end{array}$ & $\begin{array}{l}\square \text { Paso menos } \\
\text { tiempo afuera } \\
\text { que antes }\end{array}$ & $\begin{array}{l}\square \text { Paso el } \\
\text { mismo tiempo } \\
\text { afuera que } \\
\text { antes }\end{array}$ & $\begin{array}{l}\square \text { Paso más } \\
\text { tiempo afuera } \\
\text { que antes }\end{array}$ & $\begin{array}{l}\square \text { Paso mucho } \\
\text { más tiempo } \\
\text { afuera que } \\
\text { antes }\end{array}$ \\
\hline
\end{tabular}

2 ¿Los proyectos han influenciado el tiempo que TUS HIJOS pasan afuera?

\begin{tabular}{|l|l|l|l|l|}
\hline $\begin{array}{l}\square \text { Pasan mucho } \\
\text { menos tiempo } \\
\text { afuera que } \\
\text { antes }\end{array}$ & $\begin{array}{l}\square \text { Pasan menos } \\
\text { tiempo afuera } \\
\text { que antes }\end{array}$ & $\begin{array}{l}\square \text { Pasan el } \\
\text { mismo tiempo } \\
\text { afuera que } \\
\text { antes }\end{array}$ & $\begin{array}{l}\square \text { Pasan más } \\
\text { tiempo afuera } \\
\text { que antes }\end{array}$ & $\begin{array}{l}\square \text { Pasan mucho } \\
\text { más tiempo } \\
\text { afuera que } \\
\text { antes }\end{array}$ \\
\hline
\end{tabular}

3. ¿Cómo te sientes respecto a los cambios producidos por el proyecto?

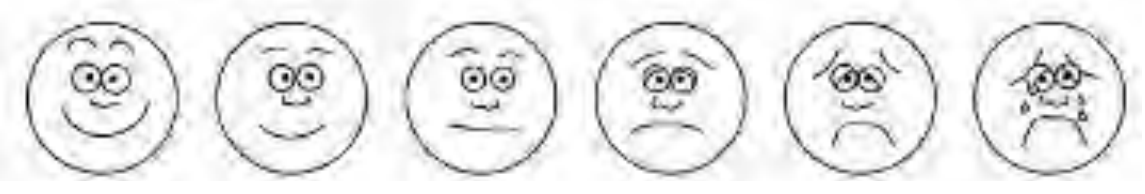

4 ¿Los proyectos han influenciado el tiempo que pasas haciendo ejercicios o deporte?

\begin{tabular}{|l|l|l|l|l|}
\hline $\begin{array}{l}\square \text { Paso mucho } \\
\text { menos tiempo } \\
\text { que antes }\end{array}$ & $\begin{array}{l}\square \text { Paso menos } \\
\text { tiempo que } \\
\text { antes }\end{array}$ & $\begin{array}{l}\square \text { Paso el } \\
\text { mismo tiempo } \\
\text { que antes }\end{array}$ & $\begin{array}{l}\square \text { Paso más } \\
\text { tiempo que } \\
\text { antes }\end{array}$ & $\begin{array}{l}\square \text { Paso mucho } \\
\text { más tiempo que } \\
\text { antes }\end{array}$ \\
\hline
\end{tabular}

5 ¿Los proyectos han influenciado el tiempo que pasas con tus vecinos?

\begin{tabular}{|l|l|l|l|l|}
\hline$\square$ Paso mucho & $\square$ Paso menos & $\square$ Paso el & $\square$ Paso más & $\square$ Paso mucho \\
menos tiempo & tiempo que & mismo tiempo & tiempo que \\
que antes & antes & que antes & antes & antes \\
\hline
\end{tabular}


6 ¿Los proyectos han influenciado en tus relaciones y colaboración con tus vecinos en Eliseo Collazos?

\begin{tabular}{|l|l|l|l|l|}
\hline$\square$ Las relaciones & $\square$ Las relaciones & $\square$ Las relaciones & $\square$ Las relaciones & $\square$ Las relaciones \\
han empeorado & han empeorado & son las mismas & han mejorado & han mejorado \\
mucho debido a & debido a los & debido a los & debido a los & mucho debido a \\
los proyectos & proyectos & proyectos & proyectos & los proyectos \\
\hline
\end{tabular}

7. ¿Cuál es el principal uso (propósito) de las plantas en tu jardín?

\begin{tabular}{|l|l|l|l|l|}
\hline $\begin{array}{l}\square \text { Comida, } \\
\text { alimento }\end{array}$ & $\square$ Medicina & $\square$ Decoración & $\square$ Para la venta & $\square$ Otros \\
\hline
\end{tabular}

Si es otro, explica cómo.

8 ¿Los proyectos han influenciado la seguridad en tu comunidad?

\begin{tabular}{|l|l|l|l|l|}
\hline $\begin{array}{l}\square \text { La seguridad } \\
\text { ha empeorado } \\
\text { mucho debido a } \\
\text { los proyectos }\end{array}$ & $\begin{array}{l}\square \text { La seguridad } \\
\text { ha empeorado } \\
\text { debido a los } \\
\text { proyectos }\end{array}$ & $\begin{array}{l}\square \text { La seguridad } \\
\text { es la misma }\end{array}$ & $\begin{array}{l}\square \text { La seguridad } \\
\text { ha mejorado } \\
\text { debido a los } \\
\text { proyectos }\end{array}$ & $\begin{array}{l}\square \text { La seguridad } \\
\text { ha mejorado } \\
\text { mucho debido a } \\
\text { los proyectos }\end{array}$ \\
\hline
\end{tabular}

9 ¿Los proyectos han influenciado tu situación?

\begin{tabular}{|c|c|c|c|c|}
\hline $\begin{array}{l}\text { Mi situación } \\
\text { económica ha } \\
\text { empeorado } \\
\text { mucho debido a } \\
\text { los proyectos }\end{array}$ & $\begin{array}{l}\square \text { Mi situación } \\
\text { económica ha } \\
\text { empeorado } \\
\text { debido a los } \\
\text { proyectos }\end{array}$ & $\begin{array}{l}\square \text { Mi situación } \\
\text { económica es la } \\
\text { misma }\end{array}$ & $\begin{array}{l}\square \text { Mi situación } \\
\text { económica ha } \\
\text { mejorado } \\
\text { debido a los } \\
\text { proyectos }\end{array}$ & $\begin{array}{l}\square \text { Mi situación } \\
\text { económica ha } \\
\text { mejorado } \\
\text { mucho debido a } \\
\text { los proyectos }\end{array}$ \\
\hline
\end{tabular}




\section{Research Instruments}

Appendix 2: Mental Health and Quality of Life Questionnaire with WHO Scoring Instructions 
Community Gardens and Health in Lima, Peru

Questionnaire Booklet

\author{
Joachim Voss, PhD \\ University of Washington \\ School of Nursing \\ Seattle, WA 98195
}


School of Nursing

University of Washington, Seattle

vossj@uw.edu

Version - March 14, 2013

Traducción al español por:

Francisca Salazar, RN, DNPc

Versión - March 2013

Consentimiento obtenido por (Consent obtained by):

Datos recolectados por (Data collected by):

Instrumento fue (instrument was):

Completado por participante (completed by participant)

Leído a participante (read to a participant)

Ambos (both)

Fecha en que se completa cuestionario: (date questionnaire was complete) 
Soles $500-1000$

Soles $1,000-1,500$

Soles $1,500-2,000$

Soles 2,000- 2,500

Soles 2,500+

11. Are you currently ill or do you have chronic illness? Yes No

12. If something is wrong illness/problem with your health, what do you think it is?

13.What is your height? $\mathrm{cm}$

14. What is your weight $\mathrm{kg}$

15. What is your waste circumference $\mathrm{cm}$

16. What is your blood pressure?

17. What is your blood sugar?

18. Do you drink alcohol? Yes No

19. How many drinks a day? $\quad 1 \quad \begin{array}{lllll}2 & 3 & 4 & >4\end{array}$

20. Do you smoke? Yes No

21. How many cigarettes a day? $5 \quad \begin{array}{lllll}10 & 15 & 20 & >20\end{array}$

22. Do you exercise?

Yes

No

23. How often do you exercise a week? $11 \quad 2 \quad 3 \quad 3 \quad>3$

24. How would you describe the condition of your mouth and teeth?
Poor
Fair
Good
Very Good

25. How often have you had pain in the teeth, mouth, or jaws?
Never
Hardly Ever
On Occasion Often Very Often 
1. What is your age

2. What is your gender

a. Male

b. Female

3. Please list all of the members of your household including their relationship to you (e.g husband, son, daughter), their gender and their age.

\begin{tabular}{|c|c|c|}
\hline Relationship to you & Gender & Age \\
\hline a._ & $\mathrm{M} / \mathrm{F}$ & \\
\hline b. & $\mathrm{M} / \mathrm{F}$ & \\
\hline c. & $\mathrm{M} / \mathrm{F}$ & \\
\hline d. & $\mathrm{M} / \mathrm{F}$ & \\
\hline e. & $\mathrm{M} / \mathrm{F}$ & \\
\hline f. & $\mathrm{M} / \mathrm{F}$ & \\
\hline
\end{tabular}

4. Where were you born?

5. What is your marital status?

Single

Married

Living as married
Separated

Divorced

Widowed

6. How long have you lived in Lomas de Zapallal?

a. Years

7. Where did you live before?

8. What was the main reason for you to move to Lomas de Zapallal?

9. What is your education? Circle the highest grade or year of school that you completed.

$\begin{array}{lllllllllllll}1 & 2 & 3 & 4 & 5 & 6 & 7 & 8 & 9 & 10 & 11 & 12 & 12+\end{array}$

10. What is your current monthly household income?

Soles $0-500$ 
Las siguientes afirmaciones intentan conocer sus pensamientos y sentimientos en diversas situaciones.

En cada una, indique hasta qué punto le describe rodeando el número más apropiado.

(The next statements are intended to understand your thoughts and feelings in diverse situations)

\section{LEA CADA AFIRMACIÓN ATENTAMENTE ANTES DE RESPONDER.}

(Please read every statement carefully before responding)

Conteste de la manera más honesta y precisa que pueda. Gracias.

(Answer each question honestly and as precise as you can. Thank you!)

Escala de respuesta. (Scale of answers)

Deberá decidir si las afirmaciones le describen a usted: (state if the following statements describe you)

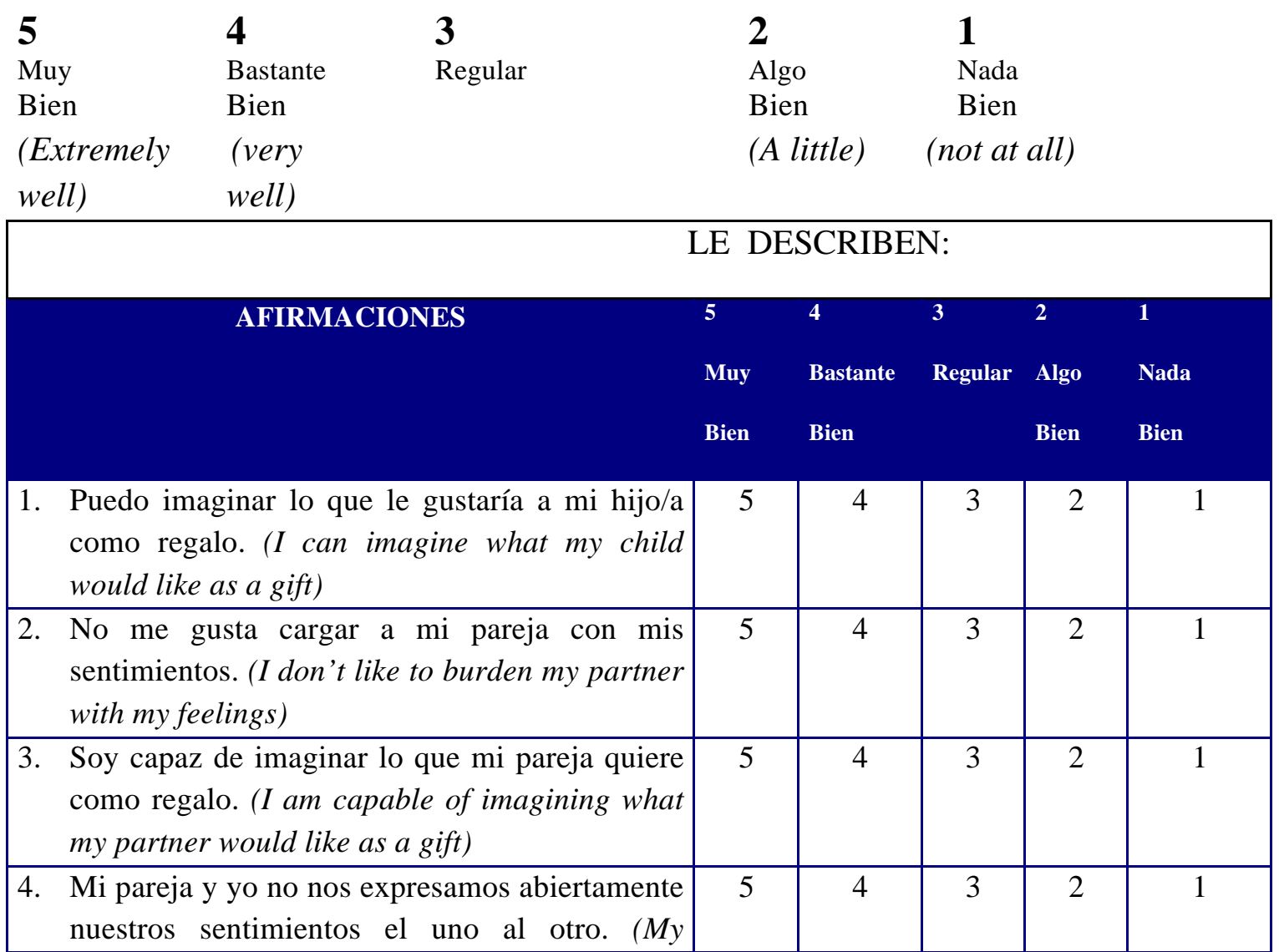




\begin{tabular}{|c|c|c|c|c|c|}
\hline $\begin{array}{l}\text { partner and I openly express our feelings to } \\
\text { each other) }\end{array}$ & & & & & \\
\hline $\begin{array}{l}\text { 5. Tengo dificultades para entender cómo se } \\
\text { siente mi hijo/a. (I have a hard time } \\
\text { understanding how my child feels) }\end{array}$ & 5 & 4 & 3 & 2 & 1 \\
\hline $\begin{array}{l}\text { 6. Se me hace difícil leer los sentimientos en la } \\
\text { cara de mi pareja. (I have a hard time reading } \\
\text { my partners feelings) }\end{array}$ & 5 & 4 & 3 & 2 & 1 \\
\hline $\begin{array}{l}\text { 7. Mi pareja dice que no soy sensible a sus } \\
\text { sentimientos. (My partner says I'm not sensitive } \\
\text { to their feelings) }\end{array}$ & 5 & 4 & 3 & 2 & 1 \\
\hline $\begin{array}{l}\text { 8. Mi hijo/a puede estar molesto durante varios } \\
\text { días antes de que yo me de cuenta de que algo } \\
\text { va mal. (My child can be upset for many days } \\
\text { before I realize something is wrong) }\end{array}$ & 5 & 4 & 3 & 2 & 1 \\
\hline $\begin{array}{l}\text { 9. Intento ver las cosas a través de los ojos de mi } \\
\text { pareja. (I try to see things from my partners } \\
\text { perspective) }\end{array}$ & 5 & 4 & 3 & 2 & 1 \\
\hline $\begin{array}{l}\text { 10. Me enfado mucho cuando mi pareja es tratado/a } \\
\text { injustamente. (It upsets me when my partner is } \\
\text { treated unfaily) }\end{array}$ & 5 & 4 & 3 & 2 & 1 \\
\hline $\begin{array}{l}\text { 11. Tengo problemas para adivinar lo que quiere mi } \\
\text { hijo/a. (I have problems guessing what my child } \\
\text { wants) }\end{array}$ & 5 & 4 & 3 & 2 & 1 \\
\hline $\begin{array}{l}\text { 12. Puedo adivinar correctamente lo que mi pareja } \\
\text { está sintiendo. (I can guess correctly what my } \\
\text { partner is feeling) }\end{array}$ & 5 & 4 & 3 & 2 & 1 \\
\hline $\begin{array}{l}\text { 13. Tengo problemas para entender a mi pareja. ( I } \\
\text { have problems understanding my partner) }\end{array}$ & 5 & 4 & 3 & 2 & 1 \\
\hline $\begin{array}{l}\text { 14. Soy rápido/a para darme cuenta de lo que le } \\
\text { gusta y disgusta a mi hijo/a. (I am quick to } \\
\text { notice what my child likes/does not like) }\end{array}$ & 5 & 4 & 3 & 2 & 1 \\
\hline $\begin{array}{l}\text { 15. Mi pareja me dice que no le entiendo. (My } \\
\text { partner tells me I don't understand him) }\end{array}$ & 5 & 4 & 3 & 2 & 1 \\
\hline $\begin{array}{l}\text { 16. Mi pareja y yo tenemos los mismos } \\
\text { sentimientos sobre las cosas. ( my parnert and I } \\
\text { have the same feelings about things) }\end{array}$ & 5 & 4 & 3 & 2 & 1 \\
\hline $\begin{array}{l}\text { 17. Pienso que es importante saber cómo se siente } \\
\text { mi hijo/a. (I think it's important to know how } \\
\text { my child is feeling) }\end{array}$ & 5 & 4 & 3 & 2 & 1 \\
\hline $\begin{array}{l}\text { 18. Me siento feliz cuando le pasa algo bueno a mi } \\
\text { pareja.(I a happy when something good } \\
\text { happens to my partner })\end{array}$ & 5 & 4 & 3 & 2 & 1 \\
\hline
\end{tabular}




\begin{tabular}{|c|c|c|c|c|c|}
\hline \multirow[b]{2}{*}{ AFIRMACIONES } & \multicolumn{4}{|c|}{ LE DESCRIBEN: } & \multirow[b]{2}{*}{$\begin{array}{l}1 \\
\text { Nada } \\
\text { Bien }\end{array}$} \\
\hline & $\begin{array}{l}5 \\
\text { Muy } \\
\text { Bien }\end{array}$ & $\begin{array}{l}4 \\
\text { Bastante } \\
\text { Bien }\end{array}$ & $\begin{array}{l}3 \\
\text { Regular }\end{array}$ & \begin{tabular}{l|l}
2 \\
Algo \\
Bien
\end{tabular} & \\
\hline $\begin{array}{l}\text { 19. Cuando mi hijo/a se porta mal, intento no } \\
\text { escuchar las excusas. (When my child behaves } \\
\text { badly, I try not to listen to excuses) }\end{array}$ & 5 & 4 & 3 & 2 & 1 \\
\hline $\begin{array}{l}\text { 20. Los niños deben ser vistos pero no oídos. } \\
\text { (Children should be seen not heard) }\end{array}$ & 5 & 4 & 3 & 2 & 1 \\
\hline $\begin{array}{l}\text { 21. Encuentro difícil expresar a mi pareja mis } \\
\text { sentimientos. (I find it hard to express my } \\
\text { feelings to my partner) }\end{array}$ & 5 & 4 & 3 & 2 & 1 \\
\hline $\begin{array}{l}\text { 22. Cuando veo una película me siento muy } \\
\text { "metido/a" en ella. (When I watch a movie, I } \\
\text { get lost in it) }\end{array}$ & 5 & 4 & 3 & 2 & 1 \\
\hline $\begin{array}{l}\text { 23. Me duele cuando veo que un niño está siendo } \\
\text { castigado. (It hurts me when I see a child that } \\
\text { is getting punished) }\end{array}$ & 5 & 4 & 3 & 2 & 1 \\
\hline $\begin{array}{l}\text { 24. Soy sensible a los pequeños cambios de } \\
\text { humor de mi hijo/a. ( I am sensitive to my } \\
\text { childs mood) }\end{array}$ & 5 & 4 & 3 & 2 & 1 \\
\hline $\begin{array}{l}\text { 25. Cuando mi hijo/a está molesto/a, es difícil } \\
\text { decir si está triste o sólo nervioso/a. (When my } \\
\text { child is in a bad mood it is hard to know } \\
\text { whether they are sad or nervous) }\end{array}$ & 5 & 4 & 3 & 2 & 1 \\
\hline $\begin{array}{l}\text { 26. No me gusta besar y abrazar a mi hijo/a en } \\
\text { público. (I don't like to kiss or hug in public) }\end{array}$ & 5 & 4 & 3 & 2 & 1 \\
\hline $\begin{array}{l}\text { 27. Me duele cuando el médico le pone una } \\
\text { inyección a mi hijo/a. (It hurts me when my } \\
\text { child gets an injection) }\end{array}$ & 5 & 4 & 3 & 2 & 1 \\
\hline $\begin{array}{l}\text { 28. Me gusta que mi hijo/a se guarde sus } \\
\text { sentimientos para sí mismo/a. (I like that my } \\
\text { child to keep their feelings to themselves) }\end{array}$ & 5 & 4 & 3 & 2 & 1 \\
\hline $\begin{array}{l}\text { 29. Cuando mi pareja se deprime, yo también me } \\
\text { siento mal. (When my partner is depressed, I } \\
\text { feel bad) }\end{array}$ & 5 & 4 & 3 & 2 & 1 \\
\hline $\begin{array}{l}\text { 30. Intento considerar los sentimientos de mi } \\
\text { pareja antes de hacer algo que le afecta. ( I try } \\
\text { to consider my partners feeling before I do } \\
\text { something that may affect them) }\end{array}$ & 5 & 4 & 3 & 2 & 1 \\
\hline
\end{tabular}




\begin{tabular}{|l|l|l|l|l|l|}
\hline $\begin{array}{l}\text { 31. Me siento alterado/a cuando veo sufrir a un } \\
\text { animal. (I get upset when I see an animal } \\
\text { suffering) }\end{array}$ & 5 & 4 & 3 & 2 & 1 \\
\hline $\begin{array}{l}\text { 32. Me resulta difícil estar de buen humor cuando } \\
\text { mi hijo/a está triste. (It's hard for me to be in } \\
\text { a good mood when my child is sad) }\end{array}$ & 5 & 4 & 3 & 2 & 1 \\
\hline $\begin{array}{l}\text { 33. Intento no prestar demasiada atención a cómo } \\
\text { se siente mi hijo/a. (I try not to pay too much } \\
\text { attention to how my child is feeling) }\end{array}$ & 5 & 4 & 3 & 2 & 1 \\
\hline $\begin{array}{l}\text { 34. Incluso cuando no estoy de acuerdo con mi } \\
\text { pareja, intento entender su punto de vista. } \\
\text { (Even when I am in disagreement with my } \\
\text { partner, I try to understand their point of } \\
\text { view) }\end{array}$ & 5 & 4 & 3 & 2 & 1 \\
\hline $\begin{array}{l}\text { 35. Cuando mi hijo/a está frustrado, siento algo de } \\
\text { su frustración. (When my child feels }\end{array}$ & 5 & 4 & 3 & 2 & 1 \\
frustrated, I feel some of their frustration) & & & & & \\
\hline $\begin{array}{l}\text { 36. Soy la última persona en saber cómo se siente } \\
\text { mi pareja. (I am the last person to know how } \\
\text { my partner feels) }\end{array}$ & 5 & 4 & 3 & 2 & 1 \\
\hline $\begin{array}{l}\text { 37. Me enfada que mi pareja llore. (I get angry } \\
\text { when my partner cries) }\end{array}$ & 5 & 4 & 3 & 2 & 1 \\
\hline $\begin{array}{l}\text { 38. Puedo decir cuándo mi pareja está temeroso/a } \\
\text { o nervioso/a. (I can tell when my partner is } \\
\text { scared or nervous) }\end{array}$ & 5 & 4 & 3 & 2 & 1 \\
\hline $\begin{array}{l}\text { 39. Mi pareja se queja de que no soy muy } \\
\text { compasivo/a. (My partner complains that I am } \\
\text { not compassionate) }\end{array}$ & 5 & 4 & 3 & 2 & 1 \\
\hline $\begin{array}{l}\text { 40. Cuando veo cosas tristes me echo a llorar. } \\
\text { (When I see sad things I cry) }\end{array}$ & 5 & 4 & 3 & 2 & 1 \\
\hline
\end{tabular}


Instructions

This questionnaire asks how you feel about your quality of life, health, or other areas of your life. Please answer all the questions. If you are unsure about which response to give to a question, please choose the one that appears most appropriate. This can often be your first response.

Please keep in mind your standards, hopes, pleasures and concerns. We ask that you think about your life in the last two weeks. For example, thinking about the last two weeks, a question might ask:

\begin{tabular}{|c|c|c|c|c|}
\hline \multicolumn{5}{|c|}{ (Please circle the number) } \\
\hline Not at all & A little & Moderately & Mostly & Completely \\
$\mathbf{1}$ & $\mathbf{2}$ & $\mathbf{3}$ & $\mathbf{4}$ & $\mathbf{5}$
\end{tabular}

Do you get the kind of support from others that you need?

You should circle the number that best fits how much support you got from others over the last two weeks. So you would circle the number 4 if you got a great deal of support from others.

\begin{tabular}{|c|c|c|c|c|}
\hline \multicolumn{5}{|c|}{ (Please circle the number) } \\
\hline Not at all & A little & Moderately & Mostly & Completely \\
$\mathbf{1}$ & $\mathbf{2}$ & $\mathbf{3}$ & (4) & $\mathbf{5}$
\end{tabular}

Do you get the kind of support

From others that you need?

You would circle number 1 if you did not get any of the support that you needed from others in the last two weeks.

support from others that

\begin{tabular}{|c|c|c|c|c|}
\hline \multicolumn{5}{|c|}{ (Please circle the number) } \\
\hline Not at all & A little & Moderately & Mostly & Completely \\
\hline (1) & 2 & 3 & 4 & 5 \\
\hline
\end{tabular}
you need? 
Please read each question, assess your feelings, and circle the number on the scale that gives the best answer for you for each question.

1. How would you rate your quality of life?

\begin{tabular}{|c|c|c|c|c|}
\hline \multicolumn{5}{|c|}{ (Please circle the number) } \\
\hline Very poor & Poor & $\begin{array}{c}\text { Neither poor } \\
\text { nor good }\end{array}$ & Good & Very good \\
1 & 2 & 3 & 4 & 5
\end{tabular}

\begin{tabular}{|c|c|c|c|c|}
\hline \multicolumn{5}{|c|}{ (Please circle the number) } \\
\hline $\begin{array}{c}\text { Very } \\
\text { dissatisfied }\end{array}$ & Dissatisfied & $\begin{array}{c}\text { Neither } \\
\text { satisfied nor } \\
\text { dissatisfied }\end{array}$ & Satisfied & $\begin{array}{c}\text { Very } \\
\text { satisfied }\end{array}$ \\
\hline
\end{tabular}

2. How satisfied are 1

2

3

4

5

The following questions ask about how much you have experienced certain things in the last two weeks.

\begin{tabular}{|c|c|c|c|c|}
\hline \multicolumn{5}{|c|}{ (Please circle the number) } \\
\hline Not at all & A little & A moderate & Very & An extreme \\
& & amount & much & amount \\
$\mathbf{1}$ & $\mathbf{2}$ & $\mathbf{3}$ & $\mathbf{4}$ & $\mathbf{5}$
\end{tabular}

3. To what extent do you feel that physical pain prevents you from doing what you need to do?

4. How much do you

1 2 3

4 5 need any medical treatment to function in your daily life?

5. How much do you enjoy life?

$\begin{array}{lll}1 & 2 & 3\end{array}$

4

5

(Please circle the number)

\begin{tabular}{|c|c|c|c|c|}
\hline Not at all & A little & $\begin{array}{c}\text { A Moderate } \\
\text { amount }\end{array}$ & $\begin{array}{c}\text { Very } \\
\text { much }\end{array}$ & $\begin{array}{c}\text { An extreme } \\
\text { amount }\end{array}$
\end{tabular}
6. To what extent do
1
2
3
4
5 you feel your life to be meaningful? 
(Please circle the number)

\begin{tabular}{|l|l|c|c|c|} 
Not at all & Slightly & $\begin{array}{c}\text { A Moderate } \\
\text { amount }\end{array}$ & $\begin{array}{c}\text { Very } \\
\text { much }\end{array}$ & Extremely
\end{tabular}

7. How well are you

1

2

3

5

able to concentrate?

8. How safe do you 1

12

3

4

5

feel in your daily life?

9. How healthy is your

physical environment?

1

2

3

4

5

The following questions ask about how completely you experience or were able to do certain things in the last two weeks.

\begin{tabular}{|c|c|c|c|c|}
\hline \multicolumn{5}{|c|}{ (Please circle the number) } \\
\hline Not at all & A little & $\begin{array}{c}\text { A moderate } \\
\text { amount }\end{array}$ & $\begin{array}{c}\text { Very } \\
\text { much }\end{array}$ & $\begin{array}{c}\text { An extreme } \\
\text { amount }\end{array}$
\end{tabular}

10. Do you have

enough energy for

everyday life?

11. Are you able to

1

2

3

4

5

accept your bodily

1

2

3

4

5

appearance?

12. Have you enough

1

2

3

4

5 money to meet your needs?

\begin{tabular}{|c|c|c|c|c|}
\hline \multicolumn{5}{|c|}{ (Please circle the number) } \\
\hline Not at all & A little & $\begin{array}{c}\text { A moderate } \\
\text { amount }\end{array}$ & $\begin{array}{c}\text { Very } \\
\text { much }\end{array}$ & $\begin{array}{c}\text { An extreme } \\
\text { amount }\end{array}$
\end{tabular}

13. How available to 1 2 3

4

5 you is the information that you need in your day-to-day life?

14. To what extent do 1 2 3

you have the opportunity for leisure activities? 


\begin{tabular}{|c|c|c|c|c|}
\hline \multicolumn{5}{|c|}{ (Please circle the number) } \\
\hline Very poor & Poor & $\begin{array}{l}\text { Neither poor } \\
\text { nor well }\end{array}$ & Well & Very well \\
\hline
\end{tabular}

15. How well are you

1

2

3

4

5 able to get around?

The following questions ask you to say how good or satisfied you have felt about various aspects of your life over the last two weeks.

\begin{tabular}{|c|c|c|c|c|}
\hline \multicolumn{5}{|c|}{ (Please circle the number) } \\
\hline $\begin{array}{c}\text { Very } \\
\text { dissatisfied }\end{array}$ & Dissatisfied & $\begin{array}{c}\text { Neither } \\
\text { satisfied nor } \\
\text { dissatisfied }\end{array}$ & Satisfied & $\begin{array}{c}\text { Very } \\
\text { satisfied }\end{array}$ \\
\hline
\end{tabular}

16. How satisfied are

1

2

3

4

5

you with your sleep?

17. How satisfied are

1

2

3

4

5

you with your

ability to perform

your daily living

activities?

18. How satisfied are

1

2

3

4

5

you with your

capacity for work?

\begin{tabular}{|c|c|c|c|c|}
\hline \multicolumn{5}{|c|}{ (Please circle the number) } \\
\hline $\begin{array}{c}\text { Very } \\
\text { dissatisfied }\end{array}$ & Dissatisfied & $\begin{array}{c}\text { Neither } \\
\text { satisfied nor } \\
\text { dissatisfied }\end{array}$ & Satisfied & $\begin{array}{c}\text { Very } \\
\text { satisfied }\end{array}$ \\
\hline
\end{tabular}

19. How satisfied are

1

2

3

4

5

you with your

abilities?

20. How satisfied are

1

2

3

4

5

you with your

personal

relationships?

21. How satisfied are

1

2

3

4

5 you with your sex

life? 


\begin{tabular}{|c|c|c|c|c|}
\hline \multicolumn{5}{|c|}{ (Please circle the number) } \\
\hline $\begin{array}{c}\text { Very } \\
\text { dissatisfied }\end{array}$ & Dissatisfied & $\begin{array}{c}\text { Neither } \\
\text { satisfied nor } \\
\text { dissatisfied }\end{array}$ & Satisfied & $\begin{array}{c}\text { Very } \\
\text { satisfied }\end{array}$ \\
\hline
\end{tabular}

22. How satisfied are

1

2

3

4

5

you with the

support you get

from your friends?

23. How satisfied are

1

2

3

4

5

you with the

conditions of your

living place?

24. How satisfied are

1

2

3

4

5

you with your

access to health

services?

25. How satisfied are

1

2

3

4

5 you with your

mode of

transportation?

The following question refers to how often you have felt or experienced certain things in the last two weeks.

\begin{tabular}{|c|c|c|c|c|}
\hline \multicolumn{4}{|c|}{ (Please circle the number) } \\
\hline Never & Seldom & Quite often & $\begin{array}{c}\text { Very } \\
\text { often }\end{array}$ & Always \\
\hline
\end{tabular}

26. How often do you

1

2

3

4

5

have negative feelings,

such as low mood, despair,

anxiety, depression?

Did someone help you to fill out this form?

Yes

No

How long did it take you to fill out this form? 
Las preguntas en esta escala hacen referencia a sus sentimientos y pensamientos durante el último mes. En cada caso, por favor indique con una " $X$ " cómo usted se ha sentido o ha pensado en cada situación (The questions on this scale refer to your feelings and thoughs during the last month. In each case, please indicate with an " $X$ " how you have feels or what you have thought or each situation.)

Las preguntas en esta escala hacen referencia a sus sentimientos y pensamientos durante el último mes. En cada caso, por favor indique con una " $\mathrm{X}$ " cómo usted se ha sentido o ha pensado en cada situación (The questions on this scale refer to your feelings and thoughs during the last month. In each case, please indicate with an " $X$ " how you have feels or what you have thought or each situation.)

\begin{tabular}{|c|c|c|c|c|c|c|}
\hline & & $\begin{array}{c}\text { Nunca } \\
\text { (Never) }\end{array}$ & $\begin{array}{l}\text { Casi } \\
\text { nunca } \\
\text { (Almost } \\
\text { never) }\end{array}$ & $\begin{array}{c}\text { De vez en } \\
\text { cuando } \\
\text { (Sometimes) }\end{array}$ & $\begin{array}{c}\text { A } \\
\text { Menudo } \\
\text { (Often) }\end{array}$ & $\begin{array}{c}\text { Muy a } \\
\text { menudo } \\
\text { (Very } \\
\text { often) }\end{array}$ \\
\hline PPS1 & $\begin{array}{l}\text { En el último mes, ¿con qué } \\
\text { frecuencia ha estado afectado } \\
\text { por algo que ha ocurrido } \\
\text { inesperadamente? (In the last } \\
\text { month, how frequently have you } \\
\text { been affected with something } \\
\text { that happened unexpectedly?) }\end{array}$ & 0 & 1 & 2 & 3 & 4 \\
\hline PSS2 & $\begin{array}{l}\text { En el último mes, ¿con qué } \\
\text { frecuencia se ha sentido } \\
\text { incapaz de controlar las cosas } \\
\text { importantes en su vida? (In the } \\
\text { last month, how often have you } \\
\text { felt unable to control the } \\
\text { important things in your life?) }\end{array}$ & 0 & 1 & 2 & 3 & 4 \\
\hline PSS3 & $\begin{array}{l}\text { En el último mes, ¿con qué } \\
\text { frecuencia se ha sentido } \\
\text { nervioso o estresado? (In the } \\
\text { last month, how frequently have } \\
\text { you felt nervous or stressed?) }\end{array}$ & 0 & 1 & 2 & 3 & 4 \\
\hline PSS4 & $\begin{array}{l}\text { En el último mes, ¿con qué } \\
\text { frecuencia ha manejado } \\
\text { con éxito los pequeños } \\
\text { problemas irritantes de la vida? } \\
\text { (In the last month, how } \\
\text { frequently have you successfully } \\
\text { managed the irritating problems } \\
\text { of life?) }\end{array}$ & 0 & 1 & 2 & 3 & 4 \\
\hline PSS5 & $\begin{array}{l}\text { En el último mes, ¿con qué } \\
\text { frecuencia ha sentido que } \\
\text { ha afrontado efectivamente los } \\
\text { cambios importantes } \\
\text { que han estado ocurriendo en su }\end{array}$ & 0 & 1 & 2 & 3 & 4 \\
\hline
\end{tabular}




\begin{tabular}{|c|c|c|c|c|c|c|}
\hline & $\begin{array}{l}\text { vida? (In the last month, how } \\
\text { frequently have you effectively } \\
\text { faced important changes } \\
\text { occurring in your life?) }\end{array}$ & & & & & \\
\hline PSS6 & $\begin{array}{l}\text { En el último mes, ¿con qué } \\
\text { frecuencia ha estado } \\
\text { seguro sobre su capacidad para } \\
\text { manejar sus problemas } \\
\text { personales? (In the last month, } \\
\text { how frequently have you been } \\
\text { sure about the capability of } \\
\text { managing you personal } \\
\text { problems?) }\end{array}$ & 0 & 1 & 2 & 3 & 4 \\
\hline PSS7 & $\begin{array}{l}\text { En el último mes, ¿con qué } \\
\text { frecuencia ha sentido que } \\
\text { las cosas le van bien? (In the } \\
\text { last month, how frequently have } \\
\text { you felt that things are going } \\
\text { well?) }\end{array}$ & 0 & 1 & 2 & 3 & 4 \\
\hline PSS8 & $\begin{array}{l}\text { En el último mes, ¿con qué } \\
\text { frecuencia ha sentido que } \\
\text { no podía afrontar todas las cosas } \\
\text { que tenía que hacer? (In the last } \\
\text { month, how frequently have you } \\
\text { felt unable to face the things } \\
\text { you needed to do?) }\end{array}$ & 0 & 1 & 2 & 3 & 4 \\
\hline PSS9 & $\begin{array}{l}\text { En el último mes, ¿con qué } \\
\text { frecuencia ha podido } \\
\text { controlar las dificultades de su } \\
\text { vida? (In the last month, how } \\
\text { frequently have you been able to } \\
\text { control difficulties in your life?) }\end{array}$ & 0 & 1 & 2 & 3 & 4 \\
\hline PSS10 & $\begin{array}{l}\text { En el último mes, ¿con qué } \\
\text { frecuencia se ha sentido } \\
\text { al control de todo? (In the last } \\
\text { month, how frequently have you } \\
\text { felt in control of everything?) }\end{array}$ & 0 & 1 & 2 & 3 & 4 \\
\hline PSS11 & $\begin{array}{l}\text { En el último mes, ¿con qué } \\
\text { frecuencia ha estado } \\
\text { enfadado porque las cosas que } \\
\text { le han ocurrido estaban } \\
\text { fuera de su control? (In the last } \\
\text { month, how frequently have you } \\
\text { gotten upset because things that } \\
\text { have happened to you are out of } \\
\text { your control?) }\end{array}$ & 0 & 1 & 2 & 3 & 4 \\
\hline
\end{tabular}




\begin{tabular}{|l|l|l|l|l|l|l|}
\hline PSS12 & $\begin{array}{l}\text { En el último mes, ¿con qué } \\
\text { frecuencia ha pensado } \\
\text { sobre las cosas que le quedan } \\
\text { por lograr? (In the last month, } \\
\text { how often have you thought of } \\
\text { the things you still have to } \\
\text { accomplish?) }\end{array}$ & 0 & 1 & 2 & 3 \\
\hline PSS13 & $\begin{array}{l}\text { En el último mes, ¿con qué } \\
\text { frecuencia ha podido } \\
\text { controlar la forma de pasar el } \\
\text { tiempo? (In the last month, how } \\
\text { frequently have you been able to } \\
\text { control the way you spend your } \\
\text { time?) }\end{array}$ & 0 & 1 & 2 & 3 & 4 \\
\hline PSS14 & $\begin{array}{l}\text { En el último mes, ¿con qué } \\
\text { frecuencia ha sentido que } \\
\text { las dificultades se acumulan } \\
\text { tanto que no puede } \\
\text { superarlas? (In the last month, } \\
\text { how frequently have you felt } \\
\text { difficulties accumulating so } \\
\text { much that you can't } \text { overcome } \\
\text { them?) }\end{array}$ & 0 & 1 & 2 & 3 & 4 \\
\hline
\end{tabular}

A continuación encontrará una lista de eventos que puedan ocurrir en su vida. Haga una marca en el sí o el NO para indicar si ese evento le ha ocurrido a usted durante el pasado mes. (In continuation, you will find a list of events that can happen in your life. Mark "yes" or "no" to indicate if this event has happened to you in the last month.)

\begin{tabular}{|c|c|c|c|}
\hline 1. & $\begin{array}{l}\text { ¿Fue agredido(a) o herido(a) de gravedad por otra persona? (Were } \\
\text { you severely assaulted or hurt by another person?) }\end{array}$ & ${ }_{\text {(yes) }}^{\text {sí }}$ & nO \\
\hline 2. & ¿Fue hospitalizado(a)? (Hospatalized?) & _ sí & $\ldots$ \\
\hline 3. & $\begin{array}{l}\text { ¿Algún miembro de su familia tuvo alguna enfermedad seria, fue } \\
\text { herido(a) o agredido(a)? ( Has a member of your family had a serious } \\
\text { illness, was hurt or assaulted?) }\end{array}$ & _ sí & _NO \\
\hline 4. & $\begin{array}{l}\text { ¿Murió su pareja, esposo(a), alguno de sus padres o hijos(as)? (Death } \\
\text { of your partner, spouse, one of your parents, or children?) }\end{array}$ & _ sí & NO \\
\hline
\end{tabular}




\begin{tabular}{|c|c|c|}
\hline 5. ¿Murió un familiar o amigo(a) cercano(a)? (Death of a close friend?) & ___ sí & NO \\
\hline $\begin{array}{l}\text { 6. ¿Se separó de su pareja/esposo(a) por dificultades? (Separated from } \\
\text { your partner or spouse because of difficulties?) }\end{array}$ & _ـ_ sí & _no \\
\hline 7. ¿Rompió una relación estable? (Ended a stable relationship?) & Sí & NO \\
\hline $\begin{array}{l}\text { 8. ¿Tuvo un problema serio con un familiar, amigo(a) cercano o algún(a) } \\
\text { vecino(a)? (Did you have a serious problem with a family member, } \\
\text { close friend, or neighbor?) }\end{array}$ & sí & NO \\
\hline $\begin{array}{l}\text { 9. ¿Tuvo problemas económicos serios? (Did you have serious economic } \\
\text { problems?) }\end{array}$ & __ sí & NO \\
\hline 10. ¿Perdió su trabajo? (Lost your job?) & _ sí & NO \\
\hline 11. ¿Estuvo sin lugar donde vivir? (Been without a place to live?) & sí & NO \\
\hline $\begin{array}{l}\text { 12. ¿Estuvo sin comer por no tener dinero? (Been without food because of } \\
\text { lack of maney?) }\end{array}$ & _ sí & NO \\
\hline $\begin{array}{l}\text { 13. ¿Se le perdió o le robaron alguna cosa de valor? (Have you lost or had } \\
\text { something of value stolen from you?) }\end{array}$ & sí & NO \\
\hline $\begin{array}{l}\text { 14. ¿Tuvo problemas con la policía? (Did you have problems with the } \\
\text { police?) }\end{array}$ & - Sí & - NO \\
\hline 15. ¿Estuvo desempleado(a)? (Were you unemployed?) & _ sí & NO \\
\hline 16. ¿'Fue abusado(a) sexualmente? (Were you abused sexualy?) & _ sí & NO \\
\hline 17. ¿Fue abusado(a) físicamente? (Were you abused physically?) & _ sí & NO \\
\hline 18. ¿Abusó de drogas o alcohol? (Abused drugs or alcohol?) & _ sí & NO \\
\hline $\begin{array}{l}\text { 19. ¿Fue rechazado(a) por otras personas por tener VIH? (Rejected by } \\
\text { other for having HIV?) }\end{array}$ & _ sí & NO \\
\hline $\begin{array}{l}\text { 20. ¿Rechazaron a miembros de su familia por usted tener VIH? (Rejected } \\
\text { member of your family because you have HIV?) }\end{array}$ & _ sí & nO \\
\hline
\end{tabular}

Por favor circule el numero que mejor indique/refleje su situación en estos momentos (Please circle the number that best indicates/reflects your situation at this time 
1. ¿Se siente usted valorado(a) por la sociedad? (Do you feel

No, no mucho

Sí, mucho valued by society?)

(No not much)

$\begin{array}{lllll}1 & 2 & 3 & 4 & \text { (Yes, Very }\end{array}$ much)

2. Sí usted se fuese a morir mañana, ¿estaría satisfecho(a) con lo que ha significado su vida? (If you were to die tomorrow, would you be satisfied with your life?)

No, no mucho $11 \quad 2 \quad 3 \quad 4 \quad$ Sí, mucho

3. ¿Alguna vez ha recogido la basura de otra persona en un lugar público? (Have you aever picked up other peoples garbage in a public place?)

No, no mucho $\begin{array}{llllll}1 & 2 & 3 & 4 & \text { Sí, mucho }\end{array}$

4. Algunos dicen que ayudar a otros te ayuda a ti a largo plazo. ¿Está de acuerdo? (Some say that helping other, helps you in the long run. Do you agree?)

No, no mucho $\quad 1 \quad 2 \quad 3 \quad 4 \quad$ Sí, mucho

5. ¿Usted ayuda en algún grupo local como voluntario(a)? (Do you help a local group as a volunteer?)

No, no mucho $\quad 1 \quad 2 \quad 3 \quad 3 \quad 4$ Sí, mucho

6. ¿Se siente usted seguro(a) al caminar en su calle en la noche? (Do you feel safe walking in your street at night?)

No, no mucho $11 \quad 2 \quad 3 \quad 4 \quad$ Sí, mucho

7. ¿Está usted de acuerdo en que se puede confiar en la mayoría de la gente? (Do you agree that you can trust the

No, no mucho $\begin{array}{llllll}1 & 2 & 3 & 4 & \text { Sí, mucho }\end{array}$ majority of people?)

8. ¿Sí a alguien se le daña el carro frente a su casa, ¿usted lo invitaría a usar el teléfono de su casa? (If someone's care breaks down in front of your home, would you invite them No, no mucho $\quad 1 \quad 2 \quad 3 \quad 3 \quad 4$ Sí, mucho inside to use the house phone?)

9. ¿Puede conseguir ayuda de amigos cuando usted la necesita? (Can you get help from friends when you need it?)

No, no mucho $\begin{array}{llllll}1 & 2 & 3 & 4 & \text { Sí, mucho }\end{array}$

10. ¿Su área tiene reputación de ser un lugar seguro? (Does your area have a reputation of being safe?)

No, no mucho $\quad 1 \quad 2 \quad 3 \quad 3 \quad 4$ Sí, mucho

11. ¿Si usted estuviese cuidando a un niño y necesitara salir un momento, ¿le pediría ayuda a su vecino? (If you were taking care of a child and had to leave a moment, would you ask No, no mucho $\quad 1 \quad 2 \quad 3 \quad 3 \quad 4$ Sí, mucho your neighbor for help?) 
12. ¿Ha visitado a algún vecino en la última semana? (Have you visited a neighbor in the last month?)

13. ¿Ha visitado algún evento local de la comunidad en los últimos 6 meses (ej., iglesia, concierto de la escuela, venta de artesanías)? (Have you attended a local community No, no mucho $1 \begin{array}{lllll}\text { Sí, mucho(porlo } & 2 & 3 & 4 & \text { menos } 3 \text { meses) }\end{array}$ event in the last 6 month? (ex. church, school concert, art sale))

14. ¿Es usted miembro(a) activo(a) de alguna organización o club local (ej. deportes, artesanías, social)? (Are you an active member of a local organization (ex. sports, arts, No, no mucho $\quad 1 \quad 2 \quad 2 \quad 3 \quad 4 \quad$ Sí, muy activo/a social))

15. Cuando está en su vecindario, ¿se siente cómo en su casa? (When in your neighborhood, do you feel at home?)

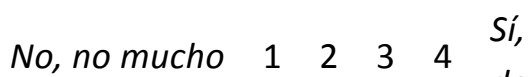
definitivamente

16. En la pasada semana, ¿cuántas conversaciones tuvo con sus amistades por teléfono? (In the last week, how many telephone conversations have you had with friends?) Ninguna $1 \begin{array}{llllll} & 2 & 3 & 4 & \begin{array}{l}\text { Muchos (por lo } \\ \text { menos 6) }\end{array}\end{array}$

17. ¿Con cuántas personas habló ayer? (How many people did you spreak with yesterday?)

Nadie $\begin{array}{llll}1 & 2 & 3 & 4\end{array}$ Muchos (por lo menos 10)

18. Durante el fin de semana, ¿almorzó/cenó con otras personas fuera de su hogar? (During the weekend, did you eat breakfast/dinner with people outside your home?)

19. ¿Sale de su comunidad para visitar a su familia? (Do you leave you neighborhood to visit family?)

No, no mucho $11 \quad 2 \quad 3 \quad 4 \quad$ Sí, casi siempre

20. Cuando sale de compras en su área local, ¿̇suele encontrarse con amigos(as) y conocidos(as)? (When your locally shopping, do you usually see friends and No, no mucho $11 \quad 2 \quad 3 \quad 4 \quad$ Sí, casi siempre acquaintances?

21. Si necesitara información para tomar una decisión sobre su vida, ¿sabe dónde puede encontrar esa información? (If you need information to make a decision in your life, do you No, no mucho $\quad 1 \quad 2 \quad 2 \quad 3 \quad 4 \quad \begin{aligned} & \text { Sí, } \\ & \text { definitivamente }\end{aligned}$ know where to find it?) 
22. En los pasados 6 meses, cile ha hecho algún favor a un(a) vecino(a) enfermo(a)? (In the last 6 months, have you done a favor for a neighbor or someone ill?)
No, no muchas veces)
$\begin{array}{lllll}1 & 2 & 3 & 4 & \text { frecuentemente }\end{array}$ (al menos 5)

23. ¿Está en algún comité administrativo u organización de algún grupo local u organización? (Are you in an administrative committee or group organization or No, no mucho $1 \begin{array}{llllll}\text { Sí, varias (al } & 2 & 3 & 4 & \text { menos } 3 \text { ) }\end{array}$ organization?)

24. En los pasados 3 años, ¿̇se ha unido a alguna acción comunitaria local para bregar con una emergencia? (In the last 3 years, have you joined a local community action to helpwith an emergency?)

\begin{tabular}{|c|c|c|c|c|c|}
\hline & & & & & Sí, \\
\hline $\begin{array}{r}\text { veces) } \\
\text { ver muchas }\end{array}$ & 1 & 2 & 3 & 4 & $\begin{array}{l}\text { frecuentemente } \\
\text { (al menos 5) }\end{array}$ \\
\hline
\end{tabular}

25. En los pasados 3 años, ¿ha sido parte de un proyecto comunitario local? (In the last 3 years, have you been part No, no mucho $\quad 1 \quad 2 \quad 3 \quad 3 \quad 4$ Sí, mucho of a local community project?)

26. ¿Alguna vez ha sido parte de un proyecto para organizar un nuevo servicio en su zona (ej. grupo para jóvenes, cuido de niños, recreación para impedidos)? (Have you ever been a part of a project to organize a new service in your No, no mucho $1 \begin{array}{llllll}\text { Sí, varios (a } \\ \text { menos 3) }\end{array}$ neighborhood (youth group, daycare, programs for diabled?)

27. Si usted estuviese en desacuerdo con lo que los demás decidieron, ¿se siente libre para decirlo? (If you didn't agree with what everyone else was saying, would you feel free to No, no mucho $\begin{array}{lllllll} & 2 & 3 & 4 & \begin{array}{l}\text { Sí, } \\ \text { definitivamente }\end{array}\end{array}$ speak?)

28. Si usted tiene alguna disputa con sus vecinos (ej. sobre música o animales) ¿estaría dispuesto(a) a buscar mediación? (if you had a dispute with a neighbor (ex. over No, no mucho $\quad \begin{array}{llllll}1 & 2 & 3 & 4 & \begin{array}{l}\text { Sí, } \\ \text { definitivamente }\end{array}\end{array}$ music or animals), would you look for mediation?)

29. ¿Piensa que la diversidad produce una mejor vida en su área? (Do you think the diversity produces a better life in your area?)

30. Disfruta usted de vivir entre personas con diferentes estilos de vida? (Do you enjoy living with people that have different lifestyles?) 
31. Si una persona diferente o extraña se muda a su calle, ¿serían aceptados(as) por sus vecinos? (If a different or strange person moves onto you street, would your neighbors accept them?)

Sí, definitivamente 


\section{WHOQOL-BREF}

\section{June 1997}

\section{U.S. Version}

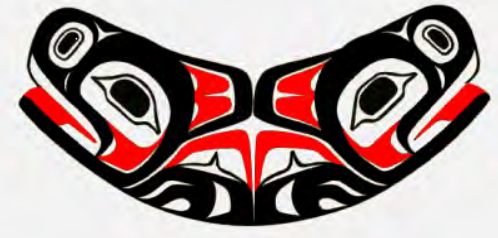

University of Washington

Seattle, Washington

United States of America

Emblem...Soul Catcher: a Northwest Coast Indian symbol of physical and mental well-being. Artist: Marvin Oliver 


\section{WHOQOL-BREF}

\section{About You}

Before you begin we would like to ask you to answer a few general questions about yourself by circling the correct answer or by filling in the space provided.

1. What is your gender

2. What is your date of birth?

3. What is the highest education you received?
Male

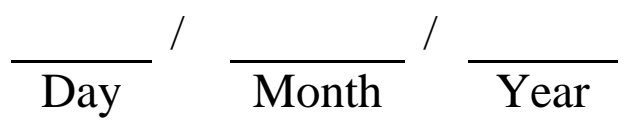

None at all

Elementary School

High School

College

4. What is your marital status?

Single

Married

Living as Married

Yes

No

illness/problem
Separated

Divorced

Widowed

5. Are you currently ill?

6. If something is wrong with your health, what do you think it is? 


\section{Instructions}

This questionnaire asks how you feel about your quality of life, health, or other areas of your life. Please answer all the questions. If you are unsure about which response to give to a question, please choose the one that appears most appropriate. This can often be your first response.

Please keep in mind your standards, hopes, pleasures and concerns. We ask that you think about your life in the last two weeks. For example, thinking about the last two weeks, a question might ask:

For office
use

Do you get the kind of support from others that you need?

\begin{tabular}{|l|l|l|l|l|}
\hline \multicolumn{5}{|c|}{ (Please circle the number) } \\
\hline Not at all & A little & Moderately & Mostly & Completely \\
\hline
\end{tabular}

1
3
5

You should circle the number that best fits how much support you got from others over the last two weeks. So you would circle the number 4 if you got a great deal of support from others. o

\section{For office use}

\begin{tabular}{|l|l|l|l|l|}
\hline \multicolumn{5}{|c|}{ (Please circle the number) } \\
\hline Not at all & A little & Moderately & Mostly & Completely \\
\hline
\end{tabular}

Do you get the kind of 1
2
3 you need?

You would circle number 1 if you did not get any of the support that you needed from others in the last two weeks. o

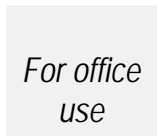

\begin{tabular}{|c|c|c|c|c|}
\hline \multicolumn{5}{|c|}{ (Please circle the number) } \\
\hline Not at all & A little & Moderately & Mostly & Completely \\
\hline
\end{tabular}

(1)
2 (1)
3 support from others that you need?

Do you get the kind of 
Please read each question, assess your feelings, and circle the number on the scale that gives the best answer for you for each question.

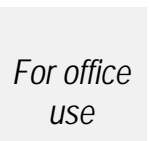

G1 / G1.1 1

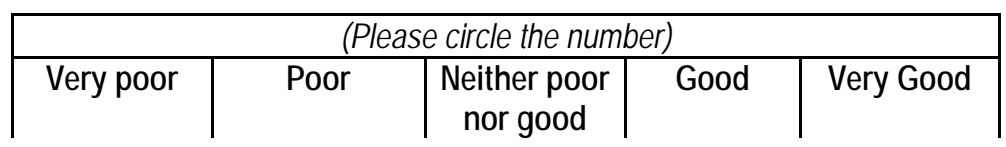

1
2
3
5 rate your quality of life?

For office use

G4 / G2.3 2.

\begin{tabular}{|c|c|c|c|c|}
\hline \multicolumn{5}{|c|}{ (Please circle the number) } \\
\hline $\begin{array}{c}\text { Very } \\
\text { dissatisfied }\end{array}$ & Dissatisfied & $\begin{array}{c}\text { Neither } \\
\text { satisfied nor } \\
\text { dissatisfied }\end{array}$ & Satisfied & Very satisfied \\
\hline
\end{tabular}

1

2

3

4

5 you with your health?

The following questions ask about how much you have experienced certain things in the last two weeks.

For office use

F1.4 / F1.2.5

3. To what extent do you feel that physical pain prevents you from doing what you need to do?

F11.3 / 4. How much do you 1

2

3

4

need any medical

treatment to

function in your daily life?

\section{F13.1.4}

\begin{tabular}{|c|c|c|c|c|}
\hline \multicolumn{6}{|c|}{ (Please circle the number) } \\
\hline Not at all & A little & $\begin{array}{c}\text { A moderate } \\
\text { amount }\end{array}$ & Very much & $\begin{array}{c}\text { An extreme } \\
\text { amount }\end{array}$
\end{tabular}

1

2

3

4

5

5. How much do you enjoy life?

F6.1 /

1

2

3

4

5 
For office

use

F24.2 /

F29.1.3

6. To what extent do you feel your life to be meaningful?
(Please circle the number)

\begin{tabular}{|c|c|c|c|c|}
\hline Not at all & A little & $\begin{array}{c}\text { A moderate } \\
\text { amount }\end{array}$ & Very much & $\begin{array}{c}\text { An extreme } \\
\text { amount }\end{array}$
\end{tabular}

1

2

3

4

5
For office

use

F5.2 / 7. How well are you

F7.1.6

able to

concentrate?

F16.1

F20.1.2

8. How safe do you

feel in your daily

life?

F22.1 / 9. How healthy is

F27.1.2 your physical

environment?

\section{(Please circle the number)}

\begin{tabular}{|l|c|c|c|c|}
\hline Not at all & Slightly & $\begin{array}{c}\text { A Moderate } \\
\text { amount }\end{array}$ & Very much & Extremely
\end{tabular}

$\begin{array}{lllll}1 & 2 & 3 & 4 & 5\end{array}$

12

3

4

5

1

2

3

4

5

The following questions ask about how completely you experience or were able to do certain things in the last two weeks.

For office

use

F2.1 / 10. Do you have

F2.1.1

enough energy for

everyday life?

F7.1 / 11. Are you able to accept your bodily appearance?

F18.1/ 12. Have you enough

F23.1.1

\begin{tabular}{|c|c|c|c|c|}
\hline \multicolumn{5}{|c|}{ (Please circle the number) } \\
\hline Not at all & A little & Moderately & Mostly & Completely \\
\hline
\end{tabular}

1

2

3

4

5

1

2

3

4

5

money to meet

your needs?

2

3

4

5 
For office

use

F20.1 / 13. How available to

F25.1.1 you is the information that you need in your day-to-day life?

F21.1 / 14. To what extent do F26.1.2

you have the opportunity for leisure activities?

\begin{tabular}{|l|l|l|l|l|}
\hline \multicolumn{5}{|c|}{ (Please circle the number) } \\
\hline Not at all & A little & Moderately & Mostly & Completely \\
& & & & \\
\hline
\end{tabular}

$\begin{array}{llllll}1 & 2 & 3 & 4 & 5\end{array}$

For office

use

F9.1 /

F11.1.1
15. How well are you able to get around?

\begin{tabular}{|c|c|c|c|c|}
\hline \multicolumn{5}{|c|}{ (Please circle the number) } \\
\hline Very poor & Poor & Neither poor & Well & Very well \\
\hline
\end{tabular}

1
3

The following questions ask you to say how good or satisfied you have felt about various aspects of your life over the last two weeks.

For office use

F3.3 / 16. How satisfied are

F4.2.2 you with your sleep?

F10.3 /

F12.2.3

17. How satisfied are you with your ability to perform your daily living activities?

F12.4 /

F16.2.1
18. How satisfied are you with your capacity for work?
(Please circle the number)

\begin{tabular}{|c|c|c|c|c|}
\hline \multicolumn{5}{|c|}{ (Please circle the number) } \\
\hline $\begin{array}{c}\text { Very } \\
\text { dissatisfied }\end{array}$ & Dissatisfied & $\begin{array}{c}\text { Neither } \\
\text { satisfied nor } \\
\text { dissatisfied }\end{array}$ & Satisfied & $\begin{array}{c}\text { Very } \\
\text { satisfied }\end{array}$ \\
\hline
\end{tabular}

12

3

4

5

12

3

4

5

1

2

3

4

5 
F8.2.2

19. How satisfied are you with yourself?

\begin{tabular}{|c|c|c|c|c|}
\hline \multicolumn{5}{|c|}{ (Please circle the number) } \\
\hline $\begin{array}{c}\text { Very } \\
\text { dissatisfied }\end{array}$ & Dissatisfied & $\begin{array}{c}\text { Neither } \\
\text { satisfied nor } \\
\text { dissatisfied }\end{array}$ & Satisfied & $\begin{array}{c}\text { Very } \\
\text { satisfied }\end{array}$ \\
\hline
\end{tabular}

F13.3 / F17.2.3

20. How satisfied are you with your personal relationships?

F15.3 / 21. How satisfied are F3.2.1 you with your sex life?

1

1

12

2

3

4

5

2

3

4

5

1

2

3

4

5

F14.4 / 22. How satisfied are

1

2

3

4

5 you with the support you get from your friends?

F17.3 /

23. How satisfied are you with the conditions of your living place?

F19.3 / 24. How satisfied are F24.2.1 you with your access to health services?

F.23.3 / 25. How satisfied are F28.2.2 you with your mode of transportation?

1

12

2

3

4

5

1

2

3

4 
The follow question refers to how often you have felt or experienced certain things in the last two weeks.

\begin{tabular}{|c|c|c|c|c|c|c|c|}
\hline \multirow[b]{2}{*}{$\begin{array}{l}\text { For office } \\
\text { use }\end{array}$} & & & \multicolumn{5}{|c|}{ (Please circle the number) } \\
\hline & & & Never & Seldom & $\begin{array}{l}\text { Quite } \\
\text { often }\end{array}$ & $\begin{array}{l}\text { Very } \\
\text { often }\end{array}$ & Always \\
\hline $\begin{array}{c}\text { F8.1 / } \\
\text { F10.1.2 }\end{array}$ & 26. & $\begin{array}{l}\text { How often do you } \\
\text { have negative } \\
\text { feelings, such as } \\
\text { blue mood, despair, } \\
\text { anxiety, } \\
\text { depression? }\end{array}$ & 1 & 2 & 3 & 4 & 5 \\
\hline
\end{tabular}

Did someone help you to fill out this Yes No form? (Please circle Yes or No)

How long did it take to fill out this form?

\section{THANK YOU FOR YOUR HELP}




\section{WHOQOL-BREF Scoring}

The WHOQOL-Bref, still in field trials, is a subset of 26 items taken from the WHOQOL-100. The same steps for the scoring WHOQOL-100 should be followed to achieve scores for the Bref. Although scoring the Bref is identical to scoring the WHOQOL-100, there are some differences that need to be addressed:

- The WHOQOL-Bref does not have facet scores

- Mean substitutions are recommended for Domain 1 Physical Health and Domain 4 Environment if no more than one item is coded missing

- Only three items need to be reversed before scoring

The WHOQOL-Bref (Field Trial Version) produces a profile with four domain scores and two individually scored items about an individual's overall perception of quality of life and health. The four domain scores are scaled in a positive direction with higher scores indicating a higher quality of life. Three items of the Bref must be reversed before scoring. They can be seen in Table 9, indicated by the “- (reverse)" denotation in the Direction of scaling column.

TABLE 9. Scoring Domains of the WHOQOL-BREF

\begin{tabular}{|c|c|c|c|c|}
\hline \multicolumn{2}{|c|}{$\begin{array}{l}\text { Domains and questions } \\
\text { 236/BREF }\end{array}$} & Direction of scaling & $\begin{array}{l}\text { Raw domain } \\
\text { score }\end{array}$ & Raw item score \\
\hline \multicolumn{2}{|c|}{ Overall Quality of Life and General Health } & & $\ldots . .(2-10)$ & \\
\hline G1.1/B1 & How would you rate your quality of life? & + & & $\ldots .(1-5)$ \\
\hline G2.3/B2 & How satisfied are you with your health? & + & & $\ldots(1-5)$ \\
\hline Domain 1 & Physical Health & & $\ldots .(7-35)$ & \\
\hline F1.2.5/B3 & $\begin{array}{l}\text { To what extent do you feel that physical pain prevents you from } \\
\text { doing what you need to do? }\end{array}$ & -(reverse) & & $\ldots .(1-5)$ \\
\hline F13.1.4/B4 & $\begin{array}{l}\text { How much do you need any medical treatment to function in } \\
\text { your daily life? }\end{array}$ & -(reverse) & & $\ldots(1-5)$ \\
\hline F2.1.1/B10 & Do you have enough energy for everyday life? & + & & $\ldots .(1-5)$ \\
\hline F11.1.1/B15 & How well are you able to get around? & + & & $\ldots .(1-5)$ \\
\hline F4.1.1/B16 & How satisfied are you with your sleep & + & & $\ldots .(1-5)$ \\
\hline F12.2.3/B17 & $\begin{array}{l}\text { How satisfied are you with your ability to perform your daily } \\
\text { living activities? }\end{array}$ & + & & $\ldots(1-5)$ \\
\hline F16.2.1/B18 & How satisfied are you with your capacity for work? & + & & $\ldots .(1-5)$ \\
\hline Domain 2 & Psychological & & $\ldots .(6-30)$ & \\
\hline F6.1.2/B5 & How much do you enjoy life? & + & & $\ldots .(1-5)$ \\
\hline F29.1.3/B6 & To what extent do you feel your life to be meaningful? & + & & $\ldots .(1-5)$ \\
\hline F7.1.6/B7 & How well are you able to concentrate? & + & & $\ldots .(1-5)$ \\
\hline F9.1.2/B11 & Are you able to accept your bodily appearance? & + & & $\ldots .(1-5)$ \\
\hline F8.2.1/B19 & How satisfied are you with yourself? & + & & $\ldots(1-5)$ \\
\hline F10.1.2/B26 & $\begin{array}{l}\text { How often do you have negative feelings such as blue mood, } \\
\text { despair, anxiety, depression? }\end{array}$ & - (reverse) & & $\ldots(1-5)$ \\
\hline Domain 3 & Social relationships & & ....(3-15) & \\
\hline F17.1.3/B20 & How satisfied are you with your personal relationships? & + & & $\ldots .(1-5)$ \\
\hline F3.2.1/B21 & How satisfied are you with your sex life? & + & & $\ldots(1-5)$ \\
\hline F18.2.5/B22 & How satisfied are with the support you get from your friends? & + & & $\ldots .(1-5)$ \\
\hline
\end{tabular}

WHOQOL Manual-Body.doc, updated 10/12/2005, 4:14 PM 


\begin{tabular}{|c|c|c|c|c|}
\hline \multicolumn{2}{|c|}{$\begin{array}{l}\text { Domains and questions } \\
\text { 236/BREF }\end{array}$} & Direction of scaling & $\begin{array}{l}\text { Raw domain } \\
\text { score }\end{array}$ & Raw item score \\
\hline Domain 4 & Environment & & $\ldots .(8-40)$ & \\
\hline F20.1.2/B8 & How safe do you feel in your daily life? & + & & $\ldots(1-5)$ \\
\hline $\mathrm{F} 27.1 .2 / \mathrm{B} 9$ & How healthy is your physical environment? & + & & $\ldots(1-5)$ \\
\hline F23.1.1/B12 & Have you enough money to meet your needs? & + & & $\ldots(1-5)$ \\
\hline F25.1.1/B13 & $\begin{array}{l}\text { How available to you is the information that you need in your } \\
\text { daily-to-day life? }\end{array}$ & + & & $\ldots .(1-5)$ \\
\hline F26.1.2/B14 & To what extent do you have the opportunity for leisure activities? & + & & $\ldots(1-5)$ \\
\hline F21.2.2/B23 & How satisfied are you with the condition of your living place? & + & & $\ldots(1-5)$ \\
\hline F24.2.1/B24 & How satisfied are you with your access to health services? & + & & $\ldots(1-5)$ \\
\hline F28.2.2/B25 & How satisfied are you with your transport? & + & & $\ldots(1-5)$ \\
\hline
\end{tabular}

If no more than one item from the Physical Health or Environment domains has been coded as missing, we recommend that a domain score be calculated by substituting a personspecific average across the completed items in the same scale. For example, if a respondent does not have a value for item B16 How satisfied are you with your sleep? in the Physical Health domain, but has answered all of the other items in that domain, then the value for item B16 would be the average of the remaining 6 items. If two or more items are coded missing in these two domains, the domain score should not be calculated, likewise if any items are coded missing in the Psychological and Social Relationships domains, a domain score for that respondent would not be calculated.

After item recoding and handling of missing data, a raw score is computed by a simple algebraic sum of each item in each of the four domains. Once complete, check the frequencies of each domain to be sure that the scores are within the correct range indicated in Table 9 Raw domain score column. The next step is to transform each raw scale score using the formula on page 31. The possible raw score ranges for each domain are as follows: Physical Health=28, Psychological=24, Social Relationships=12, and Environment=32.

\section{SCORING EXERCISE AND TEST DATASET FOR THE WHOQOL-BREF INSTRUMENT}

The purpose of this scoring exercise is to help WHOQOL-Bref users to evaluate results from each step in the process of calculating the Domain summary scores of the instrument. This exercise was created for SPSS users, but with minor modifications, can be adapted for other computer programs or can be useful for those scoring the survey manually.

A test dataset and SPSS code for scoring the WHOQOL-Bref a computer diskette in this packet. The test dataset, which is called "WQ_BREF.TXT" on the diskette, contains data from 64 administrations of the WHOQOL-BREF. The data can be seen in Appendix F. The enclosed diskette also provides the user with the SPSS syntax used to:

- $\quad$ import raw data into SPSS format [WQ_B_DL.SPS]

- $\quad$ derive the WHOQOL-BREF domain summaries [WQ_BREF.SPS]

The SPSS code (called “WQ_BREF.SPS”) on the diskette begins by labeling all items and checking for out-or-range values. It then recodes the 3 negatively stated items so that a 
higher score indicates better health. The 4 domains are then scored, labeled, and transformed to a 0 to 100 scale used to interpret and compare to other validated instrument tools such as the WHOQOL-100. A copy of the SPSS syntax is reproduced in Appendix F.

Table 10 presents statistics for the transformed domains for the WHOQOL-Bref. After scoring the test dataset, the means, standard deviations, and minimum and maximum observed values should agree with those presented in Table 10

\section{TABLE 10. Test Dataset Descriptive Statistics: WHOQOL-BREF}

\section{Descriptive Statistics}

\begin{tabular}{lccccc}
\hline \hline & $\mathrm{N}$ & Minimum & Maximum & Mean & $\begin{array}{c}\text { Std. } \\
\text { Deviation }\end{array}$ \\
\hline $\begin{array}{l}\text { Physical } \\
\text { (TRANSFORMED) }\end{array}$ & 64 & 32.14 & 92.86 & 66.7969 & 14.5480 \\
$\begin{array}{l}\text { Psychological } \\
\text { (TRANSFORMED) }\end{array}$ & 64 & 37.50 & 95.83 & 73.5026 & 13.7165 \\
$\begin{array}{l}\text { Social Relations } \\
\text { (TRANSFORMED) }\end{array}$ & 64 & 25.00 & 100.00 & 73.1771 & 17.0891 \\
$\begin{array}{l}\text { Environment } \\
\text { (TRANSFORMED) }\end{array}$ & 64 & 28.13 & 100.00 & 72.8027 & 14.1592 \\
Valid N (listwise) & 64 & & & & \\
\hline \hline
\end{tabular}


After all necessary items have been recoded, a raw score is calculated for each facet and each domain. Both facets and domains are scored through a simple algebraic summation of each item in that scale. As stated earlier, each question contributes equally to the facet score and each facet contributes equally to the domain score. Since each facet has four items with response values of 1 through 5, the raw score for any facet must have a minimum value of 4 and a maximum value of 20 (see Table 7 on the following pages).

\section{TRANSFORMATION OF SCALE SCORES}

The next step involves transforming each raw scale score to a $0-100$ scale using the formula shown below:

$$
\text { Transformed Scale }=\left[\frac{(\text { Actual raw score }- \text { lowest possible raw score })}{\text { Possible raw score range }}\right] \times 100
$$

where "Actual raw score" is the values achieved through summation, "lowest possible raw score" is the lowest possible value that could occur through summation (this value would be 4 for all facets), and "Possible raw score range" is the difference between the maximum possible raw score and the lowest possible raw score (this value would be 16 for all facets: 20 minus 4).

This transformation converts the lowest and highest possible scores to zero and 100 , respectively. Scores between these values represent the percentage of the total possible score achieved. The WHOQOL-100 scores from other Centers may not be transformed to the $0-100$ scale. The U.S.WHOQOL instruments and scoring programs have used this transformation to provide comparative data for interpretation.

Example: A Facet 1 "Pain and discomfort" raw score of 15 would be transformed as follows:

$$
\text { Transformed Scale }=\left[\frac{(15-4)}{16}\right] \times 100=68.75
$$


Appendix 3: Garden Diaries 
Fecha

Nombre Lote

\section{Diario de Jardín}

\begin{tabular}{|l|l|l|l|l|l|l|}
\hline $\mathrm{L}$ & $\mathrm{M}$ & $\mathrm{M}$ & $\mathrm{J}$ & $\mathrm{V}$ & $\mathrm{S}$ & $\mathrm{D}$ \\
\hline & & & & & & \\
\hline & & & & & & $*$ \\
\hline
\end{tabular}

Por favor complete las siguiente información cada Domingo.

\section{INFORMACION GENERAL}

A ¿Cómo estuvo el clima la última semana? marque una respuesta $\bigotimes$

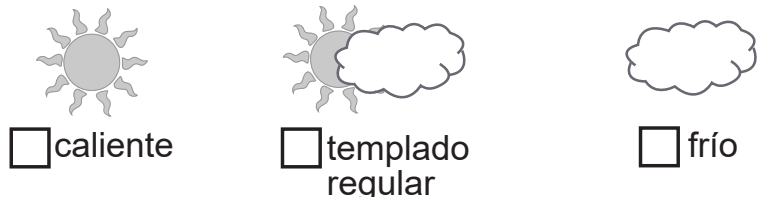

B ¿Quién cuidó el jardín la última semana? marque una o varias respuestas $\square$
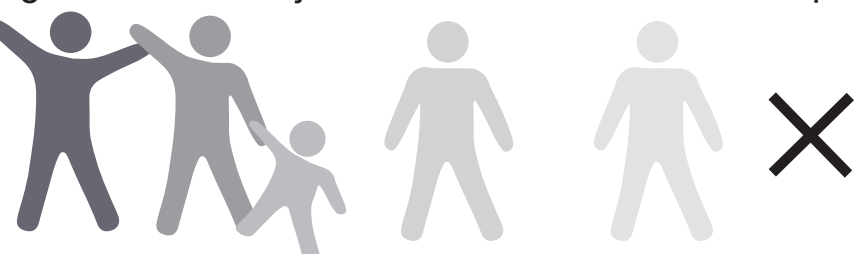

usted su pareja su hijo(a) familiar amigo/vecino nadie

\section{ATENCION DEL JARDIN}

(A) ¿Qué días de la semana cuidó su jardín? marque una o varias respuestas $\square$

\begin{tabular}{|l|l|l|l|}
\hline Lunes $\square$ Martes $\square$ Miércoles $\square$ Jueves $\square$ Viernes $\square$ Sábado $\square$ Domingo \\
\hline
\end{tabular}

B ¿En promedio cuánto toma cuidar su jardin? marque una respuesta $\unrhd$

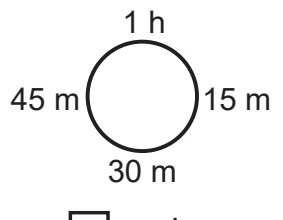

$\square$ nada

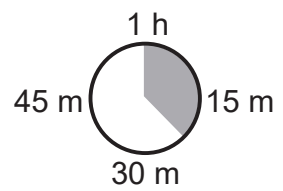

menos de 30 minutos

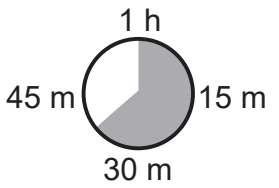

$\square$ mas de 30

(C) ¿Le gustaría tener más tiempo para cuidar su jardín? marque una respuesta $\bigotimes$ mas tiempo el mismo tiempo menos tiempo

D ¿Cómo cuido su jardín esta semana? marque una o varias respuestas, diga cuantas veces

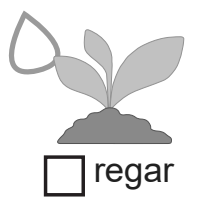

¿Cuántas veces a la semana?

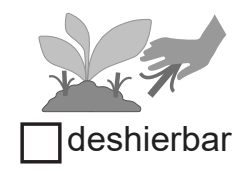

¿Cuántas veces a la semana?

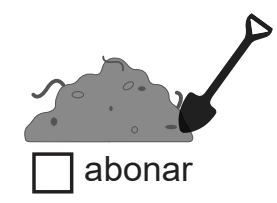

¿Cuántas veces a la semana?

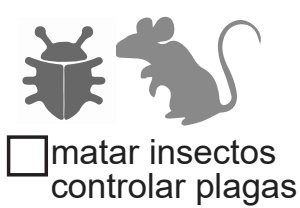

¿Cuántas veces a la semana?

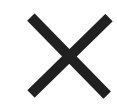

otra (¿cuál?)

¿Cuántas veces a

la semana?

(E) Si usted regó, ¿Cuánta agua gasto? marque una respuesta $\square$
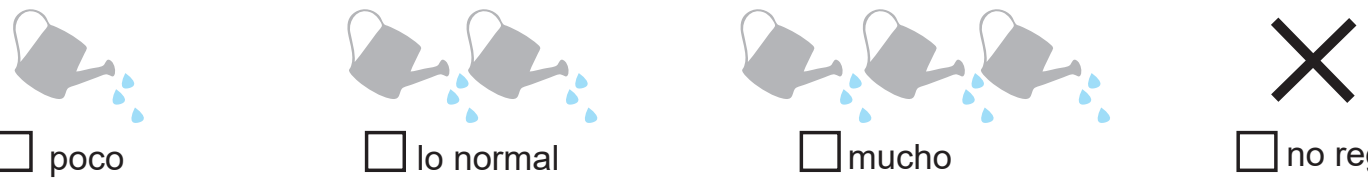

$\square$ no regué 


\section{INFORMACION DE PLANTAS}

(A) ¿Cuántas plantas
murieron esta
semana?
frutales
(B) $\begin{gathered}\text { iCuántas plantas } \\ \text { nuevas ha } \\ \text { plantado? }\end{gathered}$

(C) ¿Ha cosechado algo esta semana? $\square$ Si $\square$ No

Si cosechó, ¿Qué cosechó y cuantó?

D Si cosecho algo, ¿Qué hizo con la cosecha? marque una o varias respuestas $\bigotimes$
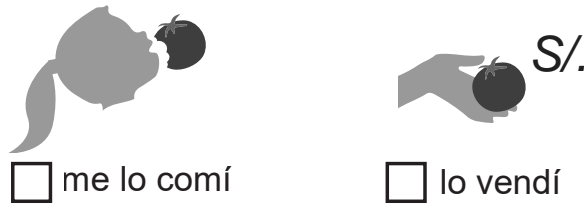

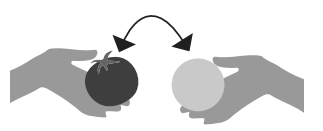

$\square$ lo cambié

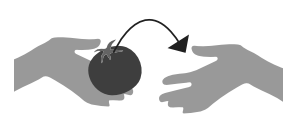

$\square$ lo regalé

\section{IMPACTO DEL JARDIN}

A ¿Cómo pasó tiempo con su jardín? marque una o varias respuestas $\bigotimes$
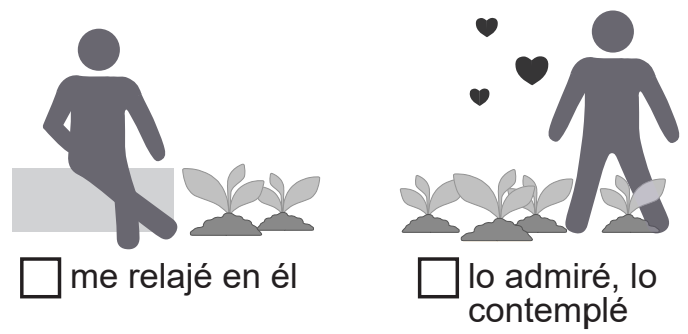

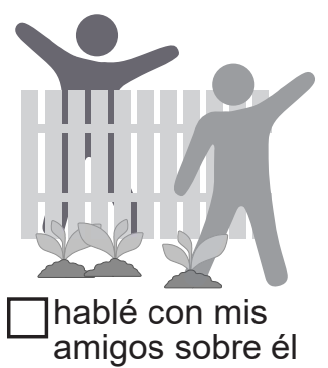

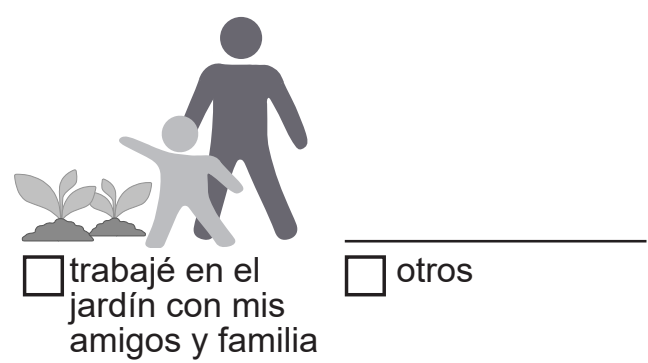

(B) ¿Cómo te sientes respecto al jardin. marque una respuesta $\square$
$\square$ me gusta tal y como está
$\square$ me gustaría cambiarle algunas cositas
$\square$ me gustaría cambiarle varias cosas un jardín 
Construction and Maintenance Manuals

Appendix 4: Household Gardens Maintenance Manual 


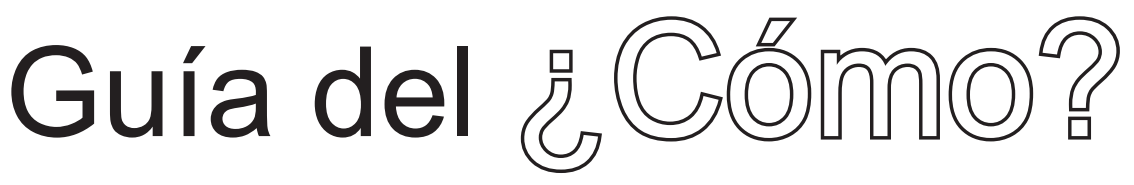 en tu jardín}

¿Cómo plantar?

\section{¿Cómo mantener?}

\section{¿Cómo hacer compost?}

\section{¿Cómo informarme?}

Proyecto jardines, espacios verdes y salud en los asentimientos humanos de Lima Perú, Universidad de Washington y Universidad Nacional Mayor de San Marcos, Septiembre 2013

Manual producido por la Universidad de Washington, Adaptación de "Home Gardening in Lomas de Zapallal, a how to manual”, June 2013 


\section{¿Cómo plantar?}

1. Herramientas recomendadas:

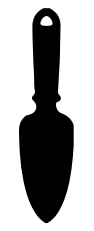

ESPATULA

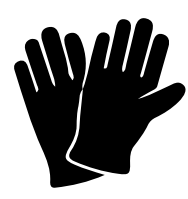

GUANTES

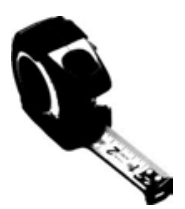

WINCHA

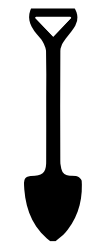

PALA

\section{Preparación de tierra:}

Es necesario que las plantas tengan tierra adecuada para que puedan crecer.

La tierra para jardin o chacra se puede comprar en tiendas (revisar guia de

Tambien uno puede preparar su propia tierra. Para terrenos como Collazos remendamos la siguiente mezcla:

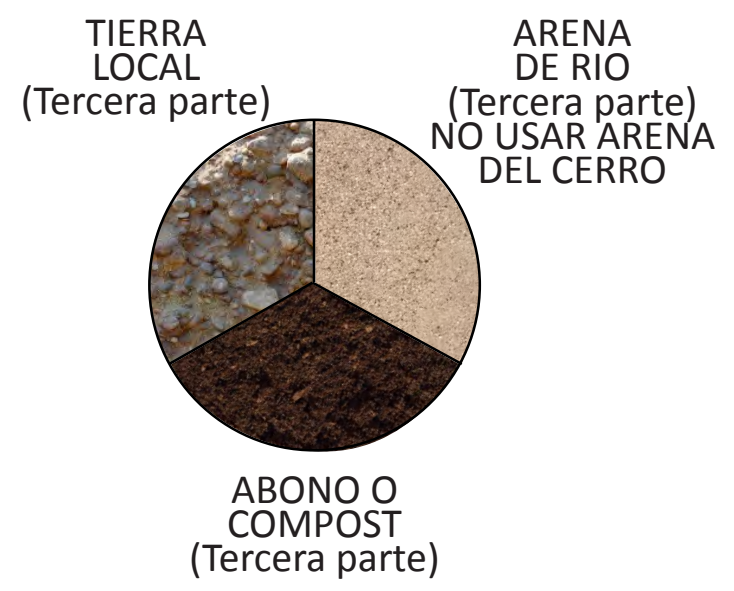

TIERRA

parte

DE RIO (Tercera parte) O USAR ARENA

DEL CERRO
COMPOST

(Tercera parte)

\section{Excavar, colocar la planta y enterrar}

Cada planta necesita un espacio en la tierra para poder crecer. Las plantas mas grandes necesitan huecos mas grandes, las mas chicas necesitan huecos mas chicos. A continuación te recomendamos algunas dimensiones.

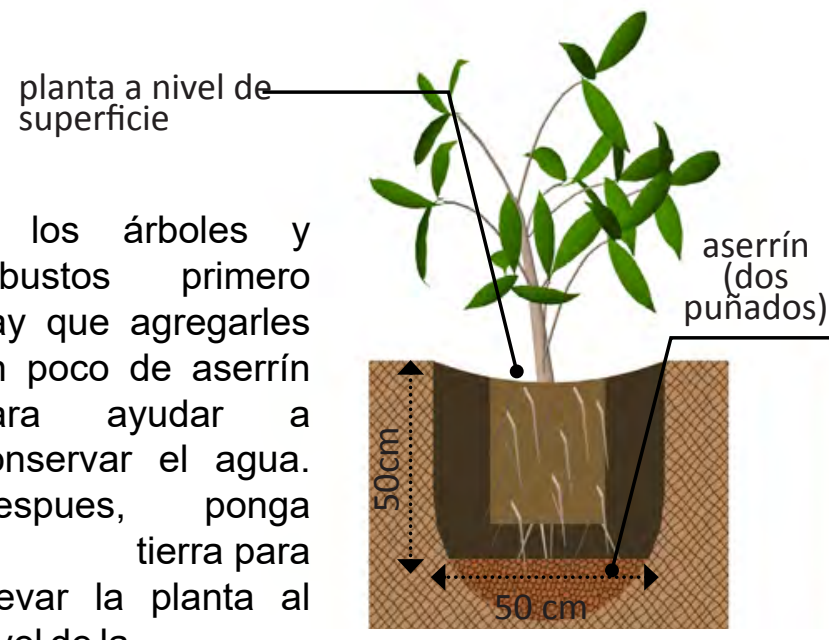

ARBOLES

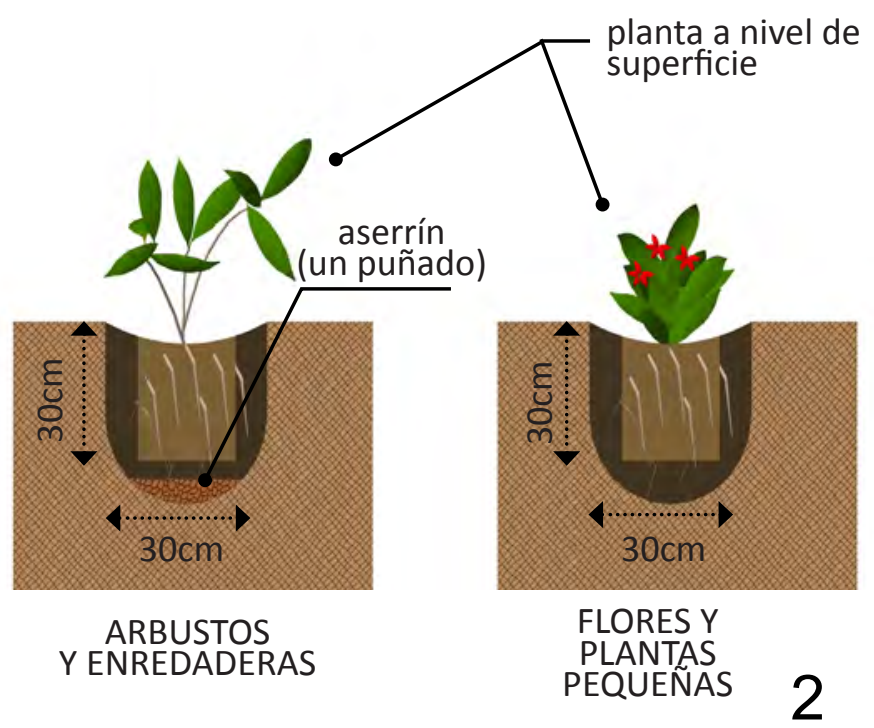




\section{¿Cómo plantar?}

\section{4. ¿Y cómo hago con la papa?:}

Para plantar papa se necesita una papa. Usa papas frescas y medianas. Si vas a plantar varias papas, sepáralas $30 \mathrm{~cm}$. una de otra.

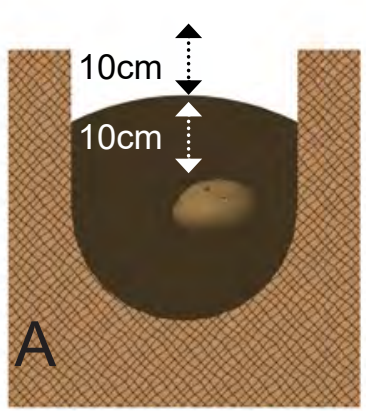

Planta la papa a Espera a que la papa $20 \mathrm{~cm}$ bajo el suelo.

Solo cubre $10 \mathrm{~cm}$ con tierra.

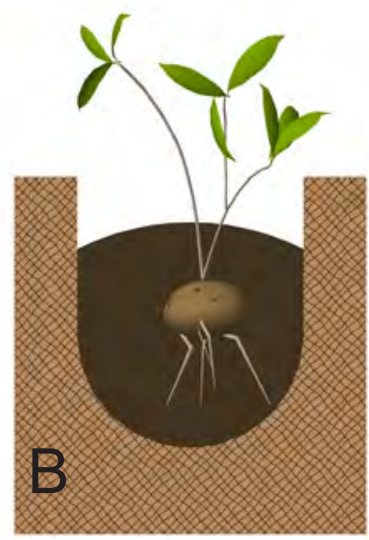

crezca un poco.

\section{5. ¿Y cómo hago con las semillas?:}

A.

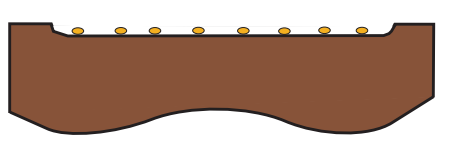

Esparsa las semillas

D.

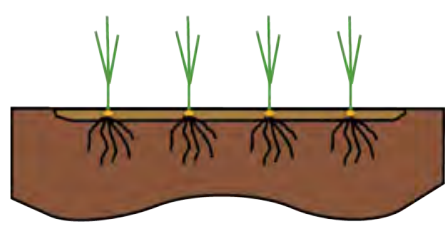

... se recomienda espaciar los cultivos

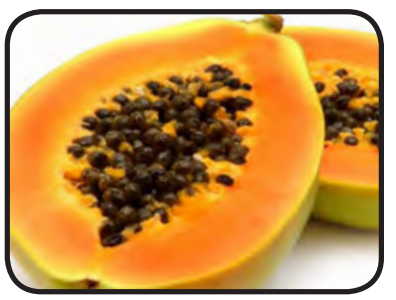

B.

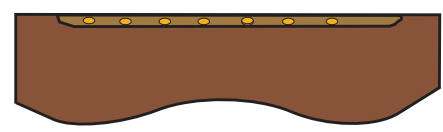

cubra con una capa de tierra de NO MAS DE $1 \mathrm{CM}$, la lechuga no necesita cubrirse.

E.
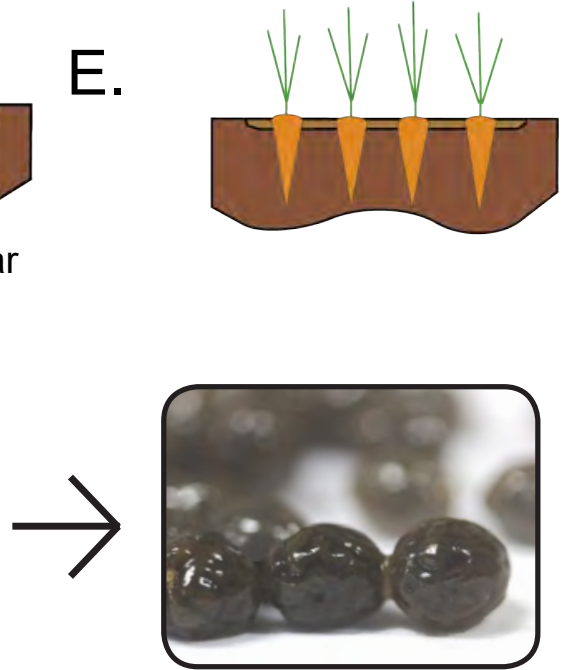

C.

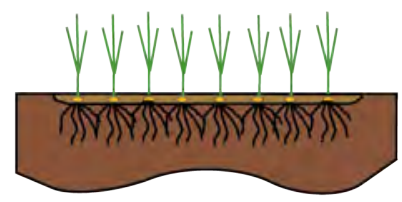

cuando salgan las primeras hojas...
F.

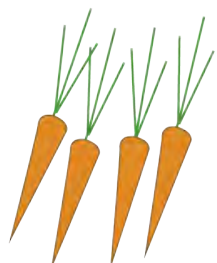

coseche cuidadosamente

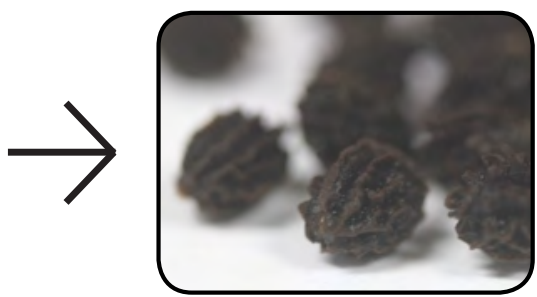

Para las semillas de papaya...

Quita la cascara de gelatina de cada semilla. La eliminación de la cascara es muy importante. Limpia las semillas y sécalas en un lugar con sombra. Planta las semillas, cuatro por cada agujero y no usa abono. Mantenga las plantas pequeñas bien húmedas. 
6. ¿Cómo deshierbar?

Siempre revise si aparecen malas hierbas en su jardin. Quita las hierbas desde su raíz.

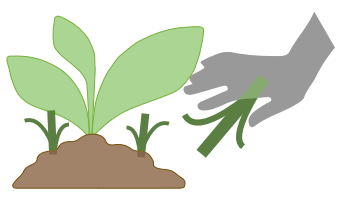

\section{7. ¿Qué agua puedo usar para regar mis plantas?}

NOUSAR

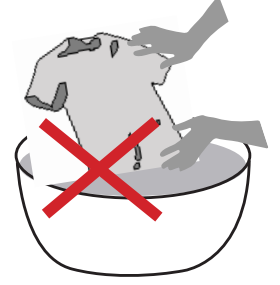

AGUA CON

DETERGENTE, JABON

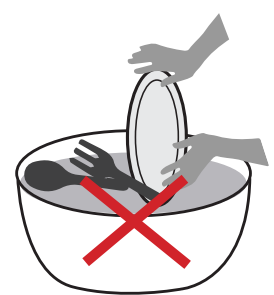

AGUA DE

COCINA, DE

PLATOS, CON

GRASA

SI USAR

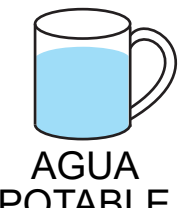

POTABLE

AGUA DESPUES

DE LAVAR FRUTAS,

VERDURAS

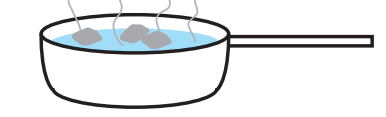

AGUA DESPUES

DE HERVIR

HUEVOS, PAPAS

(DEJAR ENFRIAR)

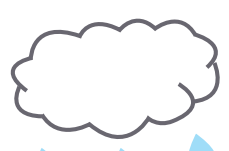

AGUADE LLUVIA, NEBLINA

\section{8. ¿Cómo puedo regar subterraneamente?}

Una opción de riego subterráneo es el riego por capilaridad. Este sistema moja la tierra desde el fondo hacia arriba. Esto ahorra mucha agua. A continuación le presentamos el esquema de como hacerlo.

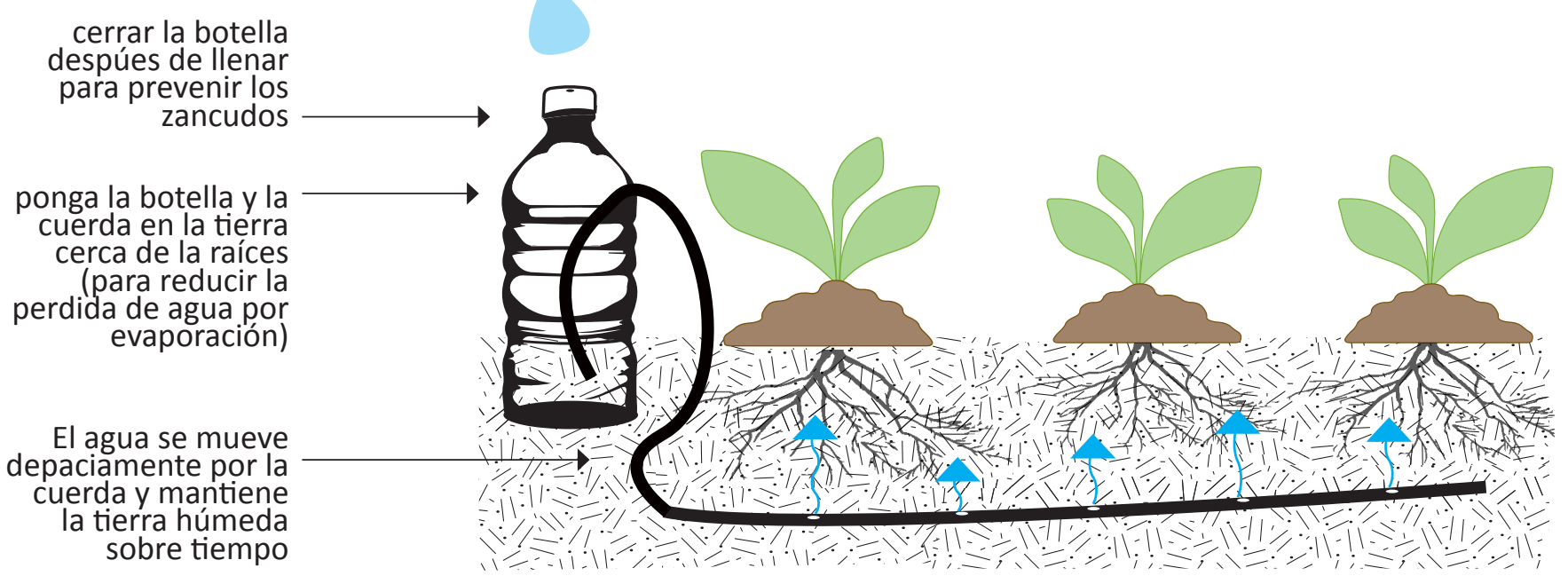

TOMAR EN CUENTA:

Llena con agua hasta que empiece a salir por el tuberia de drenaje.

Llena la tuberia entera una vez por semana o cuando no halla mucha agua.

A las plantas jovenes y semillas, REGAR POR ARRIBA, ya que las raíces son pequeñas y no llegan al fondo. 


\section{¿Cómo mantener?}

9. ¿Qué hacer luego de plantar?

Como la tierra esta seca, necesita echar mucha agua las primeras dos semanas. A continuación te decimos cuanta agua para cada tipo de planta en las primeras dos semanas:
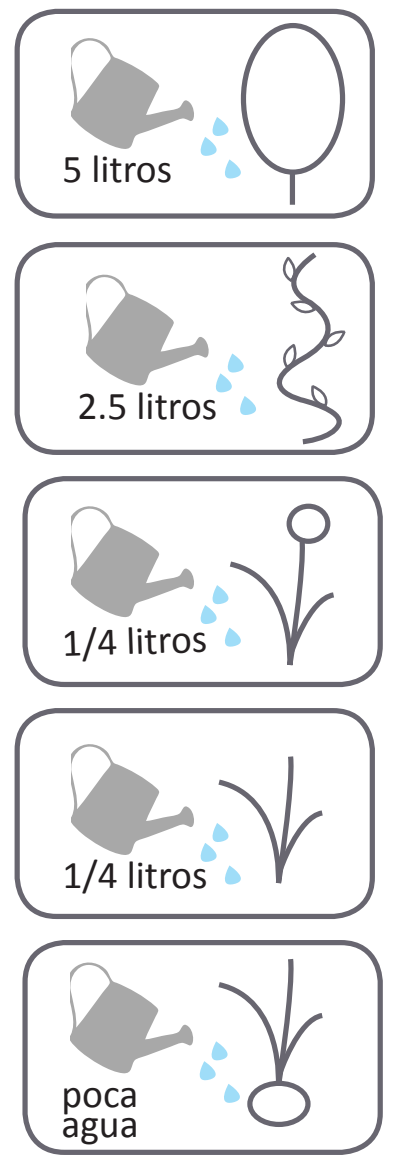

Arboles decorativos / Arboles frutales:

Primera semana 5 litros/ interdiario

Segunda semana 5 litros / 2 veces por semana

Arbustos y enredaderas:

Primera semana 2.5 litros/ interdiario

Segunda semana 2.5 litros / 2 veces por semana

Flores:

Primera semana: 1/4 de litro/ todos los días

\section{Hierbas:}

Primera semana: 1/4 de litro/ todos los días

\section{Semillas de vegetales:}

Humedecer un poco la tierra todos los dias hasta que crezcan las primeras hojas

\section{0. ¿Cómo debo regar mis plantas normalmente?}

En las siguientes páginas tenemos una lista de plantas. En esta lista explicamos cada cuanto hay que regar en cada estación y las características de las plantas. Todas las plantas tienen el siguiente recuadro:

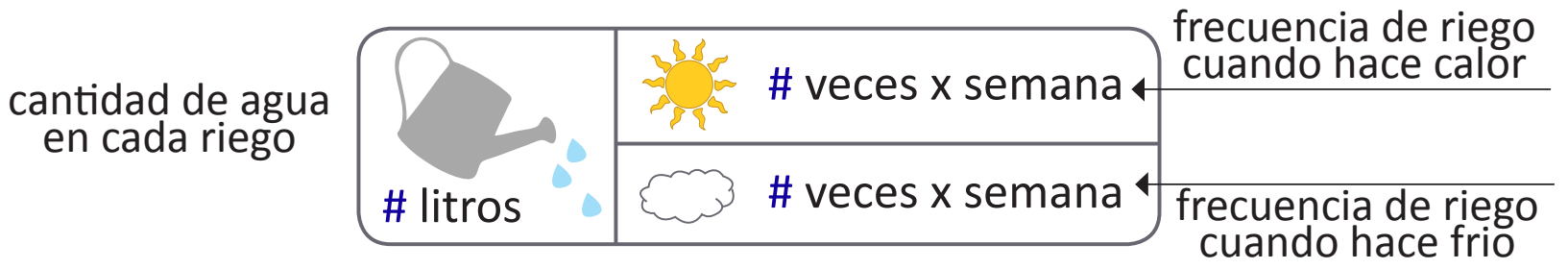

EL MEJOR MOMENTO PARA REGAR ES TEMPRANO EN LAS MAÑANAS O EN LAS NOCHES, PARA QUE EL SOL NO EVAPORE EL AGUA 

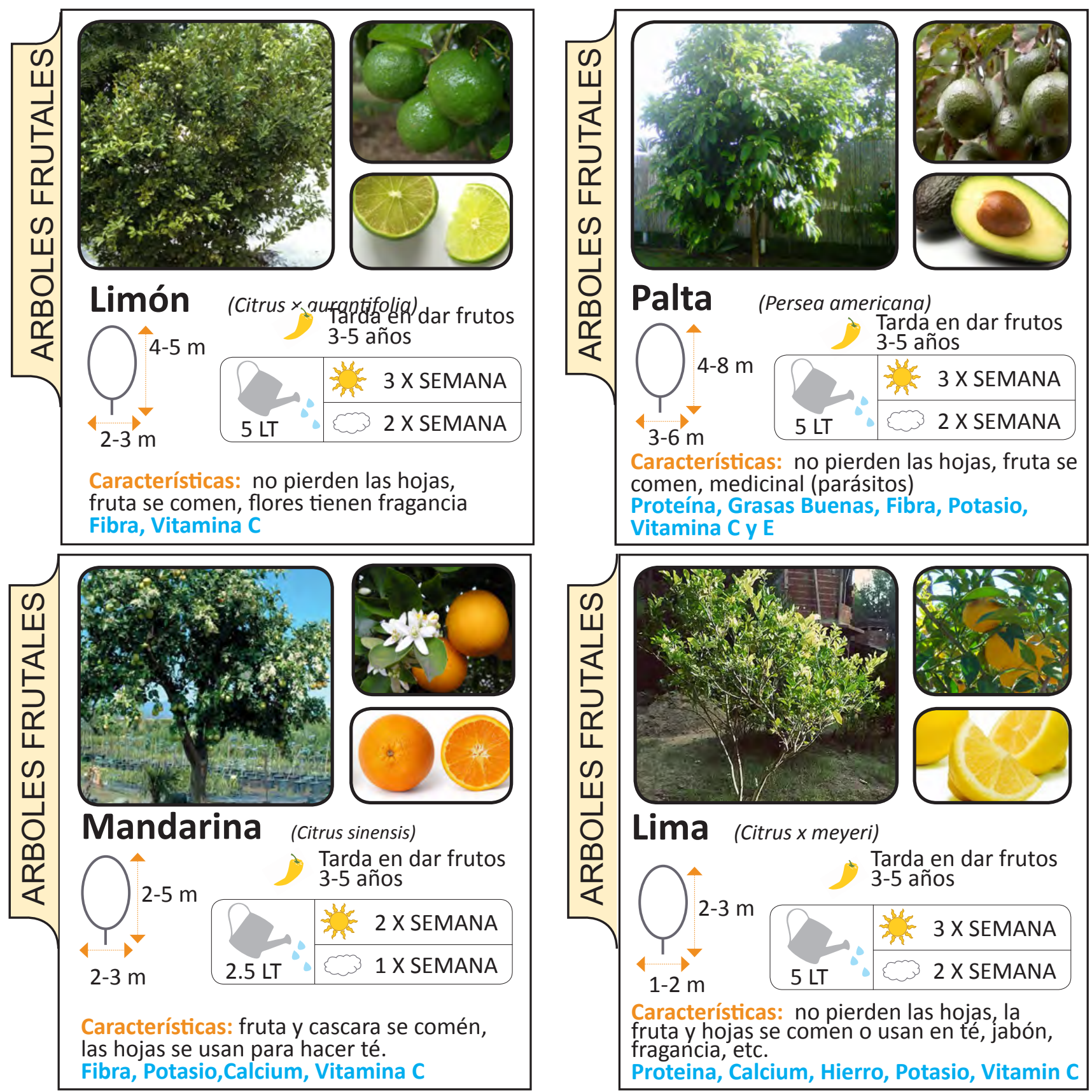

\section{Lima (Citrus $x$ meyeri)}

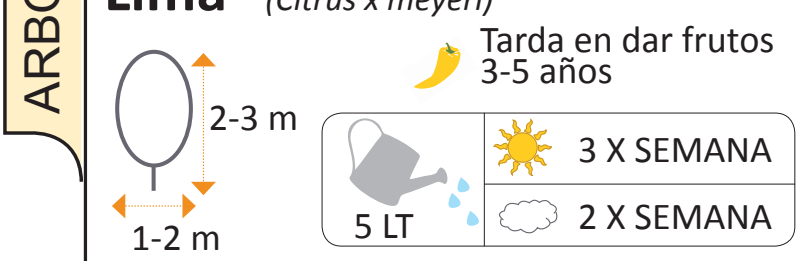

Características: no pierden las hojas, la

fruta y hojas se comen o usan en té, jabón, fragancia, etc.

Proteina, Calcium, Hierro, Potasio, Vitamin C
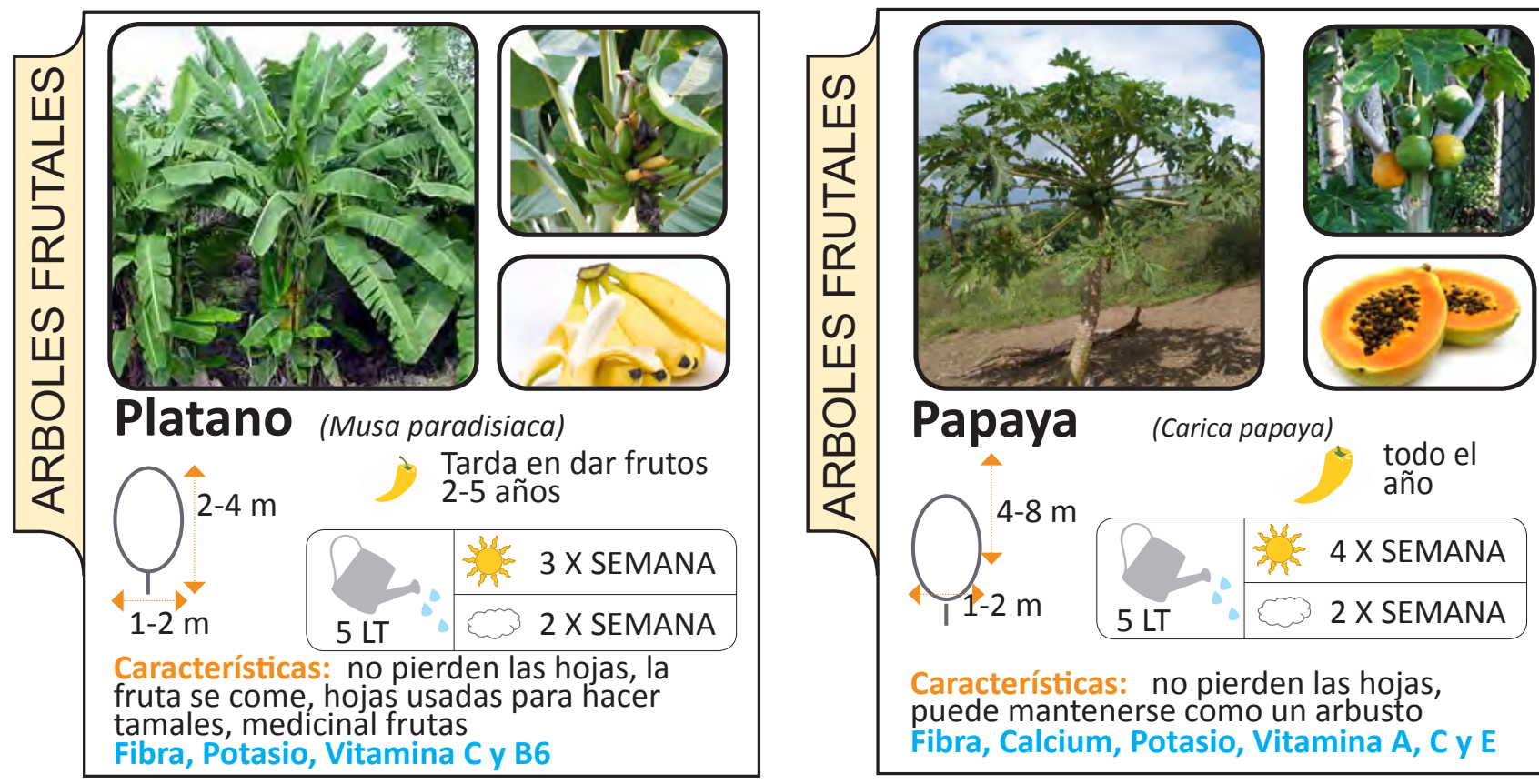

Características: no pierden las hojas, puede mantenerse como un arbusto

Fibra, Calcium, Potasio, Vitamina A, C y E 

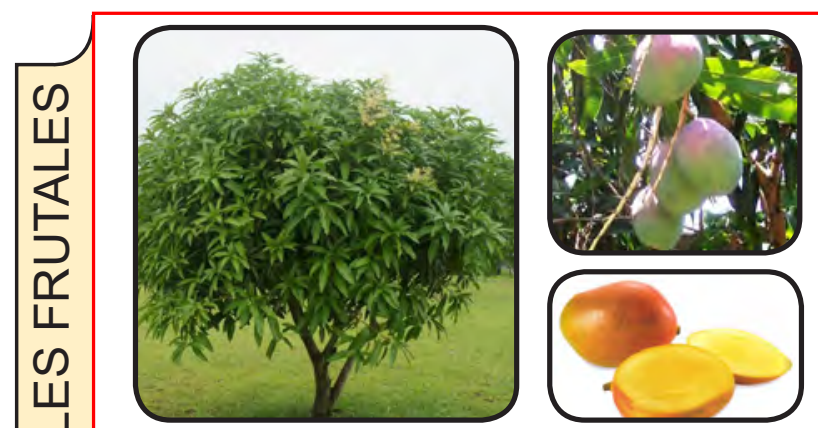

Mango

(Mangifera indica)
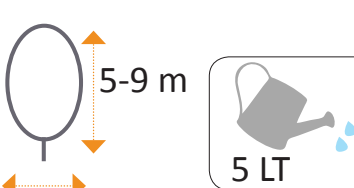

$5 \mathrm{LT}$

3 Abr-Jul

3 X SEMANA

2 X SEMANA

Características: fruta se come (nota: partes de esta planta son toxicas si se comen) Fibra, Potasio, Vitamina A, C, E y B6
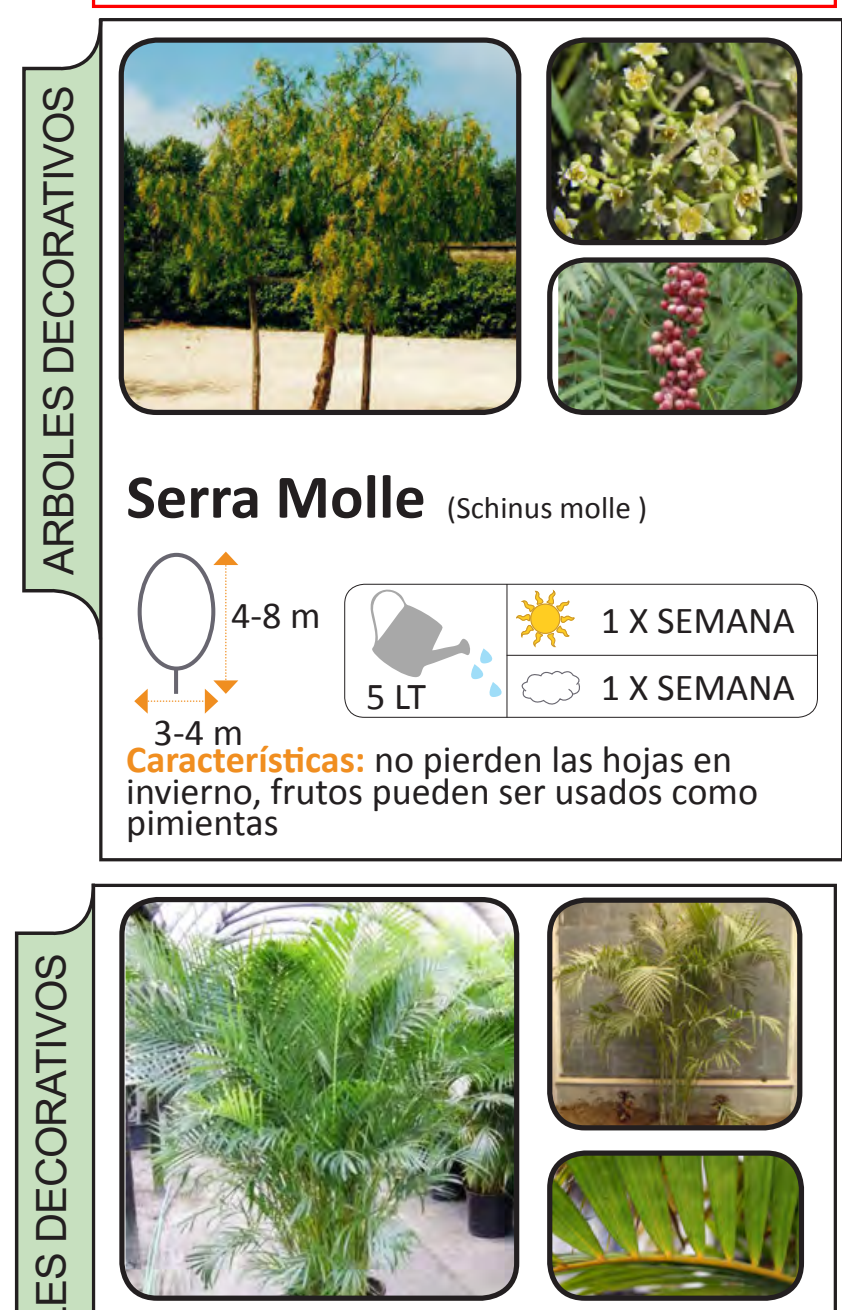

Palmera Fénix (Phoenix cactylifera)<smiles>CC1CCCCCC1=[SeH]</smiles>

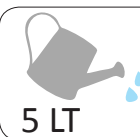

4 X SEMANA

1-2m

$5 \mathrm{LT}$

$2 \times$ SEMANA

Características: no pierden las hojas, viven largo tiempo sin agua, puede mantenerse como un arbusto
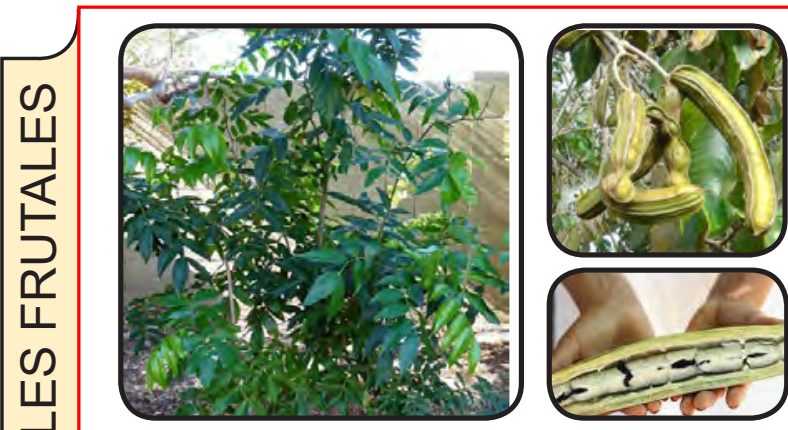

Pacai, Hauba (Ingafeuillei)

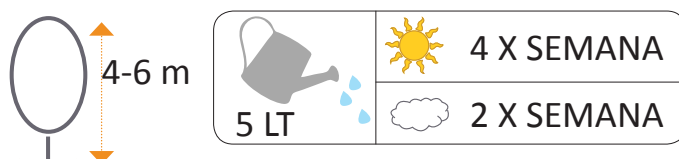
$4 \rightarrow$

3-6 m

Características: no pierden las hojas, fruta y semilla se comen, abona tierra

Proteina ,Antioxidante, Vitamina A
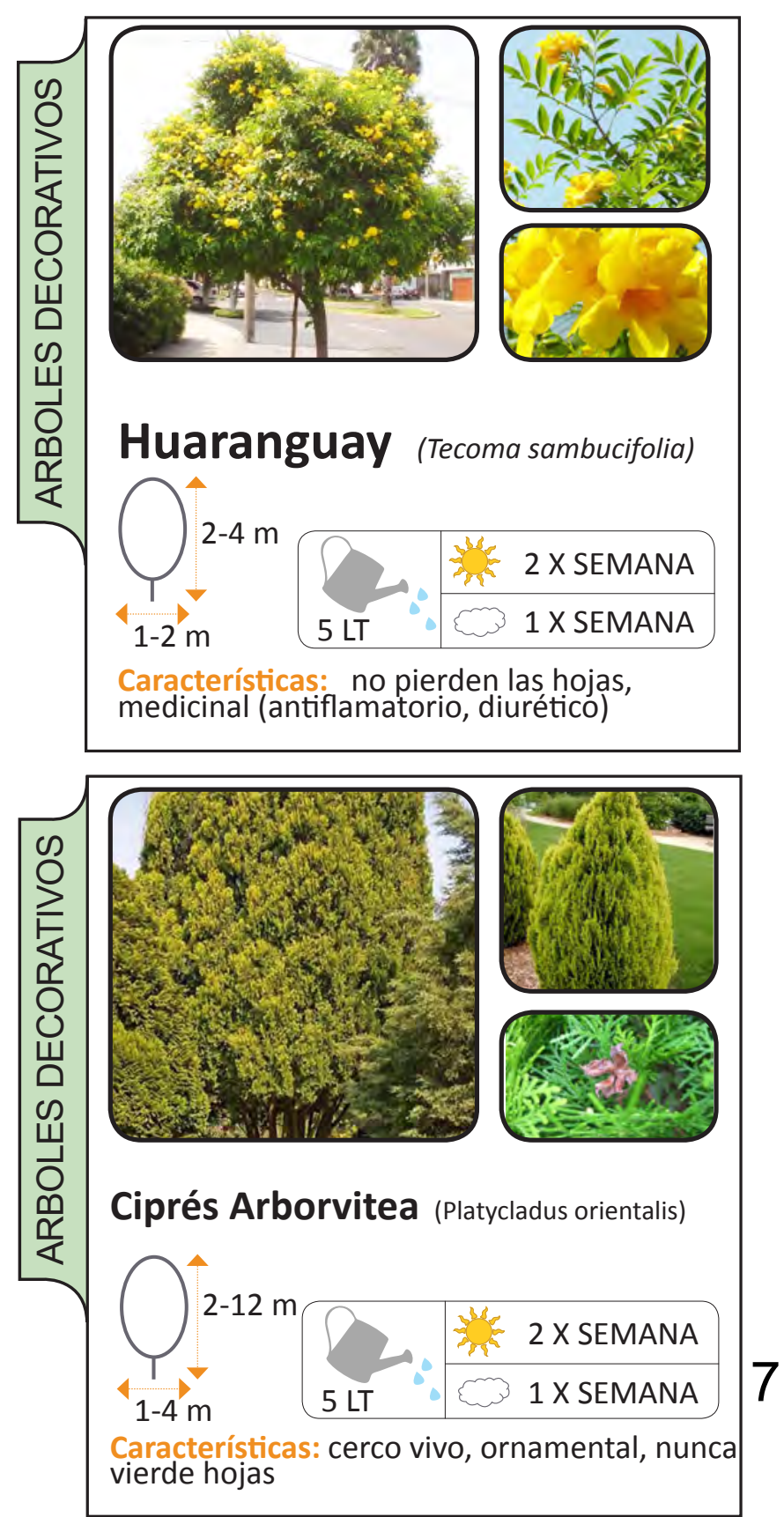

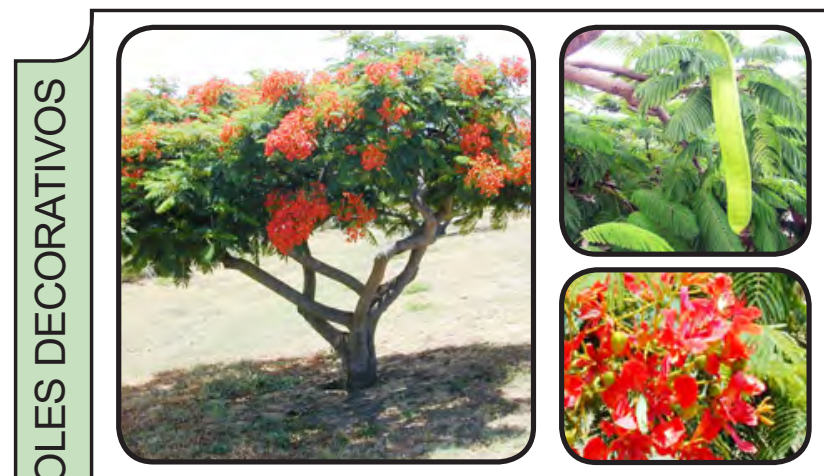

Ponciana (Delonix regia)
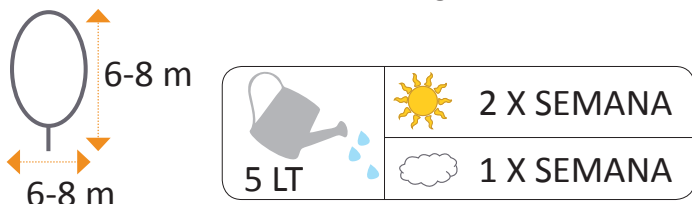

Características: pueden perder hojas en invierno, semillas usadas como instrumento de musica
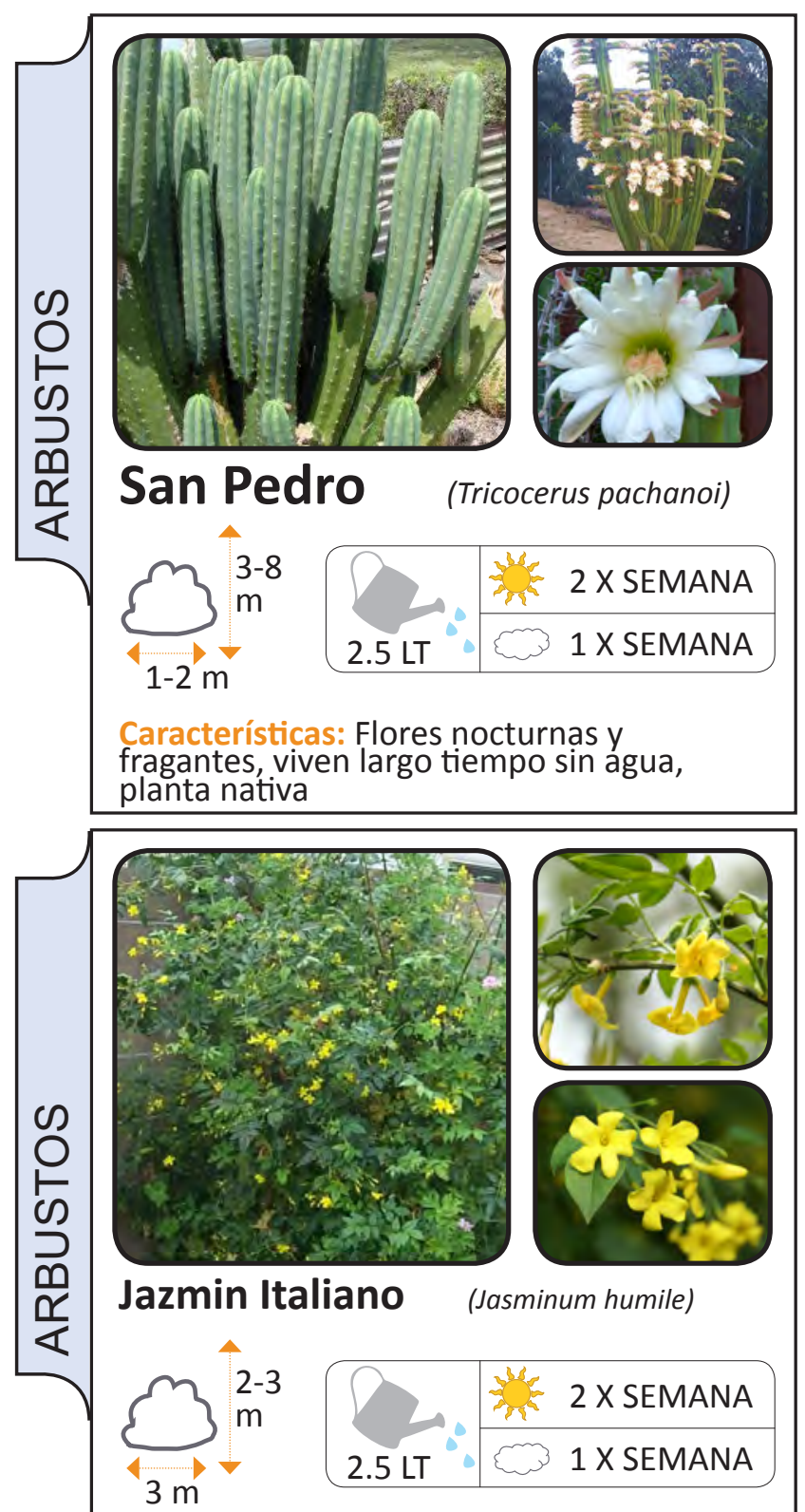

Características: decorativo, puede hacer té con las hojas, propiedades medicinales)

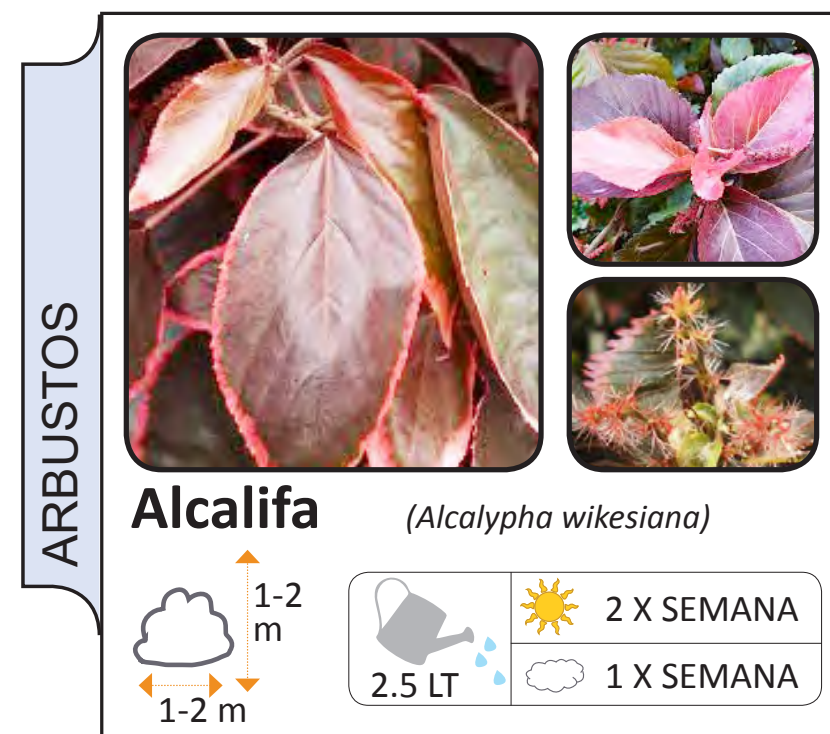

Características: no pierden las hojas, medicinal para la piel
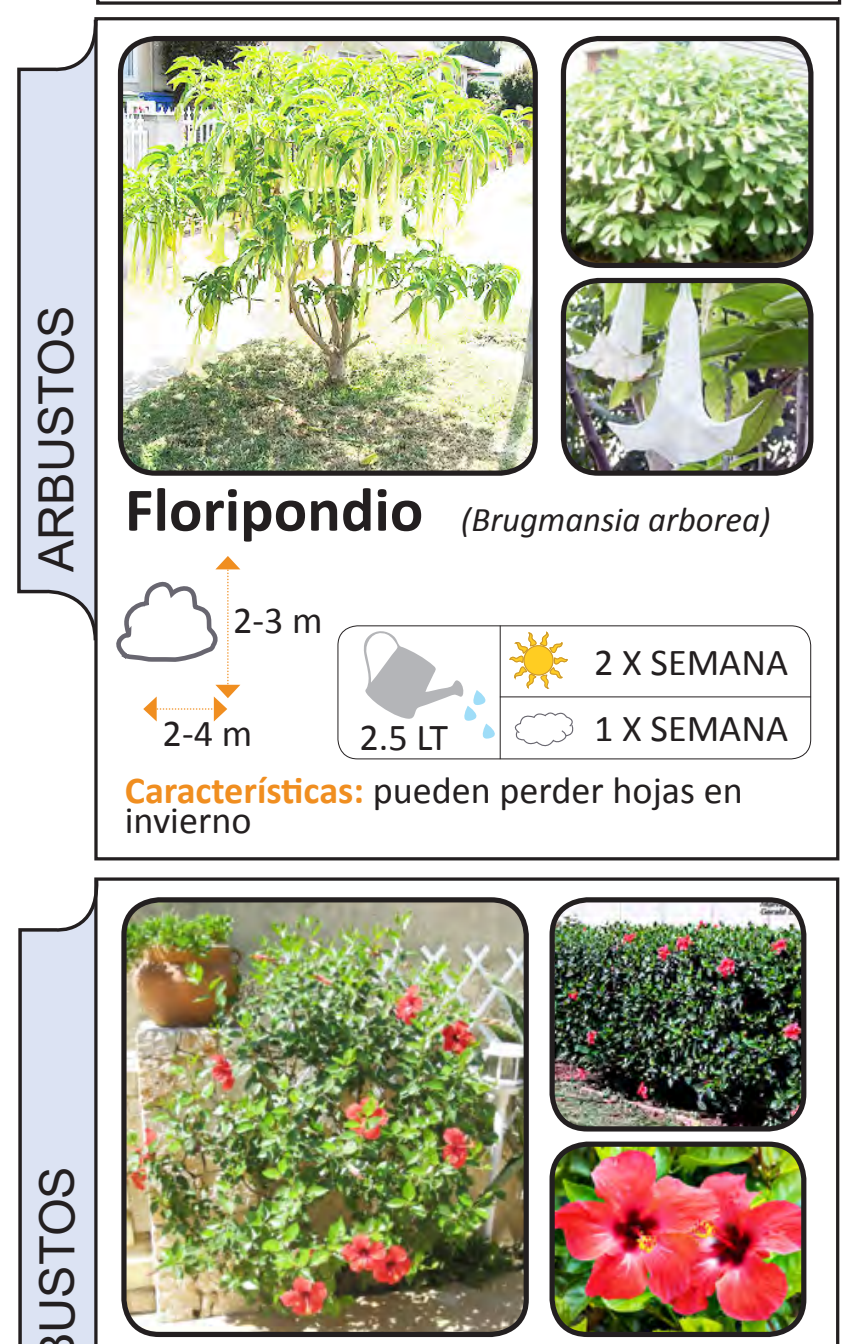

\section{Cucarda (Hibiscus rosa-sinensis)}

$\sum_{1-3 \mathrm{~m}}^{m} 2-5 \mathrm{~m} \overbrace{2.5 \mathrm{LT}} \cdot \frac{P^{3}}{2 \times \text { SEMANA }}$

Características: no pierden las hojas, hojas tienen fragancia, flores secas usadas en té (diuretico, bajar tension) 

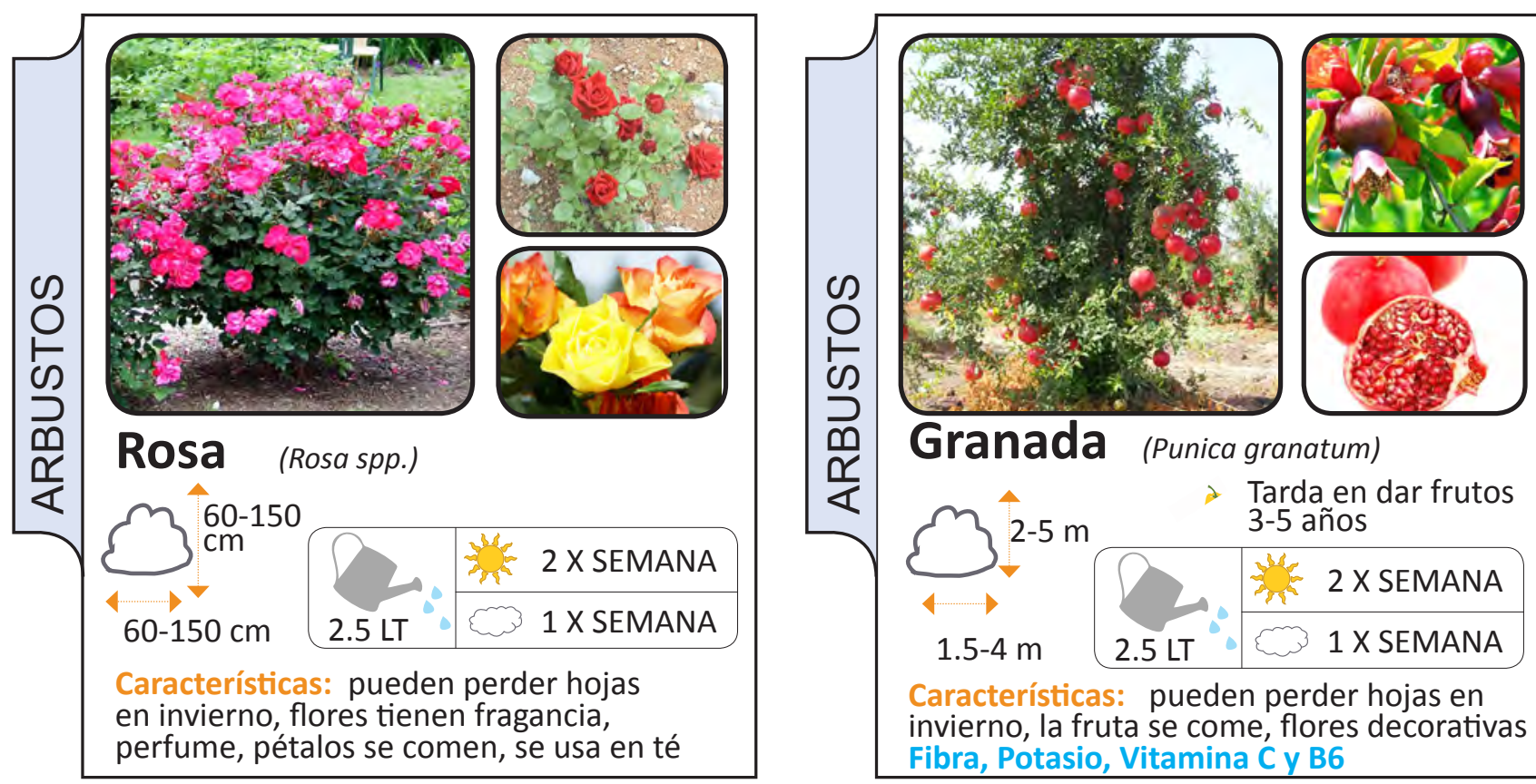

Características: pueden perder hojas en invierno, la fruta se come, flores decorativas Fibra, Potasio, Vitamina C y B6
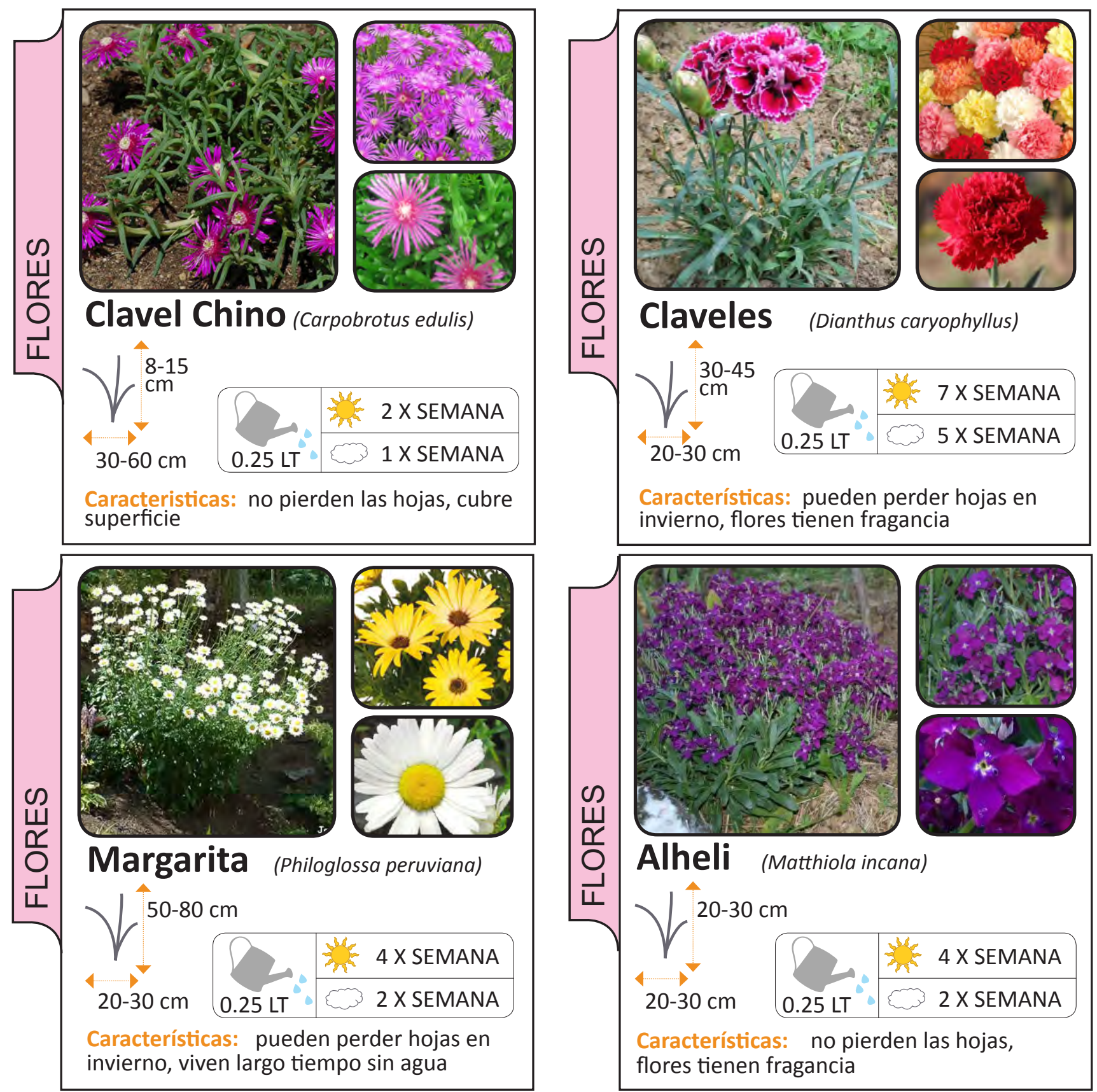

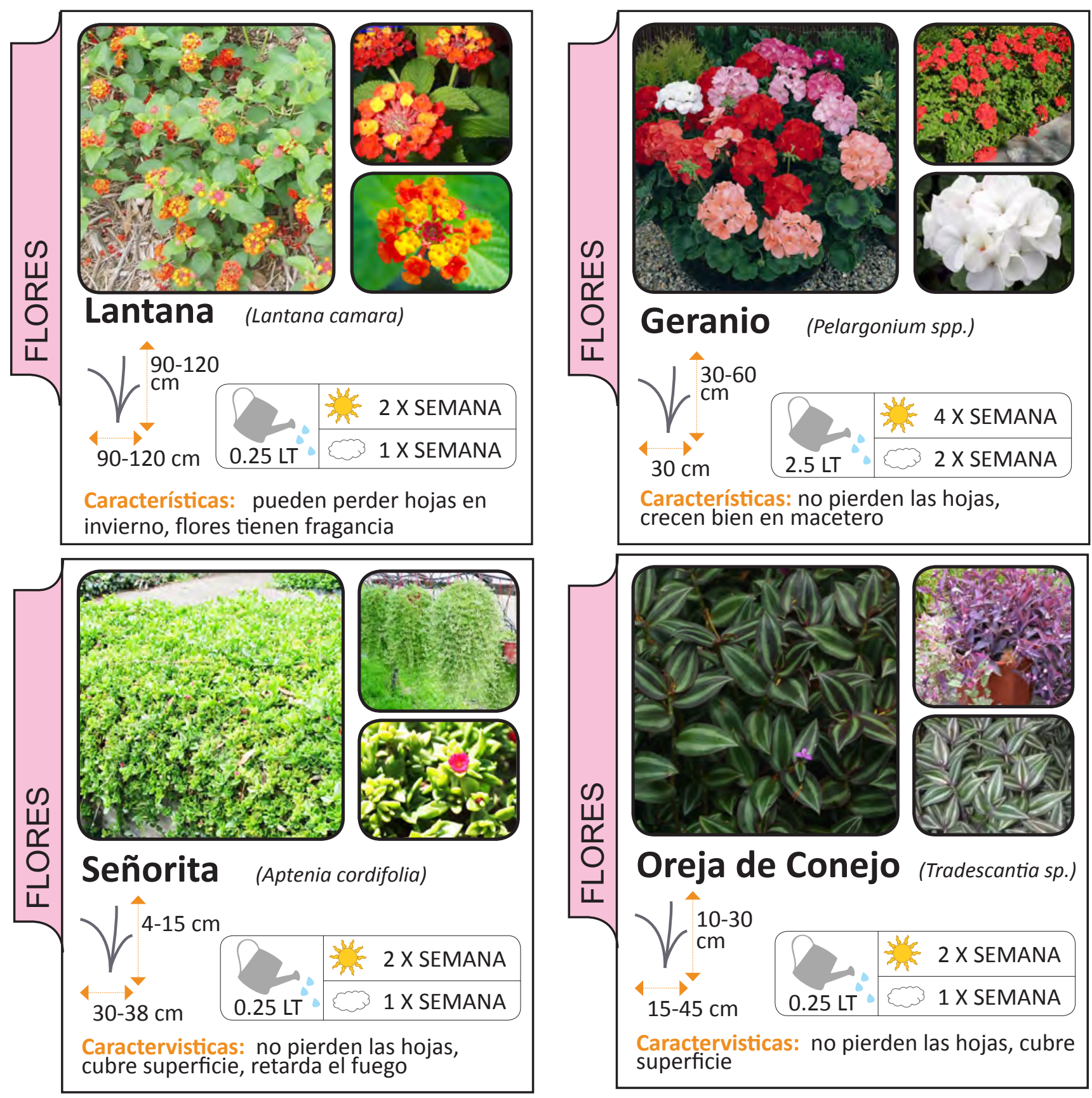

Caractervisticas: no pierden las hojas, cubre superficie
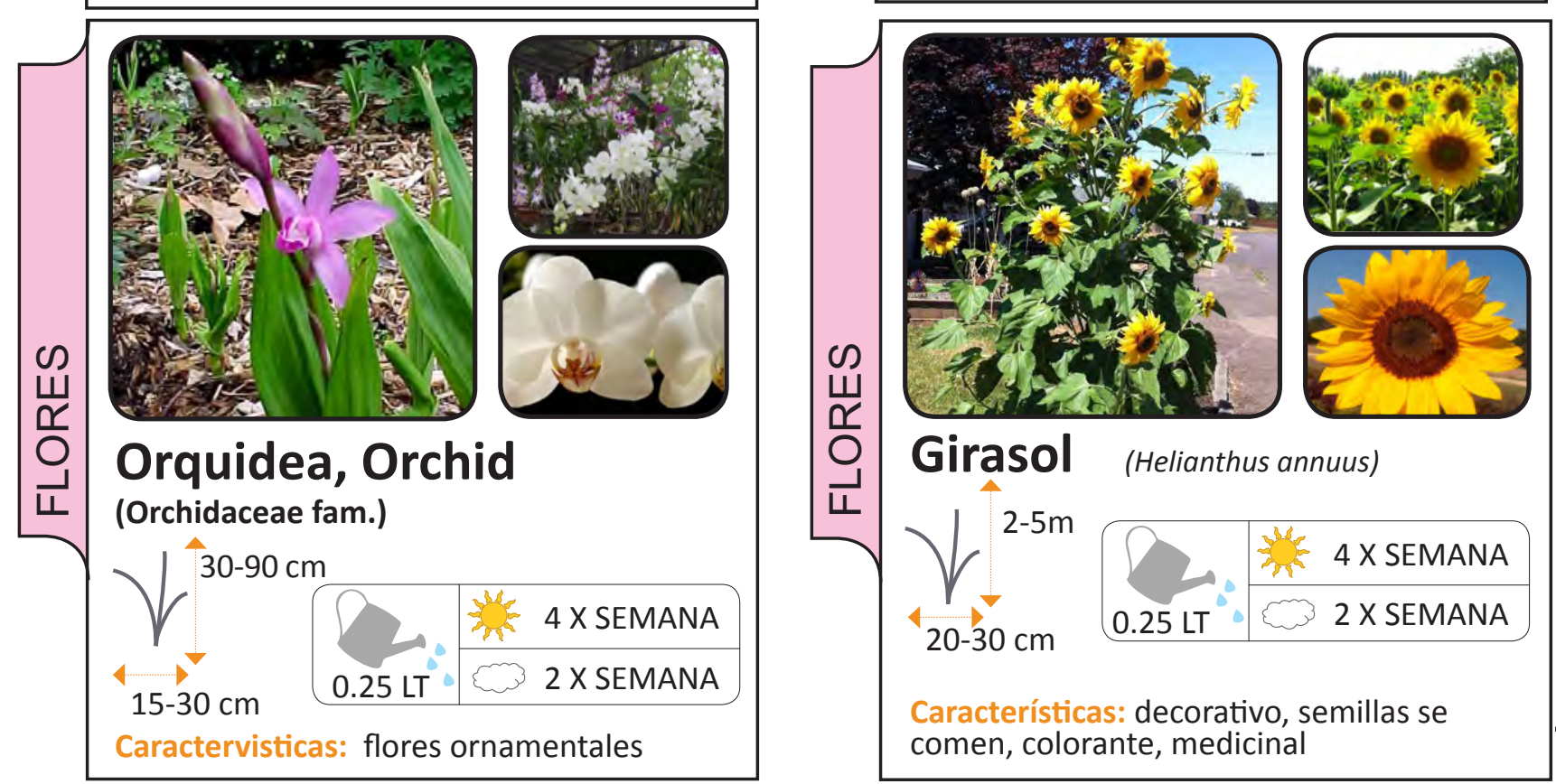

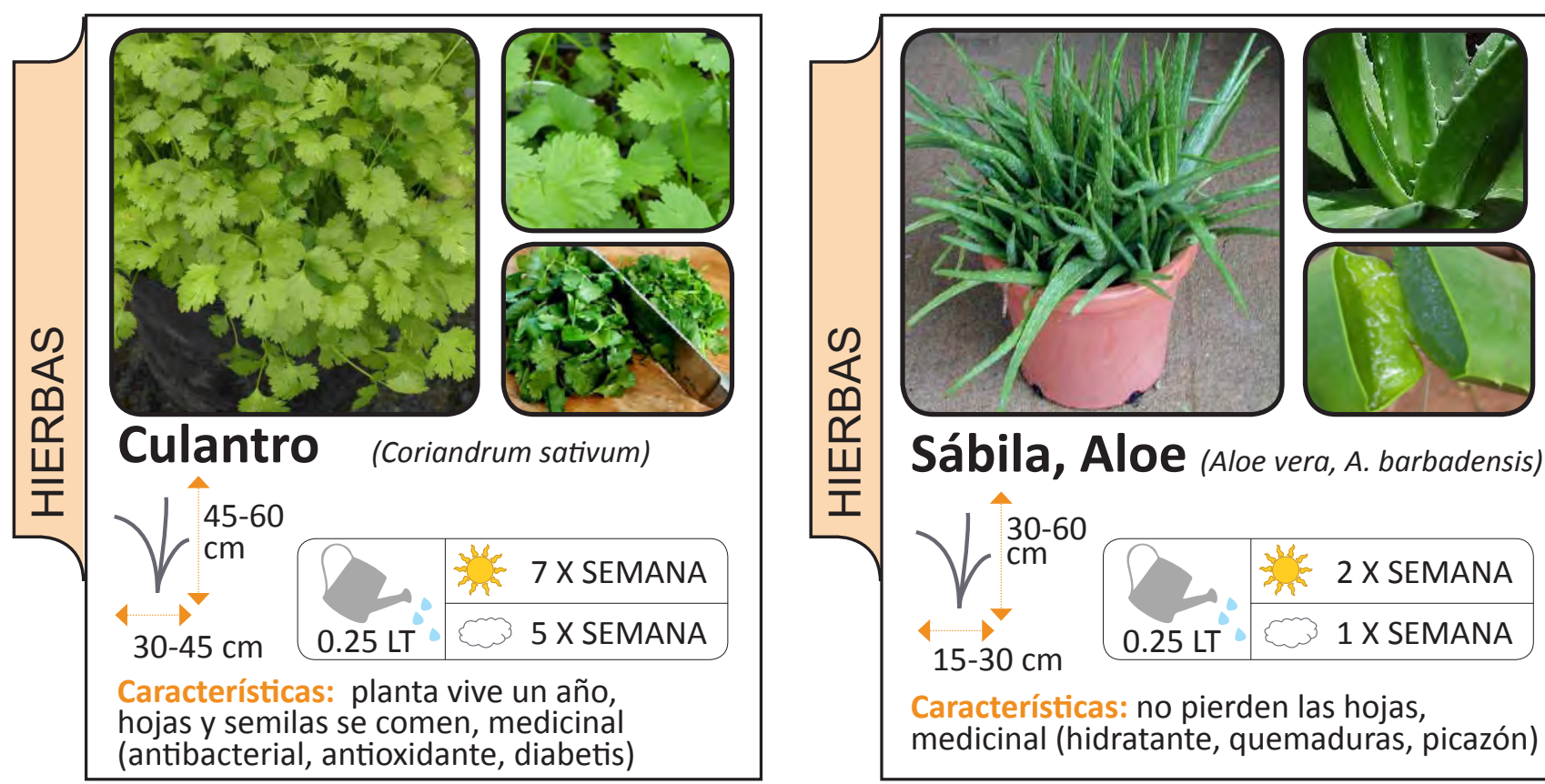

(antibacterial, antioxidante, diabetis)
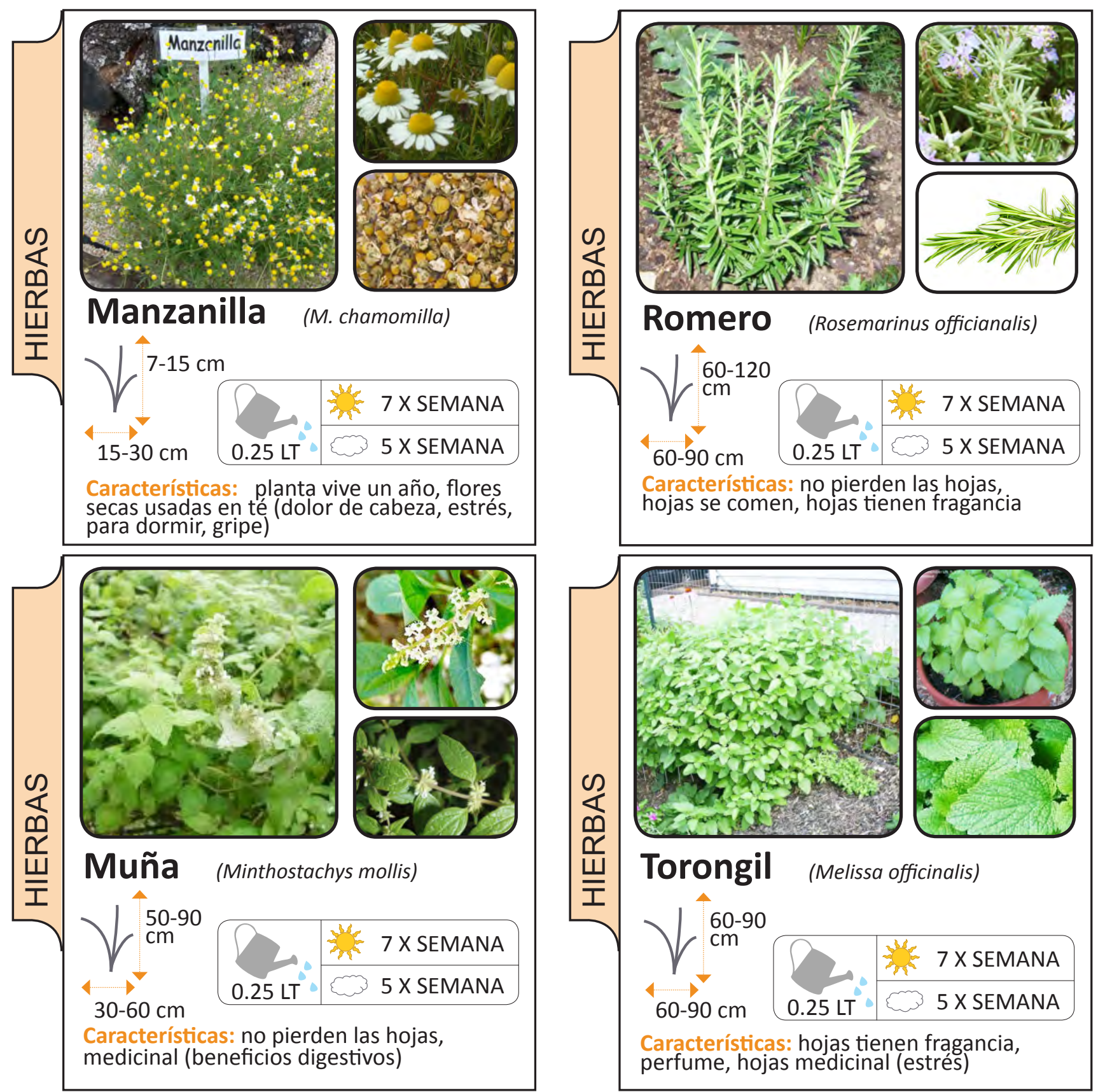

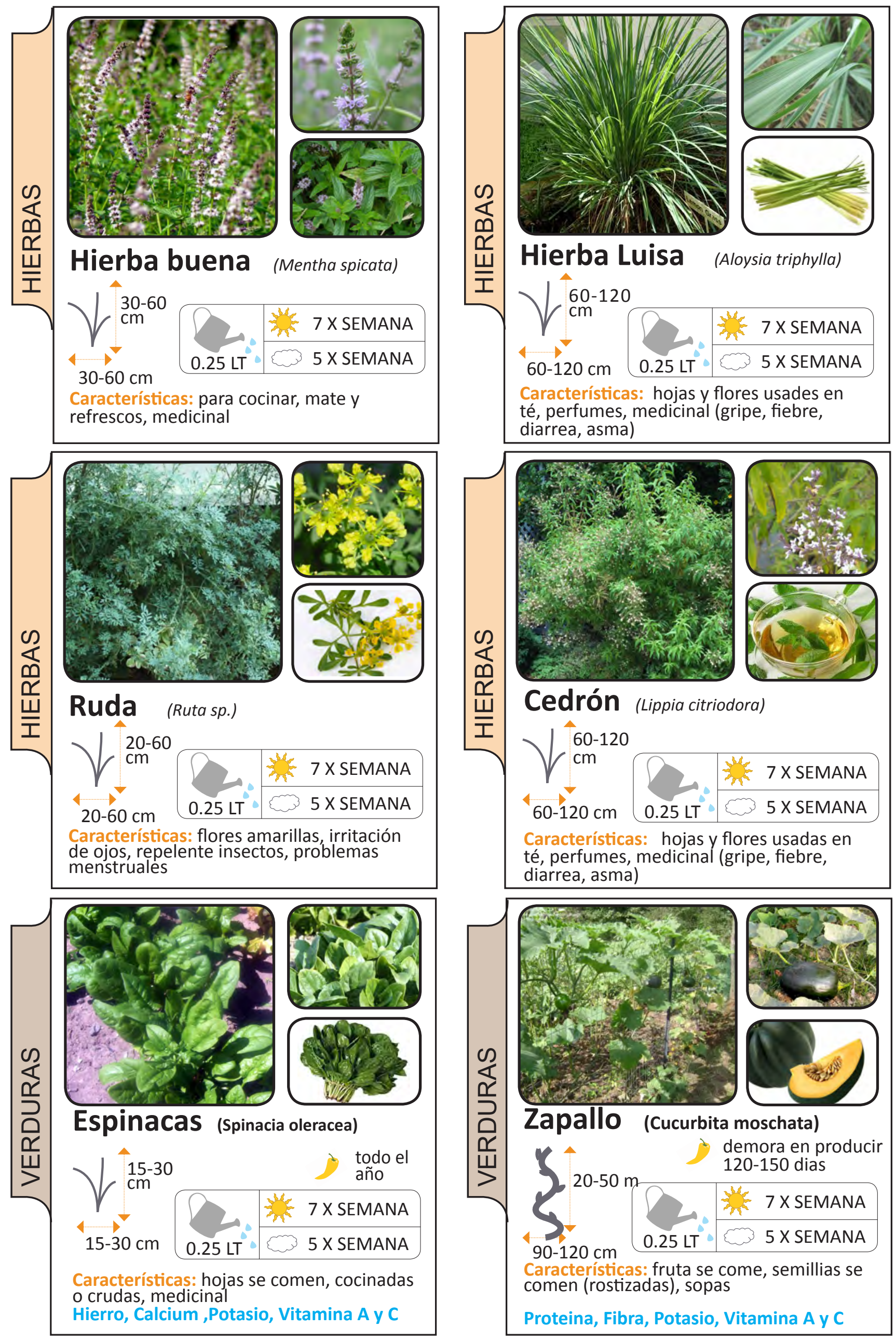

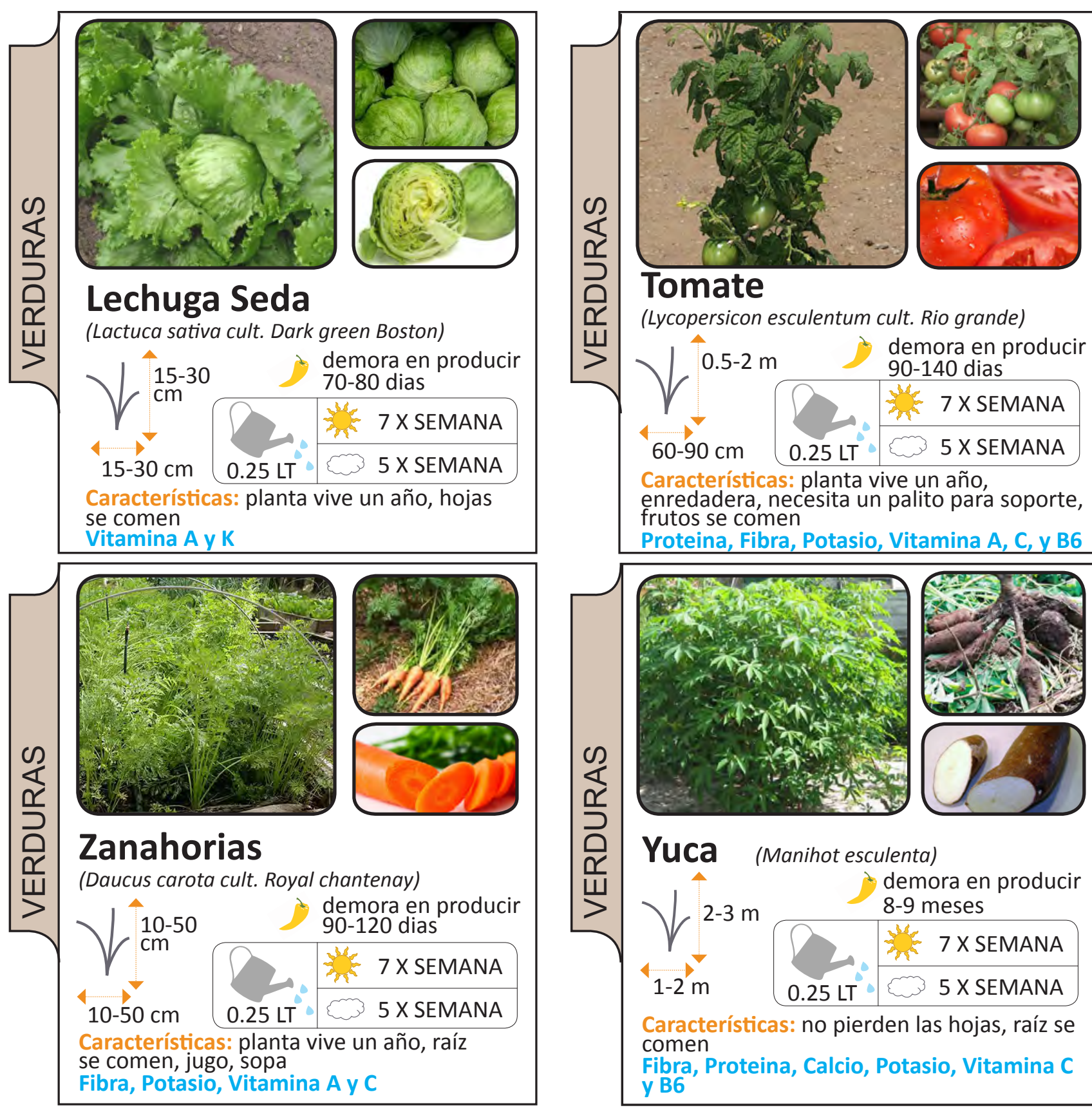

Características: planta vive un año, enredadera, necesita un palito para soporte, frutos se comen

Proteina, Fibra, Potasio, Vitamina A, C, y B6
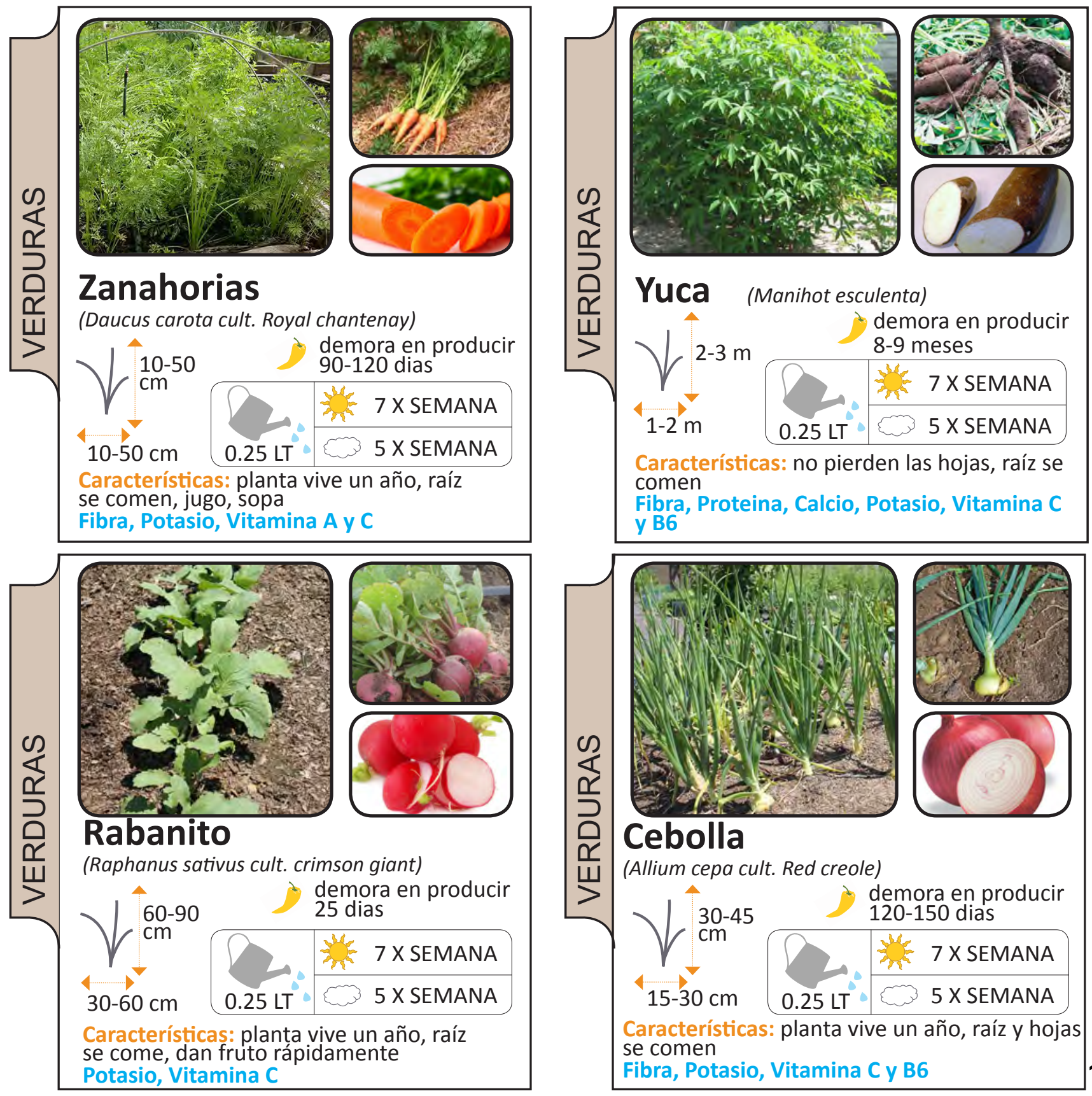

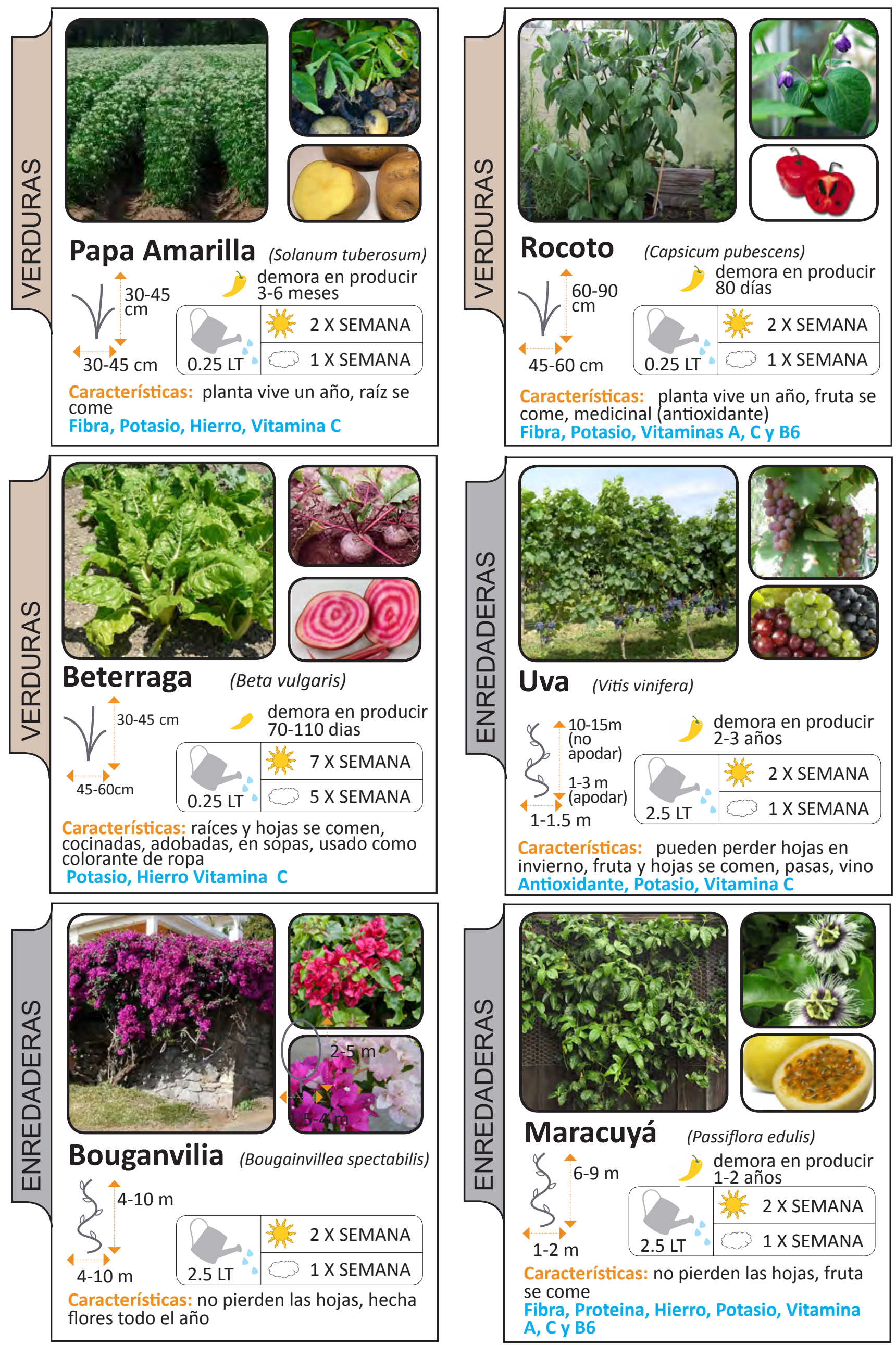


\section{¿Cómo mantener?}

\section{1. ¿Cómo hago para abonar las plantas?}

Cada cierto tiempo se tiene que abonar las plantas. Para abonar se hace un circulo de abono alrededor del tallo. No poner el abono directamente al tallo.

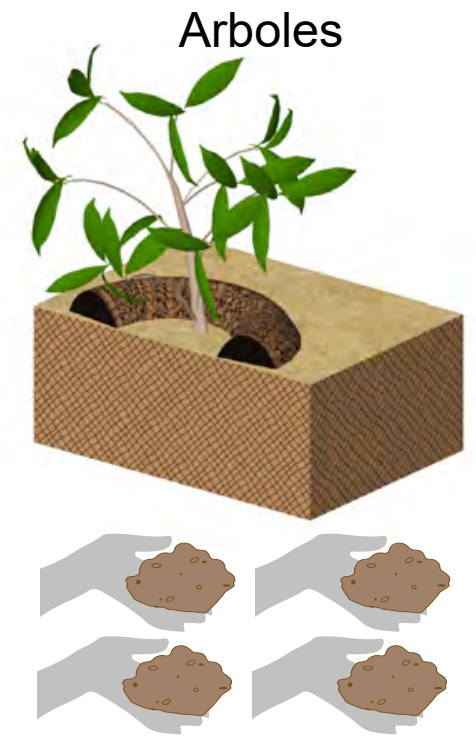

4 puñados de abono 1 vez al año
Arbustos
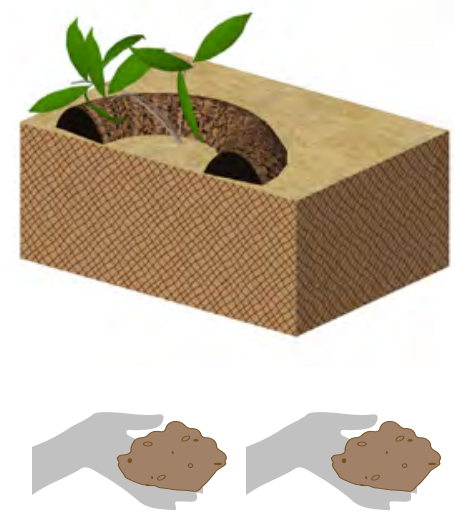

2 puñados de abono cada 6 meses
Plantas Pequeñas
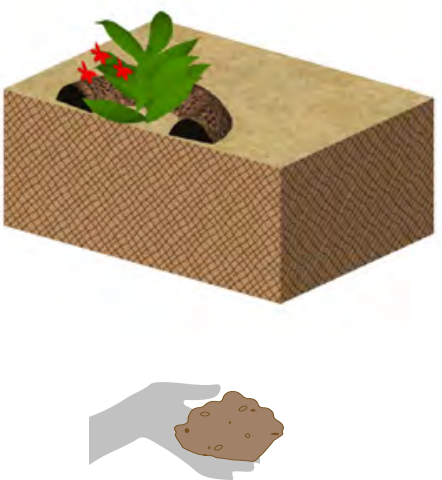

1 puñado de abono cada 6 meses

además para plantas que producen ...

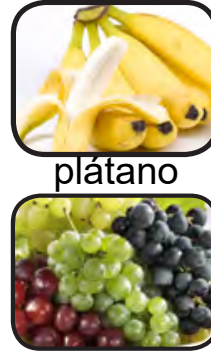

uva

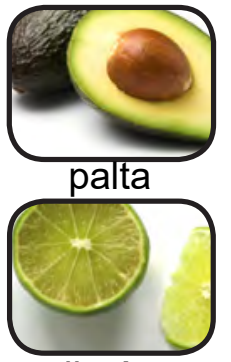

limón

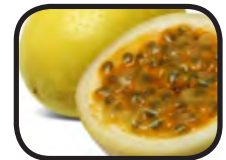

maracuyá

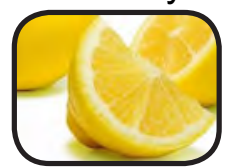

lima

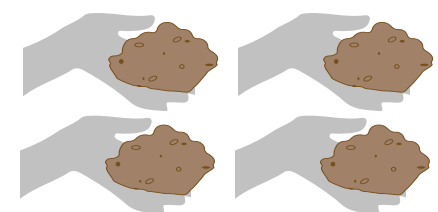

4 puñados de abono cada vez que se cosecha todos los frutos
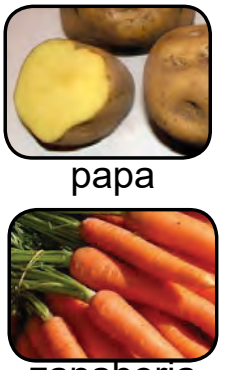

zanahoria

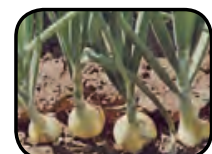

cebolla

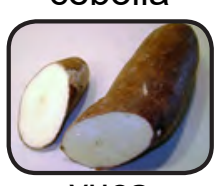

yuca

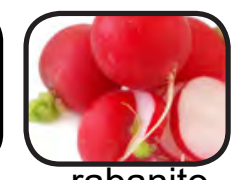

rabanito
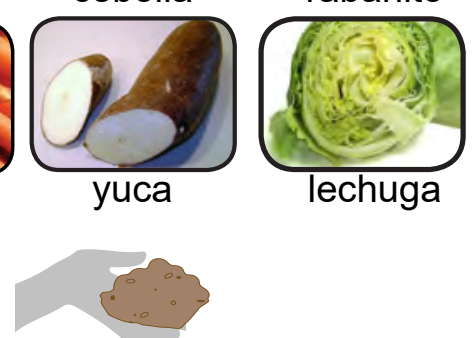

1 puñado de abono cada vez que se planta

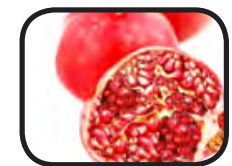

granada

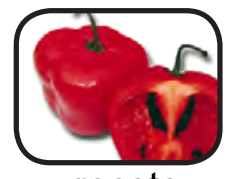

rocoto

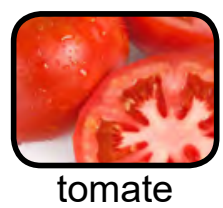

tomate

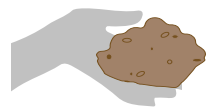

re?

2 puñados de abono cada vez que se cosecha todos los frutos 


\section{¿Cómo mantener?}

12. ¿Qué hacer cuando tenga plagas, gusanos, caracoles, pulgones blancos?

Siempre se debe revisar las plantas para ver si aparecen bichos. Si es posible retire con las manos. De lo contrario te damos algunas alternativas.
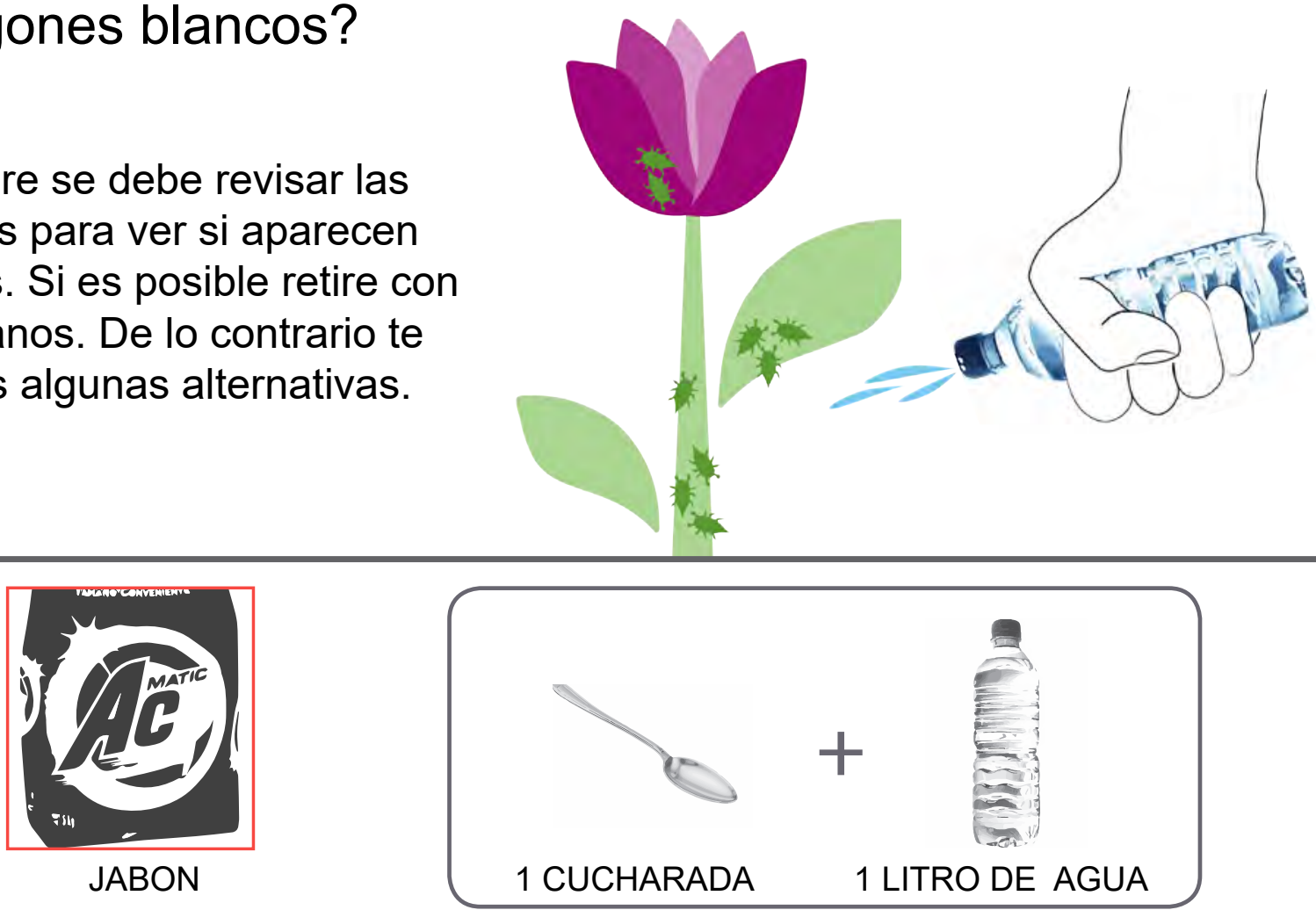

Puedes mezclar una cucharada de jabon (de preferencia los ecologicos) con un litro de agua y esparcir en las hojas, tallos y ramas para espantar a los insectos y plagas. NO USAR CLORO

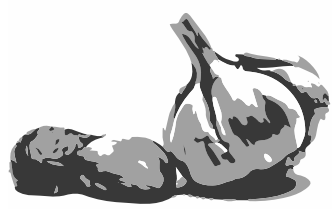

AJO

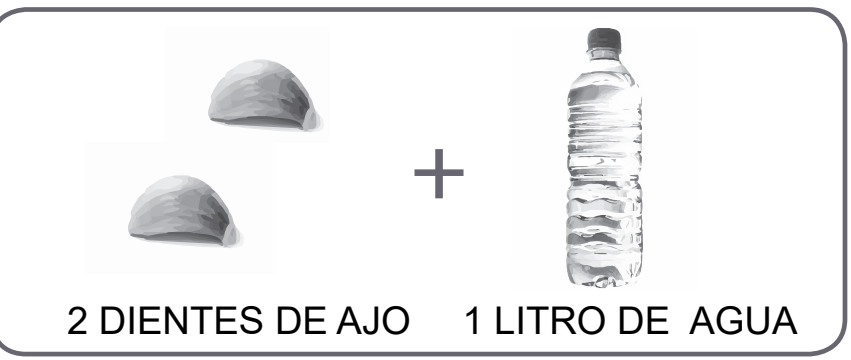

Puedes licuar dos dientes de ajo con un litro de agua y esparcir en las hojas, tallos y ramas para espantar a los insectos y plagas.
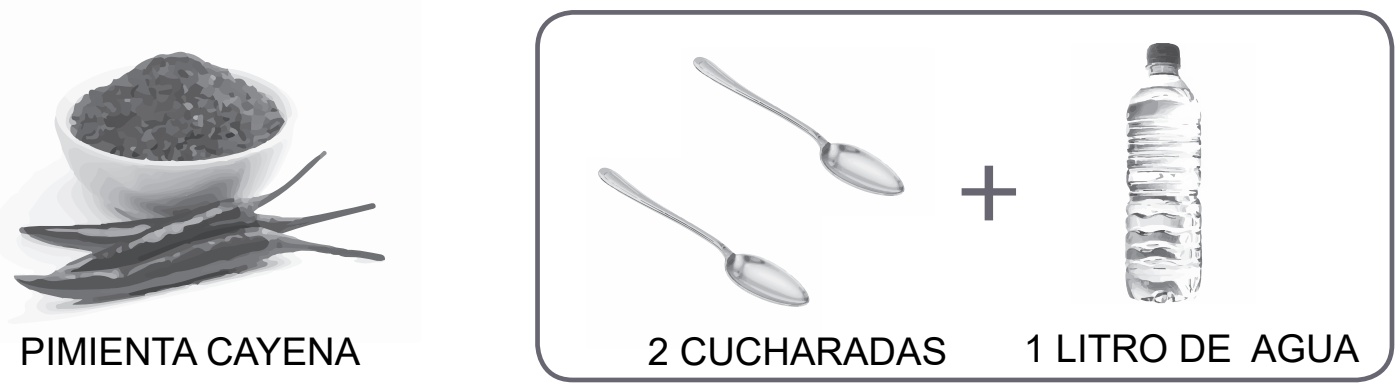

Puedes mezclar dos cucharadas grandes de pimienta cayena con un litro de agua y esparcir en las hojas, tallos y ramas para espantar a los insectos y plagas. 


\section{¿Cómo mantener?}

Que son pulgas blancas?

Pulgas blancas son un tipo de plagas que se pueden encontrar en los tallos y ramas, especialmente en las plantas como las rosas. Pueden crear una capa escamosa y blanca.

\section{¿Cómo eliminarlos?}

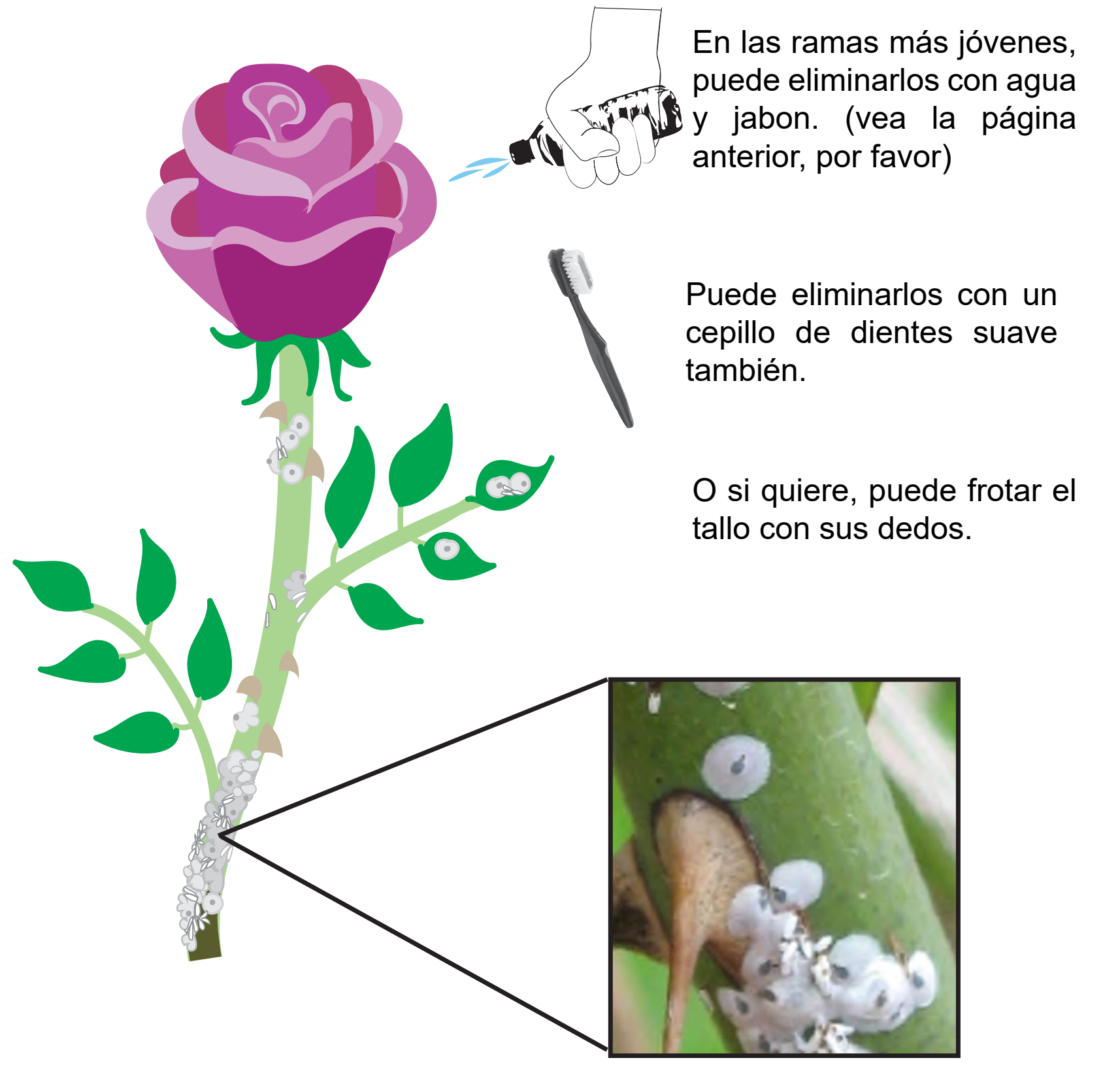

13. ¿Que hago con los pollos, perros y gatos?

Protege siempre tu jardín con un el cerco, repáralo si es necesario, no dejes huecos. Si tiene problemas con aves, ponga una malla horizontal encima de las plantas.

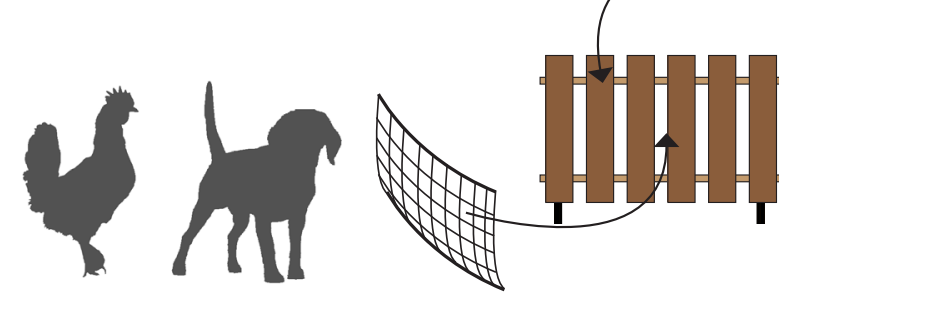




\section{4. ¿Cómo hacer una caja para compost?}

\section{OPCION A: EN UNA CAJA ENTERRADA}

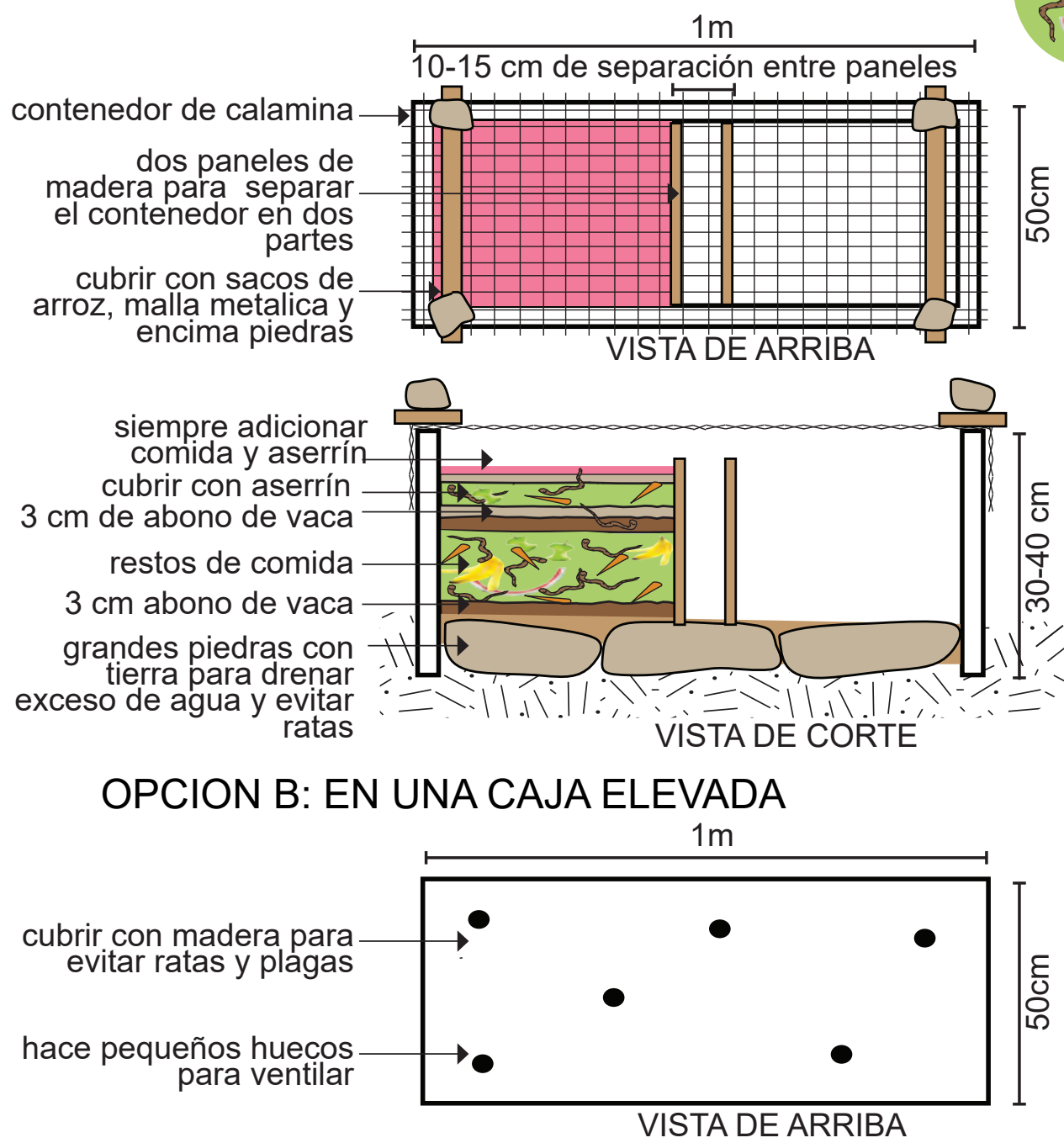

cubierta de madera siempre adicionar comida y aserrín

cubrir con aserrín

$3 \mathrm{~cm}$ abono de vaca

restos de comida

$3 \mathrm{~cm}$ abono de vaca hace pequeños huecos para ventilar

eleve la caja con piedra o ladrillos

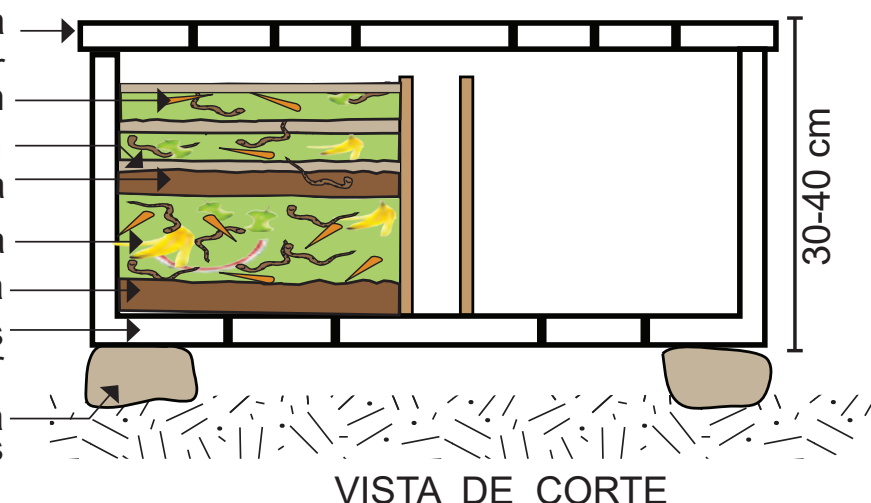

OPCIONAL: agregar lombrices hace que se produzca el compost más rápido.

1. Construir el contenedor ya sea opción A u opción B.

2. La primera vez que usas el contenedor poner una capa de abono de vaca. Esto ayuda a producir lombrices más rápido. Luego agrega comida y lombrices si gusta. Luego cubrir con otra capa de abono de vaca. Agregar una

El aserrín ayuda a reducir los olores.

3. Agregar comida cada vez que uno quiera, y un poco de aserrín si es necesario. No volver a agregar abono de vaca.

4. Agregar un litro de agua interdiario en invierno y diario en verano.

5. Siempre cubrir las cajas para que no caiga sol y no entren moscas o ratas.

6. Su compost estará listo en 3 o 4 meses.

Cuando toda la comida desaparezca, comience a llenar el otro depósito. Levante la división para que las lombrices pasen de un lado a otro.

\section{5. ¿Cómo mantener el compost?}

A Agregue un litro de agua interdiario.
B Cubra su caja de compost y eleve con rocas, o selle el fondo para evitar ratas, moscas $u$ otras plagas.
C Cuando el primer lado esta lleno, empiece a llenar el segundo. Levante el separador y deje un espacio para que pasen las lombrices de un lado a otro.
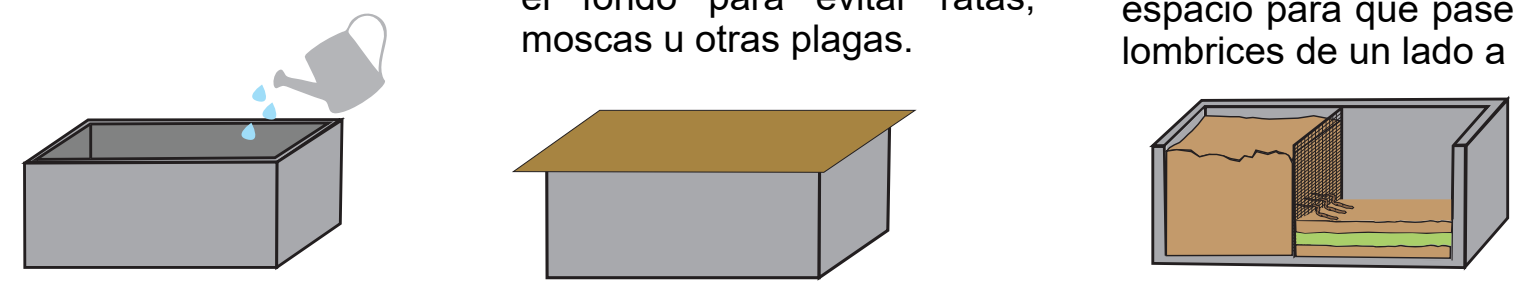
16. ¿Qué puedo compostar?

SI
USAR

cáscara de huevo

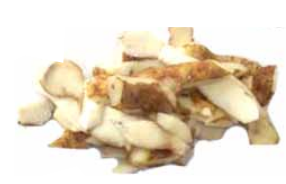

restos de comida

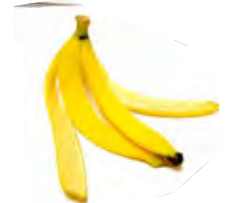

cáscara de frutas

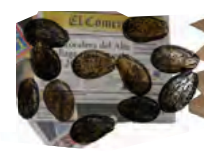

semillas

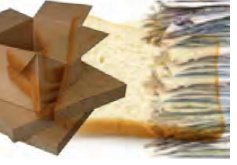

pan

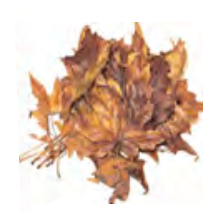

plantas
NO
USAR

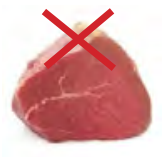

carne

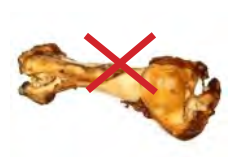

huesos

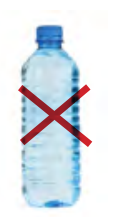

plásticos metales

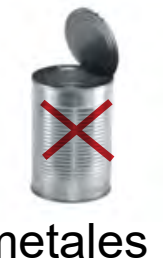

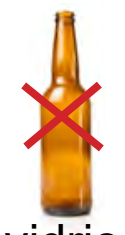

vidrio

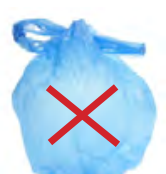

bolsas de excremento plástico

\section{7. ¿Qué debo tomar en cuenta?}

El compost mejora la tierra y hace crecer mejor a las plantas.

Producir compost recicla residuos y basura biodegradable.

Producir compost ahora dinero porque ya no tienes que comprar abono.

Si esta bien hecha el compost, no debe tener olor.

Siempre mantener a los niños y mascotas alejado del envase de compost.

No todo puede compostarse, tomar en cuenta esto para evitar plagas o enfermedades.

\section{8. ¿Cómo solucionar un problema con mi compost?}

\begin{tabular}{|c|c|c|}
\hline $\begin{array}{l}\text { PROBLEMA } \\
\text { huele mal }\end{array}$ & $\begin{array}{l}\text { CAUSA } \\
\text { muy humedo, hay } \\
\text { carne, lácteos o } \\
\text { heces }\end{array}$ & $\begin{array}{l}\text { SOLUCION } \\
\text { cubrir con aserrín, no } \\
\text { echar carne, lácteos ni } \\
\text { heces, tapar el recipient }\end{array}$ \\
\hline $\begin{array}{l}\text { muy seco, } \\
\text { pocos } \\
\text { gusanos }\end{array}$ & agua & $\begin{array}{l}\text { agregar agua y proteger } \\
\text { del sol }\end{array}$ \\
\hline $\begin{array}{l}\text { aparecen } \\
\text { larvas de } \\
\text { moscas }\end{array}$ & $\begin{array}{l}\text { hay carne, lácteos } \\
\text { heces }\end{array}$ & $\begin{array}{l}\text { no echar carne, lácteos } \\
\text { heces, tapar el recipient }\end{array}$ \\
\hline $\begin{array}{l}\text { mosca de } \\
\text { frutas }\end{array}$ & compost expues & $\begin{array}{l}\text { Cubrir con cartón, saco } \\
\text { de arroz, aserrín }\end{array}$ \\
\hline
\end{tabular}




\section{Guía de compras} ANILLO RECTANGULAR Y CIRCULAR DE CONCRETO (MACETA)

$70 \times 40 \times 30 \mathrm{~cm}, 10.00 \mathrm{~S} / .-12.00 \mathrm{~S} /$.

40 dia. $\times 30 \mathrm{~cm}, 7.00 \mathrm{~S} /$.

Grupo Hard S.A.C.

Calle Las Cascadas Mz D. Lote 51

Asoc. Leoncia Prado Oeste

Puente Piedra- Lima

Telf: $550-2298$

Covipre

551-0967

Comas

Planta La Ensenada

Lotización Chillón Pte Piedra Mz.b Lt.1

\section{VARIEDAD DE MACETAS Y ANILLOS DE CONCRETO}

Maestro

Puente Piedra

Altura Kilómetro 30 Panamericana Norte

Cruce de Av. San Juan de Dios con Calle 7

San Martín de Porres

Av. Alfredo Mendiola 7026

\section{LOSETA DE CONCRETO}

$30 \times 30 \mathrm{~cm}, 3.00 \mathrm{~S} /$.

Covipre

551-0967

Comas

Planta La Ensenada

Lotización Chillón Pte Piedra Mz.b Lt.1

\section{RED}

$5.00 \mathrm{~S} /$. por $8 \mathrm{~m}$

Venta de Cabos en General

Ancón

Av. Parades, Mercado Ancón Puesto 8 CERCOS, CEMENTO, PIEDRA

Se pueden mandar a hacer los cercos, bancas y enredaderas en la carpinteria local.

Se puede comprar cemento y arena en las ferreterias locales

La piedra se puede conseguir localmente
ARBOLES, PLANTAS, ARBUSTOS

$2.50-12.00 \mathrm{~S} /$.

Vivero "MAXIMO"

AA. HH. Cesar Vallejo Mz.

B Lote 2 Zapallal, Pte. Piedra

Telf: 784-7950 / 771789999

For Prodes

525-0859

Comas

Av. Estados Unidos 327 Urb. Huaquillay

\section{VERDURAS SEMILLAS}

$$
3.00-4.00 \mathrm{~S} / .
$$

Comercial Agrícola Progreso S.A.C.

574-5456

Carabayllo

Kilómetro 22

Av. Túpac Amaru 3490, El Progreso

ARS Agris S.R.L.

547-0124

Carabayllo

Kilómetro 22

Av. Túpac Amaru 3490, El Progreso

Promart

San Martín de Porres

Real Plaza, Av. Alfredo Mendiola N 7026

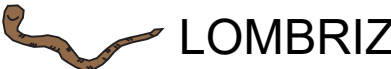

Sra. Soledad Agreda

971-364-994

Puente Piedra

Mz L1 lote 33 Lomas de Zapallal

Universidad Agraria de la Molina

349-5933

La Molina

Av. La Molina s/n- La Molina

Guias/ Manuales

www.manualdelombricultura.com/curso/ www.hechoxnosotrosmismos.com/t3165-

manual-de-lombricultura

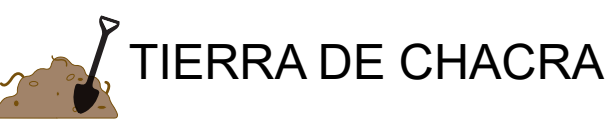

For Prodes

$12.00 \mathrm{~S} /$. por bolsa

525-0859

Comas

Av. Estados Unidos 327 Urb. Huaquillay 
Construction and Maintenance Manuals

Appendix 5: Fog Collectors Maintenance Manual 


\section{ATRAPANIEBLAS: MANUAL DE CONSTRUCCION}

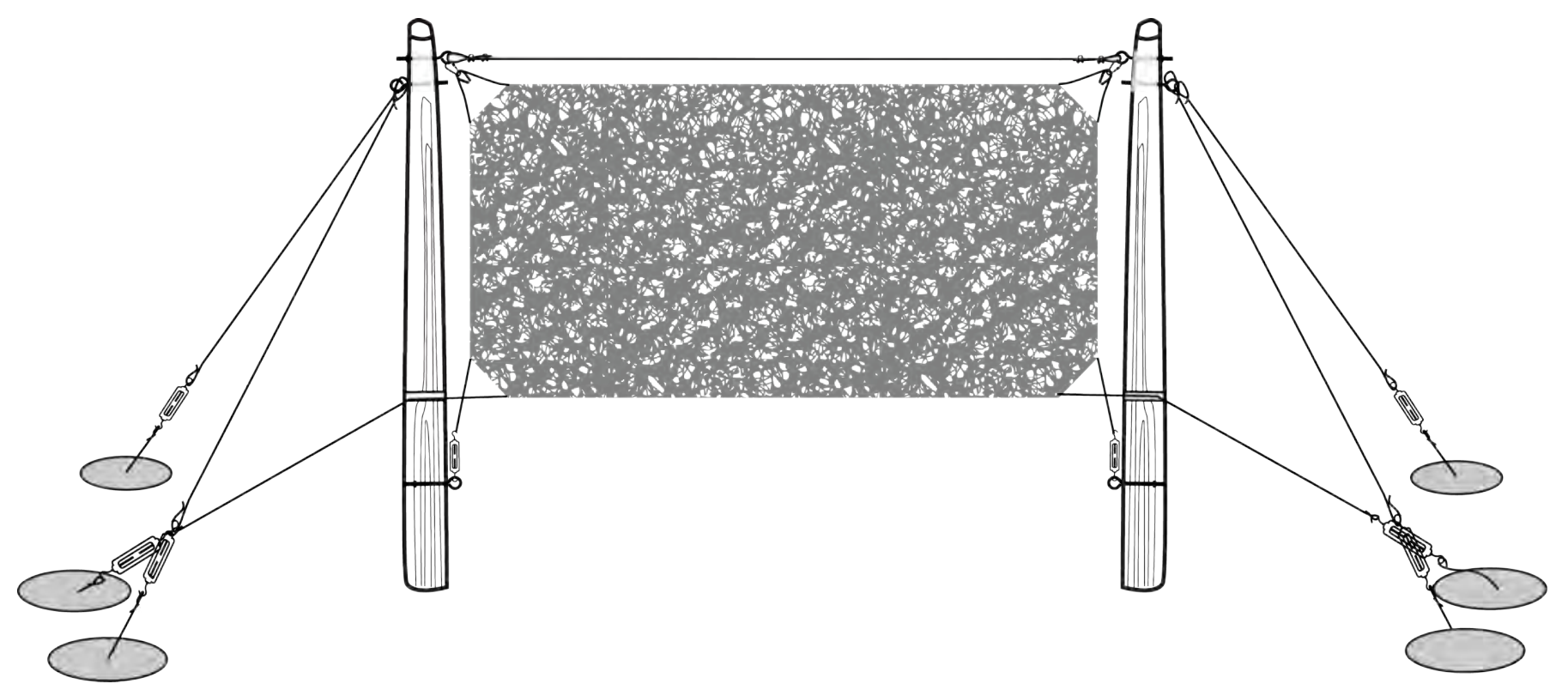




\section{HERRAMIENTAS REQUERIDOS}

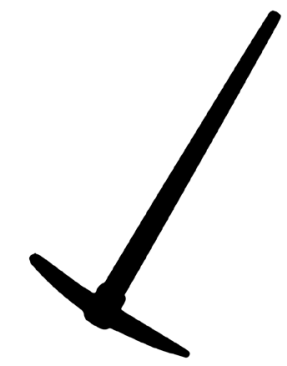

Pico

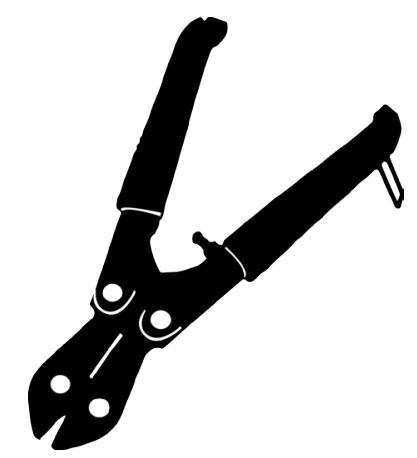

Cortacable

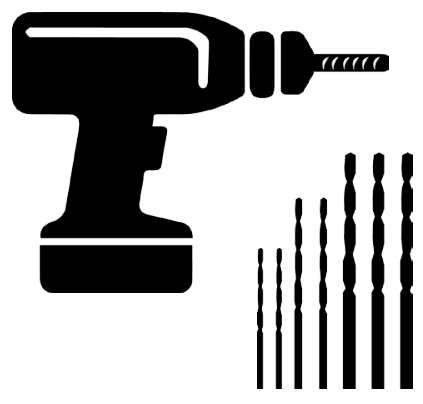

Taladro e brocas

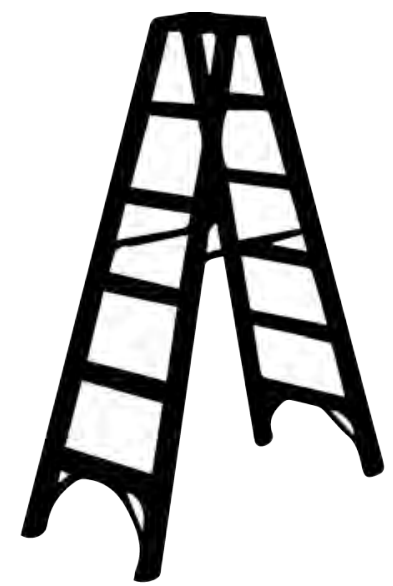

Escalera min. $6 \mathrm{~m}$

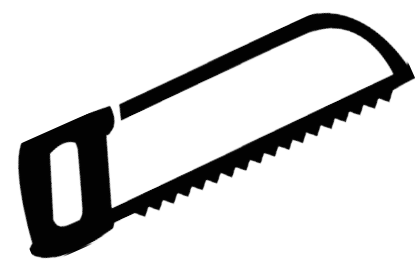

Serrucho

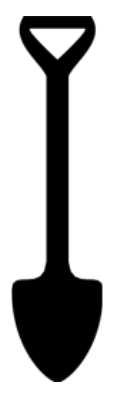

Lampa

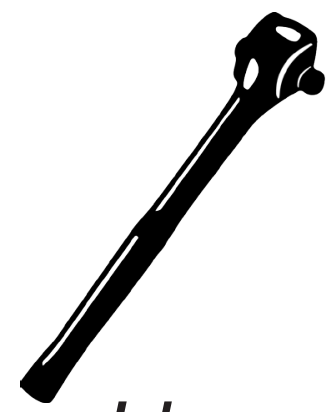

Llave

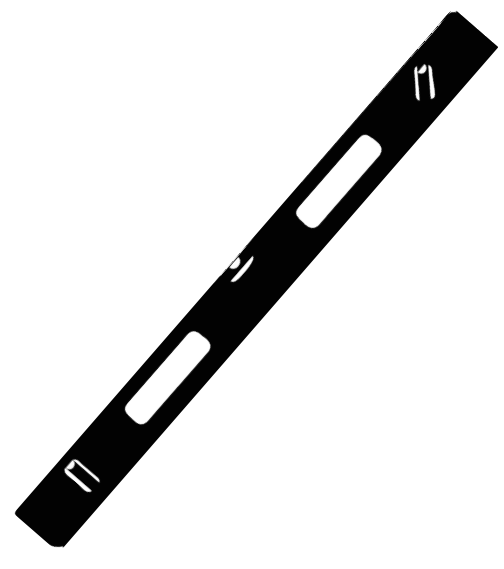

Nivel

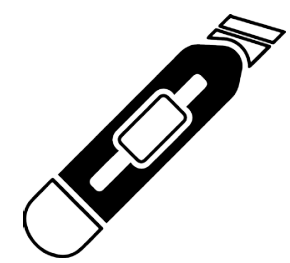

Cuchilla

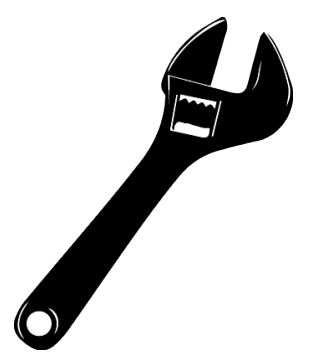

Llave Inglesa
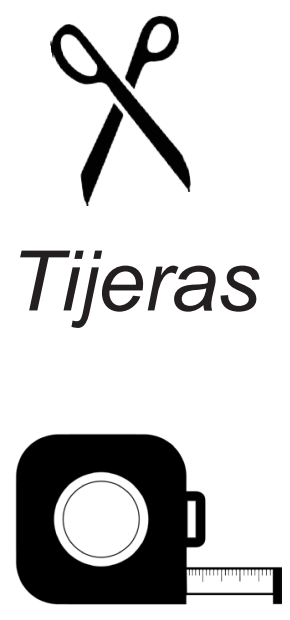

Wincha 3 a $5 \mathrm{~m}$

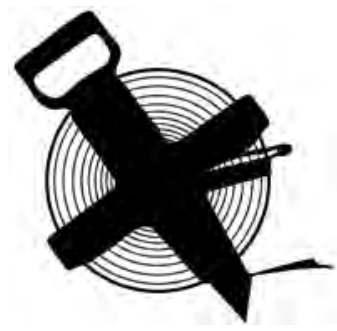

Wincha 50 metros 


\section{MATERIALES REQUERIDOS}

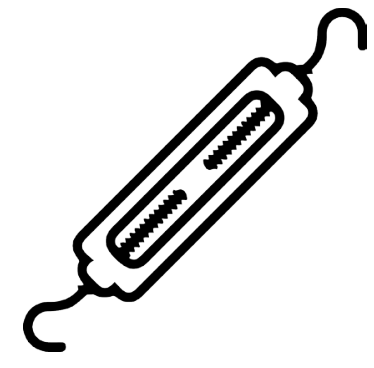

tensores

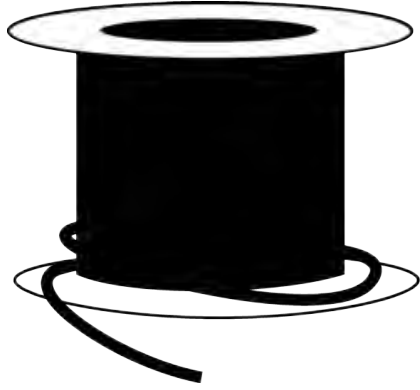

cable

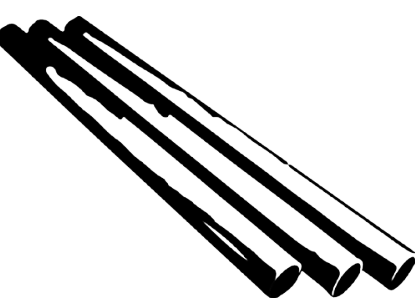

Tubo PVC

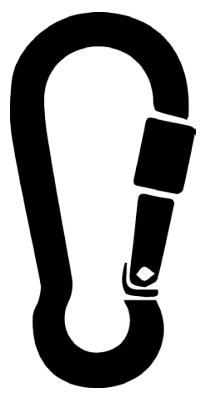

mosquetónes
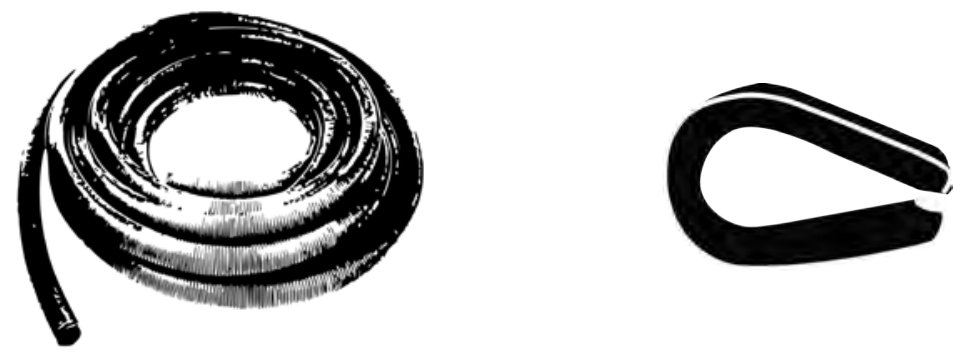

envoltura

hose/manguera

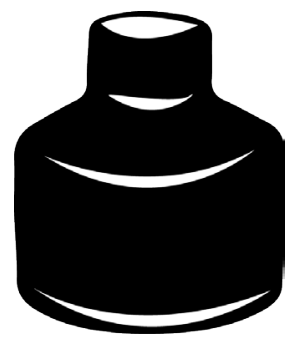

Accessorio para PVC

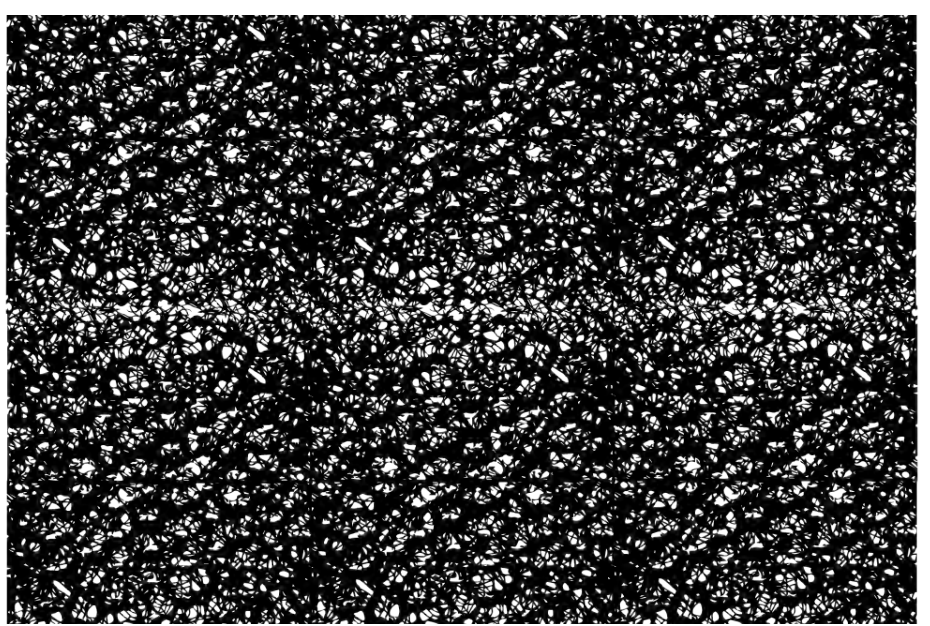

Malla

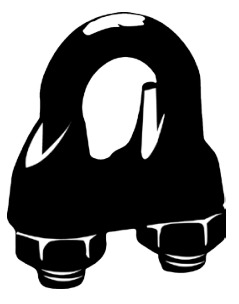

grapa

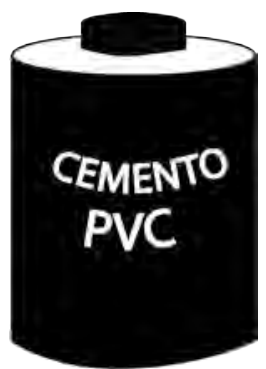

PVC armella

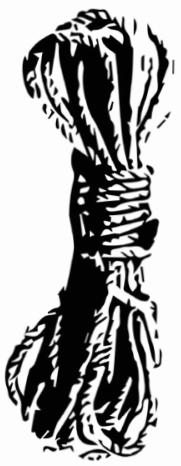

de cuerda lasso

Cemento de

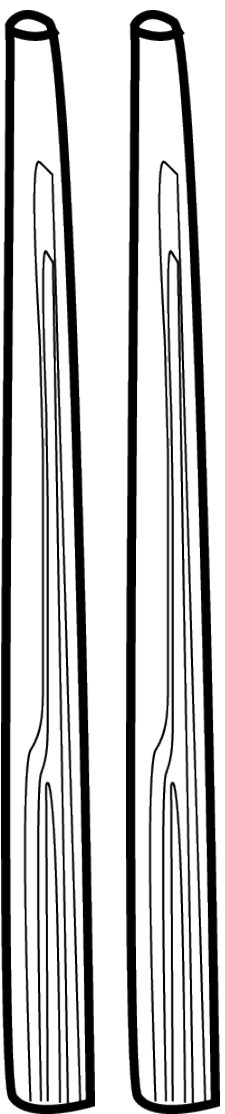

de plástico 


\section{Preparación del Sitio}

Limpiar el area y alrededores de obstrucciones

Cavar hoyos para los postes y hoyos para las anclas

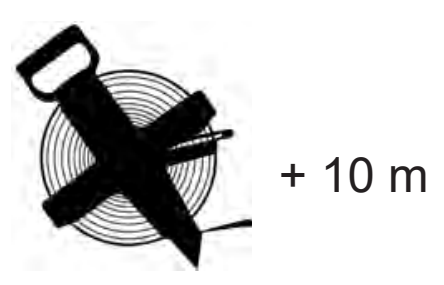

Hoyos de los Postes (x 2): $15 \mathrm{~cm}$ de profundidad Hoyos para los Anclas (x 6): $1 \mathrm{~m}$ de profundidad
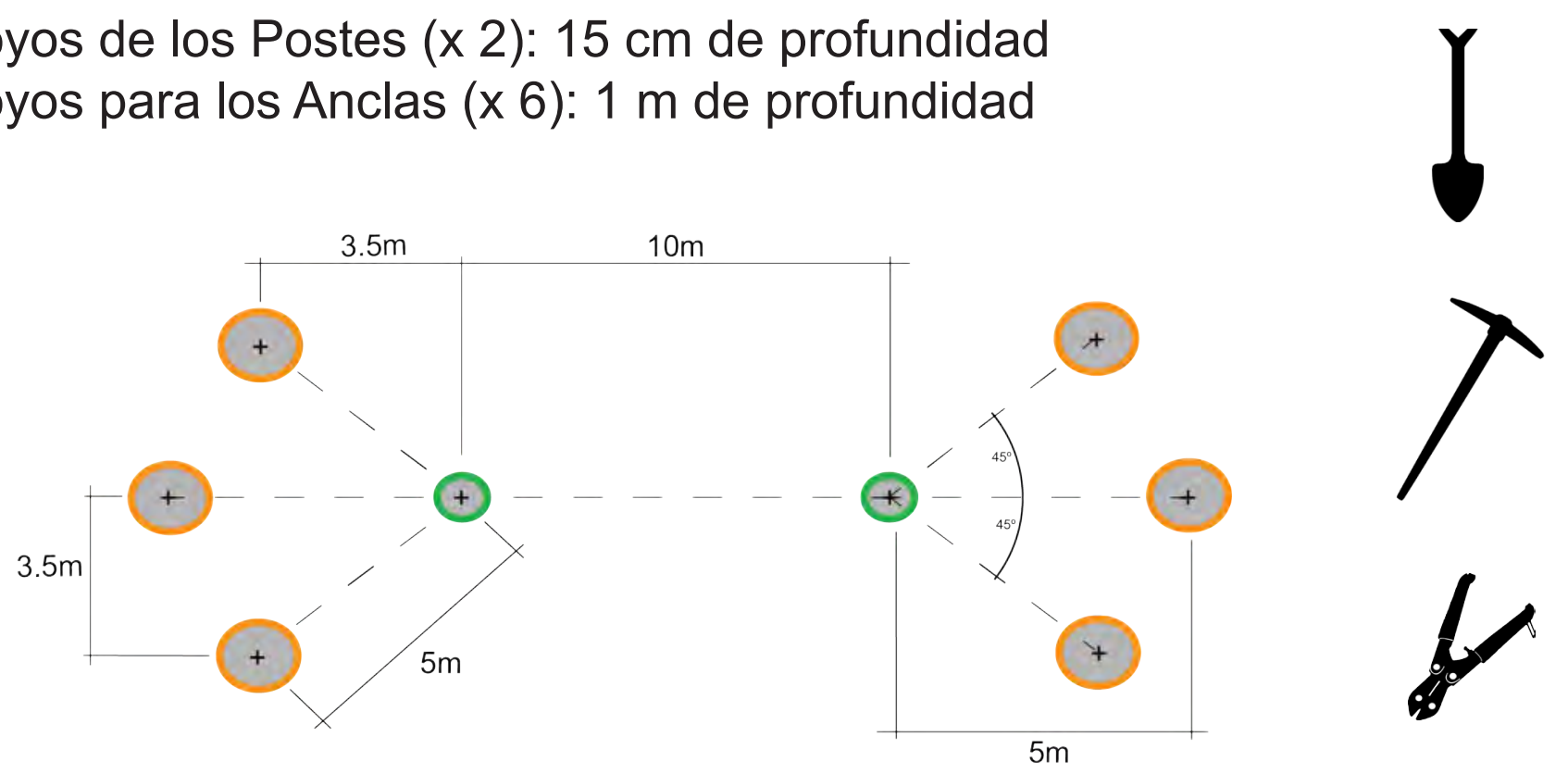

$15 \mathrm{~cm}$ de profundidad

$+\quad 1 \mathrm{~m}$ de profundidad
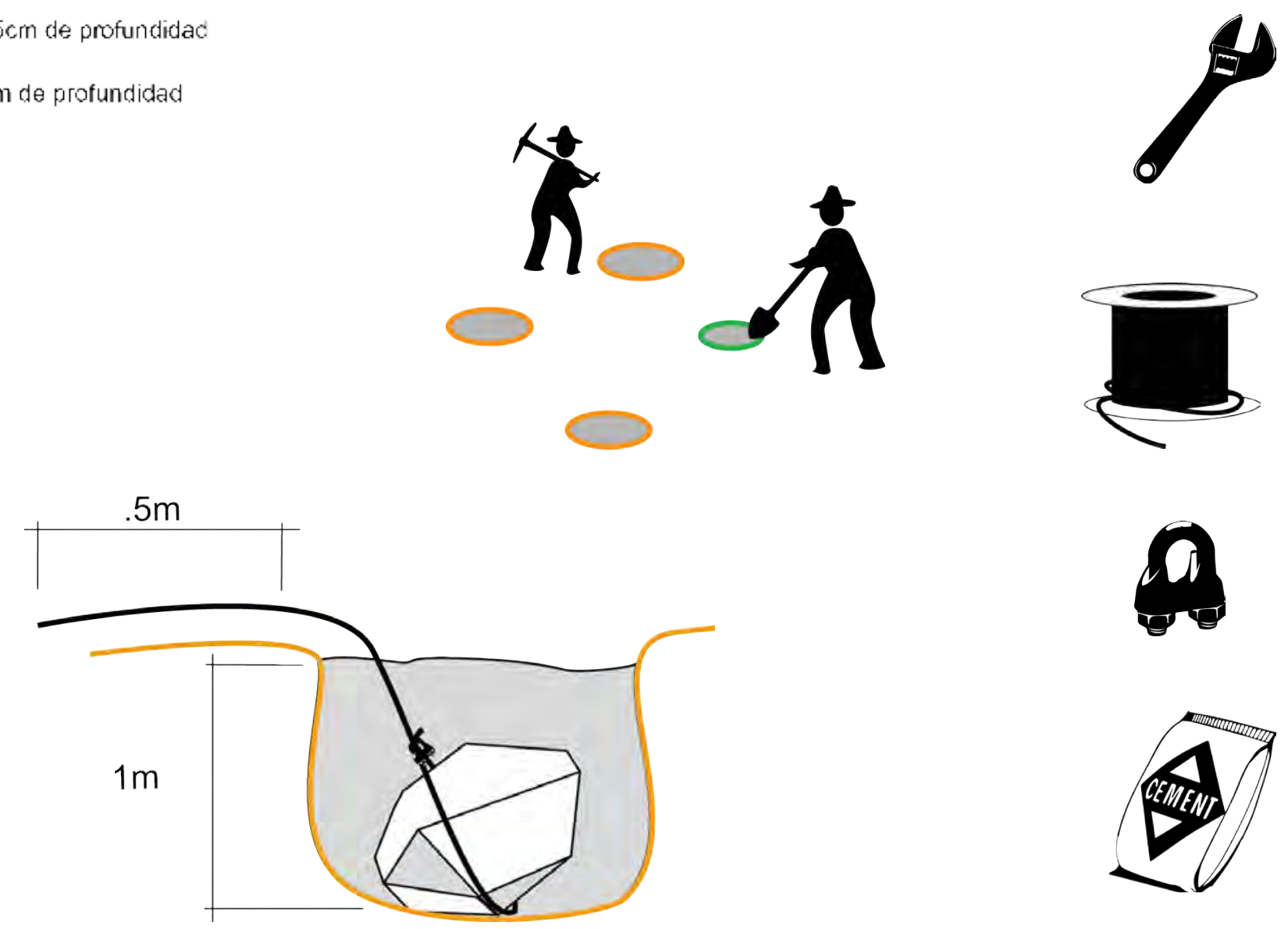

$12 \mathrm{~m}$
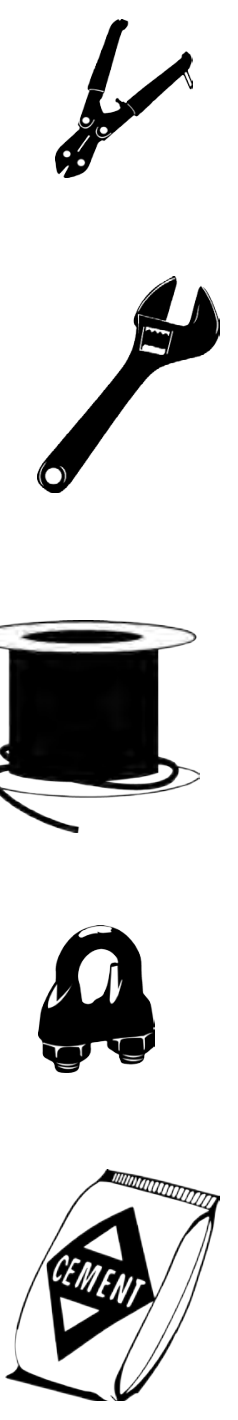

$x 12$ 


\section{Poste}

Largo de Poste: $6.5 \mathrm{~m}$.

Diametro del Poste $\sim 20 \mathrm{~cm}$ en la base, $12 \mathrm{~cm}$ en la parte superior

Mide $10 \mathrm{~cm}$ de la parte superior del poste y haz un agujero con el taladro instalando la armella en la area interior del poste.

Mide $5 \mathrm{~cm}$ de bajo del hoyo superior haz un segundo agujero con el taladro e instala otra armella en la area externa del

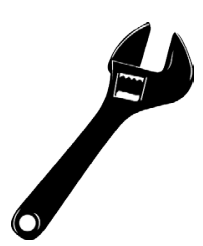
poste.

Mide $5.6 \mathrm{~m}$ desde la area superior del poste y haz un agujero con el taladro adicionando otra armella en el interior del poste.

Mide $4.2 \mathrm{~m}$ desde la area superior del poste y haz otro agujero con el taladro, este agujero sera en la area interior hasta la area exterior. Minimo, una broca de $8 \mathrm{~mm}$.
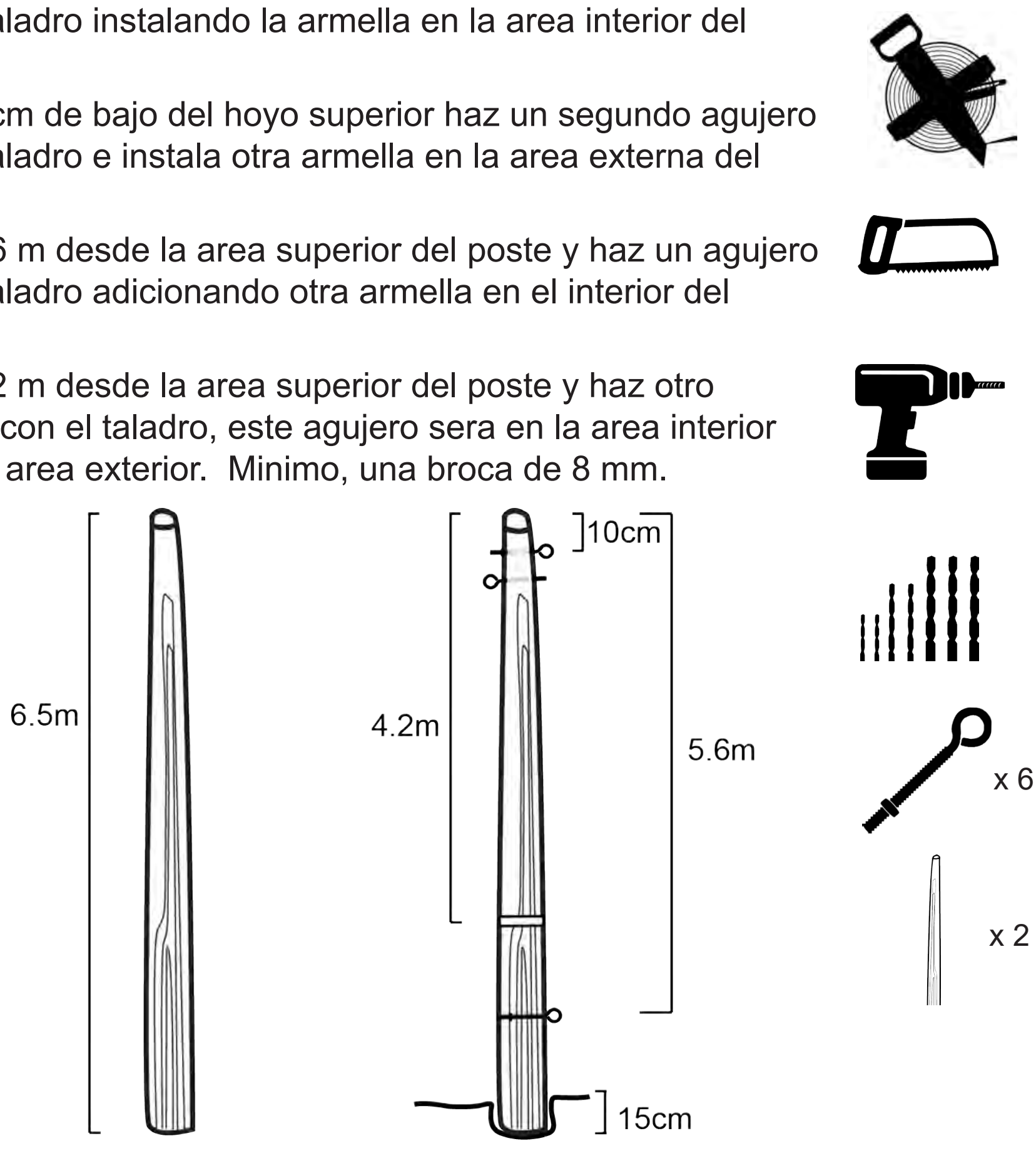

$x 2$ 


\section{Preparacion de la Malla}

Corta la malla: 1 malla de $8 \mathrm{~m} \times 10 \mathrm{~m}$

Corta la manguera: 2 pedazos de $9.8 \mathrm{~m}$

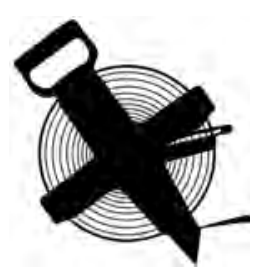

2 pedazos de $3.8 \mathrm{~m}$

Dobla la malla sobre una manguera de $10 \mathrm{~m}$ para obtener $4 \mathrm{~m} \times 10 \mathrm{~m}$

Cosa la malla a la manguera

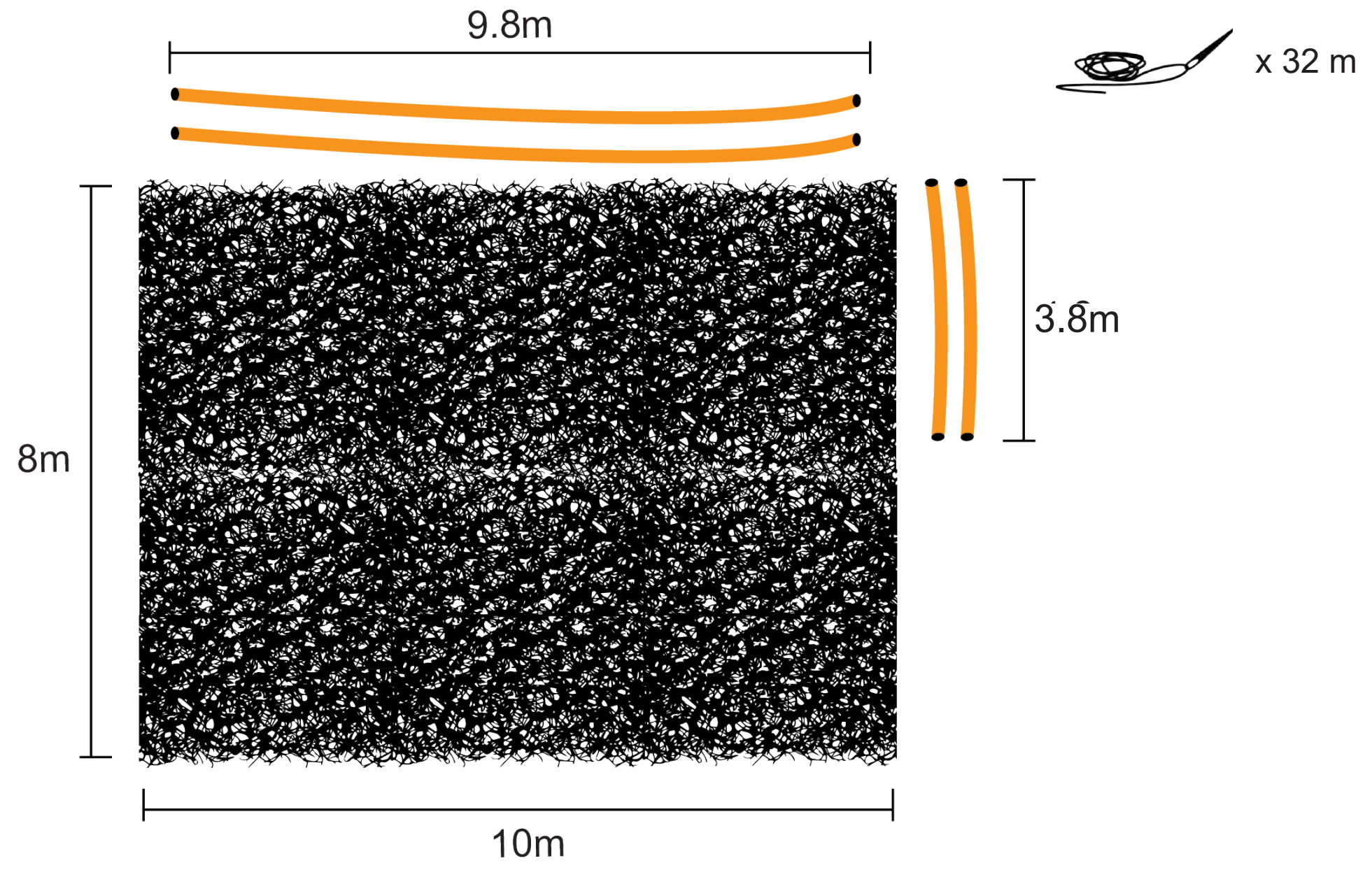

\section{Este trabajo se puede completar fuera del sitio}



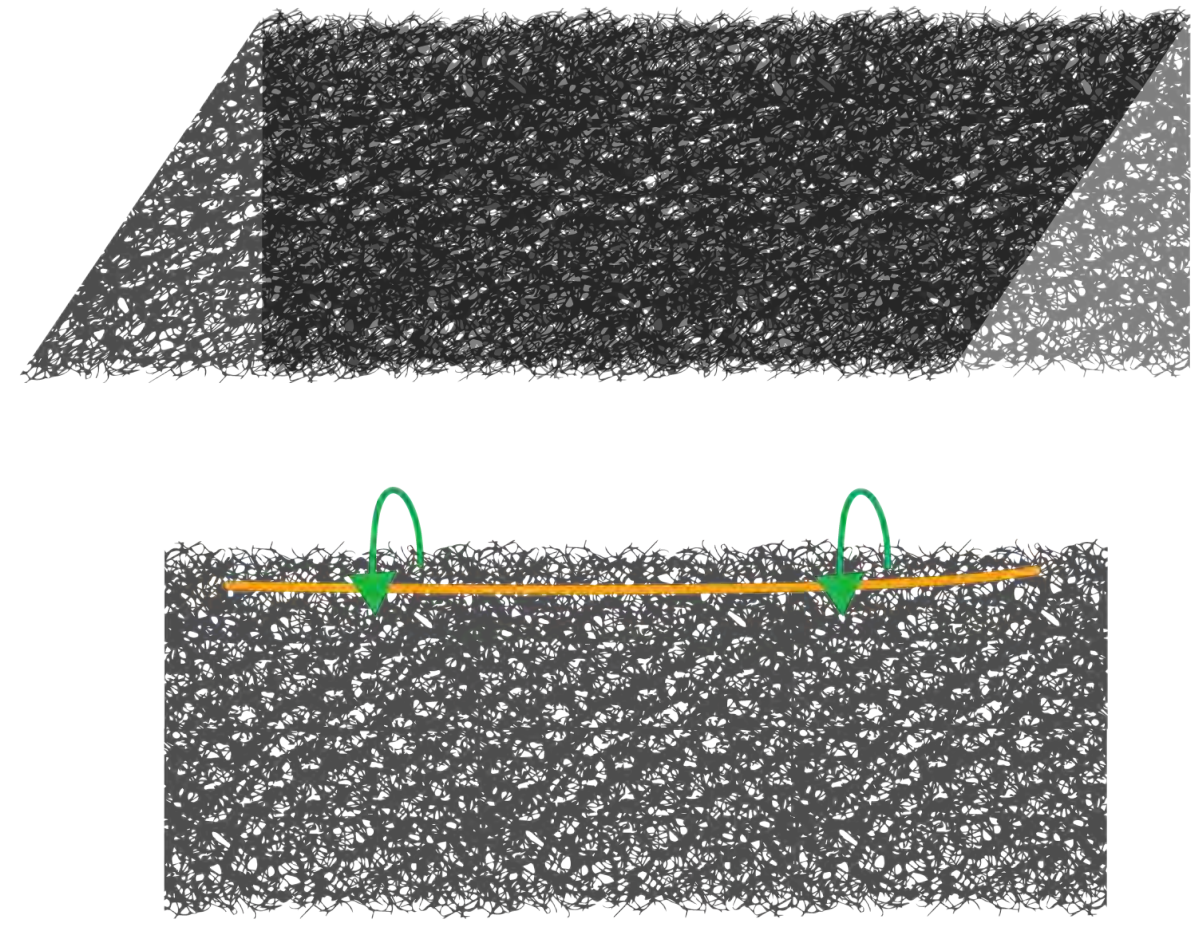

Primero, cosa el lado superior
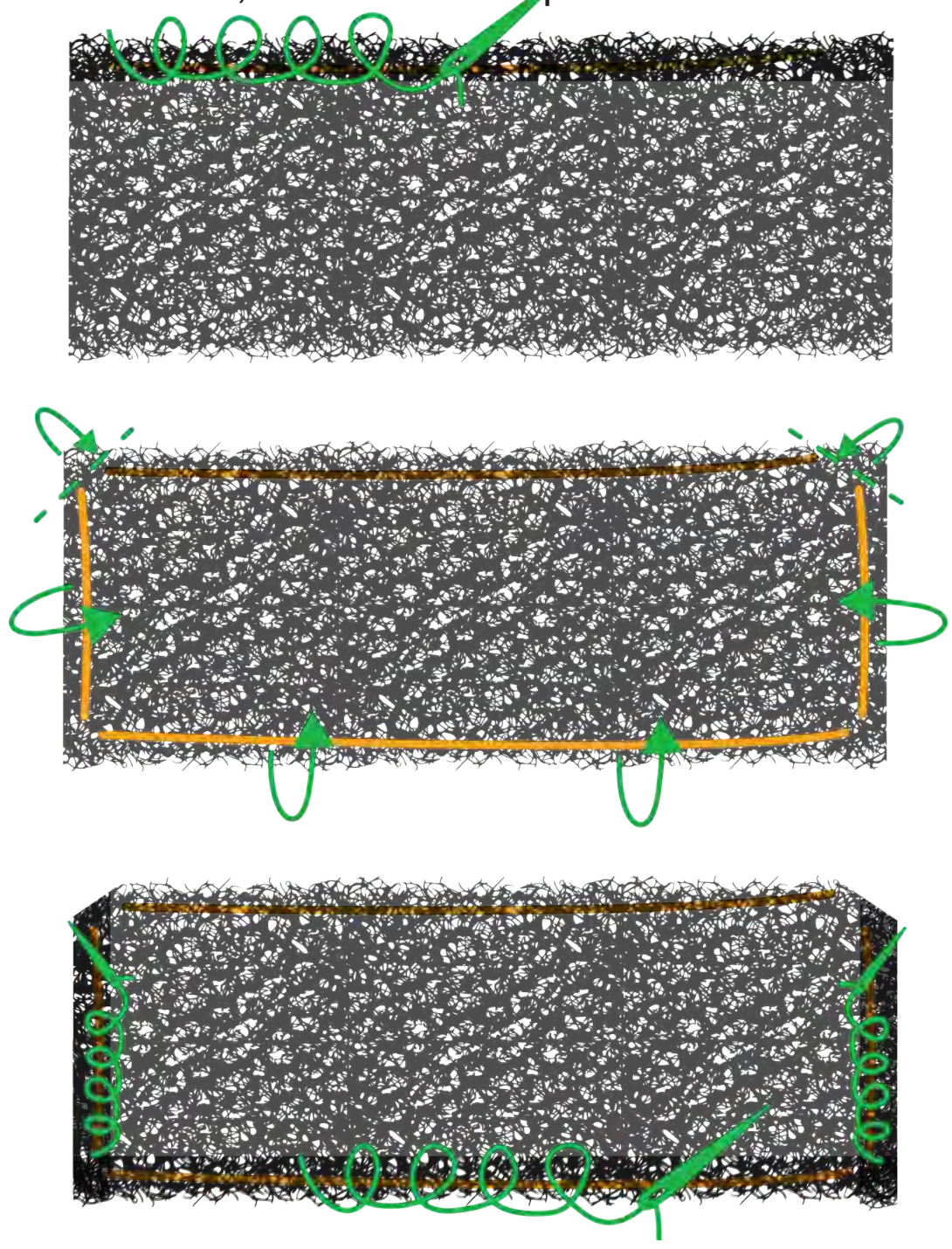

luego cosa el fondo
Dobla la malla en una mitad

Dobla dos capas sobre la malla en cima de la manguera

Cosa la malla en cima de la manguera
Luego cosa la malla a la manguera de la parte inferior. Cosa la malla a las mangueras de los 


\section{Levantando los Postes}

Fija el cable superior entre los dos postes para tener $10 \mathrm{~m}$ de espacio en el centro.

1) Junta el tensor a los cables anclares. El tensor debe estar en la posicion extendida.

2) Adjunta los cables de alambre tipo ( $x 2$ ) al exterior de los ganchos, en cada poste. Estaran $8.5 \mathrm{~m}$ de largo.
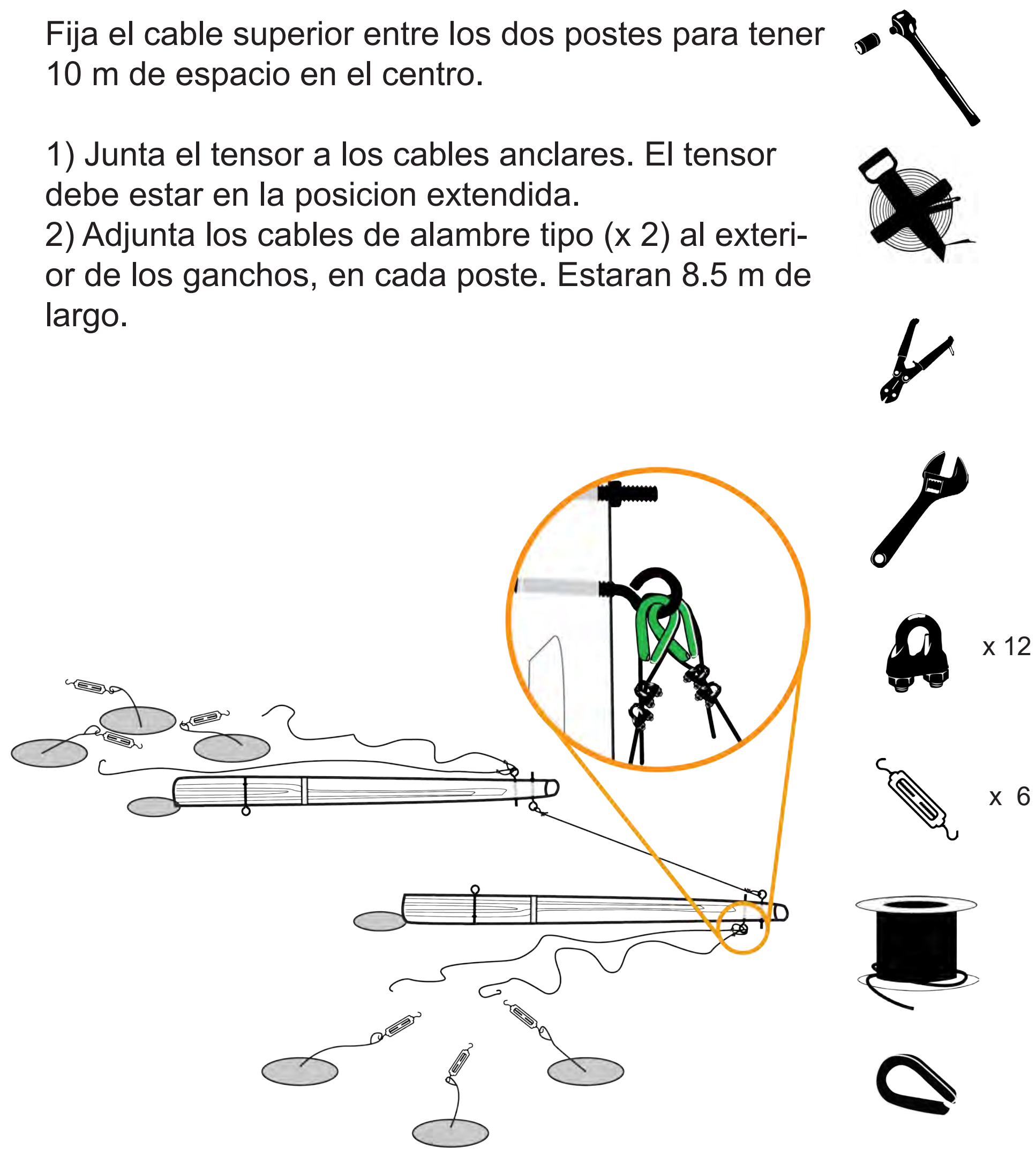
3) Levanta los postes con el cable superior, con los postes dentro de los hoyos.

4) Adjunta cables de alambre tipo para ajustar los tensores usando bucles de cable y abrazaderas. 5) Aprieta el assemblaje con los tensores.
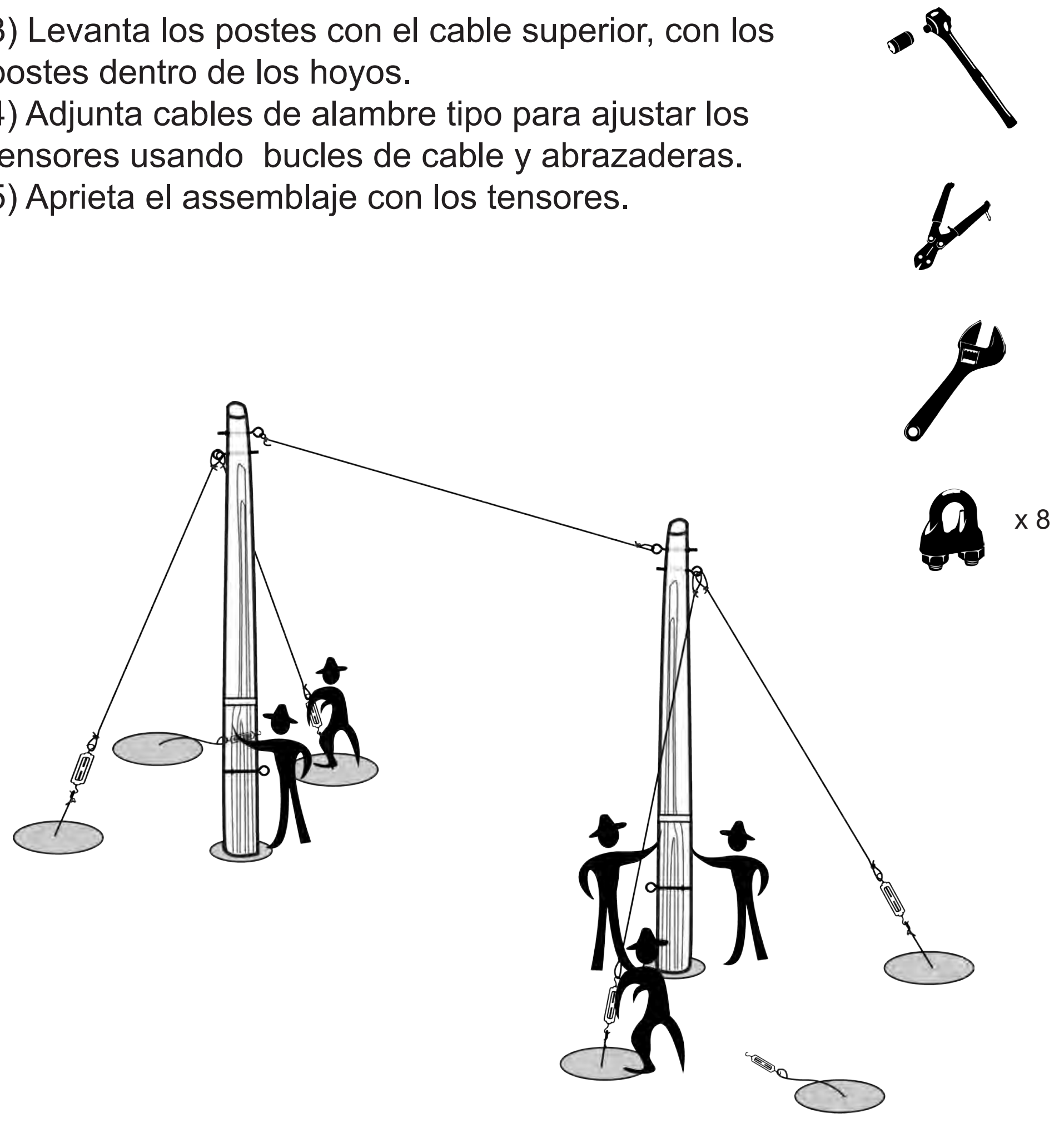


\section{Levantando la Malla}

Corta $23 \mathrm{~m}$ de cable Corta $20 \mathrm{~m}$ de cable

Ponga 23 m de cable entre los lados y la area superior de la manguera

Ponga $20 \mathrm{~m}$ de cable entre la area de bajo de la

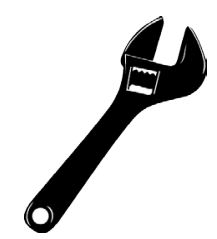
manguera

Une los mosquetones y envoltura de cuerda hace el cable de la esquina superior entre la manguera

la proxima pagina)..
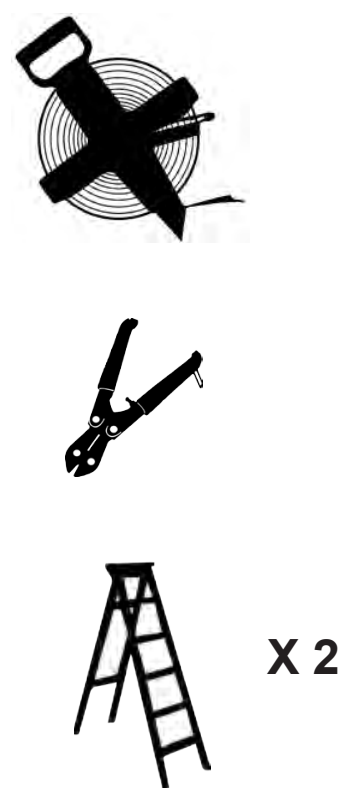

Usando escalera, liga un mosqueton al interior del poste en la area superior con el gancho.

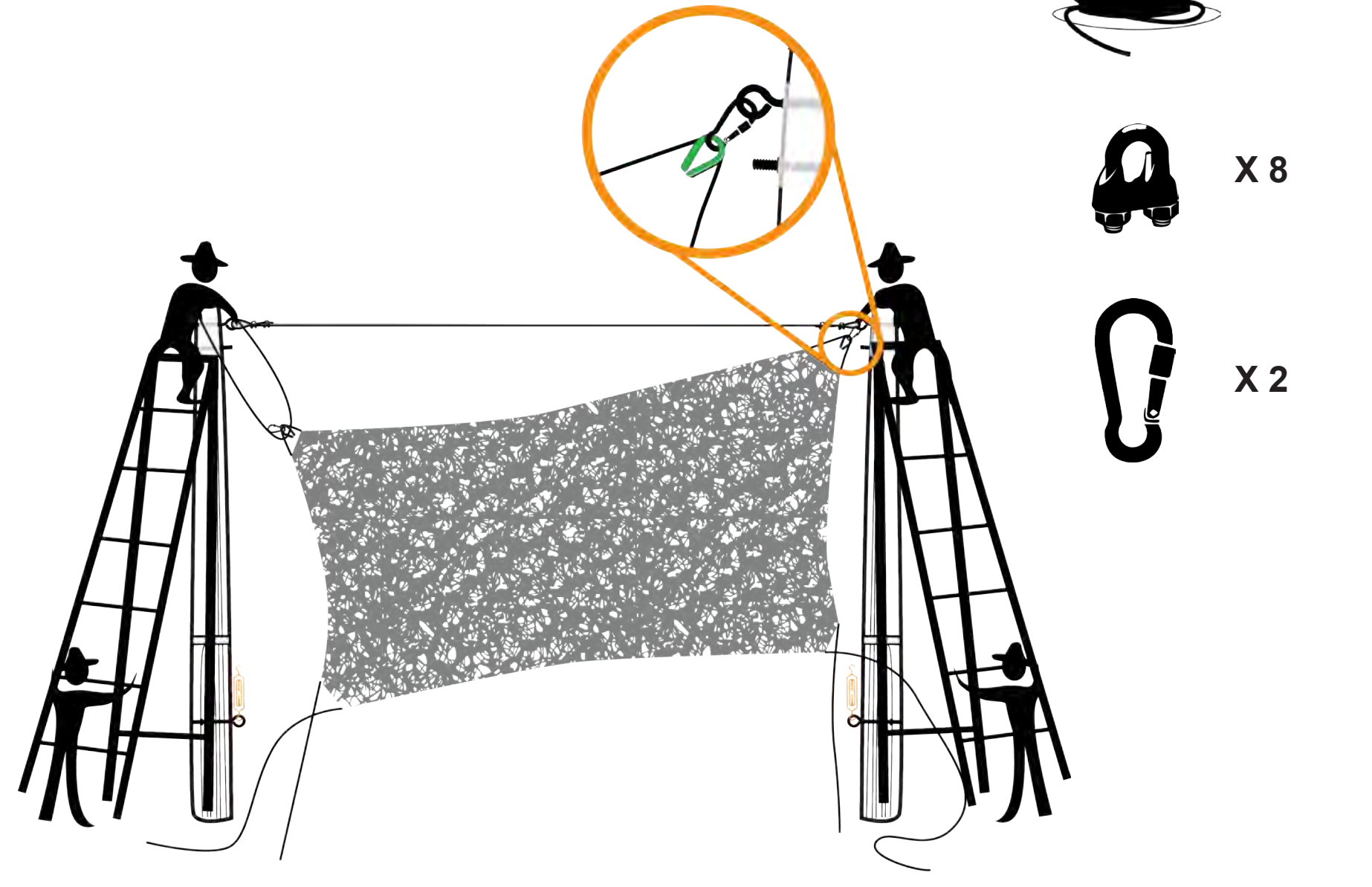


Usando un lazo juntado con el segundo mosqueton, jala la malla hacia arriba para conectar el mosqueton al gancho superior.

Adjunta el tensor al gancho en la area baja del poste. Conecta

Jala el cable inferior (entre la manguera) entre los agujeros hecho en el poste. Adjunta los cables al tensor. Tensiónalo.

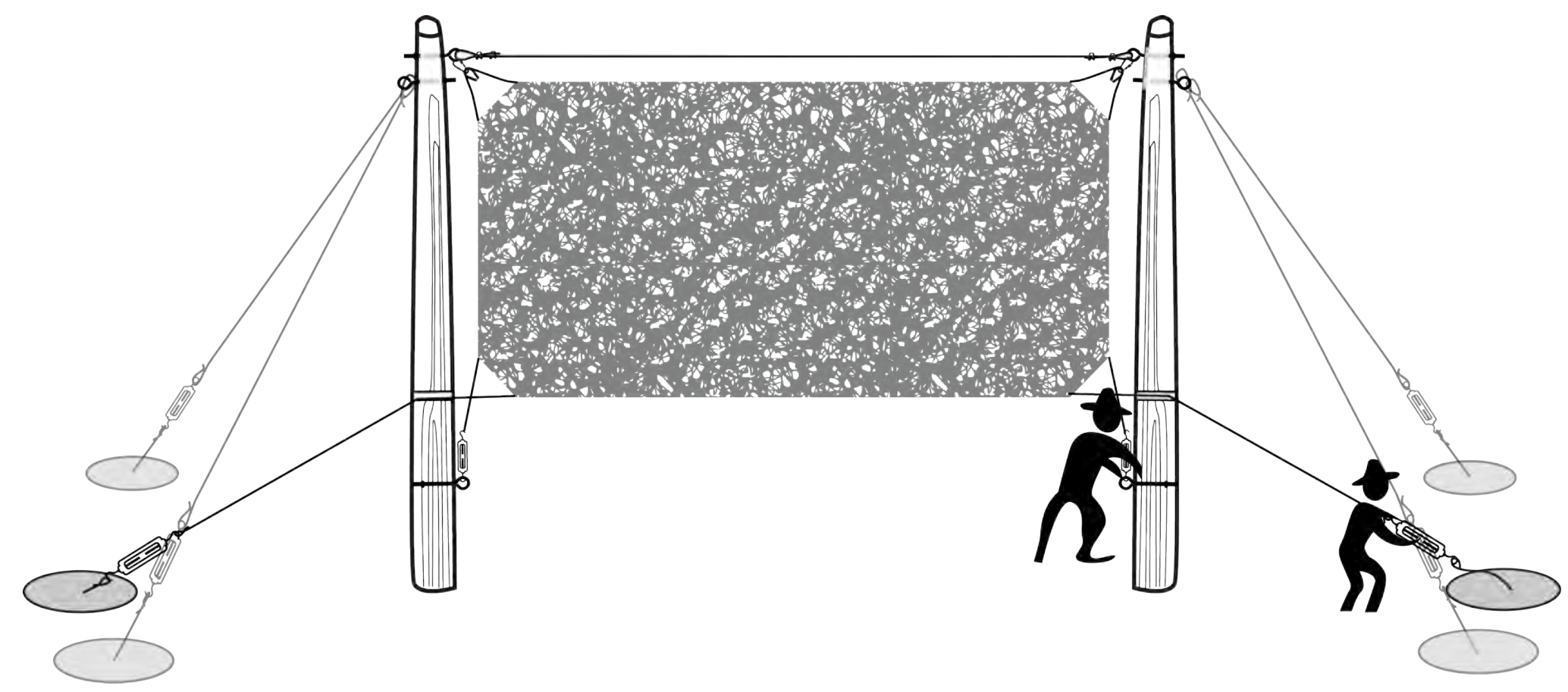




\section{Instalando la canaleta}

Tubo PVC: $9.8 \mathrm{~m}$ de largo

Cosa el tubo PVC a la parte inferior de la malla para hacer un canaleta.
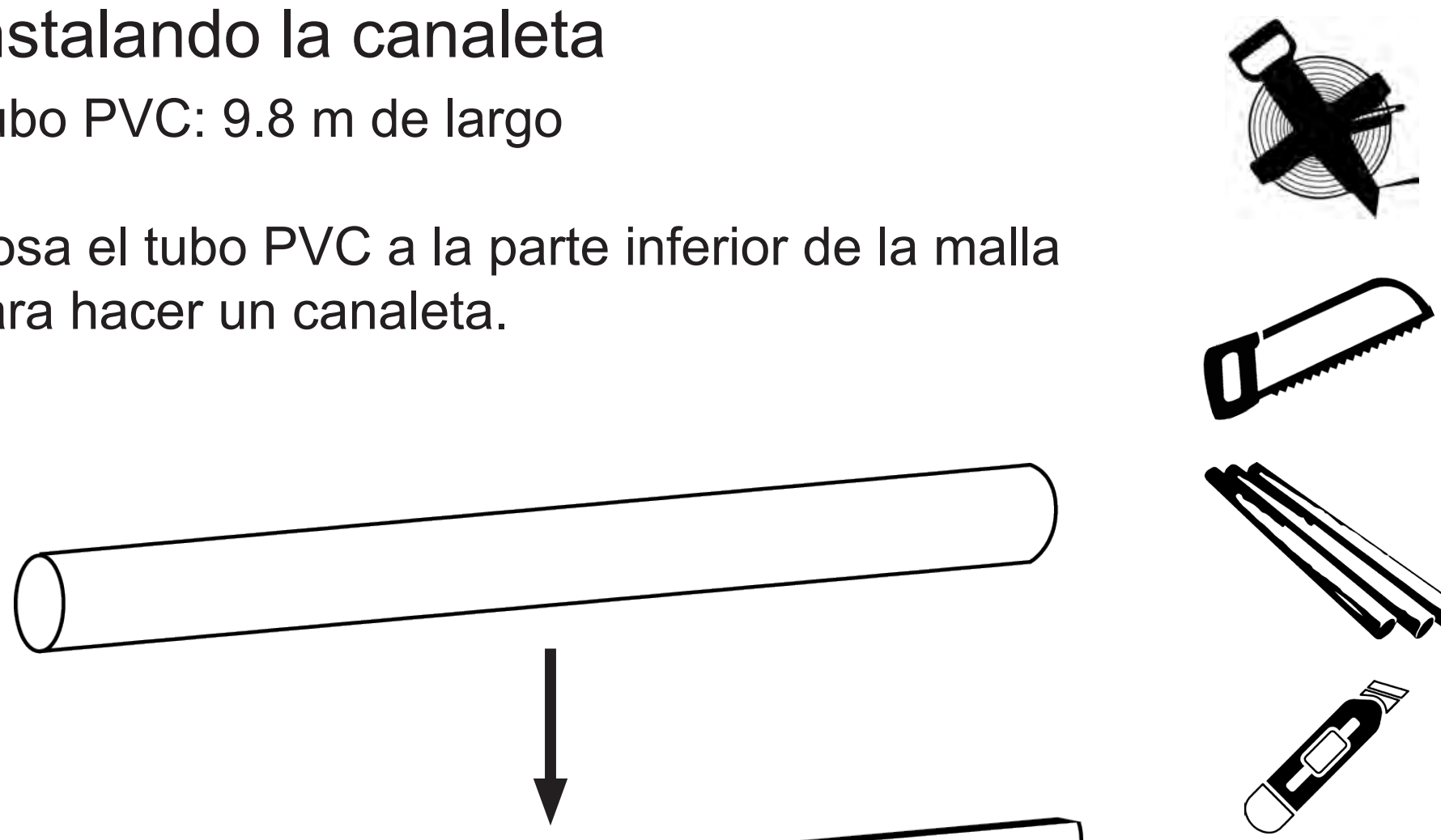

$\sigma$
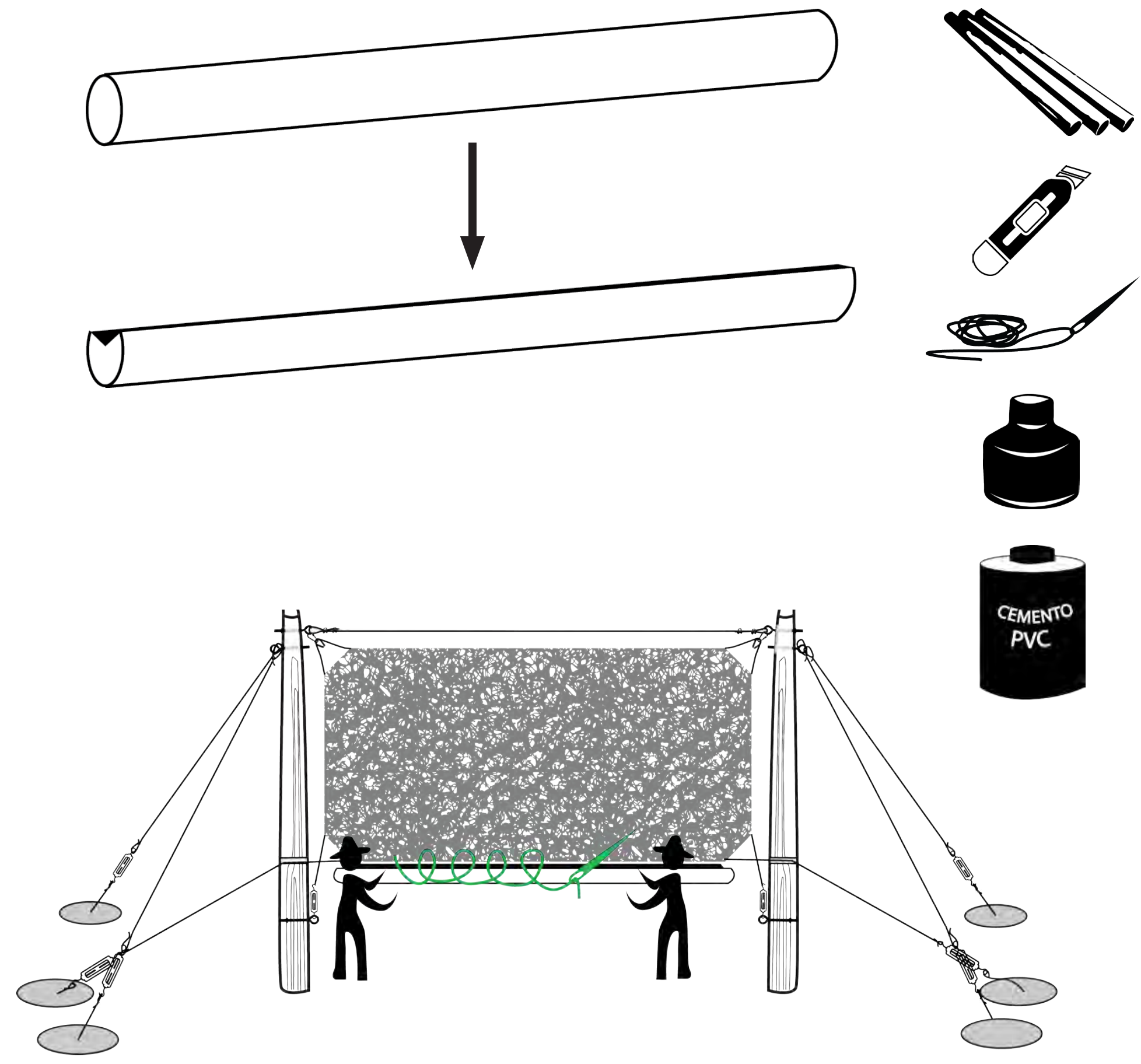


\section{Colectando Agua}

Usa la manguera para adjuntar la canaleta ha un tanque de agua.
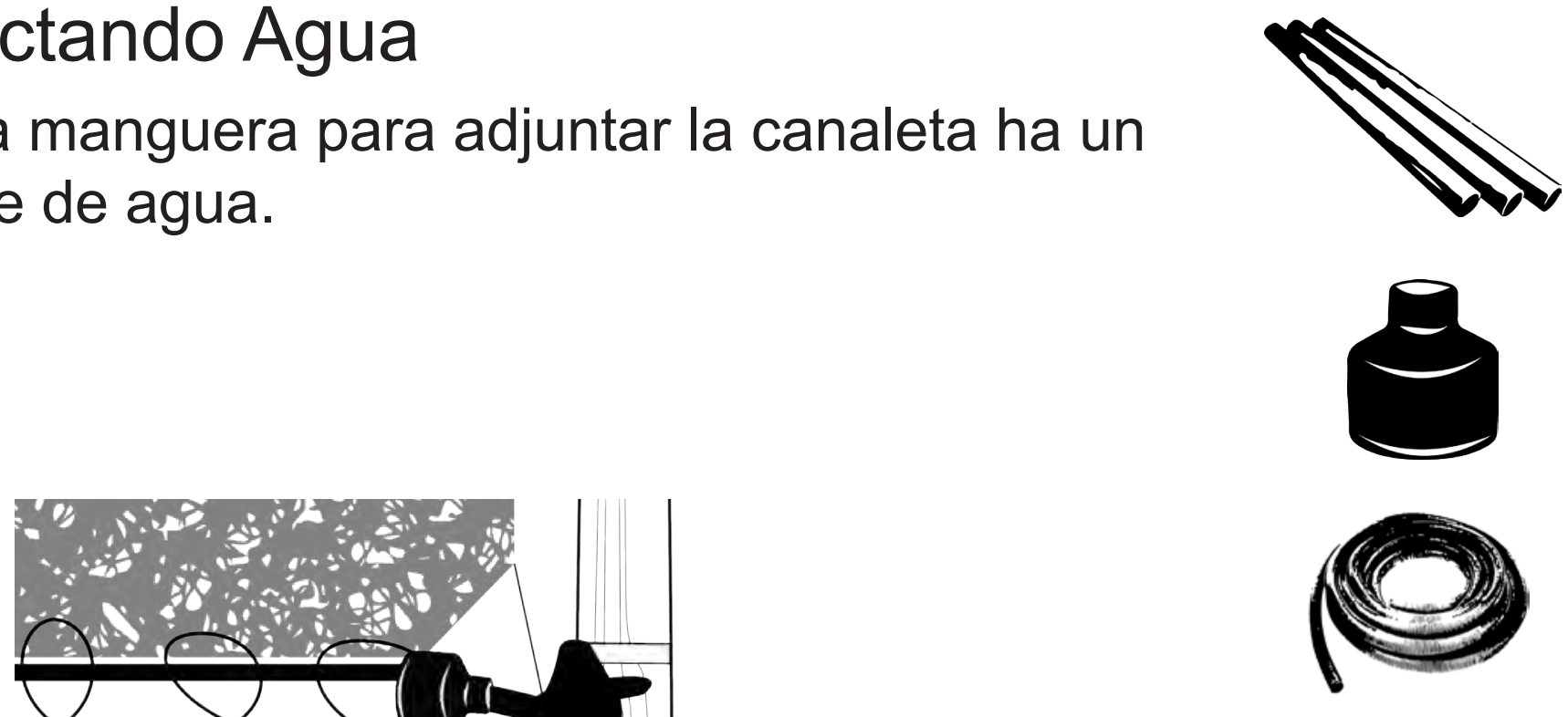

Sigue, MANTENIMIENTO DE ATRAPANIEBLAS... 


\section{Construction and Maintenance Manuals}

Appendix 6: Fog System and Farm Park Maintenance Manual 


\section{Manual de Mantenimiento del Sistema de Riego Del Parque Comunitario en Eliseo Collazos}

Arquitectos sin Fronteras

Informal Urban Communities Initiative

2016 


\section{Contenido}

\section{Página}

Introducción $\quad 2$

1. Los atrapa-nieblas 3

1.1. Explicación del Sistema 3

1.2. Mantenimiento al principio de la época de neblina 4

1.3. Mantenimiento al final de época de neblina 4

2. El tanque de Sedimentación 5

2.1. Explicación del Sistema 5

2.2. Mantenimiento al principio de la época de neblina 6

2.3. Mantenimiento al final de época de neblina 6

$\begin{array}{ll}\text { 3. Los tanques de almacenamiento } & \mathbf{7}\end{array}$

3.1. Explicación del Sistema

3.2. Mantenimiento al principio de la época de neblina

3.3. Mantenimiento al final de época de neblina

4. El sistema de riego por goteo

11

4.1. Explicación del Sistema 11

4.2. Mantenimiento al principio de la época de neblina 12

4.3 Mantenimiento al final de época de neblina 12 


\section{Introducción}

El Parque "Bendición sin Limites" ubicado en Eliseo Collazos cuenta con un sistema de riego que colecta agua de la neblina, la almacena y distribuye por medio de mangues riego por goteo a las jardines del parque. Este sistema está formado por cuatro partes. (ver GRAFICO 1):

1. Los atrapa-nieblas

2. Tanque de sedimentación

3. Tanques de almacenamiento

4. Riego por goteo en los jardines tipo andenes

\section{GRAFICO 1. Sistema de riego por goteo}

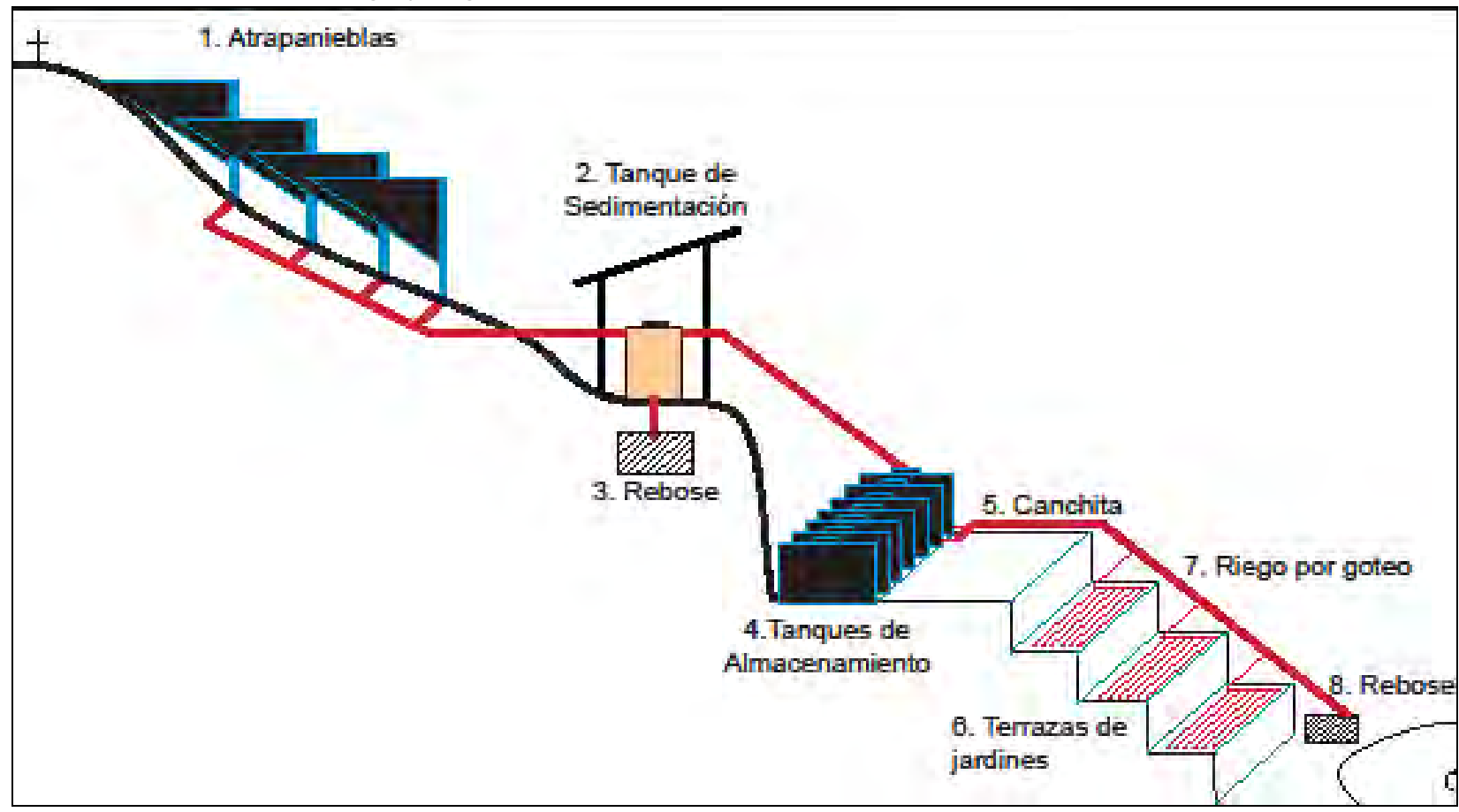

En los siguientes capítulos se detallará cada parte del sistema y el mantenimiento que requiere al principio de la época de neblina y al final de la época de neblina.

OJO: Si en cualquier momento tuviesen problemas de larvas, mosquitos o zancudos en el sistema, es importante avisar a la posta de salud. Ellos pueden acercarse para sacar muestras y limpiar el sistema. 


\section{Los atrapa-nieblas}

\subsection{Explicación del Sistema}

El sistema de riego empieza en los seis atrapa-nieblas ubicados en la parte alta de la comunidad, cerca al cementerio local. Los atrapa-nieblas son estructuras triangulares que tensan una malla. Sus partes y componentes estas detallados en el GRAFICO 2. La neblina al pasar por la malla se condensa y crea gotas de agua en la superficie. Estas gotas de agua, al acumularse, caen a la canaleta. Cada canaleta de cada atrapa-niebla está conectado en serie a una manguera de 400 metros que lleva el agua de los atrapanieblas a los tanques de sedimentación (ver GRAFICO 1).

\section{GRAFICO 2. Detalle de Atrapa-niebla}

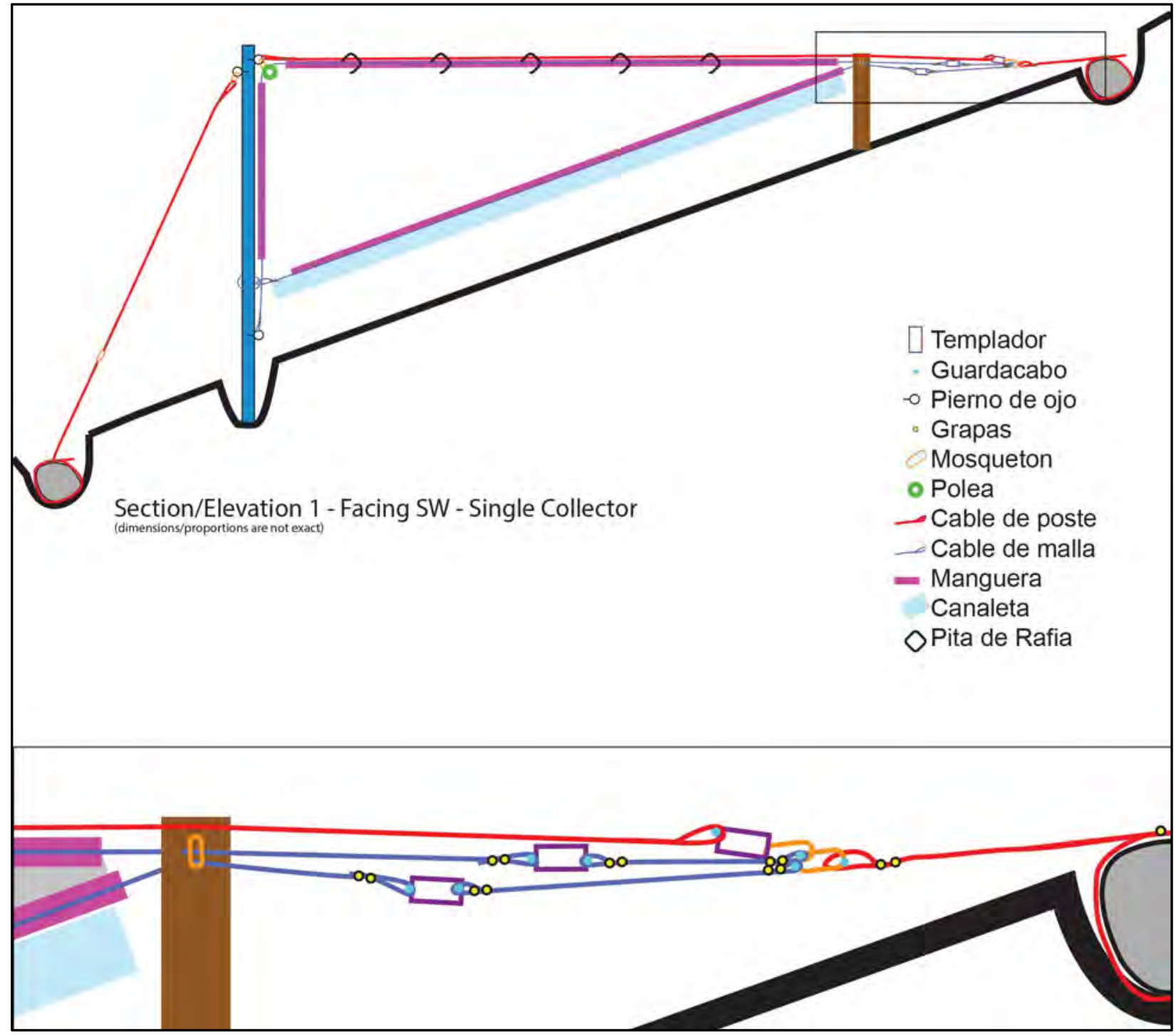




\subsection{Mantenimiento al principio de la época de neblina}

Empezada la época de neblina, es importante instalar las mallas de los atrapa-nieblas para poder colectar agua. Las instrucciones para instalarlas son las siguientes.

(Demora aproximadamente 30 minutos en poner cada una)

OMateriales:

a. Tensador de Cable

b. Llaves

c. Escalera

El proceso para ponerlas es al revés que para sacarlas, explicado debajo.

a. Desenrolla el atrapa-nieblas del plástico.

b. Conecta el cable que no tiene la polea al poste por parte debajo.

c. Poner el tensador al cable al lado de la piedra y cable inferior.

d. Conecta los cables con tuercas.

e. Conecta el cable que tiene la polea al poste por el parte debajo.

f. Conecta el tensador al cable al lado de la piedra y cable superior.

g. Sube la escalera y pon la polea (mantenga el cable en la polea y en la malla).

h. Asegura el tensador de cable que va en la parte superior del atrapa-niebla que esta anclado a la piedra.

i. Pon las canaletas por la parte inferior del atrapa-nieblas.

j. Saca el tensador de cable.

\subsection{Mantenimiento al final de época de neblina}

Es necesario sacar las mallas de los atrapa-nieblas al final de la época de neblina para evitar que se malogren. El viento podría ocasionar que estas se aflojen, como también el sol puede malograr el material de las mismas y a su vez el polvo las llenaría de impurezas. Se deben sacar las mallas y enrollarlas en plástico para protegerlas. Lo que sigue son los pasos para sacar las atrapa-nieblas.

(Demora aproximadamente 30 minutos en quitar cada una).

Materiales:

k. Tenadsor de Cable

I. Llaves

m. Escalera

Proceso:

a. Saca los canaletas por la parte inferior del atrapa-nieblas.

b. Asegura el tenadsor de cable que va en la parte superior del atrapa-niebla que esta anclado a la piedra. Desajusta el cable y desconectarla del perno. Mantenga la " $U$ " en el cable que va en el atrapa-niebla para que el cable no corra en la manguera. 
c. Sube la escalera y saca la polea (mantenga el cable en la polea y en la malla).

d. Desconectar el tensador del cable.

e. Desconecta el cable del poste por el parte debajo que está conectada a la polea.

f. Poner el tensador del cable por parte de la piedra en el cable inferior.

g. Desconecte los cables y mantenga la "U" en el cable con tuercas para que el cable no corra en la manguera.

h. Desconecta el cable del poste.

i. Desconect el tensador del cable.

j. Enrolla el atrapa-nieblas en plástico para que no se ensucie. 


\section{El Tanque de Sedimentación}

\subsection{Explicación del Sistema}

El tanque de sedimentación está colado en una caseta ubicada en el bloque $\mathrm{J}$ de la comunidad de Eliseo Collazos, se puede apreciar desde la losa deportiva. El tanque es beige y tiene un volumen de 2,500 litros. El agua que viene de los atrapa-nieblas, siempre viene con un poco de tierra, este tanque es utilizado para separar el agua de la tierra. El agua ingresa por la parte superior, esta se acumula y permite que la tierra caiga al fondo (se sedimente), luego el agua sale del tanque también por una toma superior, dejando salir agua sin tanta tierra. Con el paso del tiempo, la tierra se va a acumular al fondo del tanque. Para limpiar el fondo del tanque hay una llave de salida en la parte baja del tanque. Esta salida está conectada al rebose 1 que se encuentra aproximadamente a 15 metros del tanque. El rebose 1 es un hueco lleno de piedra chancada y que puede llenarse hasta con 100 litros de agua. (ver GRAFICO 3).

\section{GRAFICO 3}

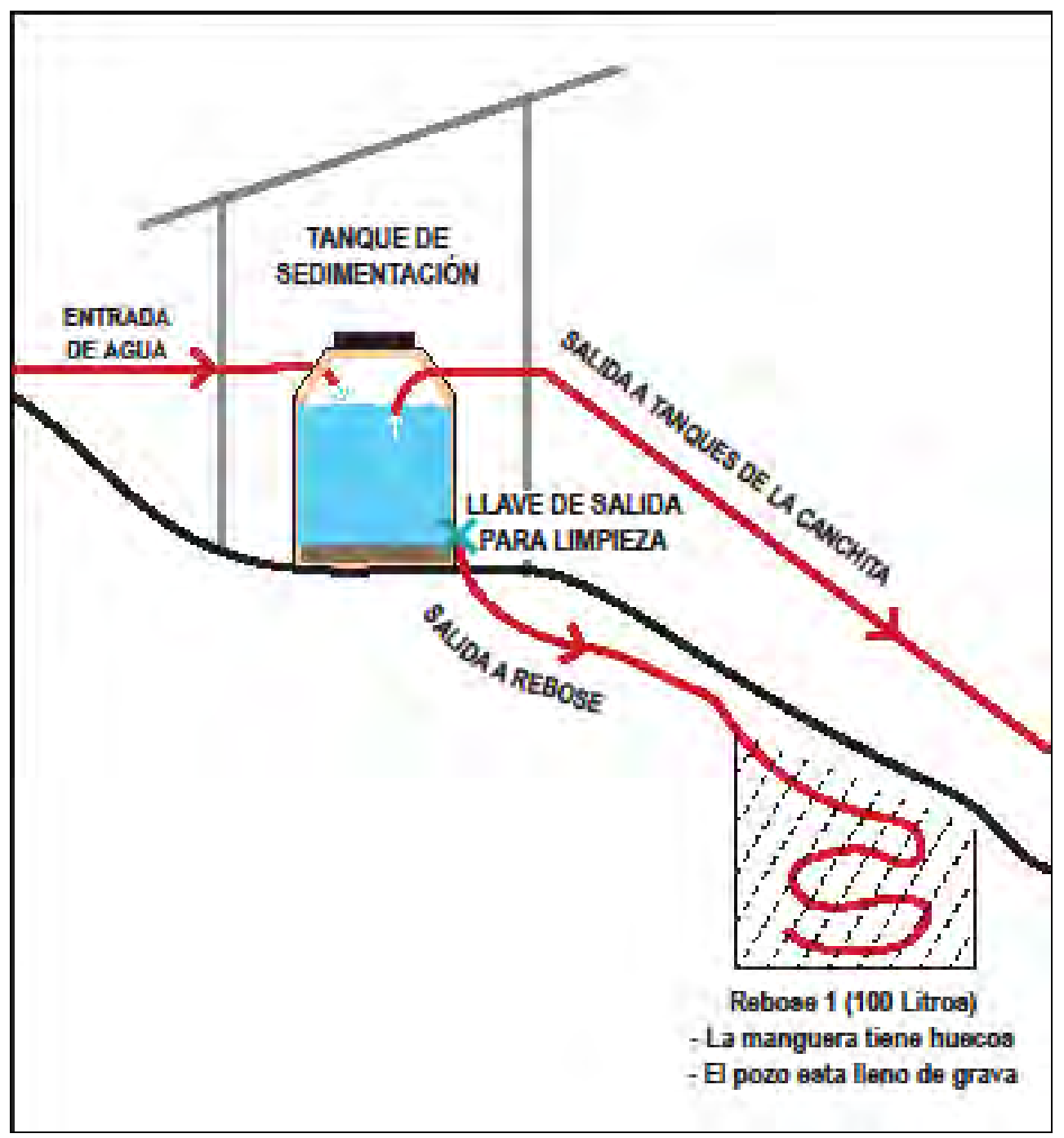


Hay una manera de limpiar el tanque cuando está vacío, y dos maneras de vaciar el tanque cuando está lleno. Las tres maneras usa la llave de salida ubicada en la parte baja del tanque.

1. Cuando el tanque no está lleno: Se llena el tanque con 100 litros, se abra la parte superior del tanque y se cepilla con una escoba todo el interior del tanque. Luego se abra la llave de salida para limpieza y toda el agua con la tierra se ira haca el rebose.

2. Cuando el tanque está lleno: Sigue las instrucciones escrito por el parte adelante del tanque. Vacía el tanque por la salida abriendo la llave para que toda el agua vaya con la tierra se ira haca el rebose. Cuando el tanque empieza de llena esta manera demorara 25 días porque no se puede vaciar más de 100 Litros al día, y el rebose solamente puede recibir 100L al día.

3. Cuando el tanque está lleno: Desconecta la manguera que está conectado al rebose y conectarla a otra manguera libre. Usando esa manguera libre, se puede regar la tierra con la cantidad de agua que se pueda. Esa manera puede vaciar un tanque en solamente 1 o 2 días.

\subsection{Mantenimiento al principio de la época de neblina}

Cuando empieza la época de neblina el agua va a venir con más tierra que en otros estaciones. Por eso, es importante limpiar el tanque de sedimentación cuando esté medio lleno la primera vez. Después, hay que monitorear el tanque. Si se ve mucha tierra en el tubo vertical y transparente que está ubicado adelante del tanque, se necesitará limpiar nuevamente.

\subsection{Mantenimiento al final de la época de neblina}

Cuando termina la época de neblina, hay tres cosas que realizar.

a) Vaciar el tanque.

Hay dos formas de vaciar el tanque:

- Usando el rebose 1. Las instrucciones para vaciar el tanque se encuentran en el mismo tanque. Se necesita abrir la llave que se encuentra en la parte baja del tanque. Deje correr 100 litros de agua, esta agua ira al rebose 1, que tiene una capacidad de 100 litros. Cierre la llave y espere al día siguiente. Repita la operación por los días que sea necesario hasta que el tanque quede vacío, recuerdo no botar más de 100 litros de agua por día o el rebose se rebalsará de agua.

- Desconecte la manguera que se encuentra en la llave en la parte baja del tanque. Conectar otra manguera y dejar correr el agua. Esta agua se puede colectar en baldes y usar para regar jardines.

b) Desconecta la manguera que está entrando el tanque. Aun cuando ya no hay neblina, una cantidad de agua se queda en la manguera. Para que esta agua caiga y se evite llenar el tanque, simplemente desconecte la manguera de entrada de agua.

c) Limpia el tanque. Para que los insectos y bacterias no crezcan en el tanque durante verano, hay que limpiarlo y dejarlo seco. 


\section{Tanques del Almacenamiento}

\subsection{Explicación del Sistema}

Los siete tanques tienen un volumen de 5,000 litros cada uno, y están ubicados a un lado de la losa deportiva. Los tanques tienen números del 1 al 7 como en el siguiente diagrama.

\section{GRAFICO 4}
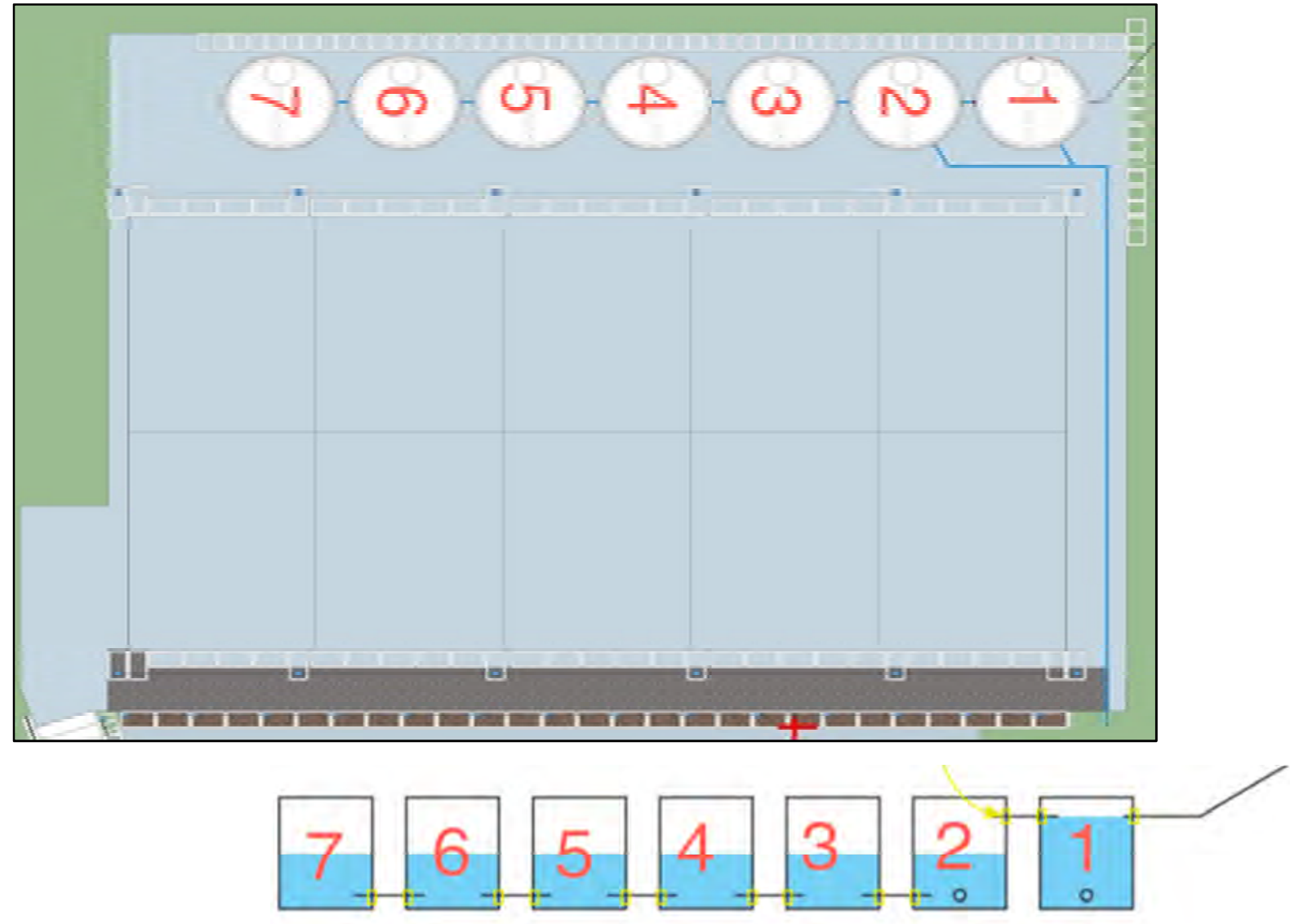

Los siete tanques reciben agua desde el tanque de sedimentación por una manguera de 3/4" (tres cuartos de pulgada). Entre cada uno de los siete tanques hay un tubo de PVC de 2" (dos pulgadas) para conectarlos.

En el diagrama superior se aprecia que existe una conexión entre los tanques 1 y 2 que es elevada y las siguientes conexiones son en el suelo. Si se cierra la llave Para eso, el tanque 1 puede ser independiente si la llave 3 (explicado en la siguiente sección) está cerrada. Es importante que el tanque 1 esté independiente a los demás al principio de la época de neblina porque significa que puede llenarse más 
rápido. Si los siete fueron conectados, tomará más tiempo en llenar todos los tanques. Pero, al estar el tanque 1 independiente, éste puede llenarse primero y dar presión al sistema de riego.

Las conexiones en el suelo están protegidas con una caja de madera. La caja los protege del sol y de niños para que no se malogren.

\section{Las Llaves}

Existen tres llaves en los siete tanques que se usa para regular el flujo de agua. El tubo de PVC a cada llave es $3 / 4 "$. Las tres llaves existen en los siguientes lugares.

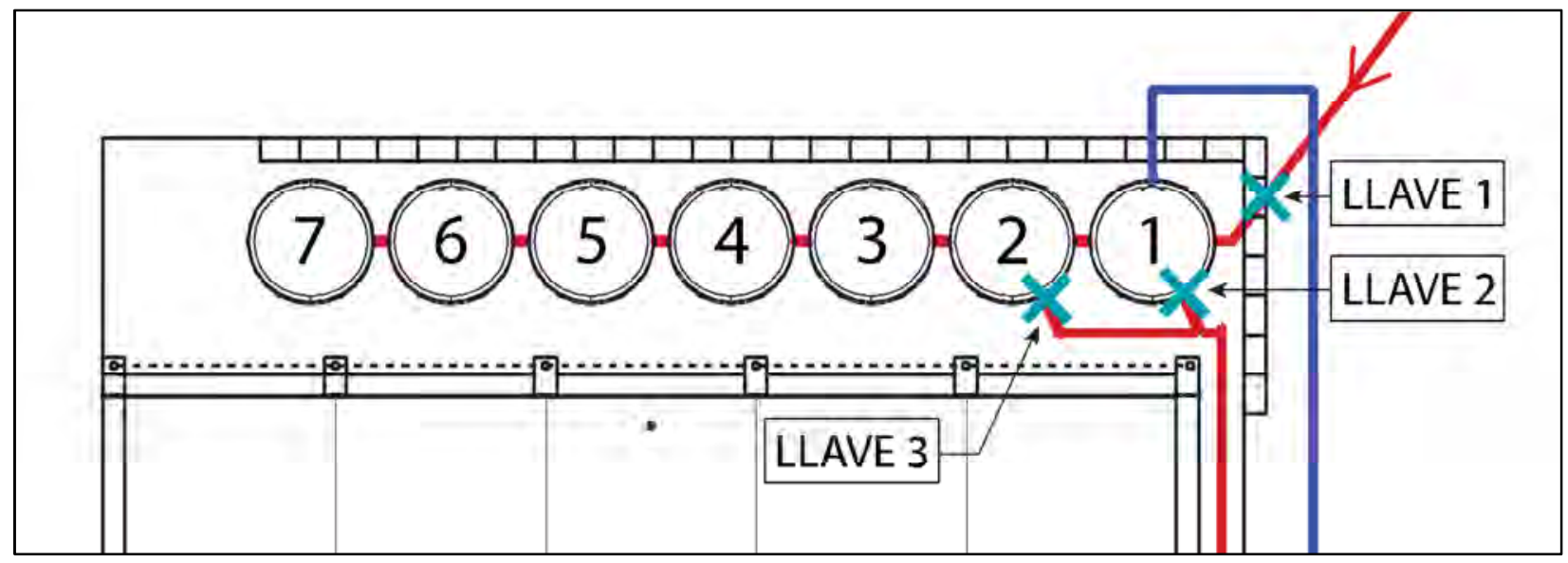

a. Llave 1 está en la entrada del tanque 1 y conectada al tanque de sedimentación. Ésta llave siempre debe estar abierta, a menos que se estén haciendo cambios de manguera.

b. Llave 2 está en la salida del tanque 1. Ésta llave se puede dejar abierta. Se puede cerrar la llave para hacer cambios al sistema de irrigación.

c. Llave 3 está en la salida del tanque 2. Esa llave hay que dejarla cerrada hasta que todos los tanques del 2 a 7 estén llenos. Cuando están llenos, se puede abrir esa llave.

OJO: Si abrimos la llave 3 antes que los tangues del 2 al 7 estén llenos, vamos a minimizar la altura en el sistema, por lo cual va a minimizar la presión en el mismo. Por eso, queremos debemos cerrado hasta que los tanques del 2 al 7 estén llenos.

\section{El Rebose}

Existe un rebose (Rebose 2, en el diagrama abajo) que sale de la parte arriba y a la espalda de tanque 1. La línea de PVC tiene una medida de 1" que cambia en jardín 1 a una manguera de 3/4" y sigue hasta un pozo de grava en la pista. Funciona para eliminar agua si hay demasiada en los tanques. El agua que sobre sale va a pasar por el PVC y manguera hasta el rebose en la pista. El rebose tiene capacidad de 1,000 litros. El diagrama abajo enseña el sistema. 


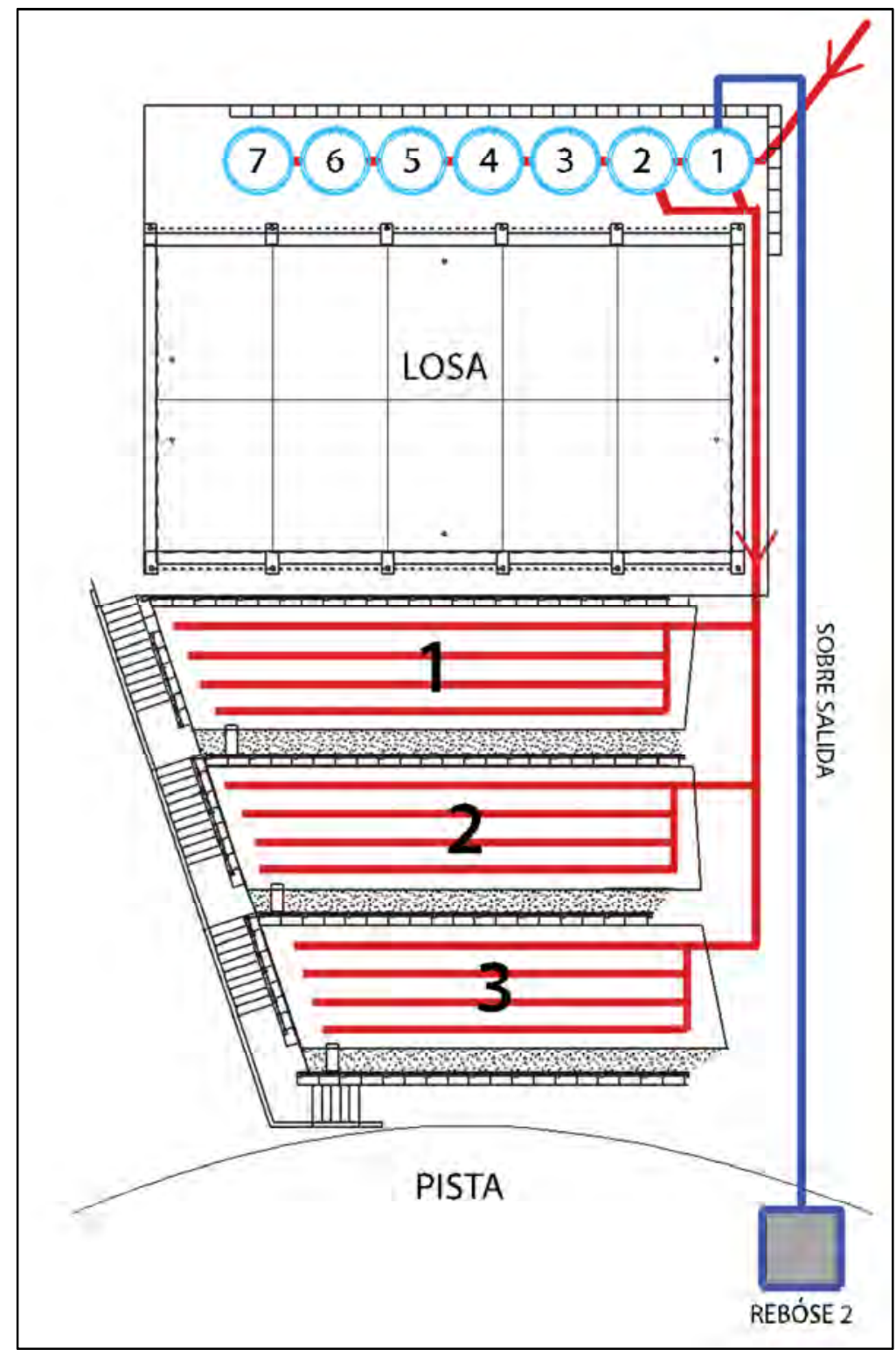

Si agua él está sobresaliendo del sistema significa que hay demasiada agua. Se puede hacer una de tres cosas para cortar el agua.

a) Vaciar el agua del tanque de sedimentación usando su Rebose 1.

b) Desconectar los atrapa-nieblas de sus mangueras en la parte arriba.

c) Vaciar el agua de los tanques de almacenamiento en la línea de riego (explicado en el parte que sigue).

\section{Mantenimiento al Principio de la Época de Neblina}

Al principio de la época de neblina se necesita verificar que las llaves 1 y 2 estén abiertas y la llave 3 esté cerrada.

Mantenimiento al Final de la Época de Neblina 
Al fin de la época de neblina todos los tanques del 1 al 7 deben estar llenos y todas las llaves deben estar abiertas. 


\section{El Sistema de Riego por Goteo}

\subsection{Explicación del Sistema}

El sistema de riego empieza en la salida de los tanques de agua. El tubo de PVC tiene una medida de 3/4" y cambia cuando pasa la "llave principal" a una manguera de 3/4". Esa manguera principal llega al jardín 1, jardín 2 y jardín 3 . El sistema de riego está dividido en 3 partes iguales e independientes - una para cada jardín. En cada jardín, la manguera principal está conectada a una llave que regula el agua para el jardín. En la llave, la manguera cambia a una de 1/2" para mantener la presión. Es recomendable regar cada jardín de manera independiente para así mantener la presión en el sistema. Es decir, solo se abre una llave de jardín por vez. El jardín más alto es jardín 1, el del medio es el jardín 2, y el jardín más bajo y cerca de la pista es el jardín el 3. En el diagrama de abajo se explican las llaves del sistema.

Jardín 1: Tiene dos llaves - una para el sistema de riego por goteo, y una para regular una manguera.

Jardín 2: Tiene dos llaves - una para el sistema de riego por goteo, y una para regular una manguera.

Jardín 3: Tiene una llave para el sistema de riego por goteo.

Si se necesita vaciar los tanques se desconecta la manguera de riego de la llave del jardín 3 y se conecta otra manguera que llegue hasta el rebose 2 . Abrir la llave y dejar que el agua corra, siempre teniendo

GRAFICO X

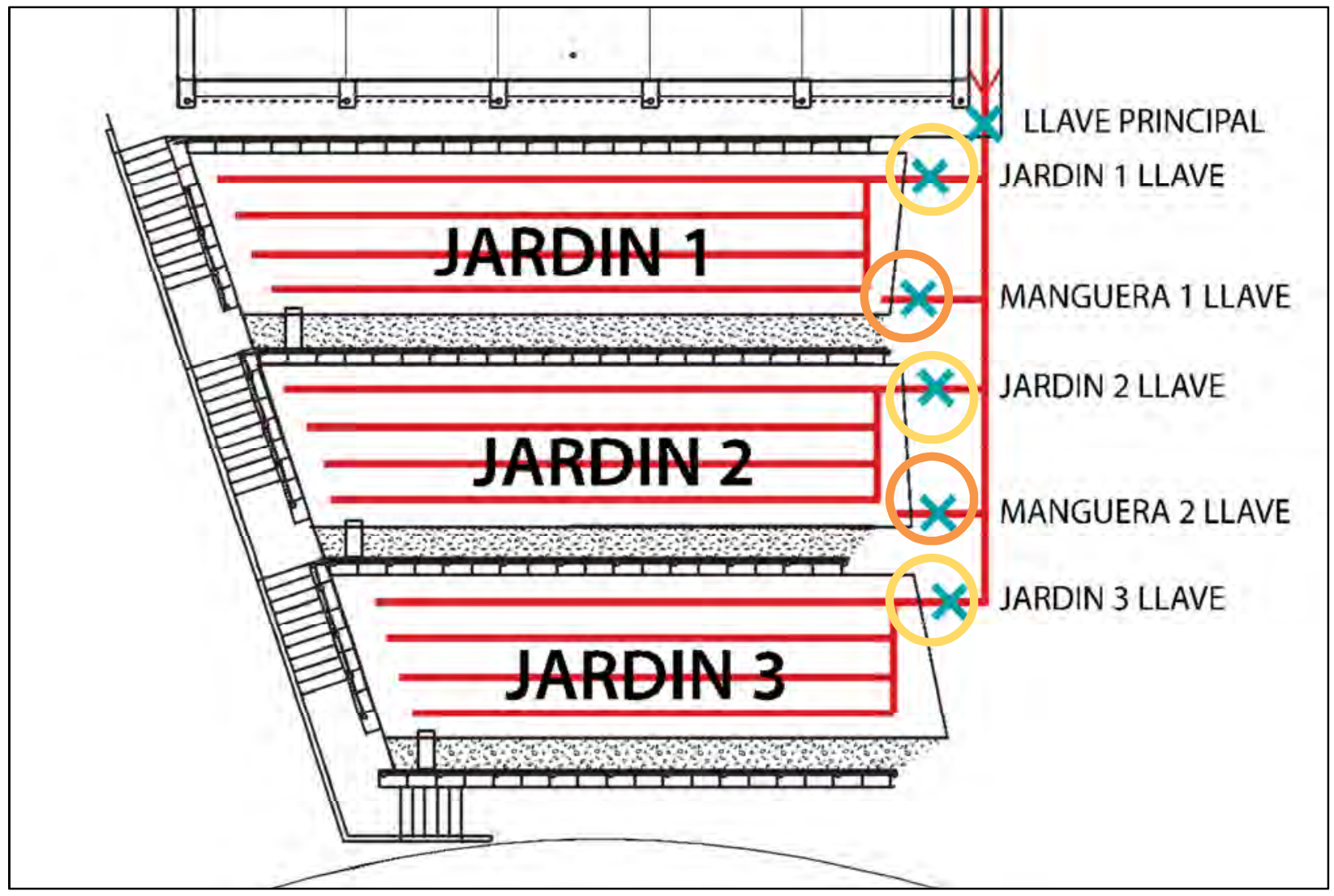




\subsection{Mantenimiento al principio de la época de neblina}

Al inicio de la época de neblina es importante revisar que todos los goteros estén funcionamiento correctamente. Los goteros se pueden regular para que salga más o menos agua si es necesario.. Verificar que las uniones de mangueras y tuberías no estén goteando. Agregar cinta de gasfitería si es necesario.

\subsection{Mantenimiento al final de la época de neblina}

No hay otro tipo de mantenimiento cuando termina la época de neblina. Hay que verificar y regular los goteos como también las uniones.

OJO: Las plantas deben ser regadas en las noches 3 veces por semana 
Project Images

Appendix 7: Project Overview 

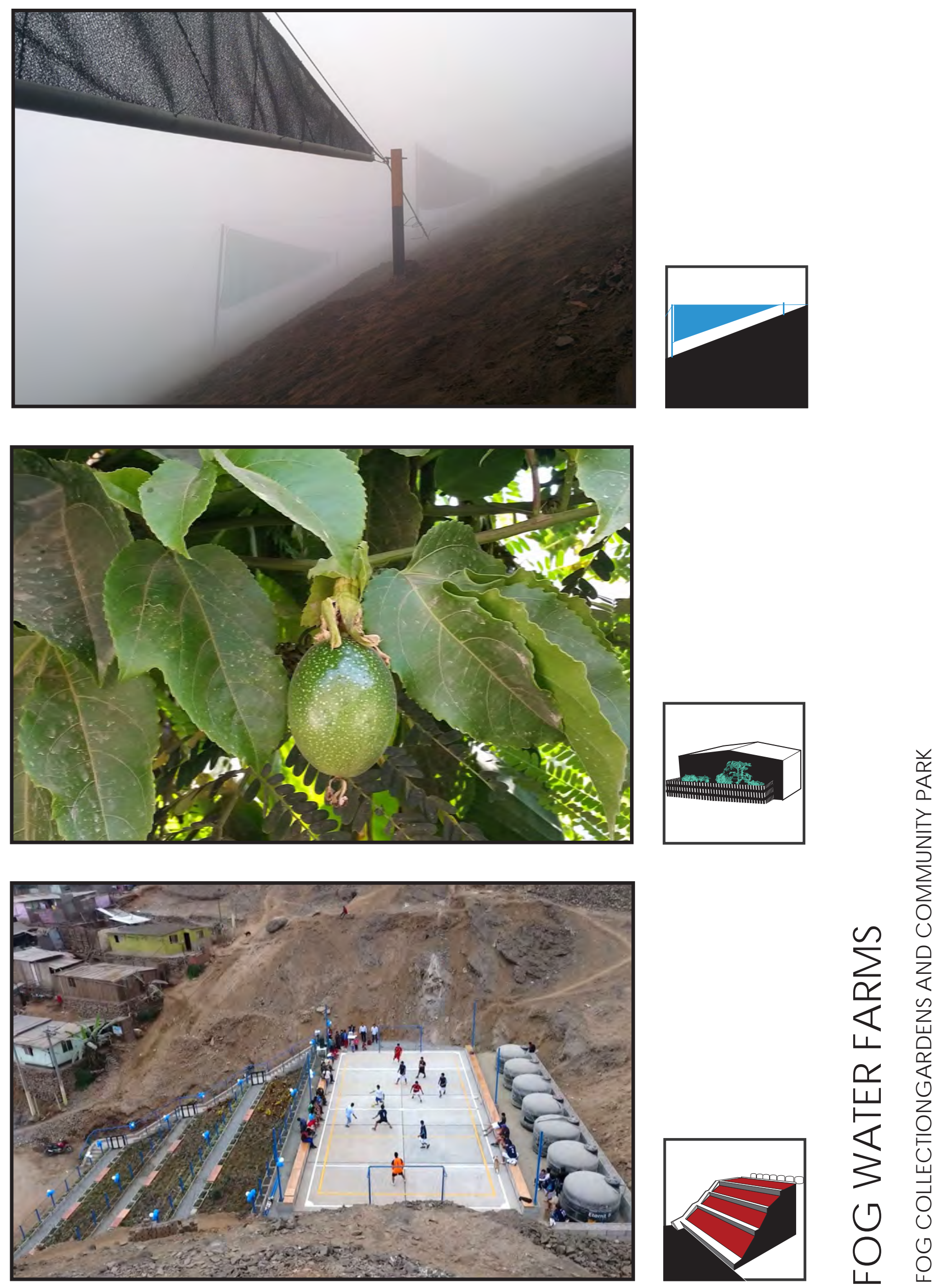


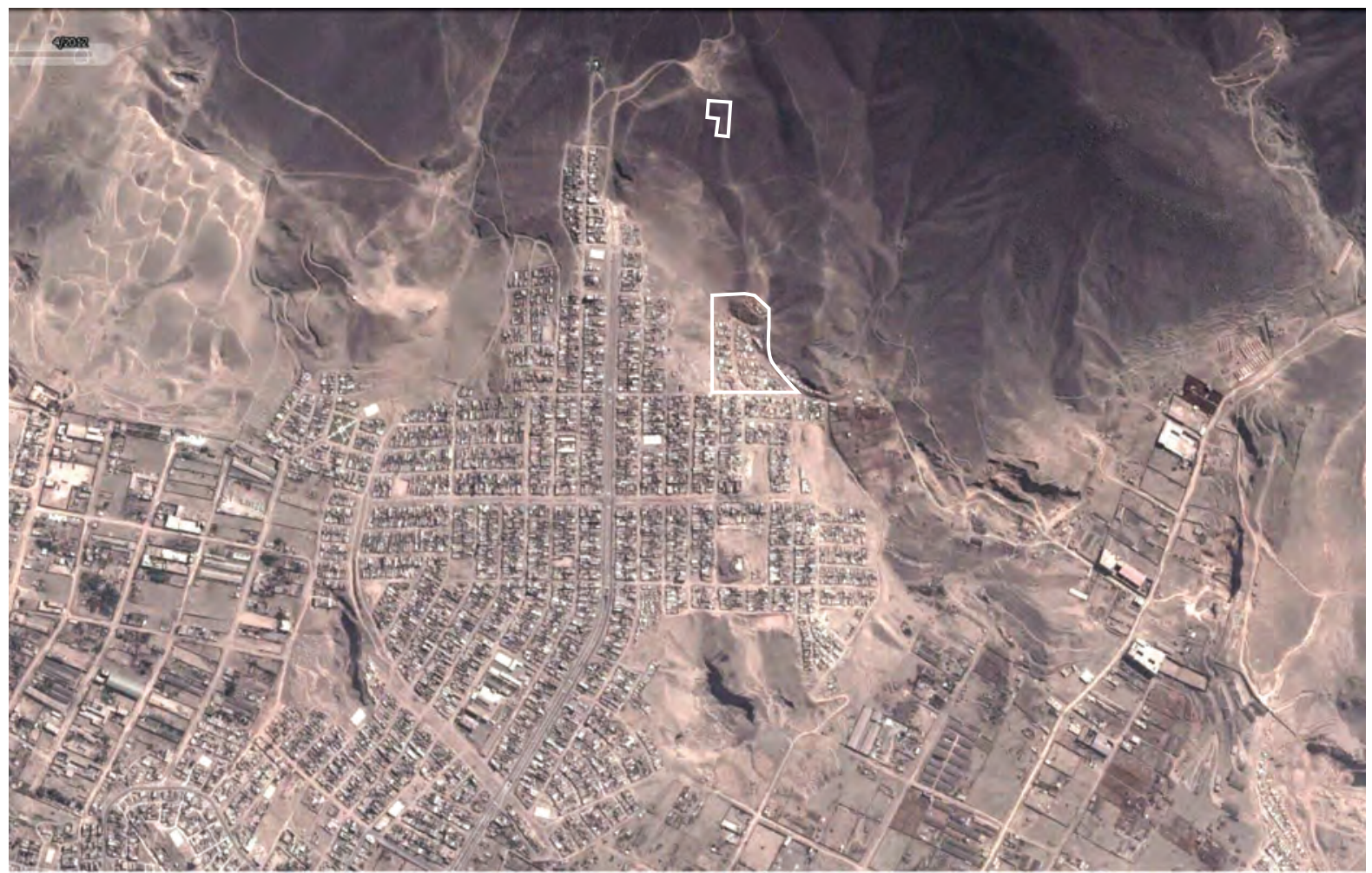

Lomas de Zapallal

- Population_27,000 (est.)

- 19 neighborhoods: 0 to 24 years old

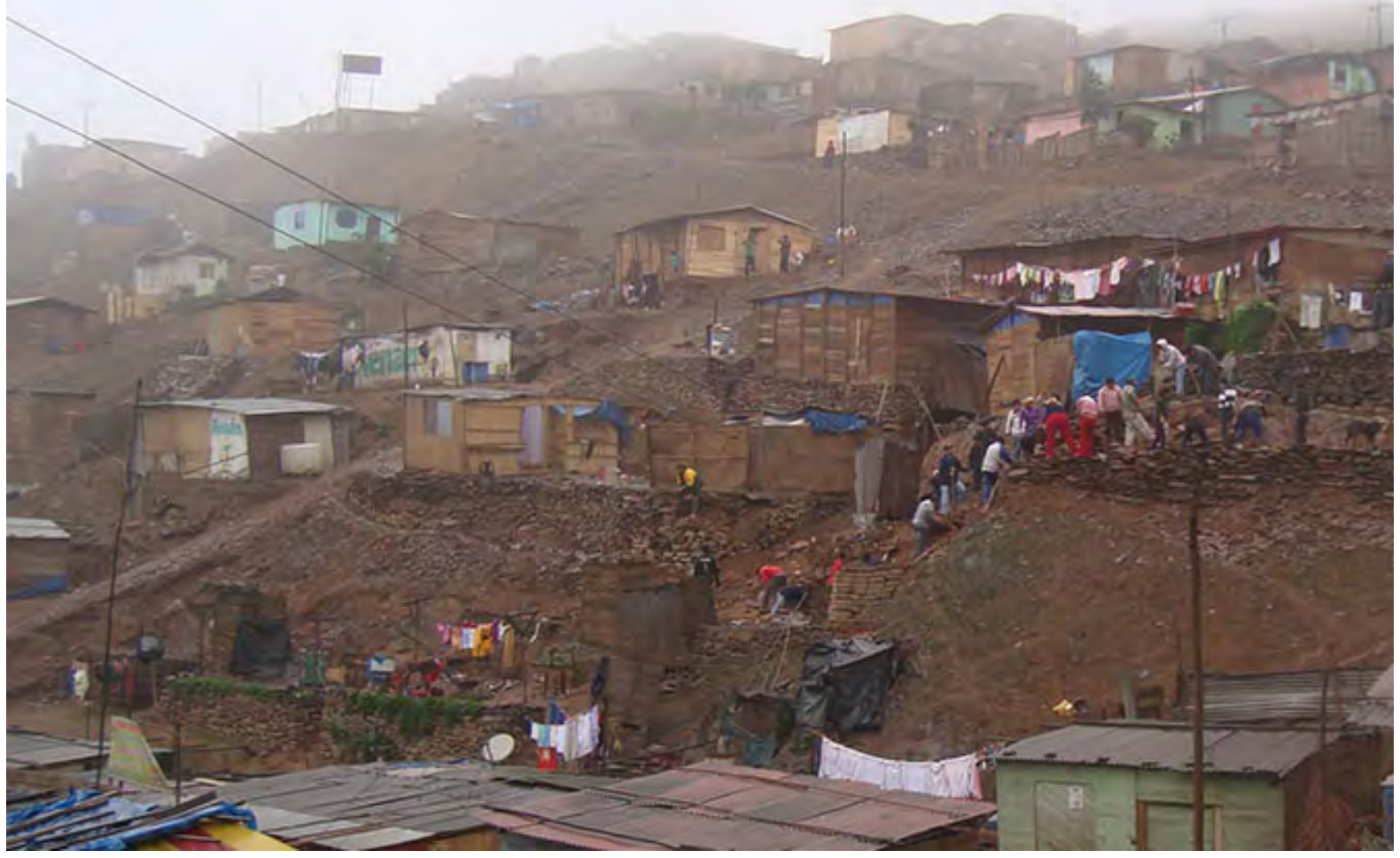

Elise o Collazos (EC)

Note: All imagescredited to AWB-S IUCI team

- H-90 Households

- Established in $+/-2008$

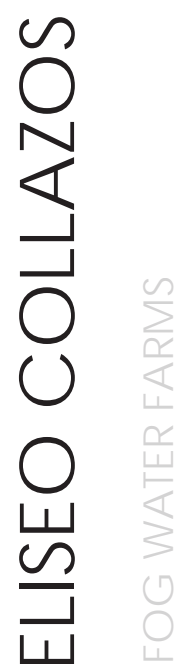



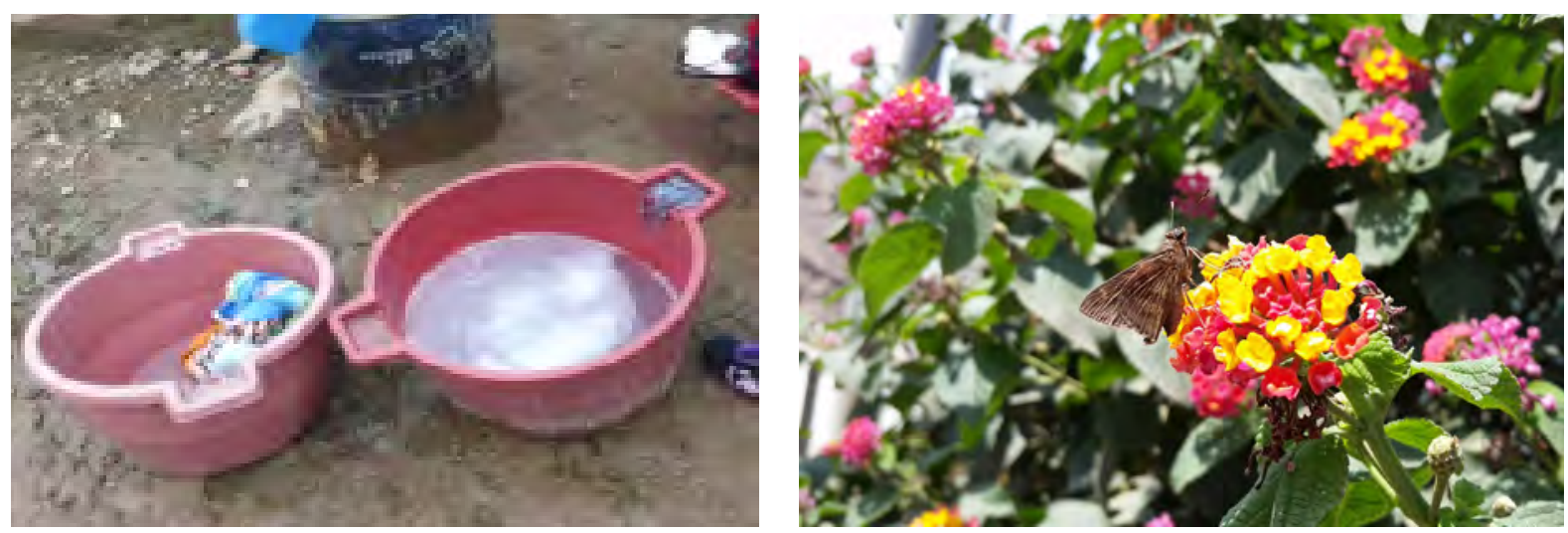

Durign participatory priorities assessments, residents of EC identified water security and public green-space as key priorities. The FWF's fog collection system, household gardens and community park respond to these prionities.

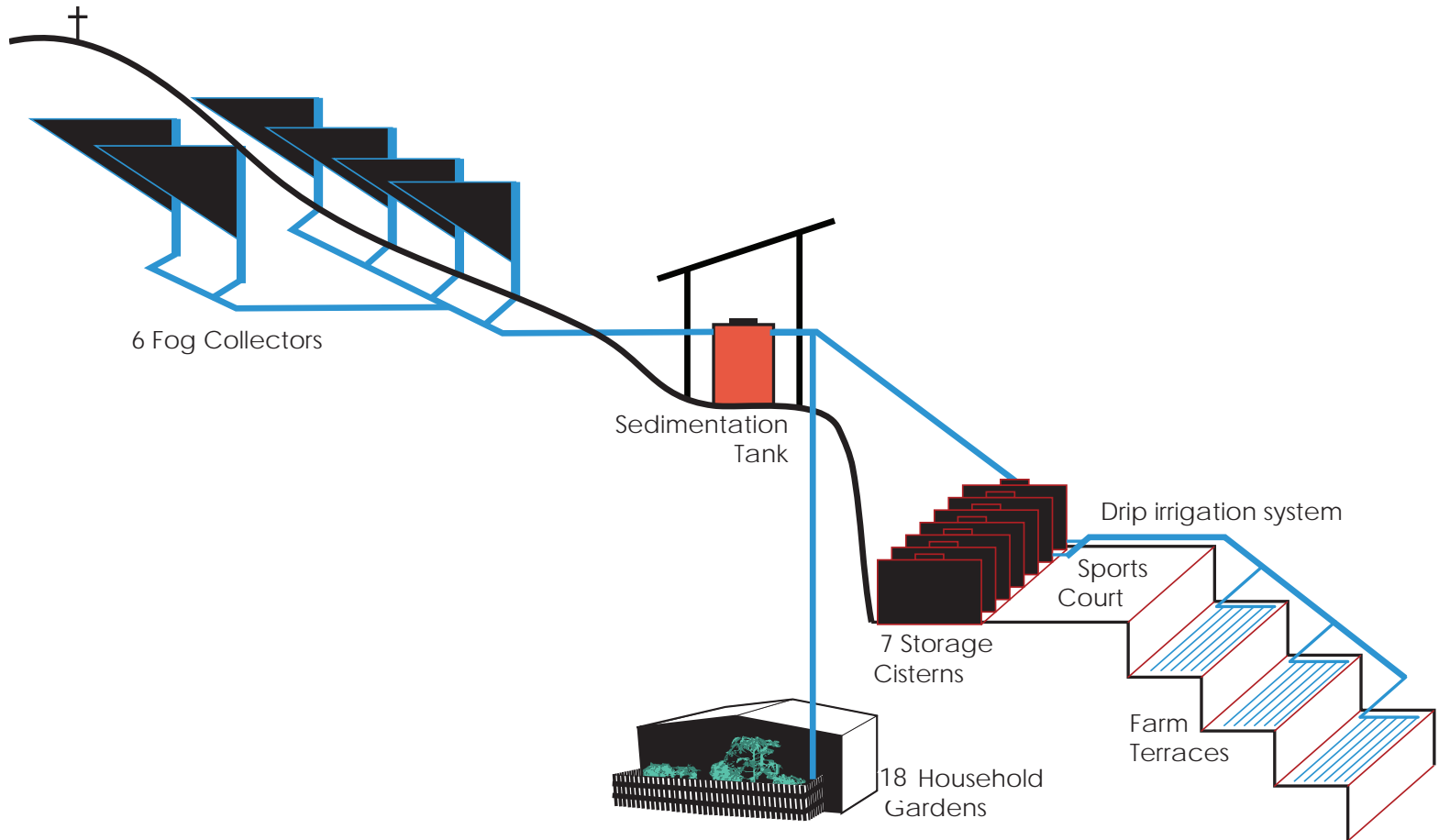

Fog Collectors

- Novel tria ngular design for fog collection on steep slopes

- Improved fog collection materials

- Cumula tive a rea of $157 \mathrm{~m}^{2}$

- Collects up to 1,650 liters $\left(10.5 \mathrm{l} / \mathrm{m}^{2}\right)$ perday

\section{Housahold Gardens}

Utilize a low-cost, a dapta ble, kit-of-parts approach to garden construction

- Planted omamental, medic inal and edible trees, shrubs and herbs space into an area of recreation, relaxation and productivity
- Transforms an unsafe

- Water storage, productive green-space, a soccer/ volleyball court, seating, a stairway, and improved pathways

- Improves slope sta bility 


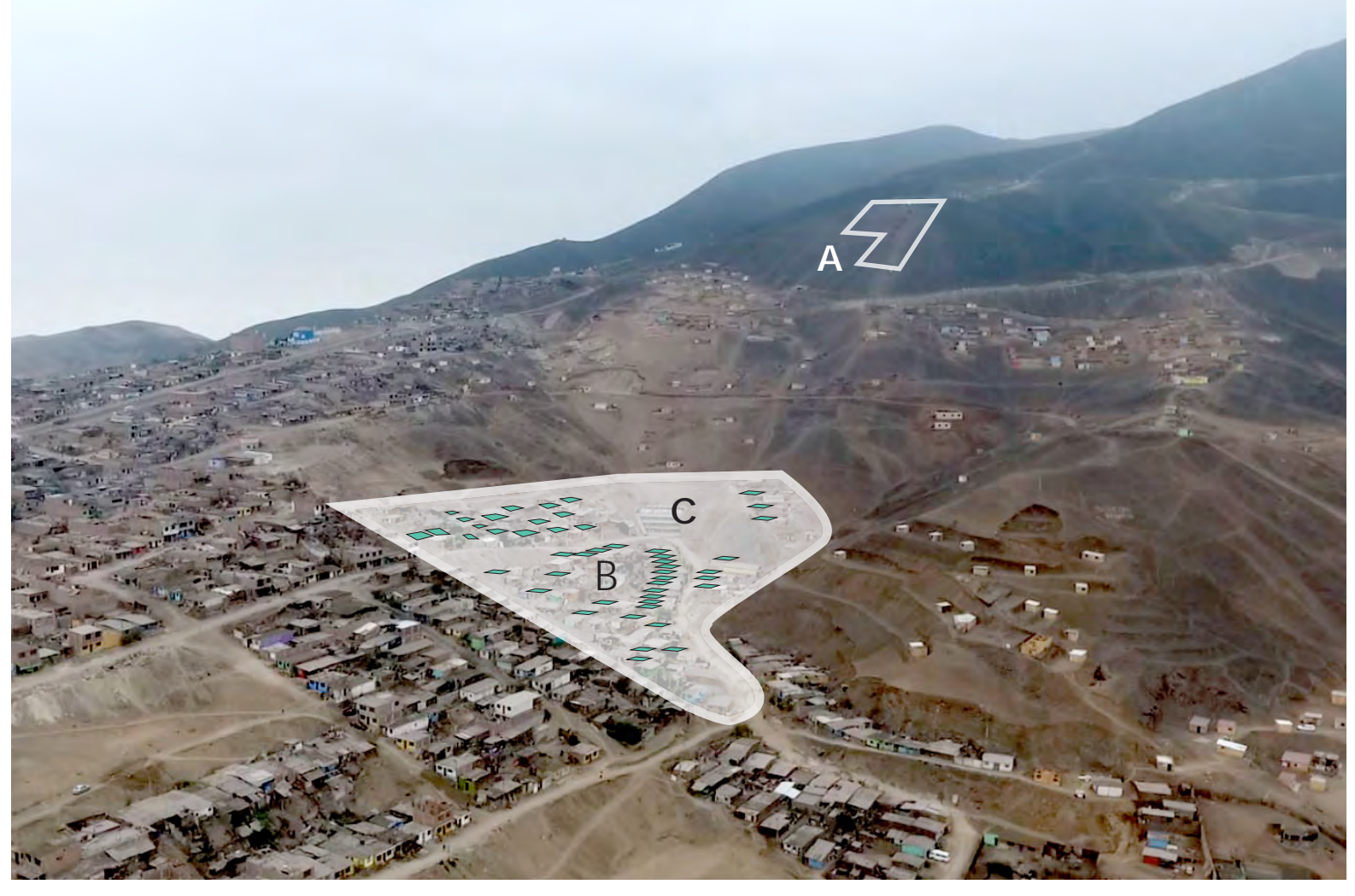

此
A. Fog Collection System
B. Household Gardens
C. Community Park

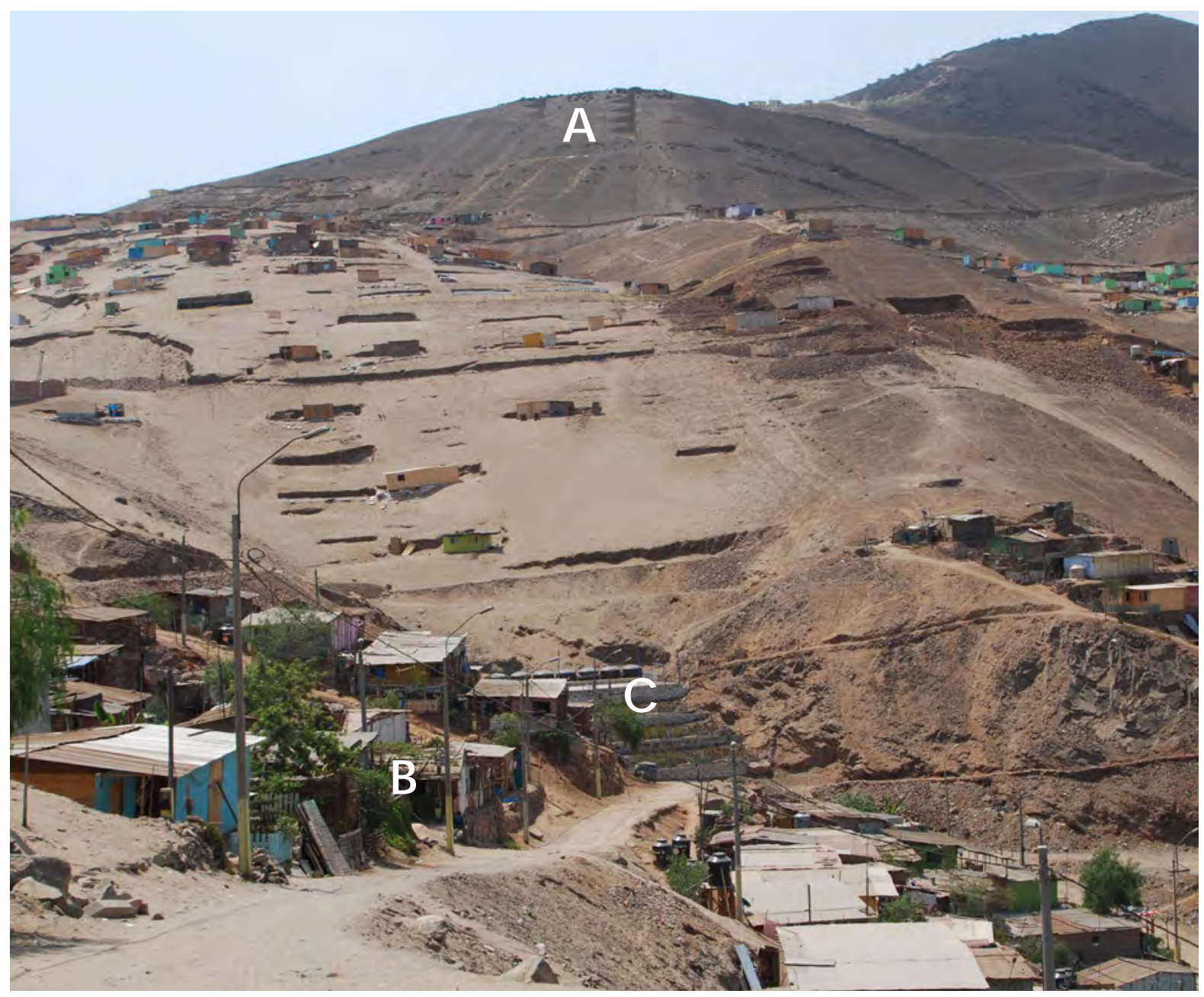

$\frac{U}{U}$
$\frac{1}{4}$
$\frac{1}{0}$
$\frac{1}{4}$ 

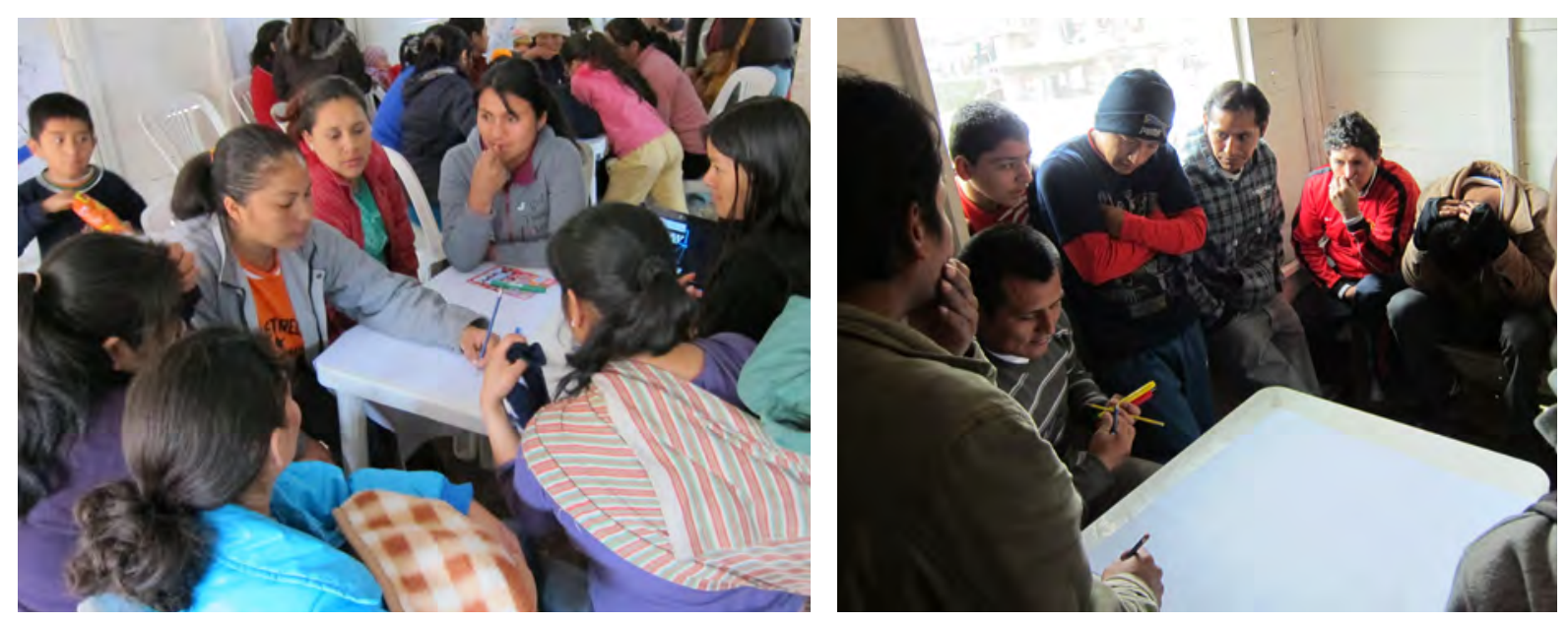

Fog Collection visioning workshop
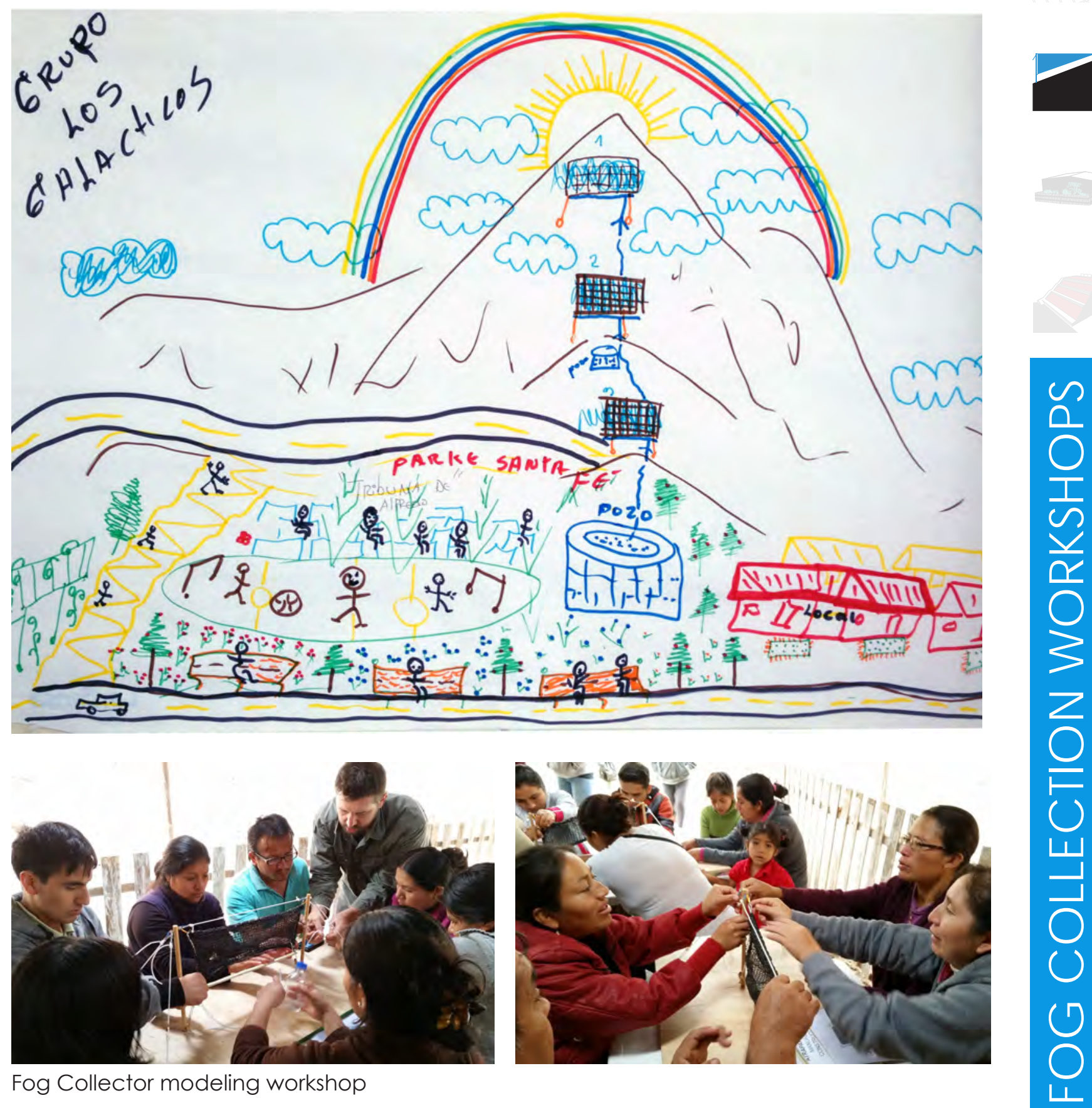

Fog Collector modeling workshop 


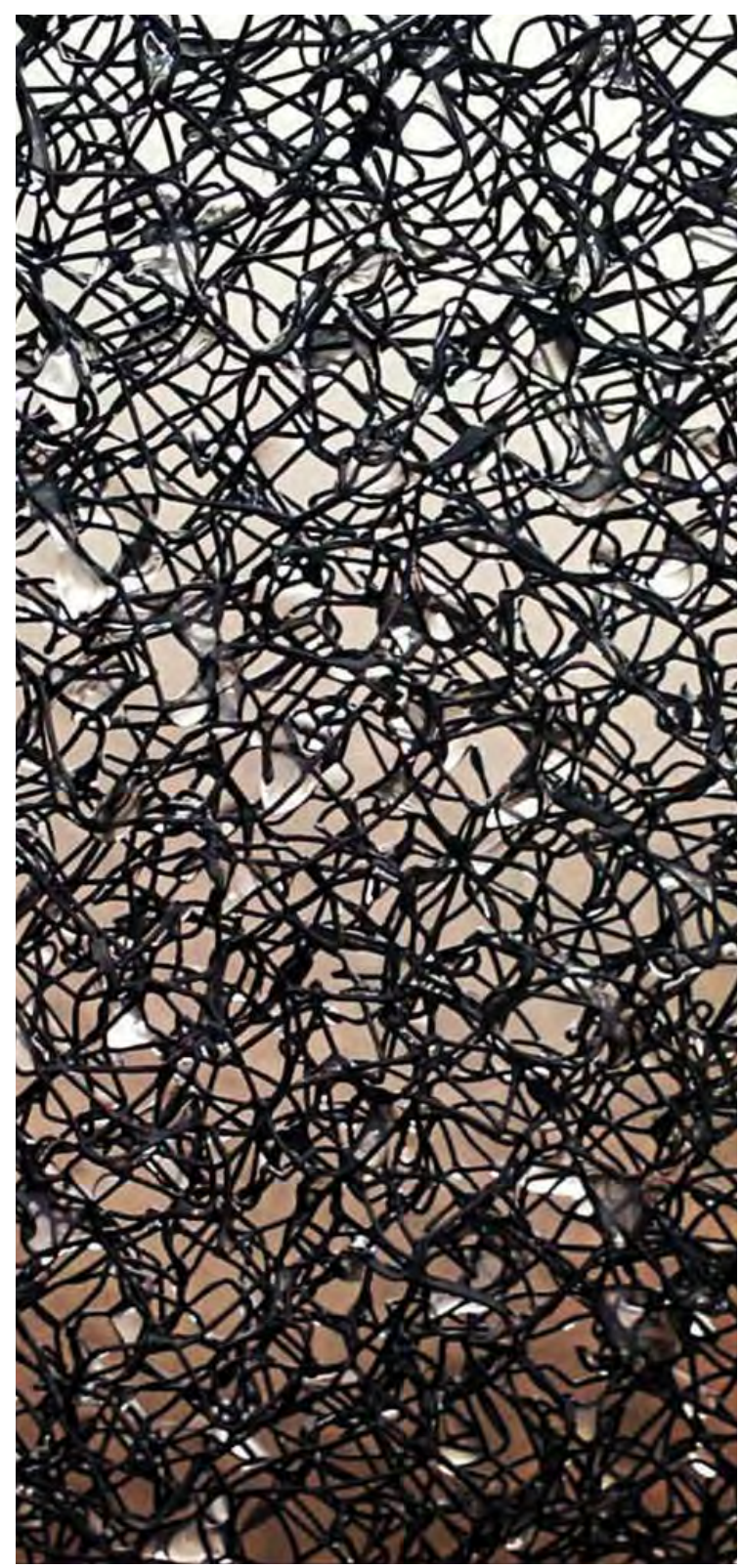

Improved Fog Collection Materials -

EnkaMat TRM 7010 and 7220
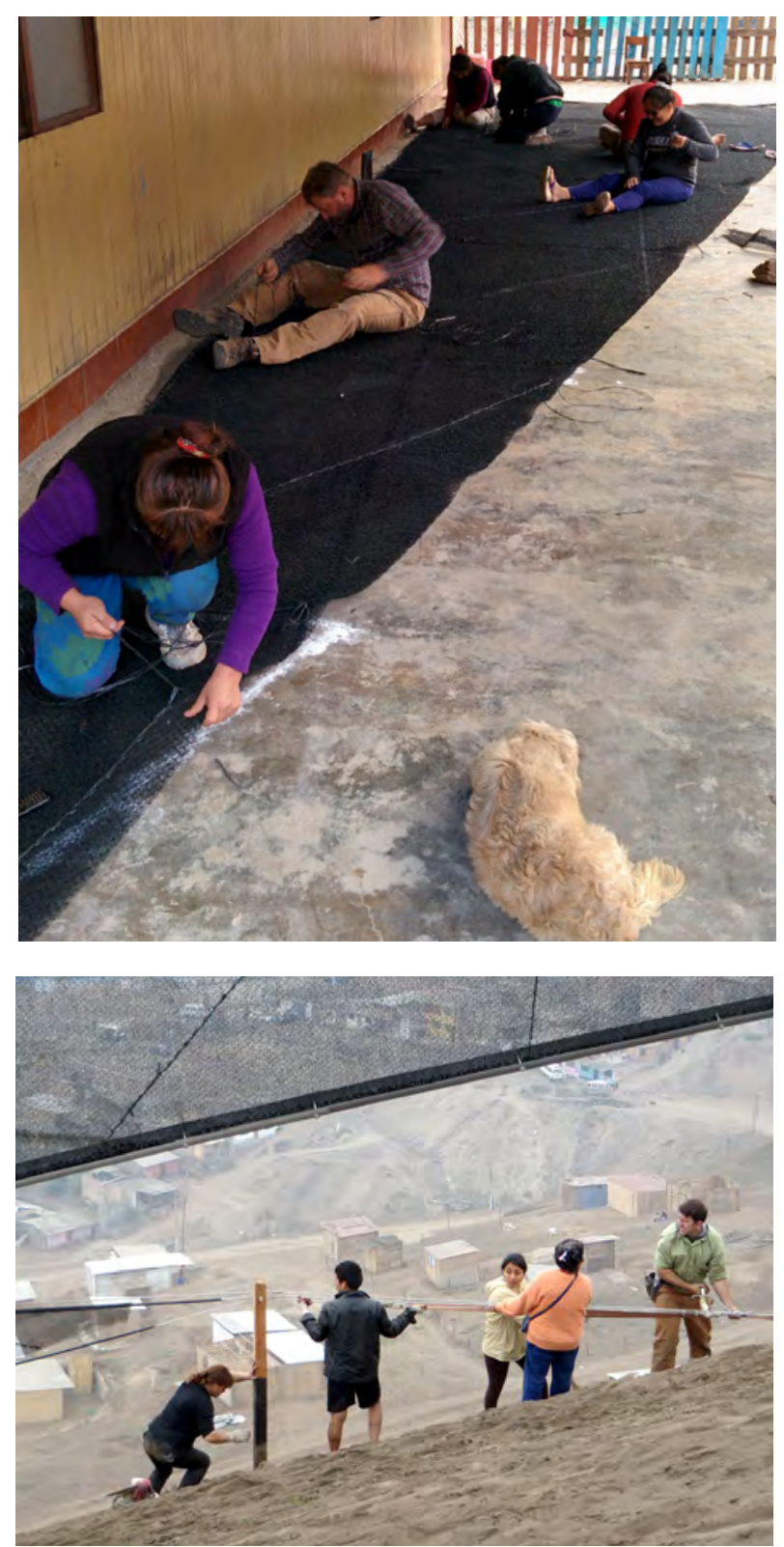

Community members constructed the fog collectors during particpatory work sessions

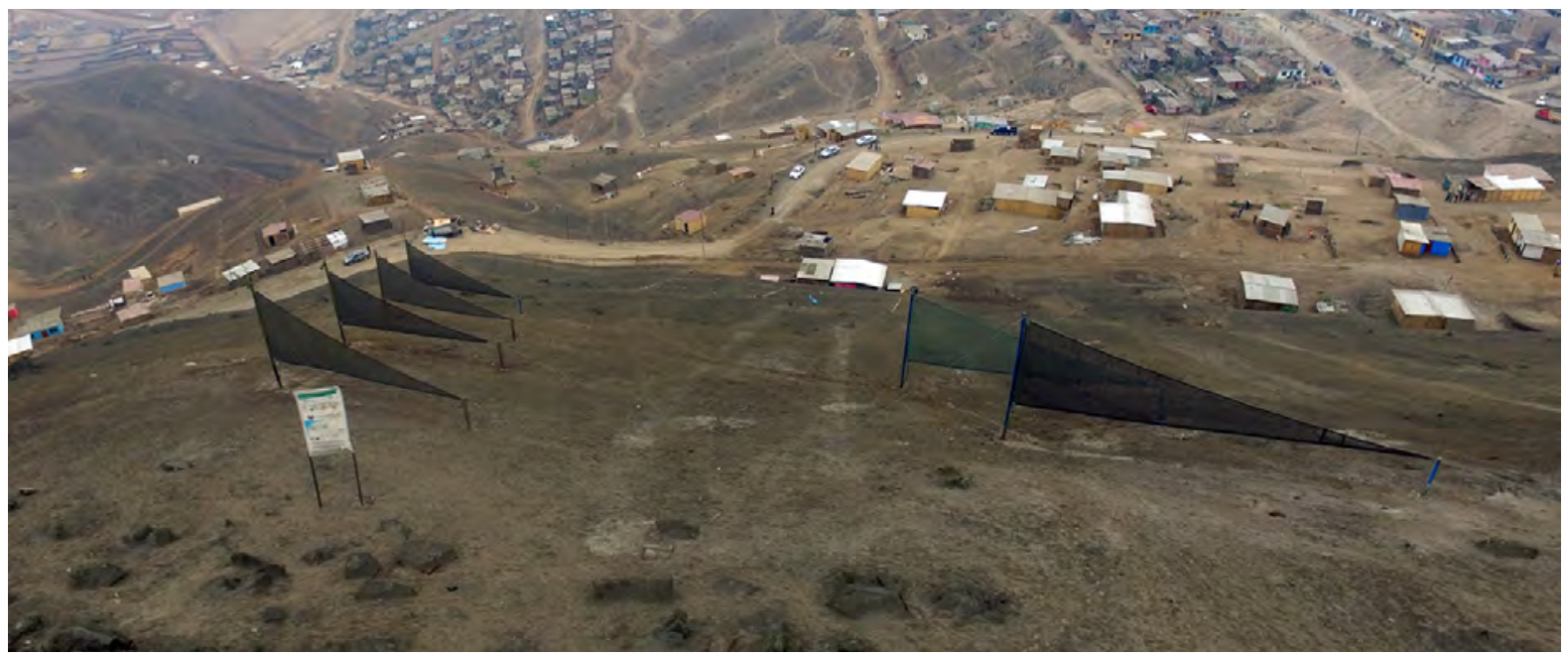

The complete fog collection system includes 6 triangular fog collectors with a combined $157 \mathrm{~m} 2$ of fog collection a rea 

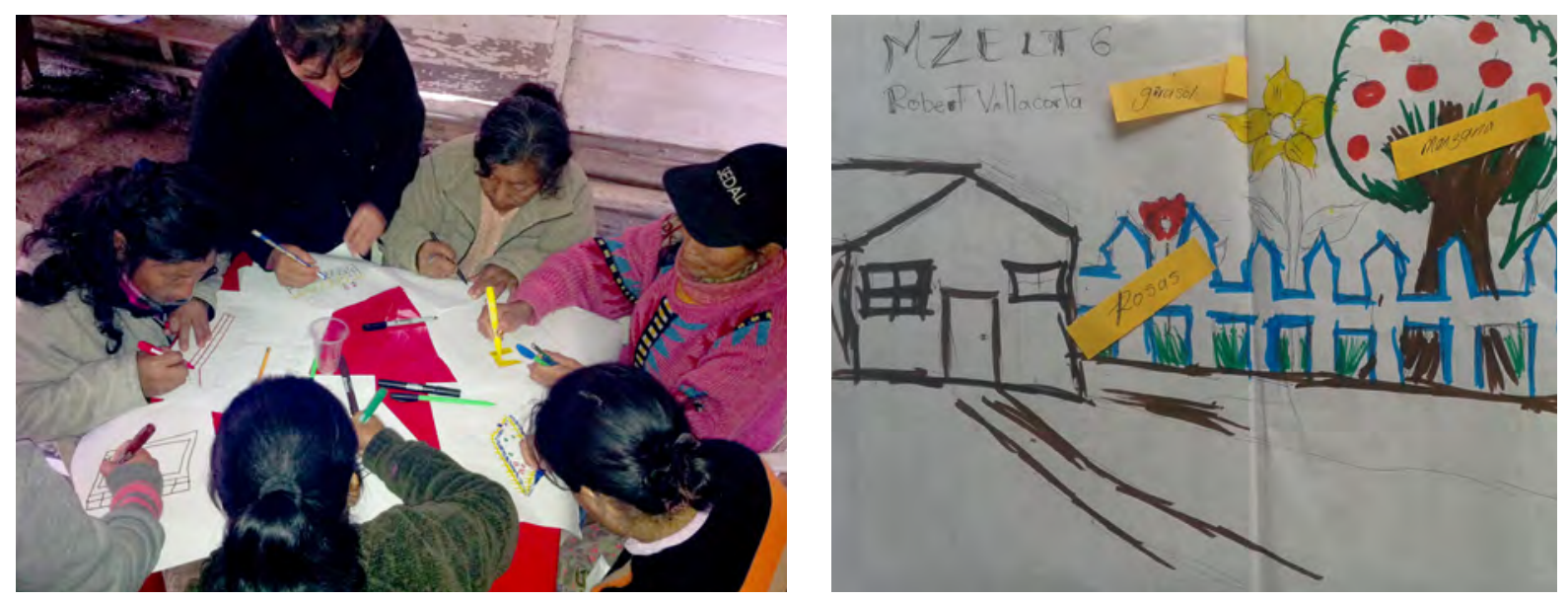

Participatory garden drawing workshop
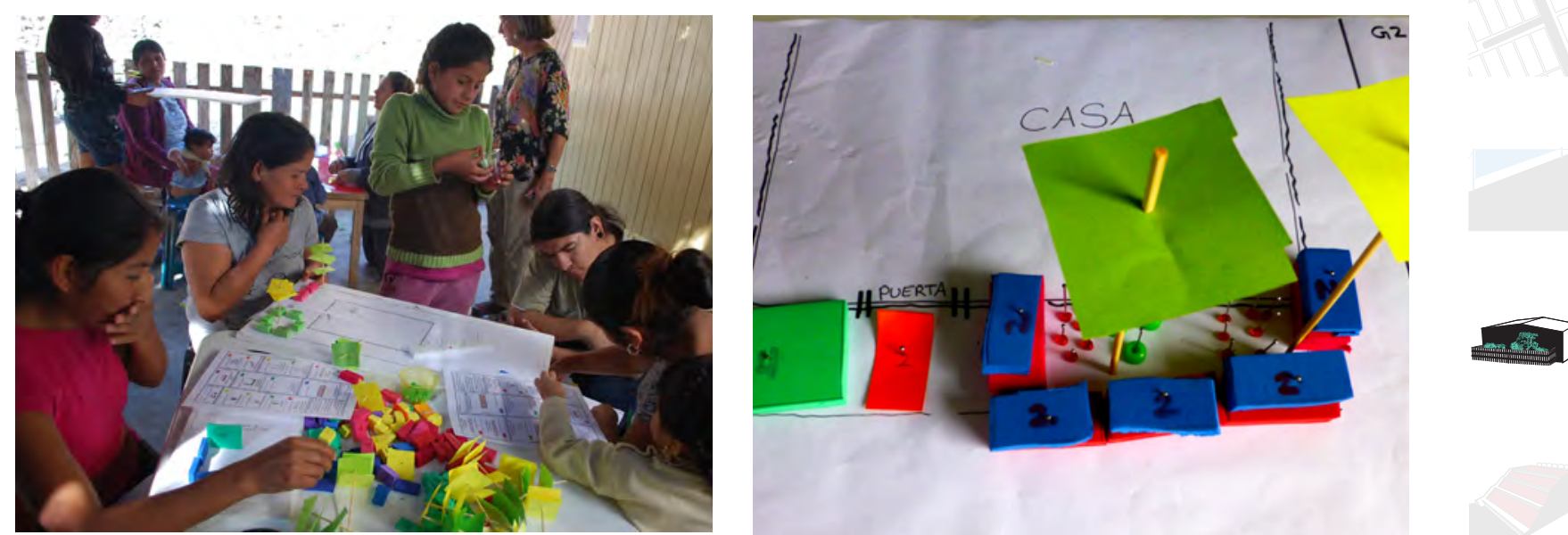

Partic ipa tory household garden modeling

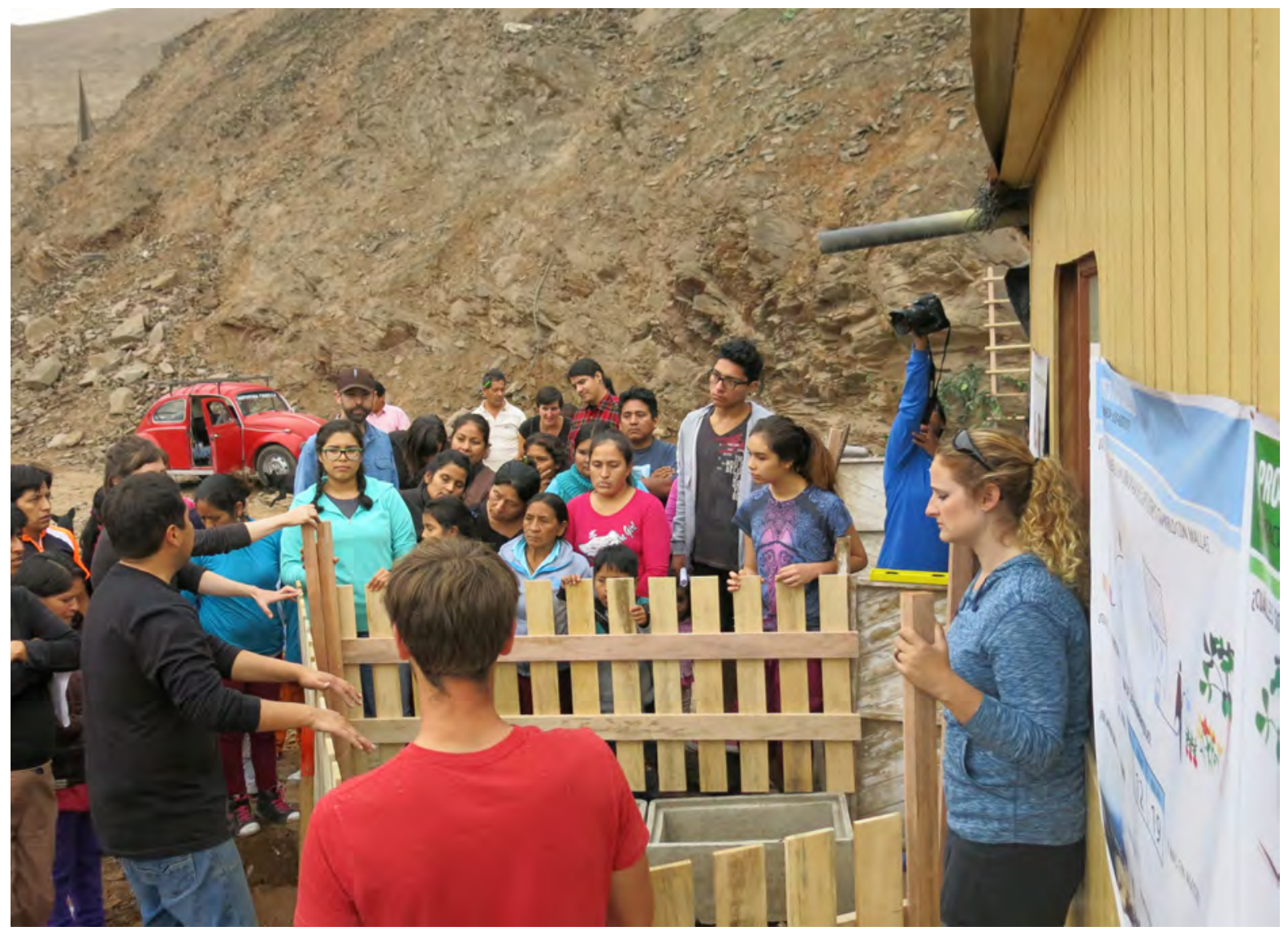




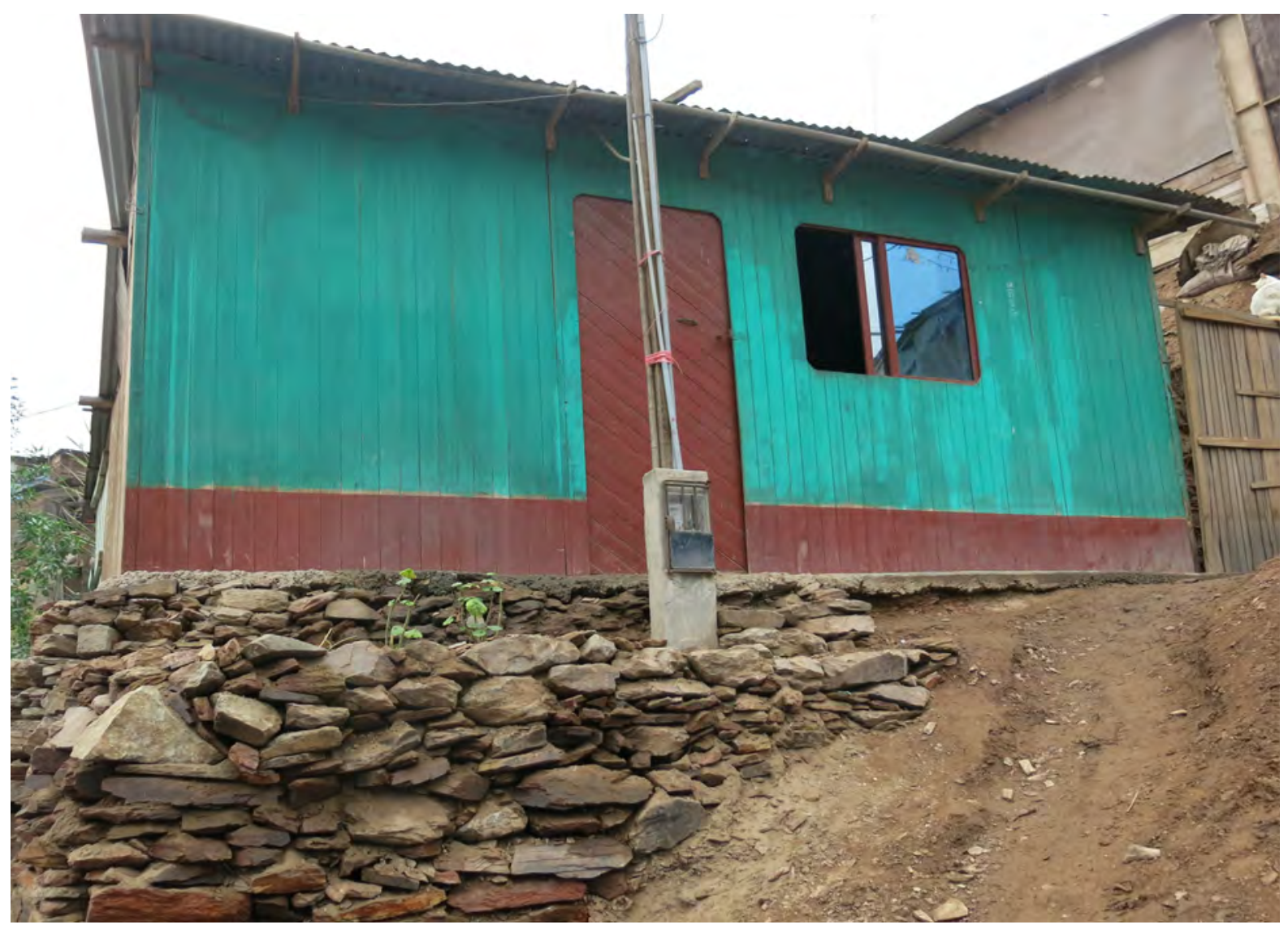

Before: July, 2015 w/o Garden (Lot G4)

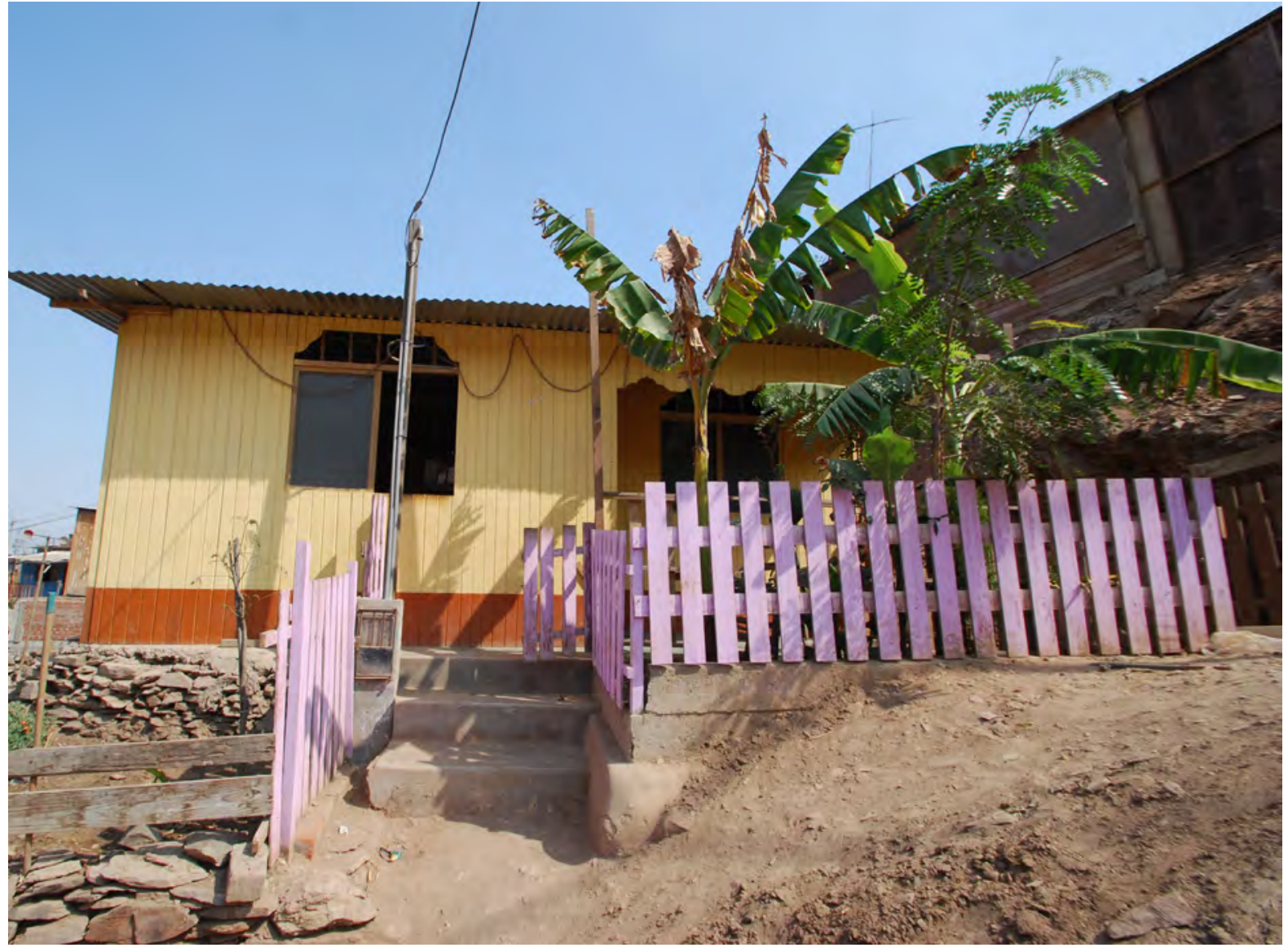

After: April 2017 w/ Garden (Lot G4) 

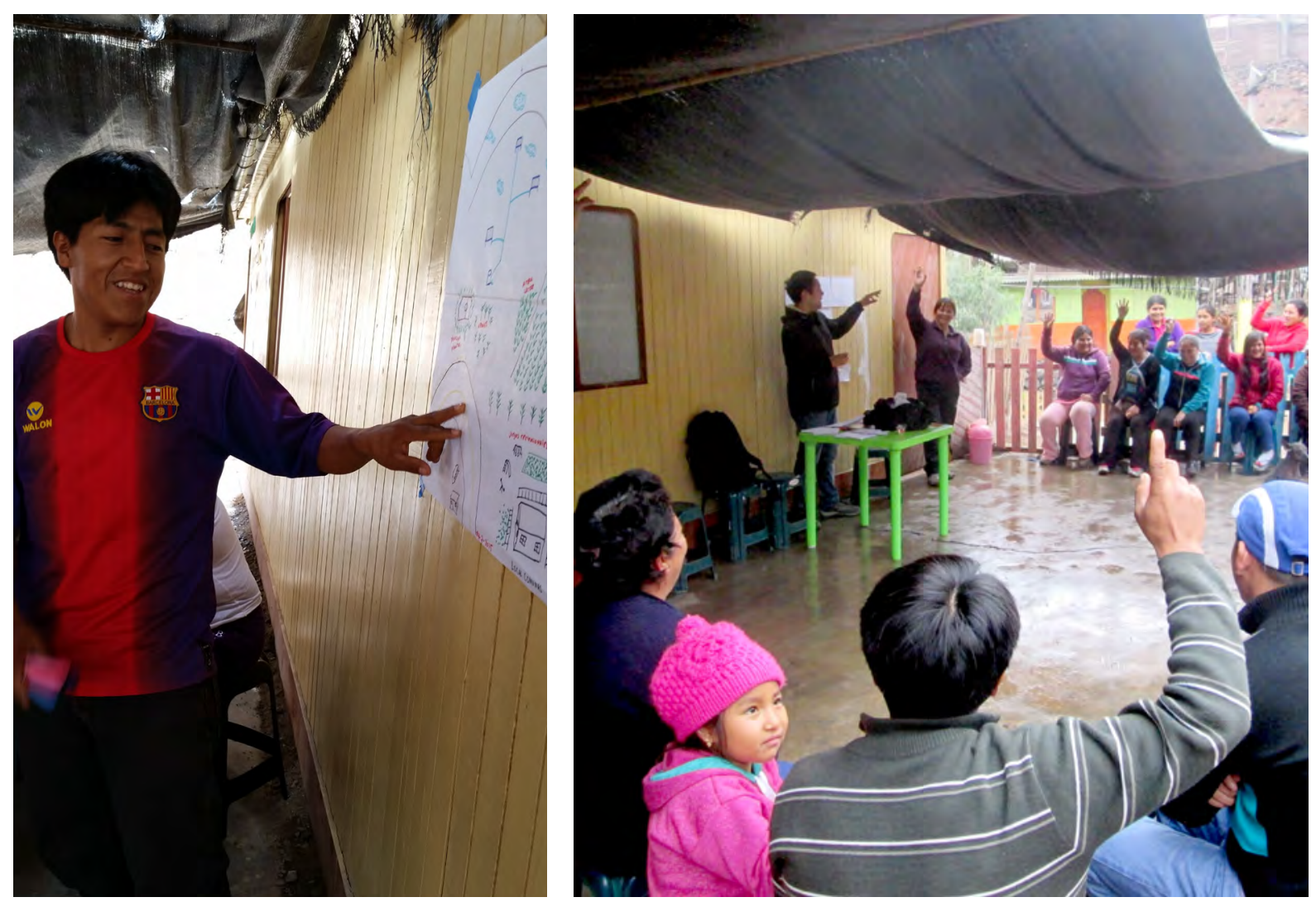

Community Park design workshops (pre-FWF project)
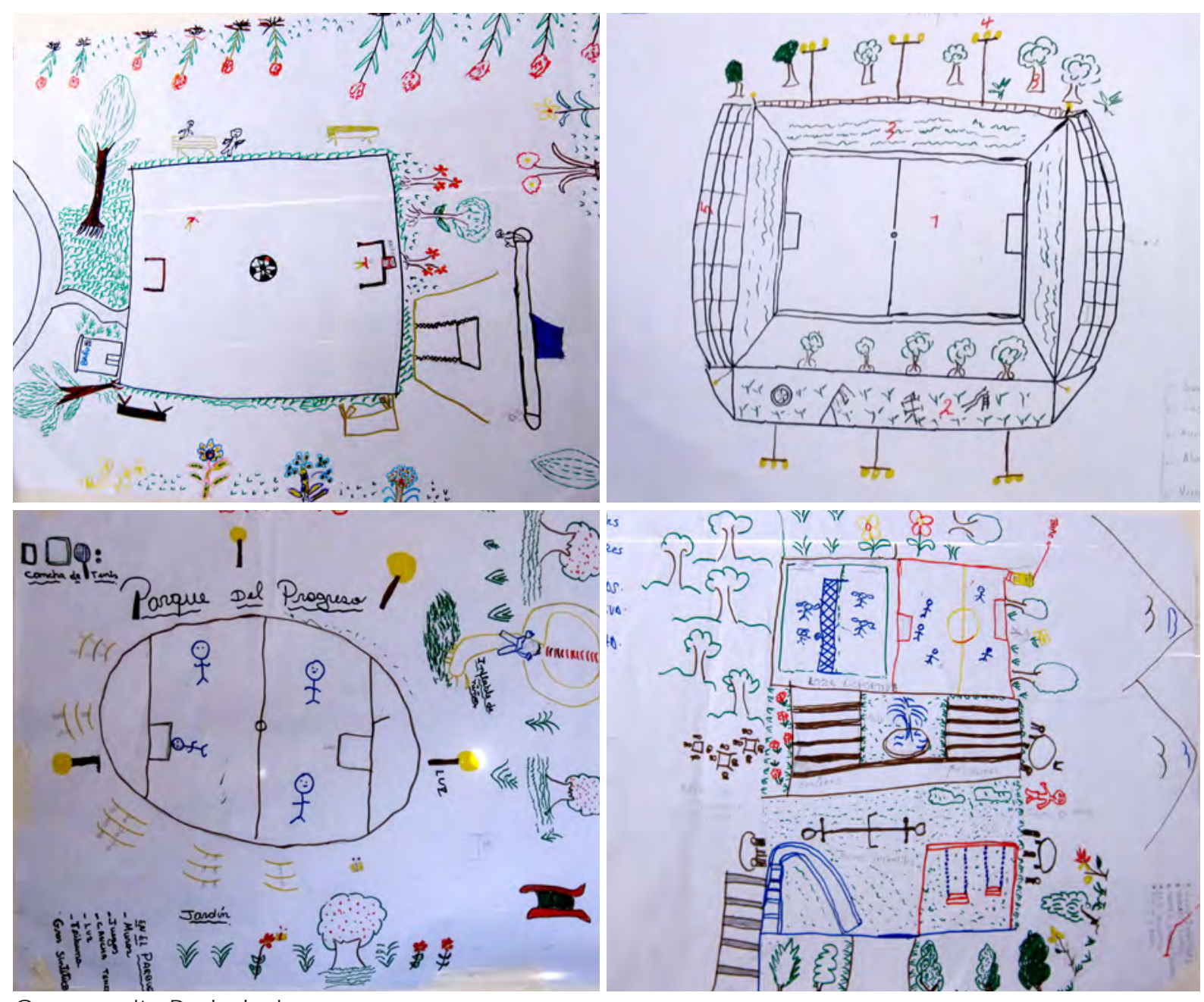


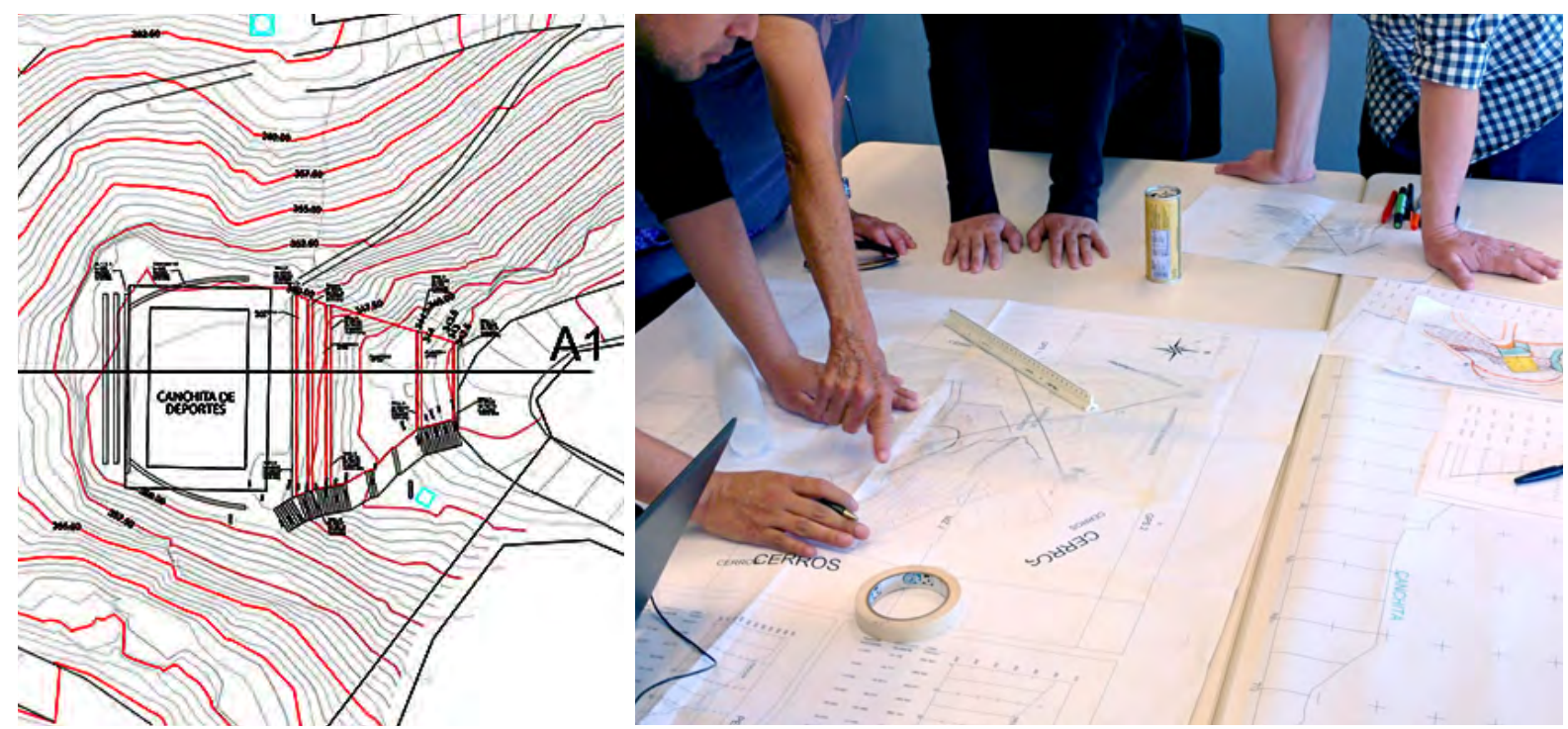

Topographic surveys and soil samples helped the AWB-S IUCI team make preliminary design decisions while working off site in Seattle.

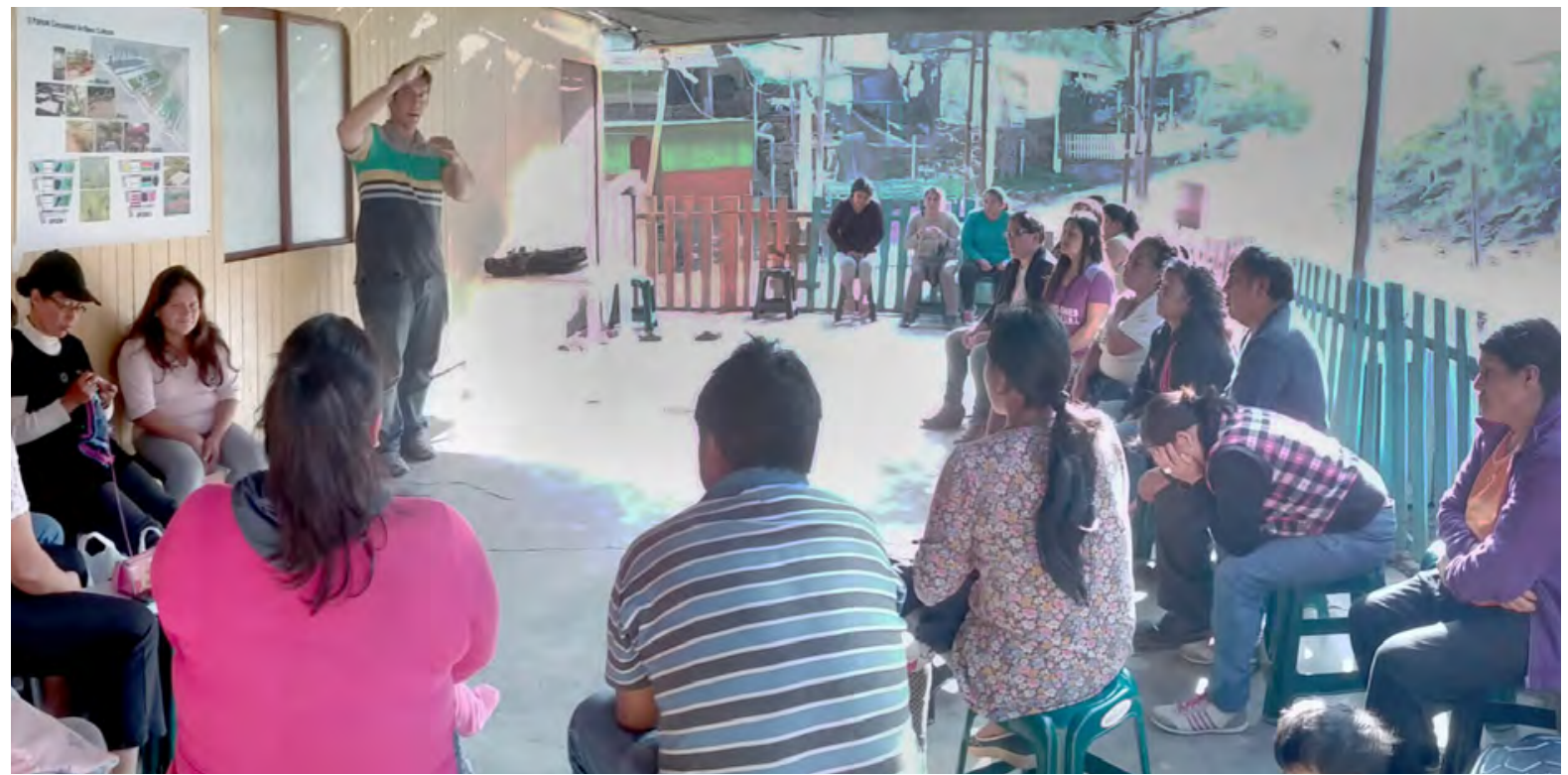

The park design was further refined on-site with frequent community participation

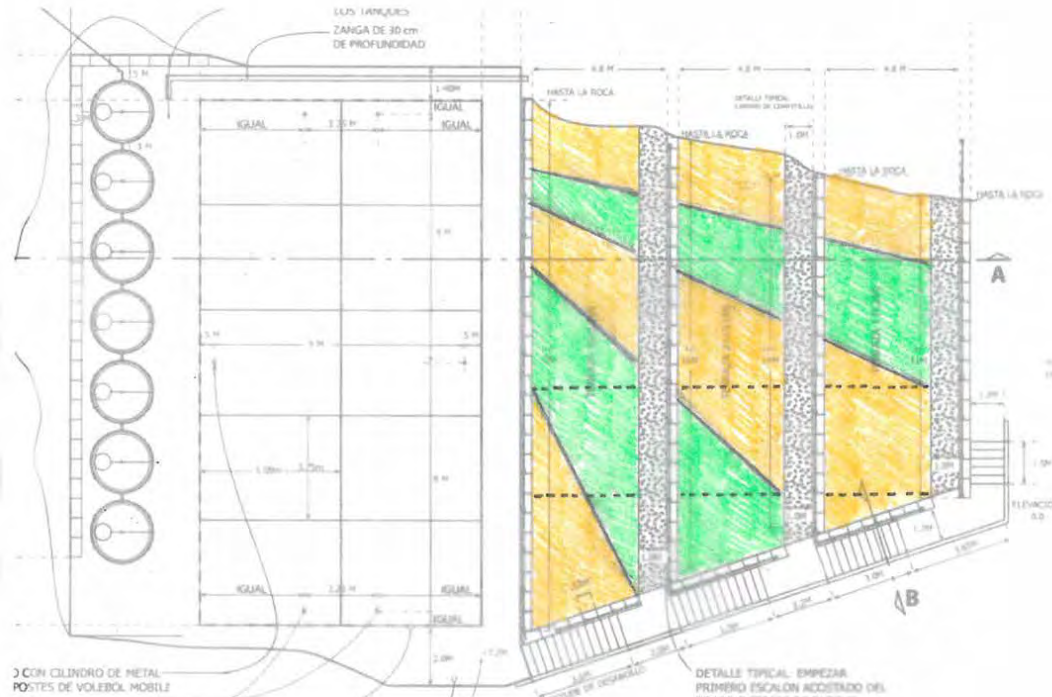

The final design includes a sports court, a stairway, three planted terraces and 35,000 liters of fog water storage for irrigation. 


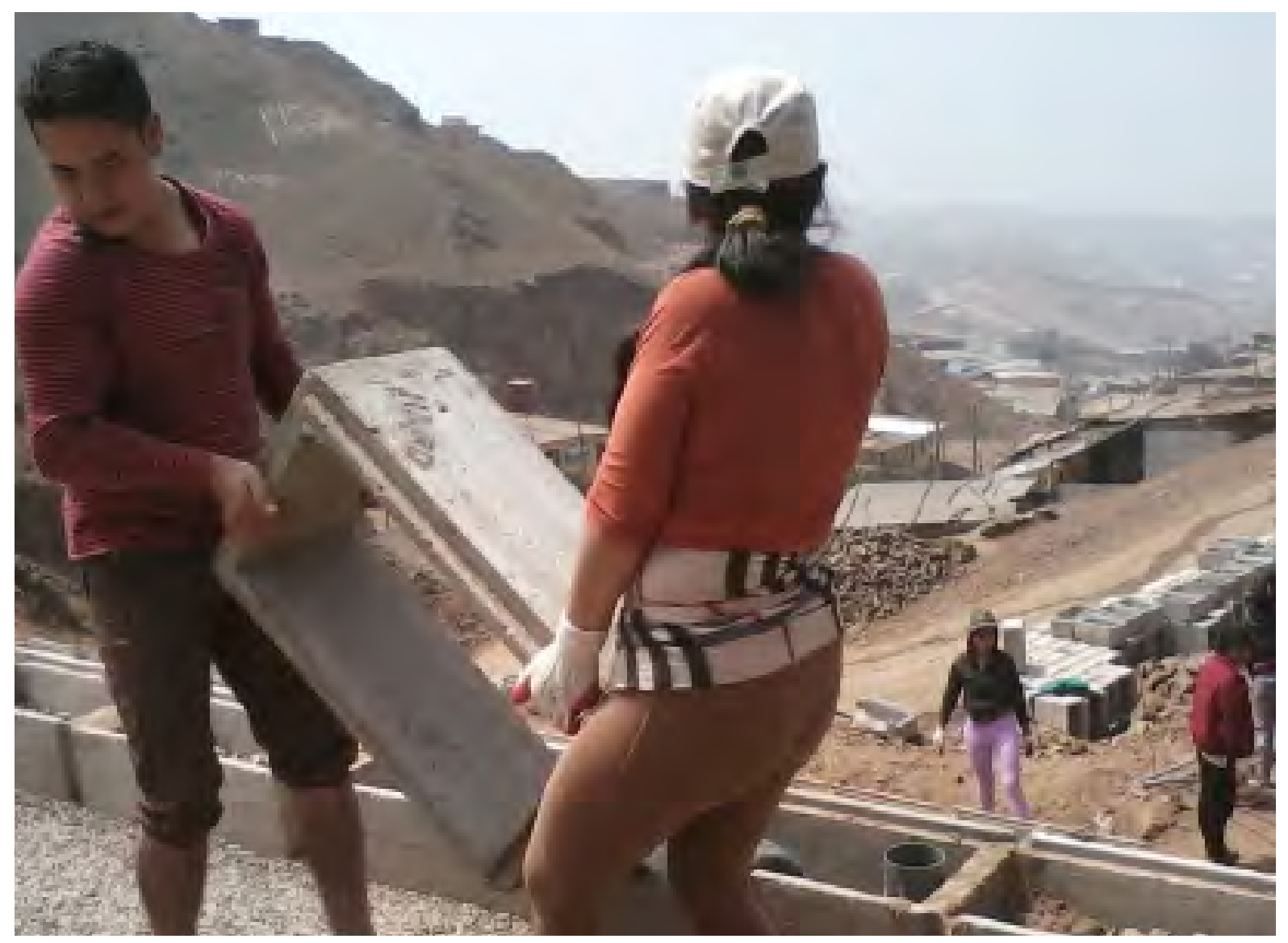

Modified precast water meter boxes were used as planters, benches and retaining walls

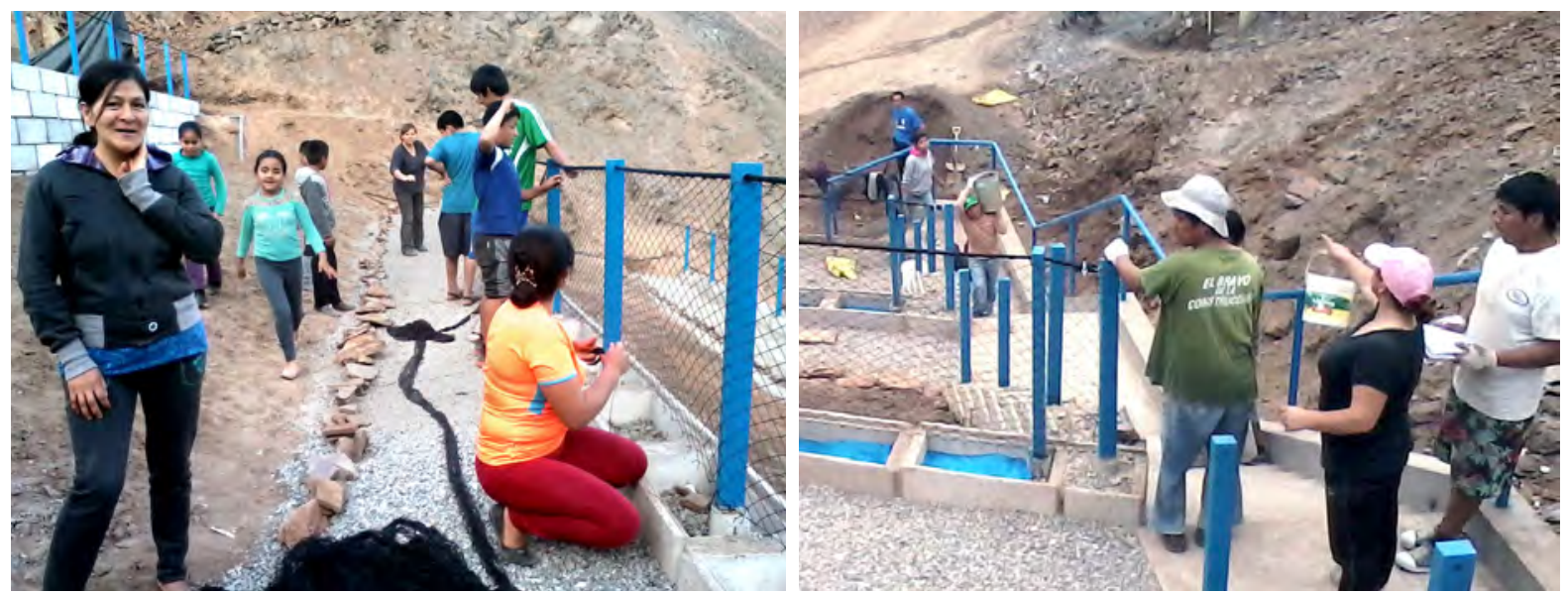

Fence construction
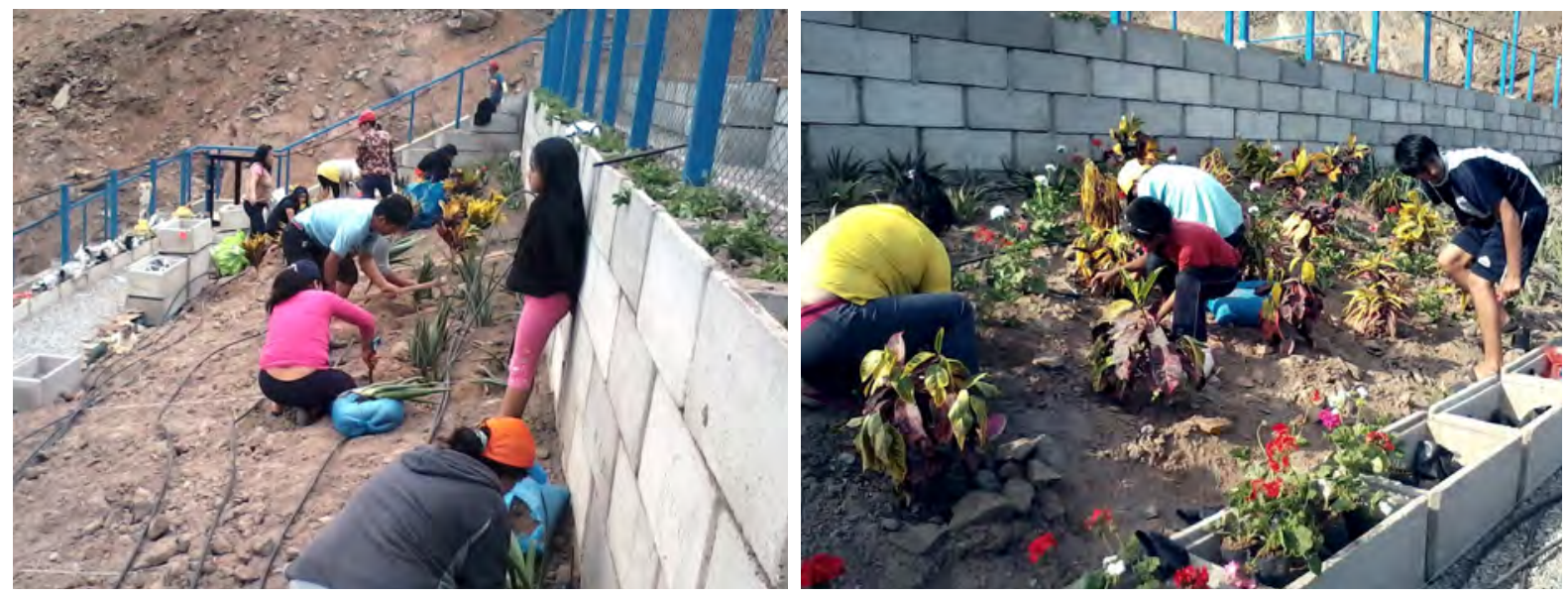

Community members planted over 1,300 plants

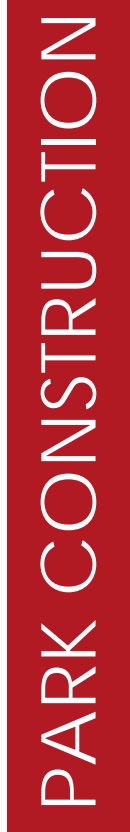



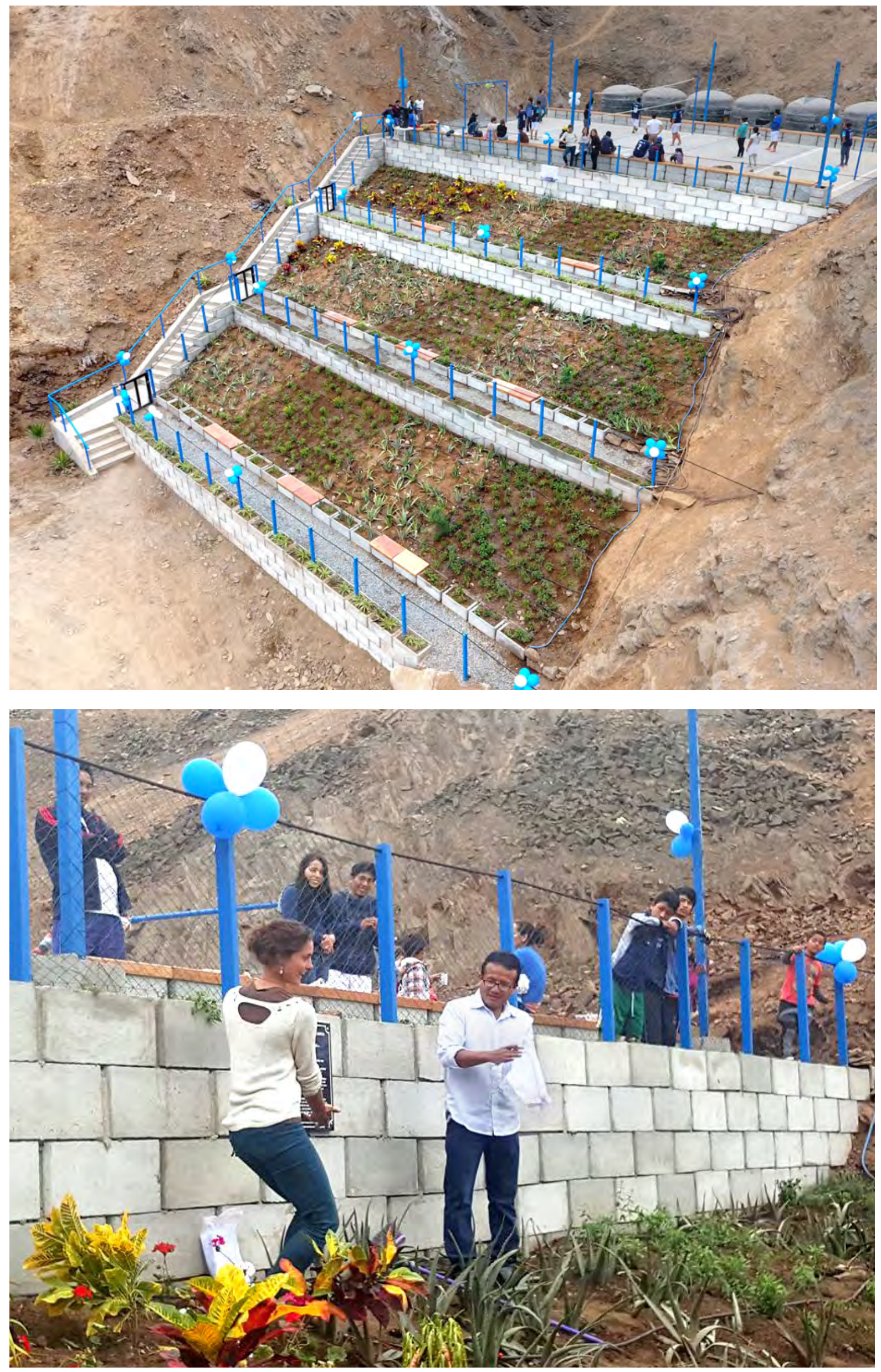

The park was inaugurated on October 23, 2016

$z$
0
$\frac{1}{\sigma}$
$\frac{1}{5}$
$\frac{1}{3}$
$\frac{1}{Z}$
$\frac{1}{\alpha}$
$\frac{1}{\alpha}$



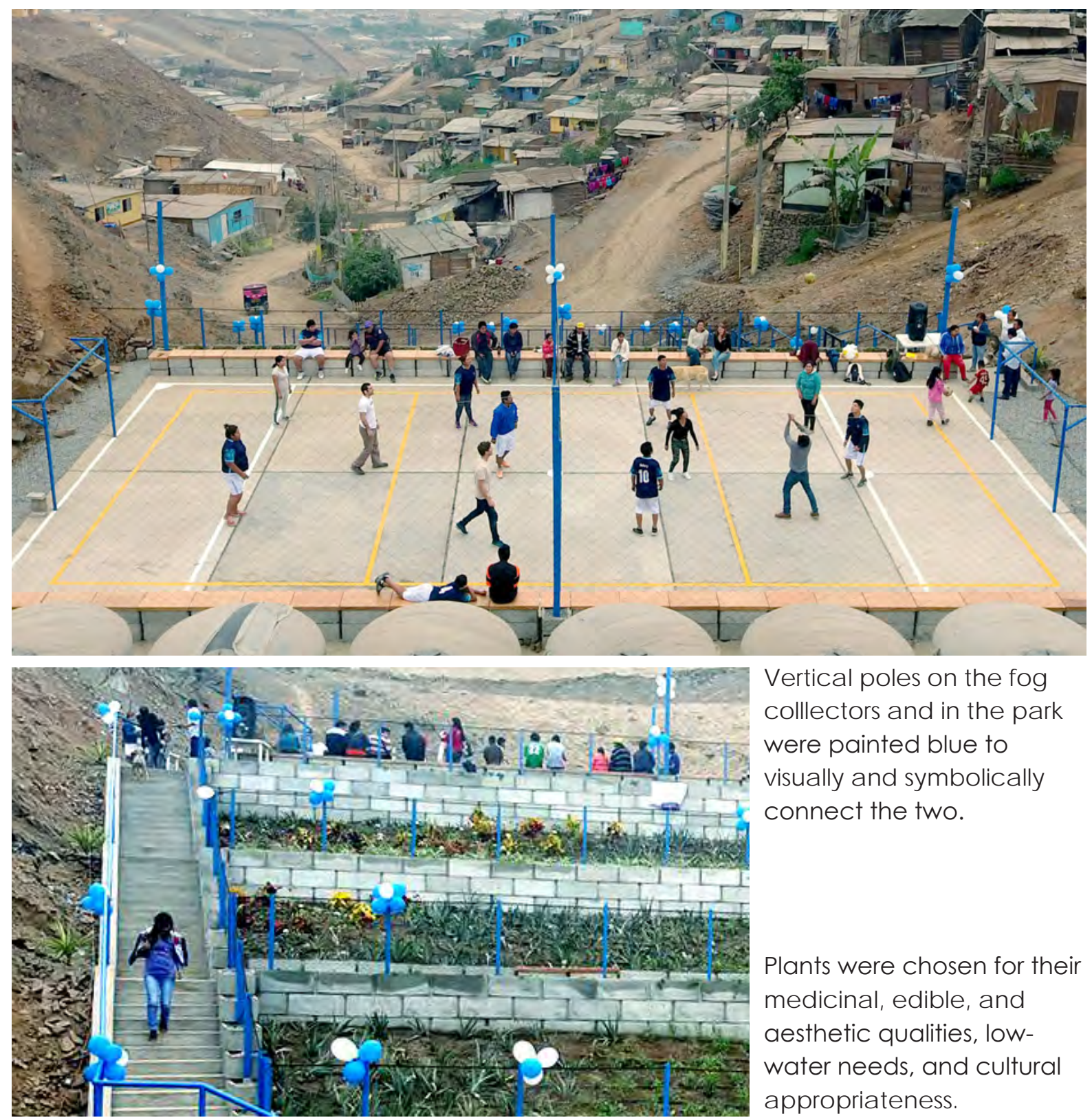

Vertical poles on the fog collectors and in the park were painted blue to visua lly a nd symbolic a lly connect the two.

Plants were chosen for their medic inal, edible, and aesthetic qualities, lowwater needs, and cultural appropriateness.
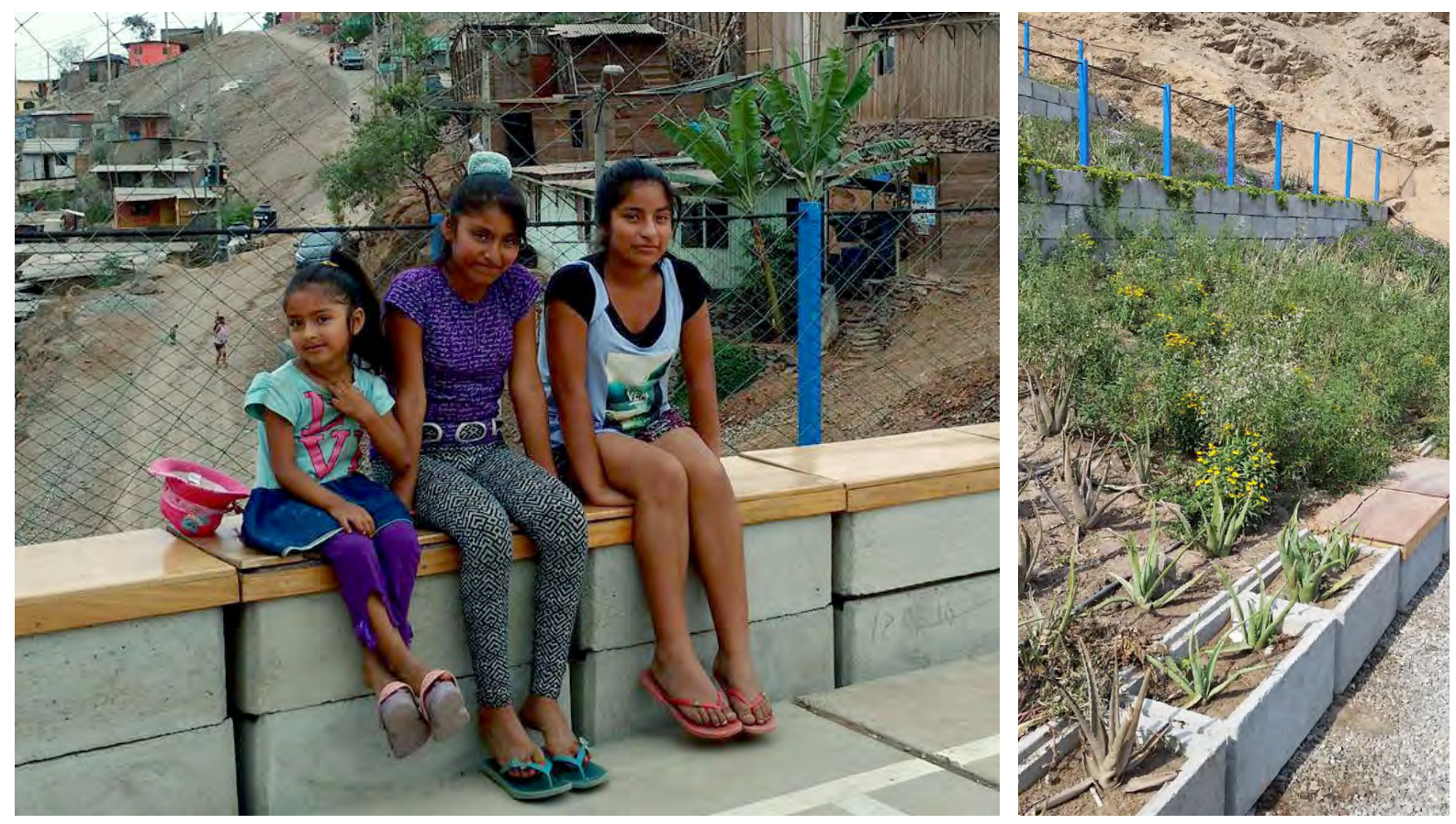

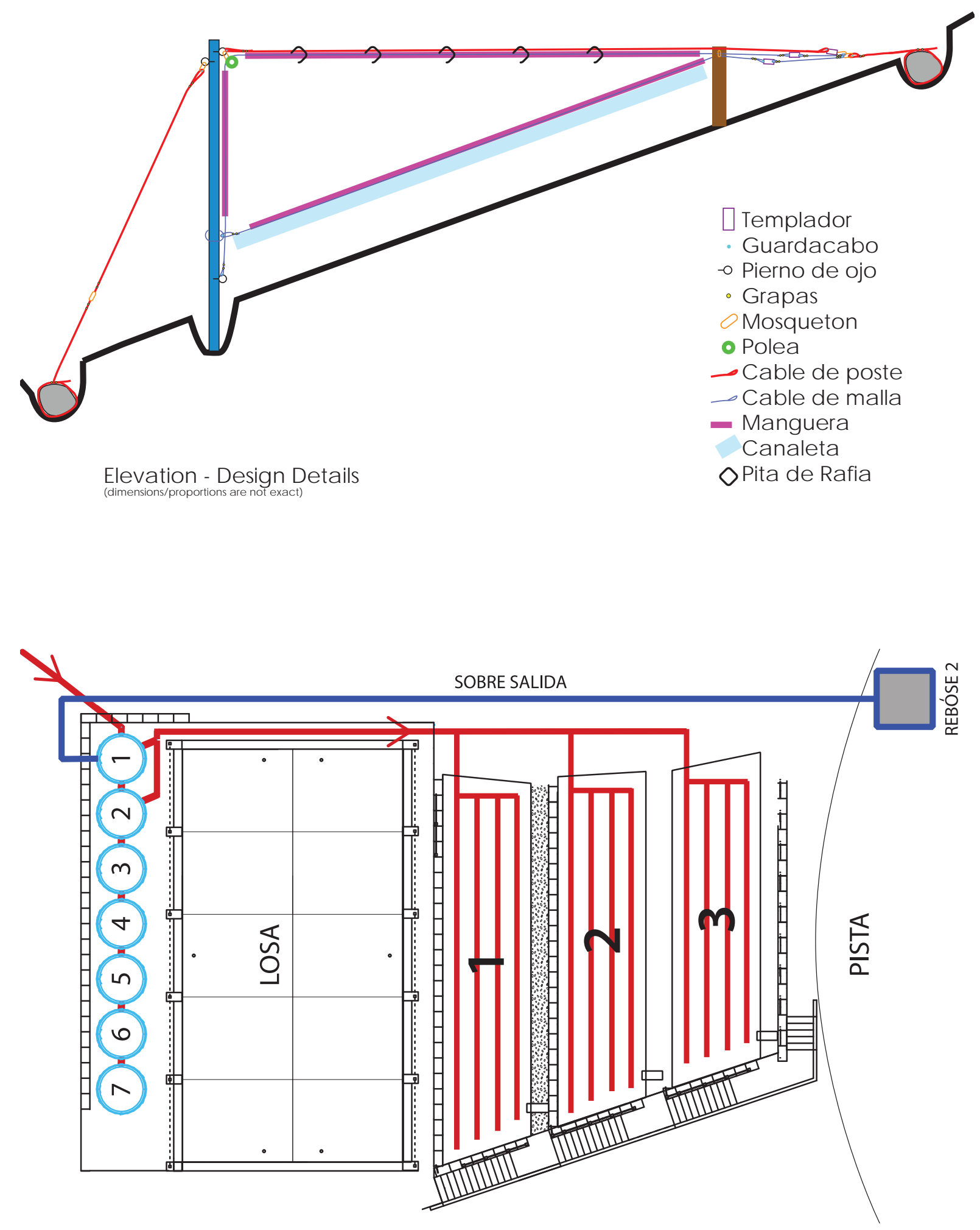

The longevity of the Fog Water Farms project depends on the community's dedication to its maintenance. To assist community members, the project team prepared several manuals with illustrated photos and diagrams on system components, crucial maintenance tasks, and problem solving tips.

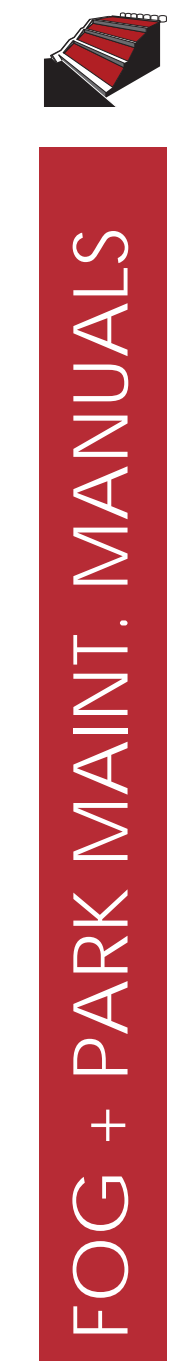



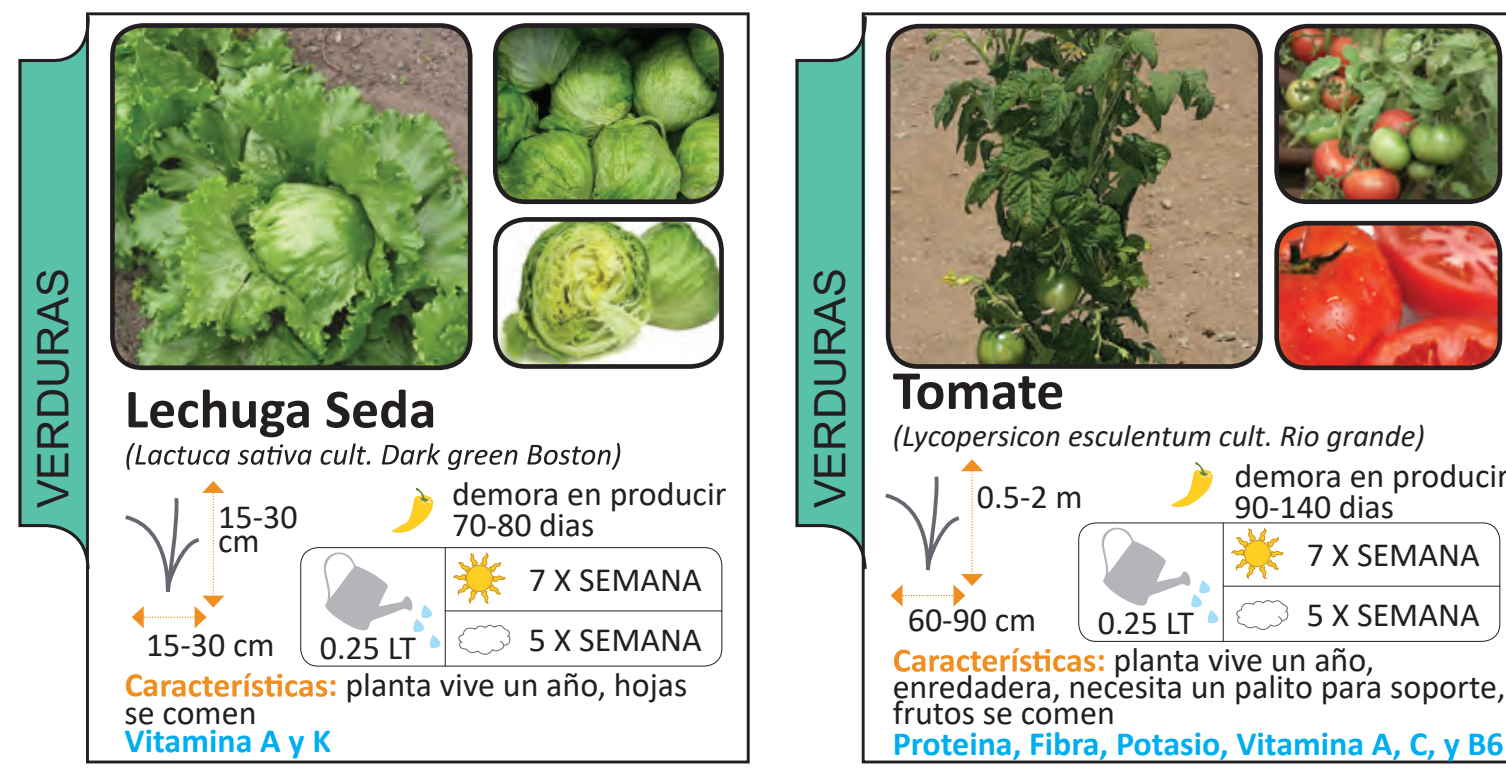

(Lactuca sativa cult. Dark green Boston)

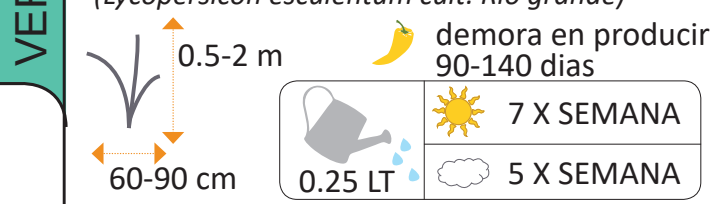

Características: planta vive un año,

enredadera, necesita un palito para soporte, frutos se comen

Proteina, Fibra, Potasio, Vitamina A, C, y B6
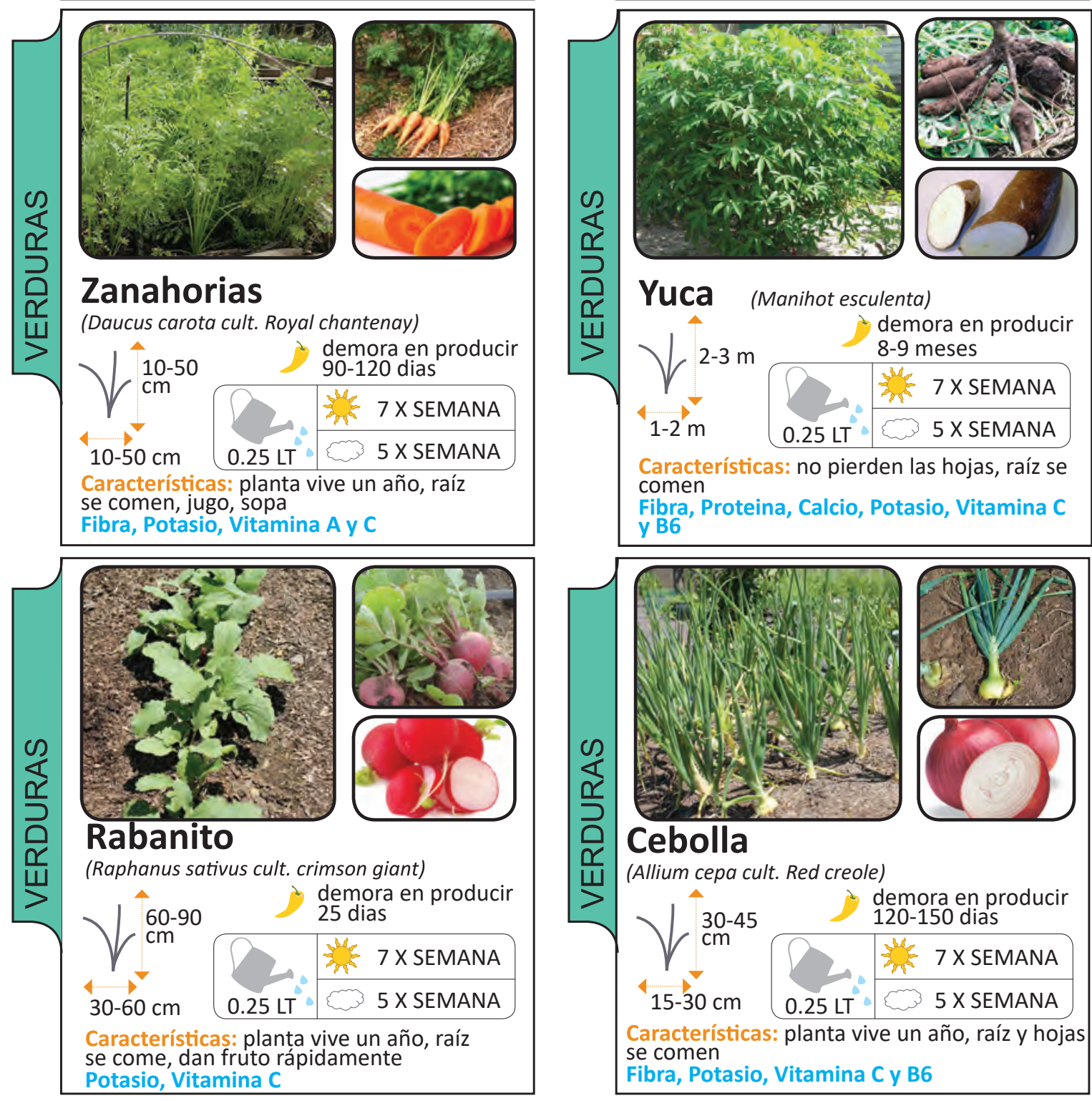

Each household participating in the household garden project received a ma intenance manual to assist them in planting and caring for their gardens. 

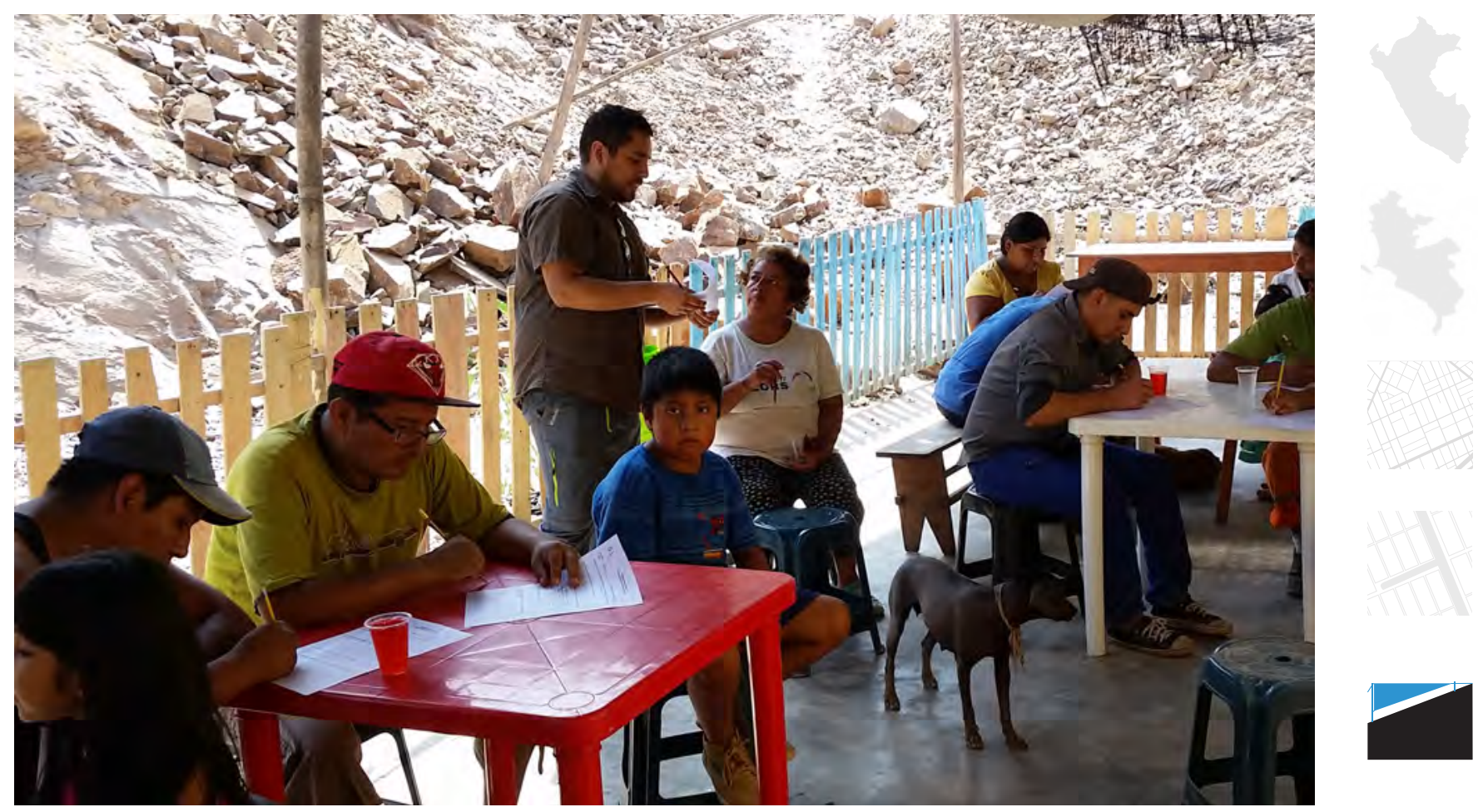

Pa rtic ipa tory Impact Assessment exc erc ises ind ic a te positive outcomes rang ing from improved water security to enhanced quality of life.
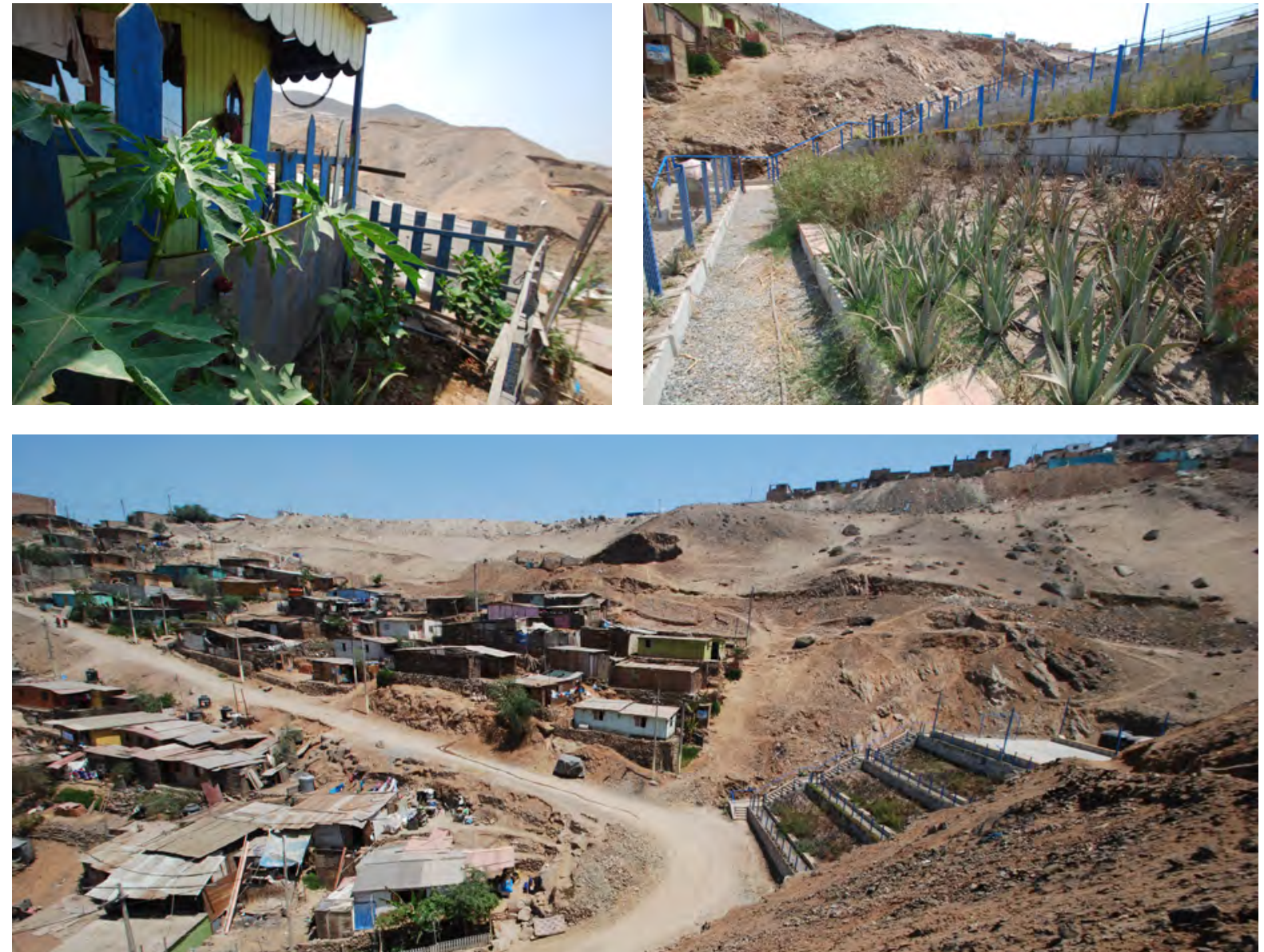

Despite significant challenges following project implementation including a two week period without water, the fog collection system, gardens and park remain in good condition. EC residents are investing their time and resources to assure the Fog Water Farms project continues to benefit the community. 
"We need water storage to ma inta in the gardens because they are the lungs of human beings"

"[The community] is more organized and we have an excellent view. It is very satisfying for the whole community. The park is very cool."

"It has changed my life because I love sports. I am happy to have a sports field decorated with plants in my community. It makes all my weekends happy and fun."

"I like most the park, because we can go to water the plants and distract ourselves while our children can play there."

"When I have problems I go to the park and forget about them"

"[The park] provides a big change. It beautified the community. Now we have a healthy environment where our children can play.

"The people [in our community] a re committed to taking care of the sportsfield and plants, because the plants are the a ir of our lives"

"it is beautiful what the projects have done in the community"

"The quality of life always gets better with a park inside the community"

"Seeing the flowers bloom, when the seeds are growing, the colors and shapes of plants. It is very rewarding to be part of that."

"I only want to say thank you for bringing happiness to our home. Thank you."

"Thank God for bringing you to Eliseo Collazosand changing us and our fa milies' life. Thank you very much." 


\section{Project Images}

Appendix 8: Example of Household Garden Evolution 2013-2020 
Example of Household Garden Evolution in Eliseo Collazos 2013 - 2020
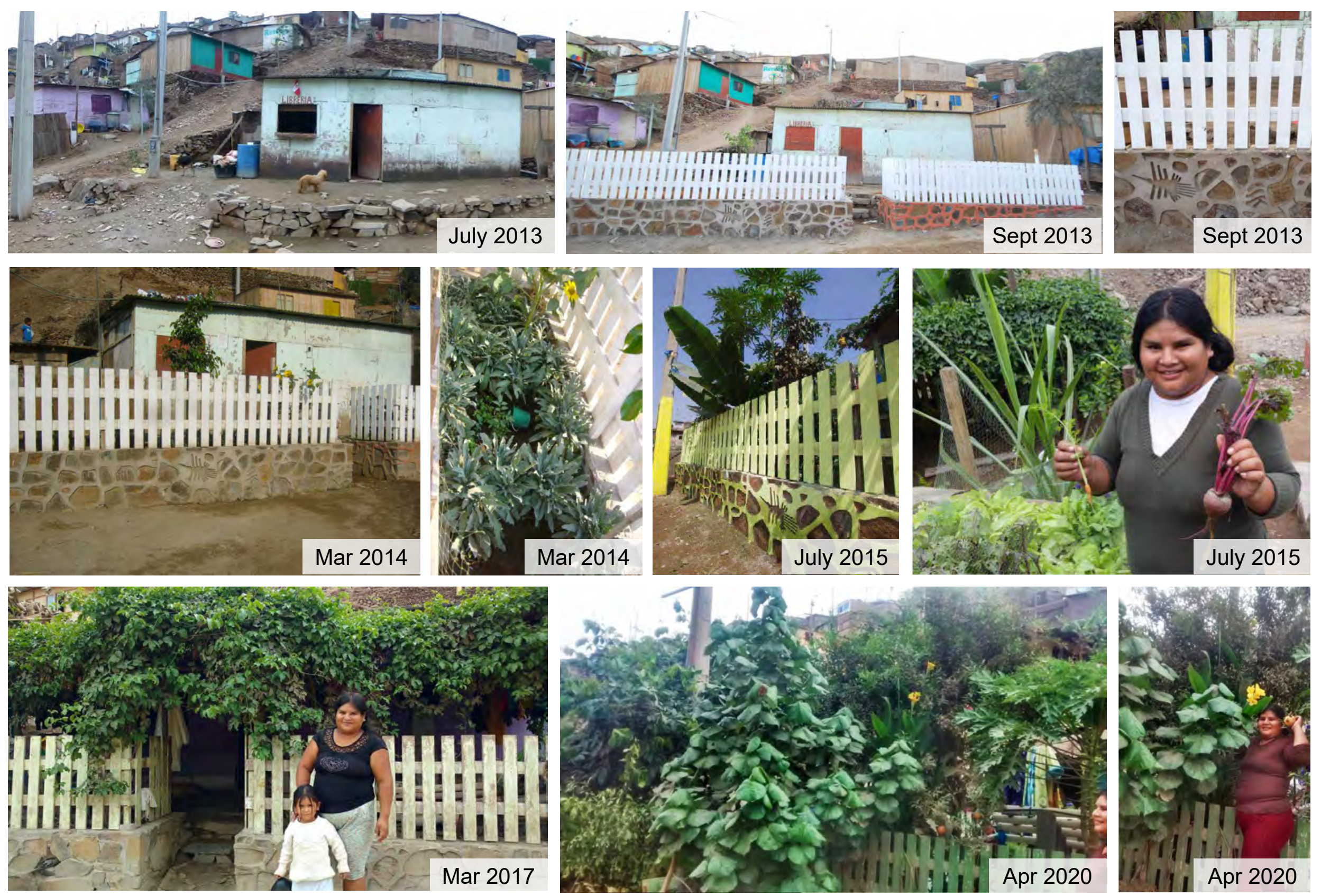